Universidade de São Paulo

Faculdade de Arquitetura e Urbanismo

Carlos Eduardo Murgel Miller

\title{
Reurbanização do Vale do Anhangabaú: propostas para a recriação de uma paisagem
}

São Paulo 



\section{Reurbanização do Vale do Anhangabaú:}

\section{propostas para a recriação de uma paisagem}

Carlos Eduardo Murgel Miller

Orientador Professor Doutor Eugenio Fernandes Queiroga

Dissertação de mestrado

Área de concentração | Paisagem e Ambiente

Linha de pesquisa | Paisagem e Sociedade

Universidade de São Paulo

Faculdade de Arquitetura e Urbanismo

São Paulo, fevereiro de 2017 

Autorizo a reprodução e divulgação total ou parcial deste trabalho, por qualquer meio convencional ou eletrônico, para fins de estudo e pesquisa, desde que citada a fonte.

Catalogação na Publicação

Serviço Técnico de Biblioteca

Faculdade de Arquitetura e Urbanismo da Universidade de São Paulo

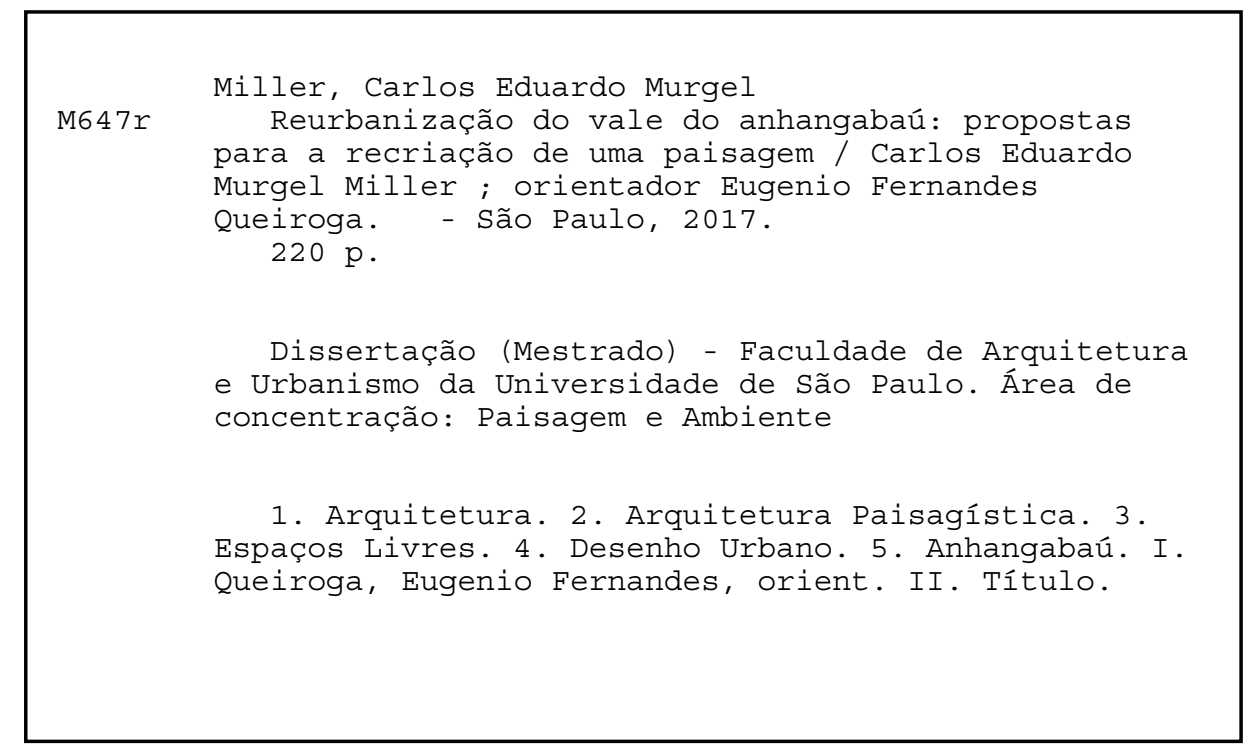





\section{Ficha de Aprovação}

\section{Reurbanização do Vale do Anhangabaú:}

propostas para a recriação de uma paisagem

Carlos Eduardo Murgel Miller

Orientador Professor Doutor Eugenio Fernandes Queiroga

Dissertação de mestrado

Área de concentração | Paisagem e Ambiente

Linha de pesquisa | Paisagem e Sociedade

Universidade de São Paulo

Faculdade de Arquitetura e Urbanismo

Aprovado em de de 2017

\section{Banca Examinadora}

Prof ${ }^{\circ}$ Dr. Eugenio Queiroga - FAUUSP 

Reurbanização do Vale do Anhangabaú:

propostas para a recriação de uma paisagem 

À dedicação de uma vida inteira de meus pais, à confiança inabalável de uma irmã e ao amor de uma mulher.

À memória de meu tio. 



\section{Agradecimentos}

A concretização deste percurso deve-se ao trabalho e a confiança de muitos professores, os quais de diferentes formas contribuíram com minha formação não só nos últimos anos, mas desde muito tempo. Não poderia deixar de lembrar aqui de minhas professoras Dayce e Filó por tudo que me ensinaram quando eu nem sabia que poderia aprender; Ivany e Marília por me darem a certeza de que não havia nada de errado em ser curioso; Taba e Vanzella por me ensinarem a manter a cabeça sempre erguida; Pedro e Ana por me mostrarem o tamanho de nossas responsabilidades e a importância de nossas ideias.

Não poderia deixar de lembrar também dos professores da FAUUSP que, ao dedicar-me à Arquitetura, finalmente, me fizeram sentir-se em casa. Clice, Érica, Álvaro, Alexandre, Sílvio, Marcos, Eugenio e Milton vocês fizeram toda diferença durante minha graduação; Eugenio obrigado por continuar ao meu lado agora na pós, sem sua serenidade, perspicácia e sabedoria certamente teriam sido dois anos muito mais difíceis. Como você me ensinou, buscamos neste tempo nos ocupar e não nos preocupar.
Agradeço também àqueles arquitetos e arquitetas que participaram da organização e da concorrência do Concurso. A dedicação de vocês, as noites em claro, os sacrifícios e as abdicações pelos quais vocês passaram geraram não só um pedacinho da minha São Paulo, mas também uma história que me orgulho de contar. Neste ponto não poderia deixar de mencionar a colaboração de Michel Gorski, Jamil Kfouri, Paulo Kawahara, Joel Ramalho Junior, Péricles Gomes, Nelson Xavier, Newton Massafumi, Siegbert Zanettini, Marcos Acayaba, Roberto Aflalo Filho, Roberto Mac Faden, José Victor Couto e Paulo Bruna, que com suas conversas e testemunhos, concedidos com tanta generosidade à esta pesquisa, contribuíram enormemente com a compreensão das entrelinhas deste processo.

Por fim, agradeço aos meus amigos e colegas que, com coragem e alegria, fazem esta travessia ao meu lado. 



\section{Resumo}

A partir da reunião e leitura crítica das propostas premiados pelo Concurso Público Nacional para Reurbanização do Vale do Anhangabaú, esta dissertação busca identificar e compreender algumas das estratégias projetuais que se encontravam em voga na cultura arquitetônica brasileira na virada dos anos de 1980. É por meio do corpo destes projetos, construídos ou não, que buscaremos cristalizar nas páginas seguintes uma ferramenta de trabalho útil para arquitetos e urbanistas envolvidos com o planejamento e a construção de espaços livres públicos.

Tendo como pano de fundo um importante momento de transformações políticas e sociais no Brasil, este trabalho busca analisar também, para além dos aspectos arquitetônicos, os motivos que levaram à opção pelo concurso como meio legítimo e inquestionável para o desenvolvimento deste trecho de São Paulo.

Palavras-chave: Concurso Anhangabaú, sistema de espaços livres, arquitetura da paisagem 



\section{Abstract}

As per meeting and detailed reading of awarded proposals from the Vale do Anhangabaú Redevelopment National Public Contest, this dissertation seeks to identify and understand some projects strategies that were being used by the Brazilian architectural culture by the end of 1980's .Is thru this projects, finalized or not, that we will try in the following pages crystalize a useful tool for architects and urban planner involved with planning and constructions of open public spaces..

Having as back ground an important Brazilian political and social transformation moment, this work also seeks, beyond the architectural aspects, the reasons that took the contest as a legitimate and unquestionable way for this Sao Paulo section development

Key-words: Concurso Anhangabaú, sistema de espaços livres, arquitetura da paisagem 



\section{Lista de Figuras}

fig.1 Vale do Anhagabaú, visto apartir do Viaduto do Chá, 1908 - arquivo Acervo O Estado de São Paulo 22

fig.2 Viaduto do Chá, 1912 - Guilh. Gaensly, IMS 23

fig.3 Vale do Anhnagabaú, vista área, década de 1930 - autor desconhecido 24

fig.4 Graf Zeppelin sobre São Paulo, 1933 - autor desconhecido 25

fig.5 Avenida Nove de Julho, década de 1930 - Dmitri Kessel, acervo revista Life 26

fig.6 Postal.Edificio Marinelli, Banco do Brasile Altino Arantes, 1955. Chico Albuquerque, IMS 27

fig.7 Carnaval no Anhangabaú, adeécada de 1960 - autor desconhecido 28

fig.8 Anhangabaú a noite, 1970 - Ivo Justino 29

fig.9 Reforma do Anhangabaú, 1988 - auor desconhecido 30

fig.10 Gravura satírica de Jules Marin, 1888 - Cortesia fau-USP 35

fig.11 Planta cadastral do vale do Anhangabaú, 1907 - Arquivo SIURB 36

fig.12 Projeto de Melhoramentos, 1907 - Arquivo SIURB 36

fig.13 Proposta de Stockler das neves, 1911, editada por Hereñu 200736

fig.14 Foto aérea, 1925

39

fig.15 Teatro Municipal e São José a partir do Palacete Prates, 191840

fig.16 Ville de l'Avennir, Eugene Henard, 1911

44

fig.17 Sampaio Moreira, 192644

fig.18 Ilustração Pano de Avenidas, $1930 \quad 45$

fig.19 Plano de Avenidas, $1930 \quad 45$

fig.20 Viaduto do chá, década de $1940 \quad 46$ 
fig.21 Plano de Avenidas revisto, 193846

fig.22 Cena do filme Metropolis, de Fritz Lang, 192749

fig.23 Aveinida São João década de 1930 - Dmitri Kessel, acervo revista Life 50

fig.24 Projeto Anhangabaú, EMURB, 198054

fig.25 Projeto Anhangabaú, EMURB 198055

fig.26 Panfleto de inauguração Elevado Costa e Silva, 197158

fig.27 Seminário promovido pelo IAB-SP, $1981 \quad 62$

fig.28 Reprodução Edital e Programa do Concurso, acervo IAB, 198164

fig.30 Reprodução Edital e Programa do Concurso, acervo IAB, 198165

fig.29 Reprodução Edital e Programa do Concurso, acervo IAB, 198165

fig.31 Reprodução Edital e Programa do Concurso, acervo IAB, 198166

fig.32 Reprodução Edital e Programa do Concurso, acervo IAB, 198166

fig.33 Reprodução Edital e Programa do Concurso, acervo IAB, 198167

fig.34 Reprodução Edital e Programa do Concurso, acervo IAB, 198167

fig.35 Panfleto de divulgação do Seminário aberto, Acervo IAB, 198170

fig.36 Programação do Seminário aberto, Acervo IAB, 198170

fig.37 Ata do Juri, acervo do IAB, 1981

fig.40 Rosa Kliass e Jorge Wilheim, $1^{\circ}$ colocados, ACSP 1741 p06 78

fig.38 Elgson Gomes, $2^{\circ}$ colocado - ACSP, n 1745 p12 78

fig.39 Siegbert Zanettini, Paulo Bastos e equipe, 3] colocados - ACSP 1751 p18 78

fig.41 Perspectiva do Vale do Anhnagabaú, acervo Aflalo / Gasperini Arquitetos 80

fig.42 Corte transversal pelo Vale do Anhnagabaú, acervo Aflalo / Gasperini Arquitetos 83

fig.43 Detalhe do corte transversal pelo Vale do Anhnagabaú, acervo Aflalo / Gasperini Arquitetos 83

fig.44 Redesenho da propota de Croce, Aflalo e Gasperini. Acervo do Autor 85

fig.45 Ao lado, foto inserção do projeto de CAG sobre perspectiva à mão de Siegbert Zanettini - Carlos Eduardo Miller e Bhakta Krpa 87

fig.46 A cima, foto inserção do projeto de CAG sobre perspectiva à mão de Siegbert Zanettini - Carlos Eduardo Miller e Bhakta Krpa 87

fig.47 Perspectiva do Vale do Anhnagabaú, prancha entregue ao concurso - acervo Julio 
fig.48 Corte tranversal, prancha entregue ao Concurso - acervo Julio Gadelha Barretto 91

fig.49 Seção pontes pré-fabricadas, prancha entregue ao Concurso - acervo Julio Gadelha Barretto 91

fig.50 Redesenho da propota de Carlos Bratke e Joaquim Barretto. Acervo do Autor 93

fig.51 Ao lado, foto inserção do projeto de BB sobre perspectiva à mão de Siegbert Zanettini - Carlos Eduardo Miller e Bhakta Krpa95

fig.52 A cima, foto inserção do projeto de BB sobre perspectiva à mão de Siegbert Zanettini - Carlos Eduardo Miller e Bhakta Krpa95

fig.53 Perspectiva do Vale do Anhnagabaú, prancha entregue ao concurso - acervo Marcos Acayaba 96

fig.54 Croqui do sistema de viário principal, prancha entregue ao concurso - acervo Marcos Acayaba 98

fig.55 Planta e corte esquemático da estação central, prancha entregue ao concurso acervo Marcos Acayaba 100

fig.56 Setorização, prancha entregue ao concurso - acervo Marcos Acayaba 101

fig.57 Redesenho da propota de MArcos Acayaba, Edgard Dente e Julio Katinsky Acervo do Autor 103

fig.58 Ao lado, foto inserção do projeto de ADK sobre perspectiva à mão de Siegbert Zanettini - Carlos Eduardo Miller e Bhakta Krpa 105

fig.59 A cima, foto inserção do projeto de ADK sobre perspectiva à mão de Siegbert Zanettini - Carlos Eduardo Miller e Bhakta Krpa 105

fig.60 Perspectiva do Vale do Anhnagabaú, prancha entregue ao concurso - acervo escritório APBA 108

fig.61 Diagrama de eixos, prancha entregue ao concurso - acervo escritório APBA 111

fig.62 Diagrama de conceitual de intenções, prancha entregue ao concurso - acervo escritório APBA 113

fig.63 Levantamento fotográfico, usuário no chafariz, prancha entregue ao concurso acervo escritório APBA $\quad 115$

fig.64 Levantamento fotográfico, vendedor ambulante, prancha entregue ao concurso acervo escritório APBA $\quad 115$

fig.65 Levantamento fotográfico, travessia de pedestres, prancha entregue ao concurso acervo escritório APBA $\quad 115$

fig.66 Levantamento fotográfico, escadaria pública, prancha entregue ao concurso - 
fig.67 Levantamento fotográfico, monumento público, prancha entregue ao concurso acervo escritório APBA 115

fig.68 Redesenho da propota de Siegbert Zanettini e Paulo BAstos - Acervo do Autor 117

fig.69 Ao lado, foto inserção do projeto de BZ sobre perspectiva à mão de Siegbert Zanettini - Carlos Eduardo Miller e Bhakta Krpa 119

fig.70 A cima, foto inserção do projeto de BZ sobre perspectiva à mão de Siegbert Zanettini - Carlos Eduardo Miller e Bhakta Krpa 119

fig.71 Foto da Maquete do Vale do Anhnagabaú, ACSP 1745 p12 120

fig.72 Faseamento da obra, ACSP 1745 p12 122

fig.73 Redesenho da propota de Elgson Gomes - Acervo do Autor 125

fig.74 Ao lado, foto inserção do projeto de EG sobre perspectiva à mão de Siegbert Zanettini - Carlos Eduardo Miller e Bhakta Krpa127

fig.75 A cima, foto inserção do projeto de EG sobre perspectiva à mão de Siegbert Zanettini - Carlos Eduardo Miller e Bhakta Krpa127

fig.76 Perspectiva do Vale do Anhnagabaú, prancha entregue ao concurso - retirado do site http://www.jorgewilheim.com.br/legado/Projeto/visualizar/1835 em 04/07/2016 128

fig.77 Diagramas analíticos e faseamento da obra, revista Projeto n 31 p 35130

fig.78 Perspectiva do Vale do Anhnagabaú e planta de priorização, prancha entregue ao concurso - retirado do site http://www.jorgewilheim.com.br/legado/Projeto/visualizar/1835 em 04/07/2016 133

fig.79 Redesenho da propota de Jorge Wilheim, Rosa Kliass e Jamil Kfouri - Acervo do Autor 135

fig.80 Ao lado, foto inserção do projeto de WKK sobre perspectiva à mão de Siegbert Zanettini - Carlos Eduardo Miller e Bhakta Krpa 137

fig.81 A cima, foto inserção do projeto de WKK sobre perspectiva à mão de Siegbert Zanettini - Carlos Eduardo Miller e Bhakta Krpa 137

fig.82 Planfeto informativo da inauguração das passarelas do Terminal Bandeira, 1988 145

fig.83 Obras de implantação passarelas do Terminal Bandeira, década de 1980 145

fig.84 No lugar do pontilhão, fonte e café rebaixado, 1992 - Eduardo Benzatti 147

fig.85 Teatro Municipal a partir do Vale, 1992 - Eduardo Benzatti 148 
fig.86 Tribuna e Viaduto do chá a partir do Vale, 1992 - Eduardo Benzatti 148

fig.87 Vista geral a partir da Praça Pedro Lessa, 1992 - Eduardo Benzatti 149 fig.88 Planta do Vale do Anhangabaú, versão revisada e implantada, redesenho QUAPÁ-SEL 152

fig.89 Vista da tribuna, autor desconhecido 155

fig.90 Base topográfica fornecida pelo Concurso, acervo Aflalo / Gasperini 158

fig.91 Perspectiva do projeto desenvolvido por Vilanova Artigas, 1974 acervo FAU-USP 162

fig.92 Página ao lado sobreposição dos seis projetos analisados, acervo do autor 165

fig.93 Proposta de Croce, Aflalo e Gasperini para restruturação do encontro da avenida São João com Anhangabaú, $1970 \quad 170$

fig.94 Passarela sob o viaduto do chá, obra de Croce, Aflalo e Gasperini, por volta de 1970 - autor desconhecido 170

fig.95 Diagrama de Doorn, Team X, Manifesto de Doorn, $1954 \quad 173$

fig.96 Urban Re-Identification Grid, 1953 - Alisson e Peter Smithson 175

fig.97 Redesenho da propota de Jorge Wilheim, Rosa Kliass e Jamil Kfouri - Acervo do Autor 178

fig.98 Redesenho da propota de Siegbert Zanettini e Paulo BAstos - Acervo do Autor 179

fig.100 Perspectiva do Vale do Anhnagabaú, prancha entregue ao concurso - retirado do site http://www.jorgewilheim.com.br/legado/Projeto/visualizar/1835 em 04/07/2016 182

fig.101 Fan Fest realizada durante a Copa do Mundo de Futebol de 2010

fig.99 FIGURA 182

fig.102 Lovejay Fountain Park,Lawrence Halprin, 1966185

fig.103 Fonte Vale do Anhangabaú, Kliass e Kfouri, 1991185

fig.106 Cena do filme Star Wars IV - Uma Nova esperança $1977 \quad 188$

fig.107 Cena do filme Star Wars V - O Império Contra-ataca 1980188

fig.104 FIGURA 188

fig.105 FIGURA 188

fig.110 Cena do filme Blade Runner $1982 \quad 189$

fig.111 Cena do filme Blade Runner 1982189 
fig.108 FIGURA 189

fig.109 FIGURA 189

fig.112 Perspectiva comparativa antes-depois do Vale do Anhnagabaú, prancha entregue ao concurso - acervo Julio Gadelha Barreto 195

fig.113 Corte longitudinal do Vale do Anhnagabaú com destaque para os edifícios propostos, prancha entregue ao concurso - acervo Julio Gadelha Barreto 195

fig.114 Perspectiva do Pavilhão botânico e da Rosa dos Ventos, prancha entregue ao concurso - acervo Julio Gadelha Barreto 197

fig.115 Comício das Direstas Já, mais de 1,5 milhões de pessoas se reuniram no Vale Acervo o Estado de São Paulo 199

fig.116 Página oposta, perspectiva apresentada ao concurso com destaque ao edifício proposto, acervo Marcos Acayaba 203

fig.117 Página oposta, corte transversal apresentada ao concurso com destaque aos edifícios propostos, acervo Marcos Acayaba 203 



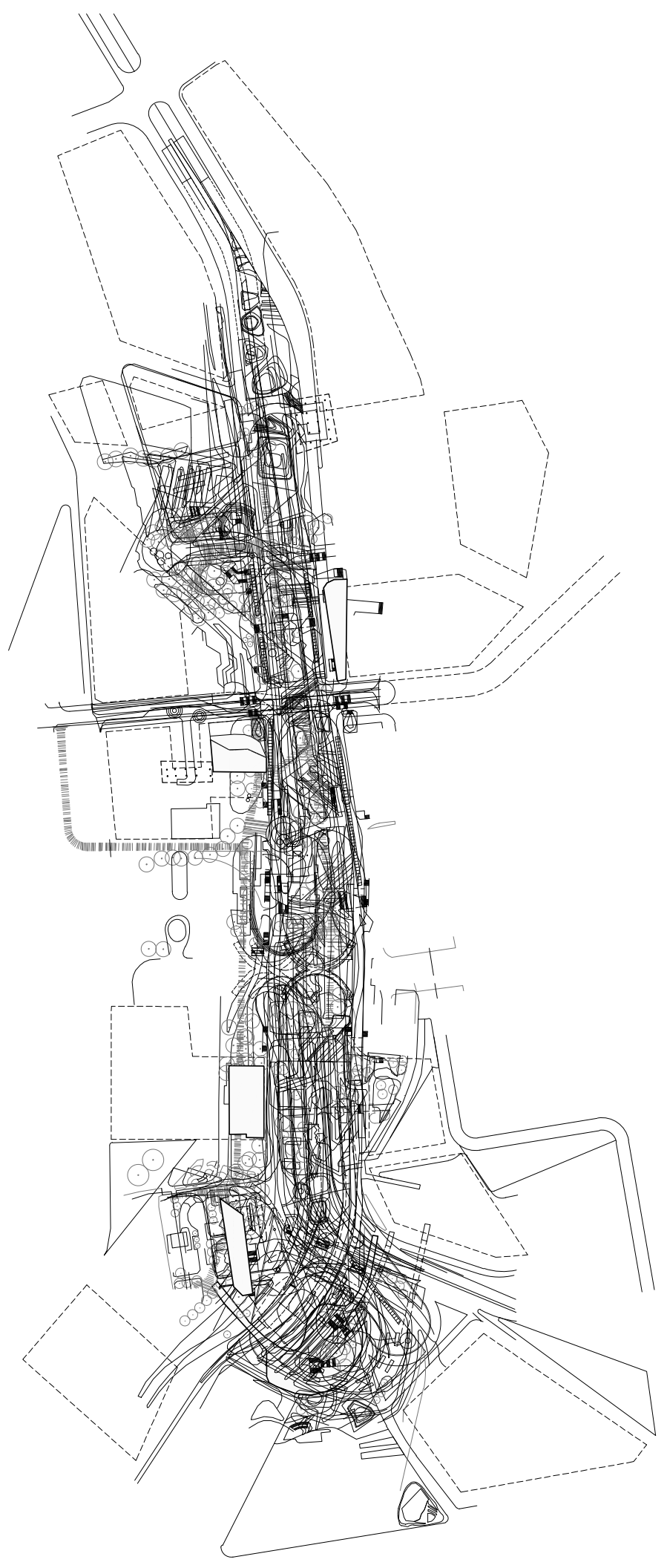




\section{Sumário}

Capítuulo I: A Metamorfose de uma Paisagem

Das bordas ao centro: a sugestão de uma (nova) paisagem 43

Das formigas ao jardim de Bouvard 47

Do jardim à sala de visitas 51

Da paisagem estática à passagem dinâmica 57

Da passagem à concorrência 61

Da concorrência ao concurso

Capítulo II: O Concurso

Da organização do Concurso 69

As Propostas 87

A Implantação 149

Capítulo III: O Desenho e o Desejo

A opção pelo Concurso 169

Considerações sobre as Propostas 175

Considerações finais 215

Referências 220 


\section{Introdução}

Este volume sintetiza, sob a forma de uma dissertação, o conteúdo de seis ${ }^{1}$ das propostas premiadas pelo Concurso Público Nacional para Elaboração de Plano de Reurbanização do Vale do Anhangabaú, realizado entre fevereiro e junho de 1981 pela Prefeitura Municipal de São Paulo e IAB-SP. Tal como exporemos nas páginas seguintes, não se trata aqui de uma compilação destes projetos, mas, para além disso, uma leitura sobre a obra de homens e mulheres que, por meio de suas participações como concorrentes, organizadores ou incentivadores do Concurso, ajudaram a escrever um dos mais importantes capítulos da história recente da Arquitetura, Urbanismo e do Paisagismo de São Paulo e do Brasil.

A reunião deste material permite a aproximação de um momento metamórfico, onde não só o espaço urbano como também o quadro social, cultural e político se encontravam em transformação. Se a cidade da virada de 80 , aqui materializada pelo centro de São Paulo, já não atendia às necessidades e aos desejos de sua população, podemos perceber o mesmo nos de- bates sobre o espaço público, que assumia cada vez mais contornos participativos; no pluralismo de abordagens arquitetônicas e no processo de redemocratização, lenta, gradual, segura...e constante.

Do ponto de vista prático, esta dissertação está dividida em três capítulos. No primeiro, a luz da teoria de dupla artialização e de gênio do lugar de Alain Roger, buscaremos demonstrar de forma sintética o percurso pelo qual o Vale do Anhangabaú passou ao longo do século XX, de seu surgimento como paisagem à sua constituição como zona de concorrência no centro da cidade.

No segundo capítulo, a partir do levantamento das propostas premiadas e das atas produzidas pelos organizadores do Concurso, apresentaremos de forma sintética o processo de construção do Concurso e os seis projetos que serão analisados posteriormente. Aqui, em anexo a este testemunho, apresentaremos o resumo das entrevistas, ou melhor, das conversas, realizadas com os autores das seis propostas e com os orga- 
nizadores do Concurso.

Por fim, no terceiro e último capítulo, serão apresentadas algumas considerações acerca do Concurso e de seu resultado. Para tanto, dividiremos este capítulo em duas partes, sendo a primeira dedica à opção pelo concurso e a segunda à análise comparativa das propostas. Através desta análise, a despeito da classificação obtida em 1981, não pretendemos aqui encontrar um campeão, de fazer reparações históricas ou pintar futuros paralelos. Como revelou-se ao longo do desta pesquisa, nosso objetivo é estabelecer uma reflexão arquitetônica, uma conversa imaginária à beira da prancheta, uma ponderação sobre os riscos (grafados e assumidos), onde este autor, com grande honra, coloca-se como apenas mais um dos convidados. seis propostas. 


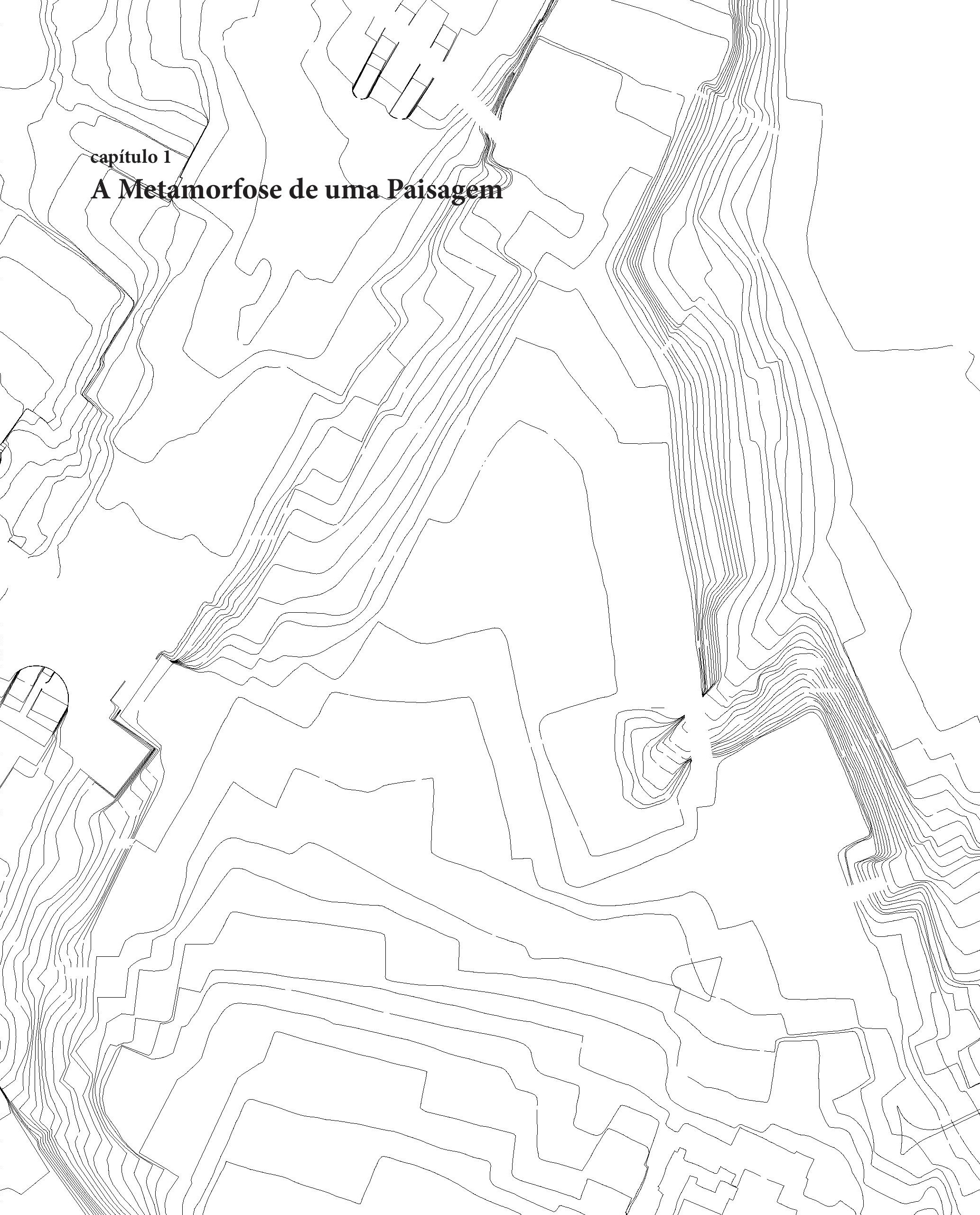




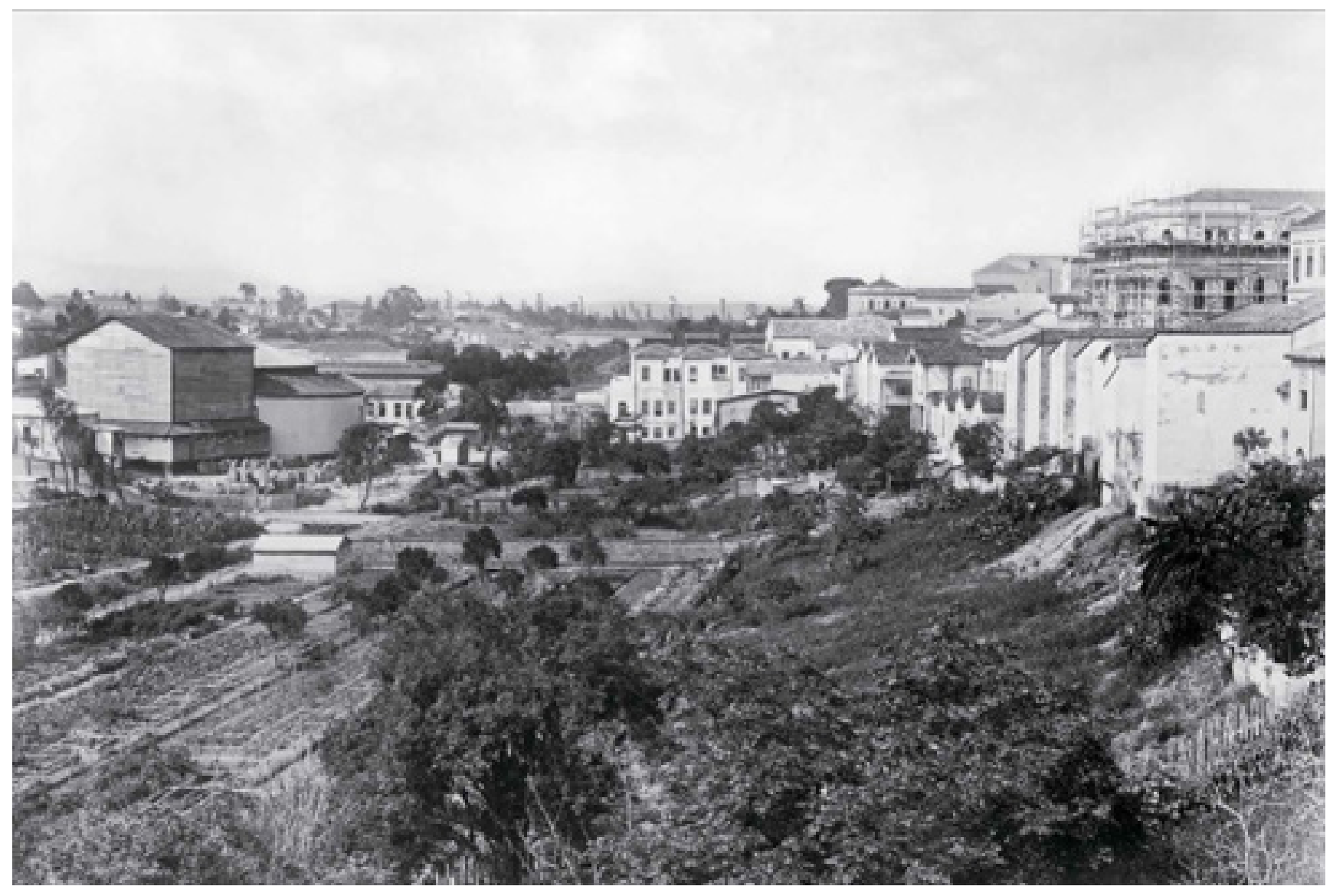

Reurbanização do Vale do Anhangabaú: propostas para recriação de uma paisagem 


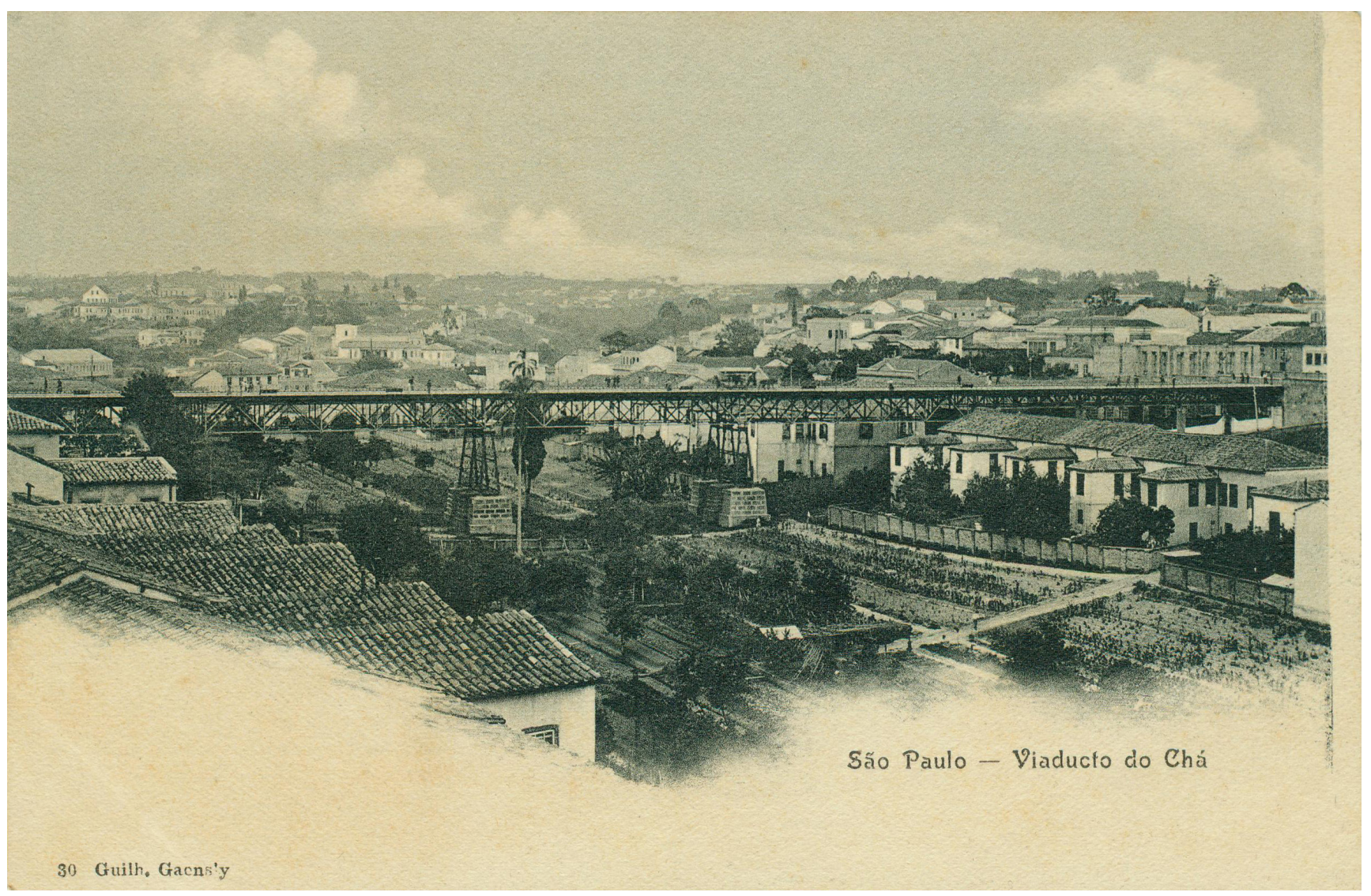

fig.2 Viaduto do

Chá, 1912 - Guilh. Gaensly, IMS 


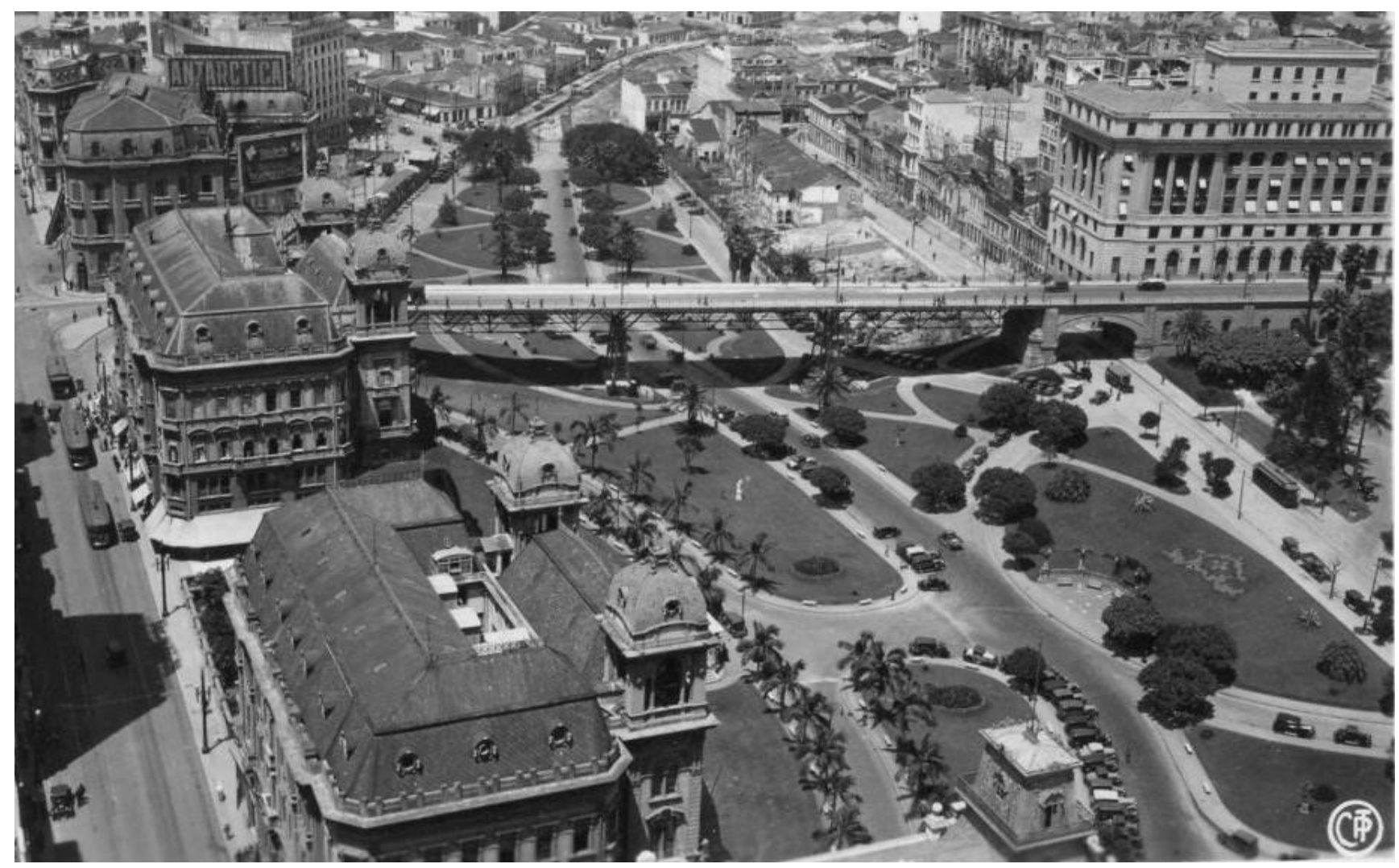

fig.3 Vale do Anh-

nagabaú, vista área, década de 1930 autor desconhecido 


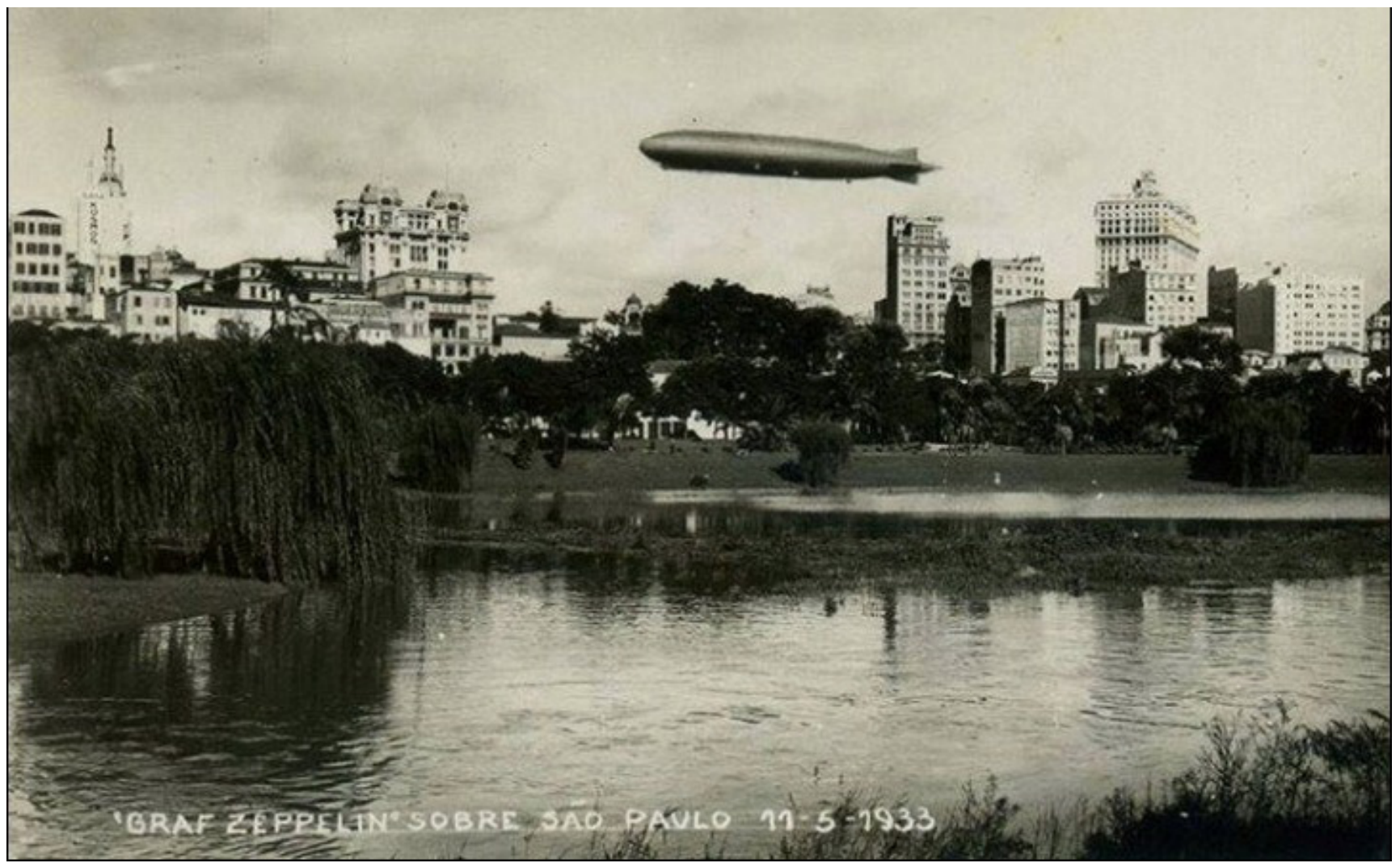

fig.4 Graf Zeppelin

sobre São Paulo,

1933 - autor desco-

nhecido 
fig.5 Avenida Nove de

Julho, década de 1930

- Dmitri Kessel, acervo revista Life

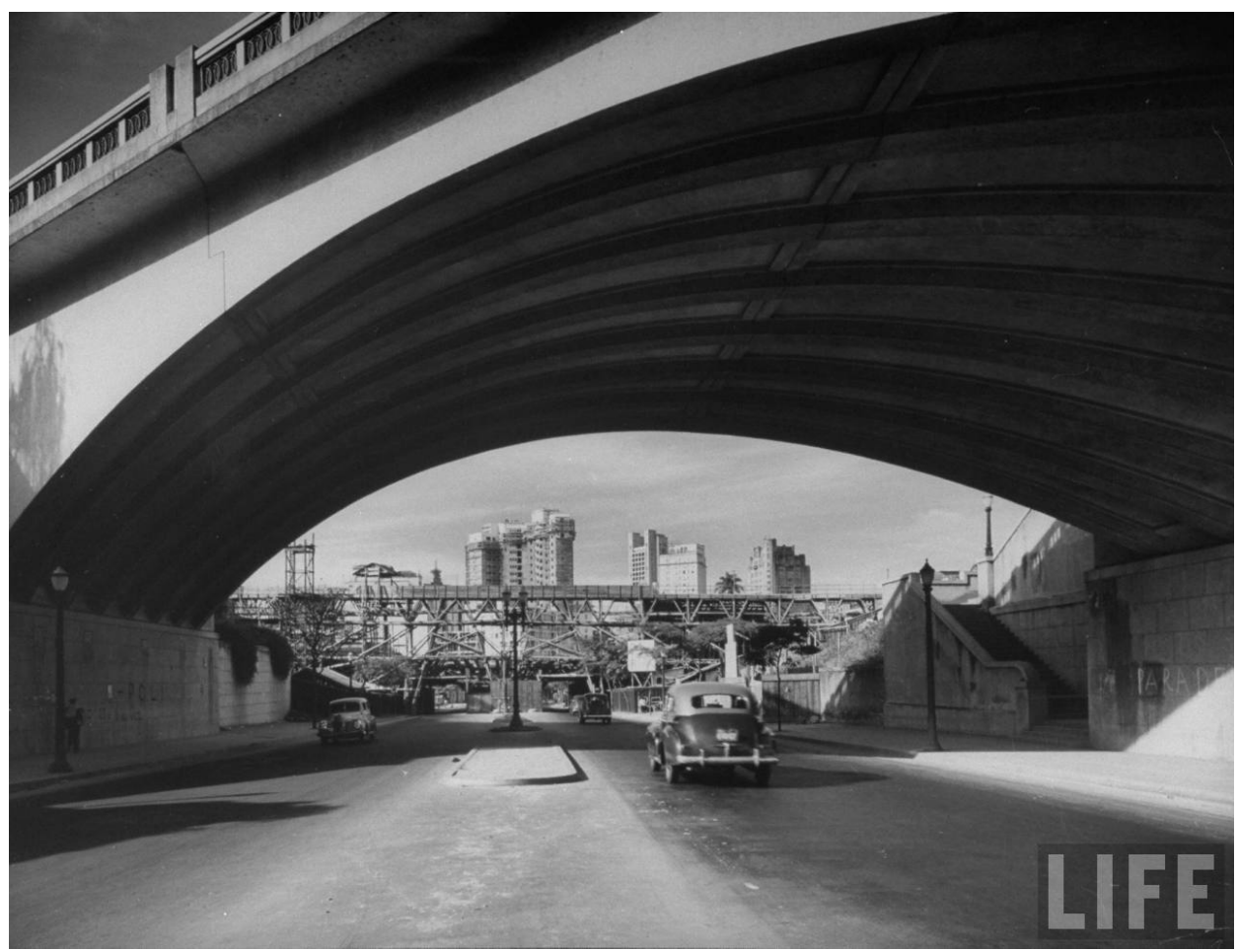

Reurbanização do Vale do Anhangabaú: propostas para recriação de uma paisagem 


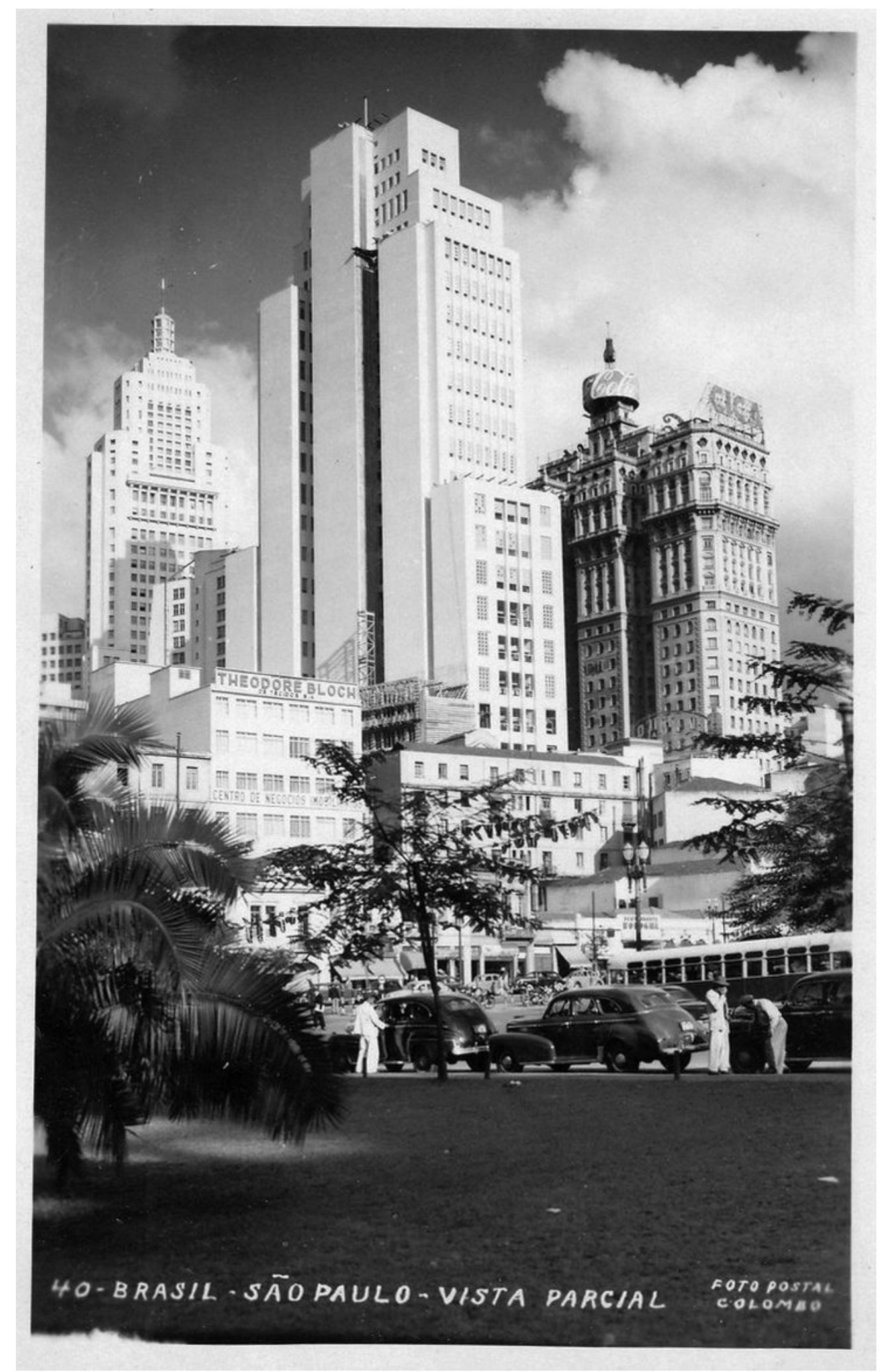

fig.6 Postal.

Edificio Marinelli,

Banco do Brasil

e Altino Arantes,

1955. Chico Albu-

querque, IMS 


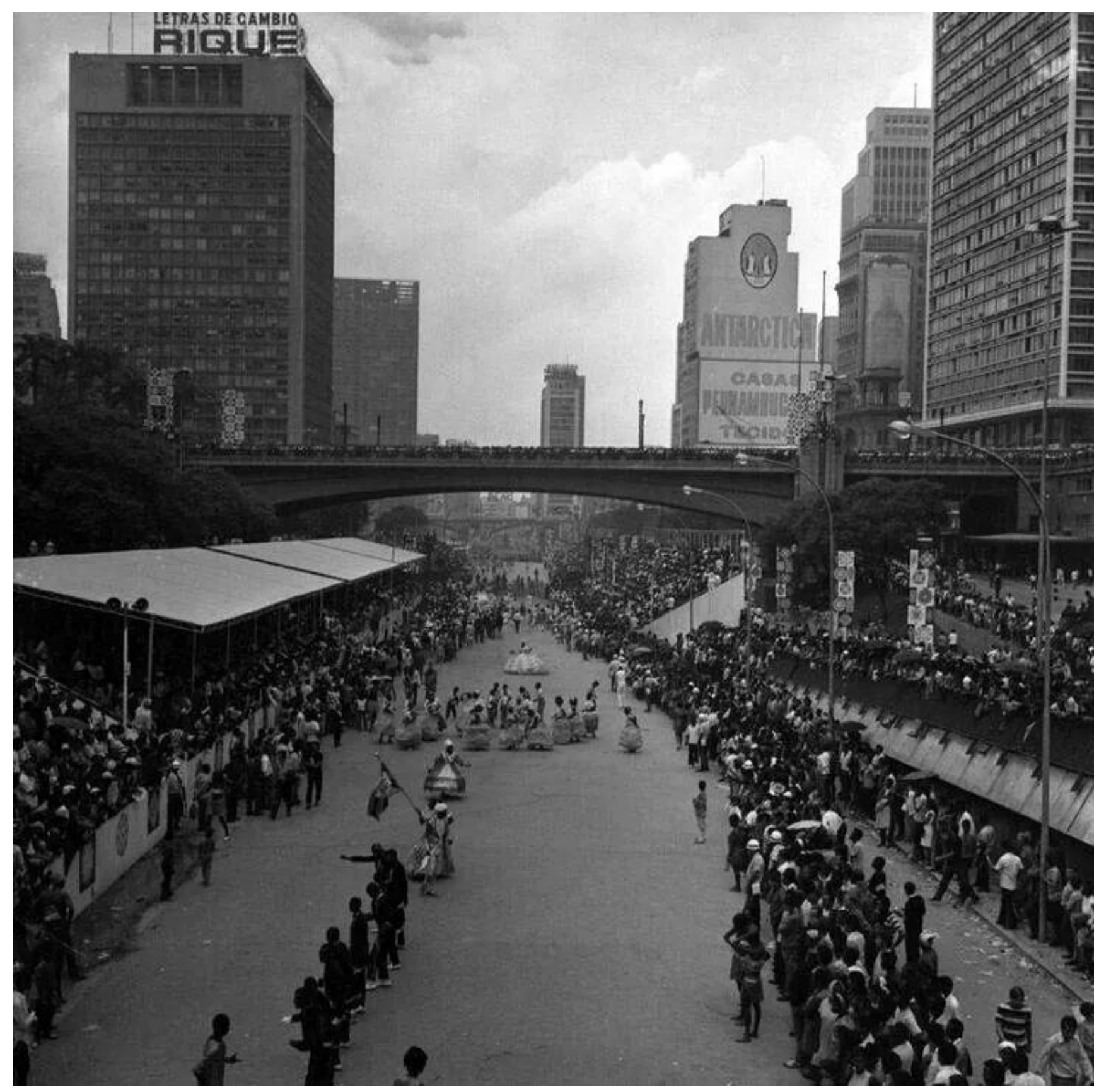

fig.7 Carnaval no

Anhangabaú, adeécada de 1960 - autor desconhecido 


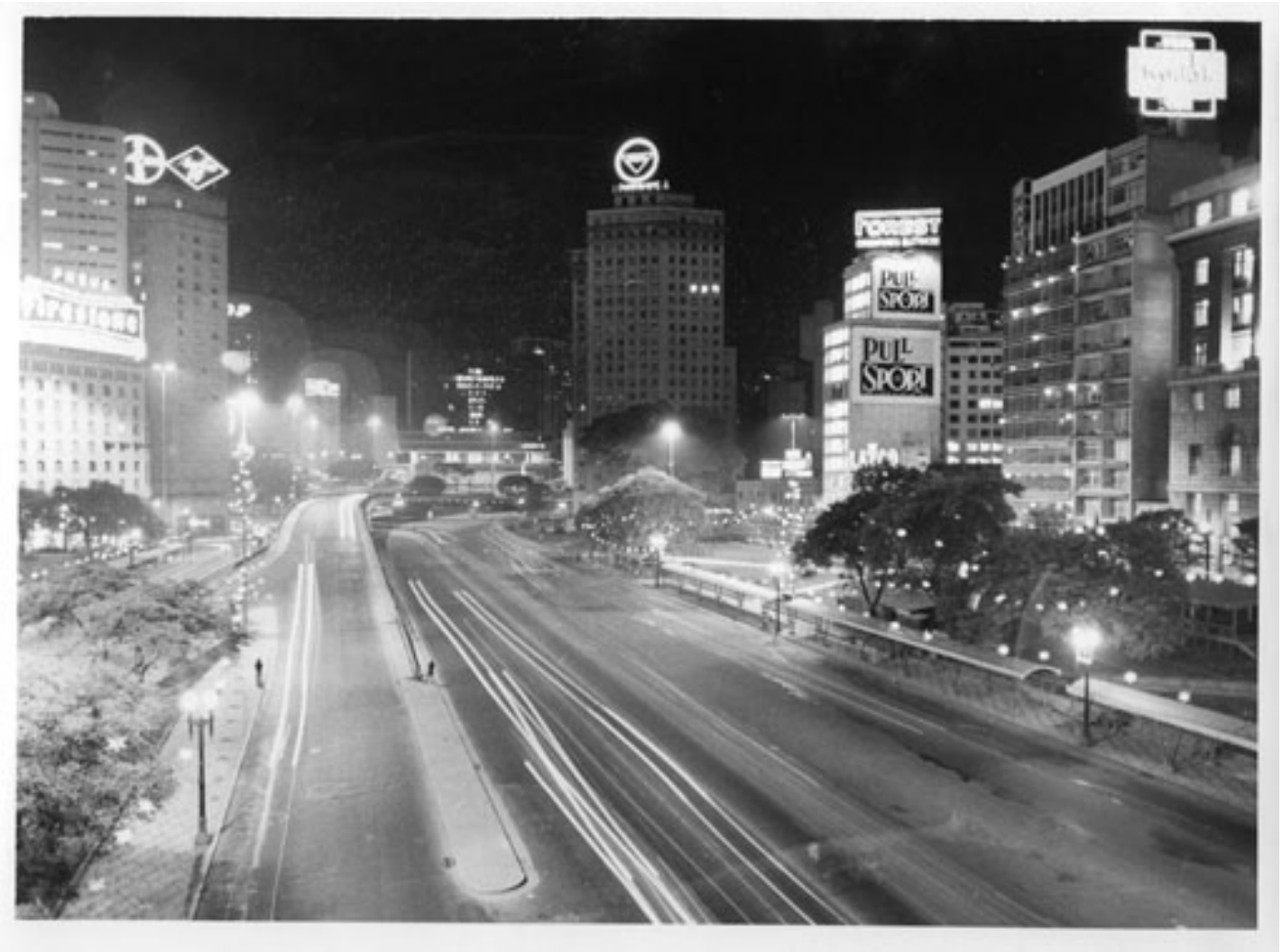




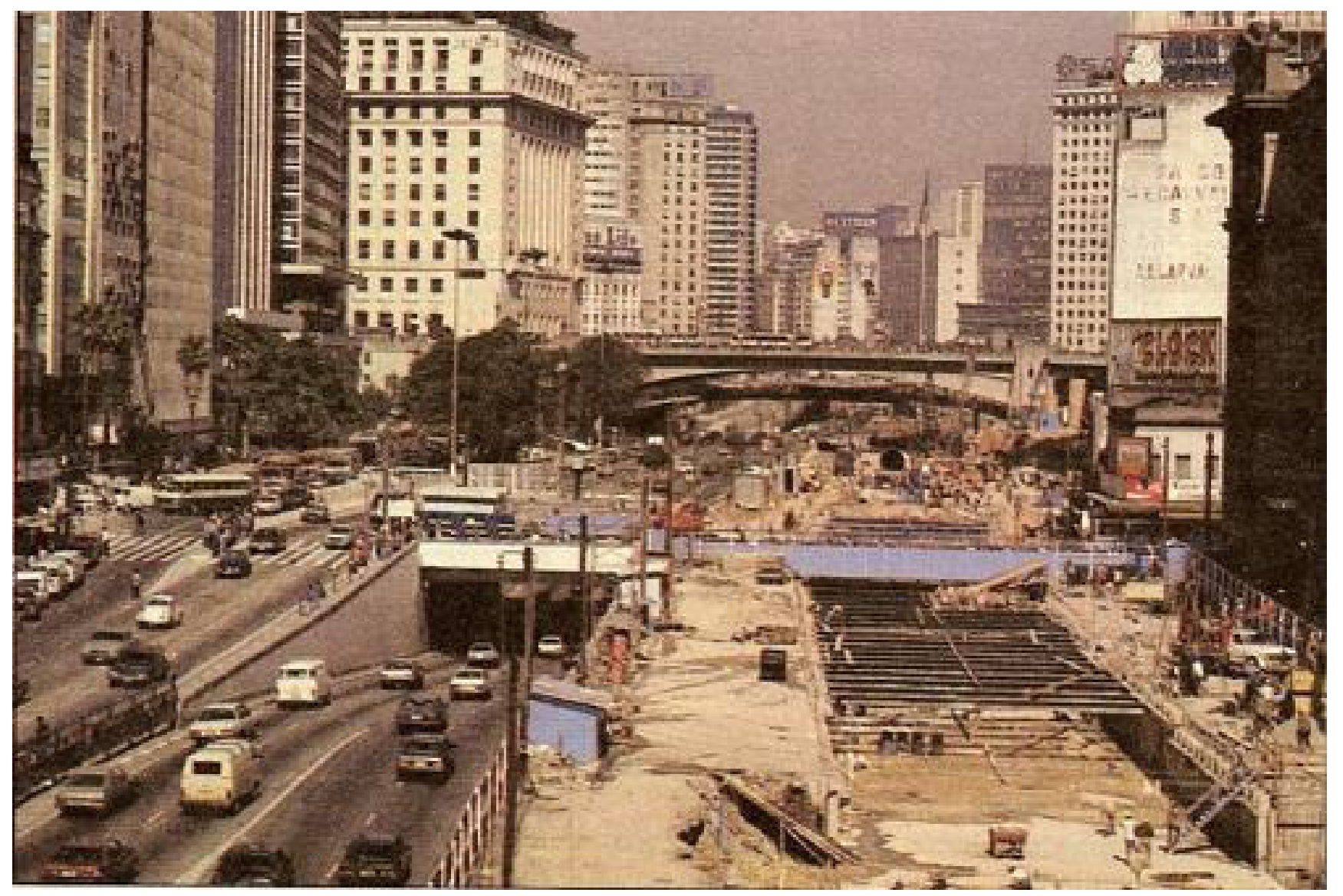

fig.9 Reforma do

Anhangabaú, 1988

auor desconhecido 


\section{AMetamorfose de uma Paisagem}

Tida como uma das principais paisagens da cidade de São Paulo, o Vale do Anhangabaú é também um dos um dos espaços públicos que mais se transformou, simbólica e espacialmente, na capital paulista ao longo do século XX. De um aglomerado de plantações de chá e agrião, pântano insalubre e território de "rãs coaxantes", o Vale se transformaria junto ao desenvolvimento cafeeiro $^{1}$ da virada de 1900 em um dos principais parques municipais, refletindo não só os padrões estéticos e sanitários da época como também o próprio desejo de se fazer representar de uma nova elite em formação.

Menos de vinte anos mais tarde, com a chegada de Prestes Maia à prefeitura e sob novos ideais de progresso, o Vale do Anhangabaú passaria por um novo processo de transformação. Ao desenho bucólico do parque de Bouvard seria sobreposto o traçado retilíneo do Plano de Avenidas, tornando o Anhangabaú, ou melhor, o agora sistema "Y", em um dos principais eixos viários da cidade, conectando suas porções norte e sul por vias de tráfego rápido.

Nos anos seguintes, apesar de se manter inalterado em sua forma espacial, o Vale do Anhangabaú passaria a ser um dos principais pontos para reuniões e manifestações populares da metrópole ${ }^{2}$, papel que se intensificaria a partir dos anos 1990 após sua

1 - Simões Junior demonstra como a inauguração da Estação da Luz em 1967 e o surgimento da "entrada nobre", por onde adentravam à cidade os grandes proprietários rurais, empresários e visitantes, à noroeste do centro alteraria o papel desempenhado pelo Vale do Anhangabaú dentro do tecido urbano da cidade. Para maiores detalhes deste processo recomenda-se a leitura SIMÕES JUNIOR, José Geraldo. Anhangabaú: História e Urbanismo. São Paulo. FAUUSP, 1995.

2 -Entre 1968 e 1977 o Vale do Anhangabaú passaria a receber anualmente o Carnaval Paulistano. Em 1984, 1,5 milhão de pessoas ser reuniram no Vale para comício pelas "Diretas Já", tornando-se o maior evento registrado neste espaço. Em 1992 o Vale receberia 750 mil pessoas na manifestação pública dos "caras pintadas". Durante a última década de XX e a primeira década de XXI o Vale passou a receber eventos religiosos, abrigando mais de 100 mil fiéis a cada evento. Nos últimos anos, além de abrigar festas esportivas e culturais 
requalificação ${ }^{3}$.

Não obstante a importância dos fatores econômicos, políticos e sociais dentro deste processo, visando uma abordagem capaz de lidar com a construção da Paisagem Urbana de forma sensível, é preciso considerarmos também como os aspectos culturais de cada época contribuíram para tal metamorfose. É neste sentido que, tomando os conceitos de dupla artilização ${ }^{4}$ e de gênio do lugar emprestadas de Alain Roger, poderíamos afirmar que as sucessivas ressignificações e reformas da paisagem do Vale se devem as (re)interpretações culturais depositadas sobre ele, ou seja, aos modelos artísticos, literários, cinematográficos e publicitários que pouco a pouco ganharam e perderam campo dentro do nosso olhar sobre o Anhangabaú. Como argumenta Roger (1995) utilizando-se das palavras de Oscar Wilde:

"a quem, portanto, senão aos impressionistas, devemos esses admiráveis nevoeiros acastanhados que deslizam nas nossas ruas, que esfumam os candeeiros e transformam nossas casas em sombras monstruosas? [...] Hoje em dia, as pessoas veem os nevoeiros, não porque haja nevoeiros, mas porque os pintores e os poetas lhes ensinaram o misterioso encanto de tais efeitos. "

Posto isto, buscaremos a seguir expor um pouco do pano de fundo cultural que vigorava em cada uma das metamorfoses sofridas pelo Vale e como isto influenciou em suas sucessivas atmosferas ${ }^{5}$.

\footnotetext{
de grande (fan-fest, virada esportiva e virada cultural) e pequeno porte (shows, apresentações de dança, performances e comemorações de feriados) o Vale voltou a ser palco de manifestações políticas, como as ocorridas em abril de 2016 em "Defesa da Democracia" que reuniram cerca de 50 mil manifestantes. 3 - A requalificação urbana do Vale do Anhangabaú iniciou-se em 1981 com a realização do Concurso Público Nacional para Elaboração de Plano de Urbanização do Vale do Anhangabaú. As obras só seriam iniciadas em 1984 e concluídas em 1991.

4 - Para Roger existe uma distinção clara entre duas formas de artilizar a natureza. A primeira é direta e realiza-se in situ, ou seja, tal qual uma tatuagem opera diretamente sobre o objeto. A segunda, em contrapartida, é indireta, in visu, e realiza-se através da mediação do olhar. Enquanto a primeira é importante para converter em arte um objeto neutro (no caso a natureza), a segunda faz-se necessária por impregnar o olhar e torná-lo capaz de, a partir do reconhecimento de modelos, embelezar à distância.

5 - Adotamos aqui a palavra atmosfera como a tradução para designação de George Simmel para Stimmung. Conforme alerta Adriana Veríssimo Serrão (2011), tem sido amplamente reconhecido a dificuldade de línguas latinas na tradução deste termo alemão, dado seu caráter polissêmico, mesmo na linguagem corrente. Para mais, no conceito simmeliano, convergem três aspectos: a conformação singular das partes que dota cada paisagem de um "caráter" individual; a conjunção dos traços anímicos do sujeito numa peculiar "disposição" ou "índole"; e, por fim, a fusão de ambas - a vertente objetiva e subjetiva - numa "tonalidade" ou "atmosfera" única.
} 


\section{Das bordas ao centro: a sugestão de uma (nova) paisagem}

Quando em 1877 o litógrafo francês Jules Martin e o engenheiro Fernando Albuquerque conceberam o Mappa da capital da província de São Paulo e nele deram especial destaque ao Jardim Público da Luz e à recém-inaugurada Ilha dos Amores na várzea do Carmo não o fizeram por acaso. Desde o início seus autores tinham como público alvo os paulistas do interior que vinham à capital para cuidar de negócios, uma classe social abastada e educada segundo os costumes europeus, que cultivava entre outros hábitos o passeio ao ar-livre e a contemplação da paisagem circundante e que poderiam encontrar nesses únicos dois locais a oportunidade de espairecer de modo civilizado 6 .

Portanto, não é de se estranhar que estes dois locais de contemplação e fruição paisagística se encontrassem nos limites da cidade, ou ao menos nos limites elegidos por Martin e Albuquerque ${ }^{7}$, uma vez que era lá, nas bordas do tecido urbano, que era possível reencontrar-se com o horizonte e a materialidade do mundo, fato reforçado pela construção do mirante do Jardim da Luz no início dos anos de 1870.

Mas se nos limites de São Paulo encontrávamos estes dois espaços alinhados com a estética pictórica internacional da época e altamente valorizados tanto do ponto de vista paisagístico como de investimentos ${ }^{8}$, no centro, em contraposição, o Vale do Anhangabaú, situado entre a colina histórica e o morro do Chá, era visto pelos pau-

6 - Eudes Campos in Arquitetura paulistana sob o Império: aspectos da formação da cultura burguesa em São Paulo, 1997

7 - Na Planta da Cidade de São Paulo de 1881 editada pela Companhia de Cantareira e Esgotos por exemplo, nota-se que os limites da cidade são muito mais extendidos que os apresentados por Martin e Albuquerque em seu mapa de 1877, revelando-se assim dois limites, duas auto-imagens: o assumido e o real. 8 - Presidente da Provincia de São Paulo nos anos de 1870, João Teodoro investiu boa parte dos recursos públicos durante seu mandato na modernização da Capital, que visava, como ele mesmo informou em um dos seus relatórios, "o conforto e a distração dos fazendeiros do interior". 
listanos do fim do século XIX como um entrave ao desenvolvimento da cidade' ${ }^{9}$ um fundo de quintal, um não-lugar destituído de imagem e significado. Nas palavras de Monteiro Lobato "o pântano, com valas de agrião e rãs coaxantes".

Não obstante, apesar deste desprezo pelo Anhangabaú, salta aos olhos o tratamento dado por Martin e Albuquerque ao Vale e seus arredores no mapa de 1877. Como destaca Simões Junior os autores retratam o vale como um segmento rural/urbano e com "dois pontos de espera", como que sugerindo um novo campo para o desenvolvimento da cidade. Coincidência ou não, três meses após a publicação deste mapa, Martin proporia a construção de um novo viaduto para o Vale do Anhangabaú, facilitando assim a travessia entre as duas colinas da região central. Para tanto, utilizando-se de sua $\operatorname{arte}^{10}$, Martin exporia na vitrine de sua loja situada à Rua São Bento uma perspectiva do Vale vizinho com destaque para o novo Viaduto.

Porém, se por um lado ao realizar tal perspectiva Martin apresentava uma nova obra de arquitetura e engenharia para São Paulo, por outro sugeria também, assim como os poetas dos haïkus japoneses, uma nova narrativa para o Vale: da posição periférica e desvanecida apresentada meses antes, vemos o Vale passar para o centro do quadro, ser seu ponto focal, reposicionando-se como novo centro relacional e imagem porvir de São Paulo; é ao encontrar esta fresta, ao alargar o tecido urbano, que ele arrasta para dentro da cidade a Paisagem e cristaliza em seus contemporâneos uma nova forma de se relacionar com o vale ${ }^{11}$. Nas palavras de Monteiro Lobato:

"Deram-lhe um dia o Viaduto do Chá, esse arrojo.... Os paulistanos pagavam sessenta réis para, ao atravessá-lo, conhecerem a vertigem dos abismos. E em casa narravam a aventura às esposas e mães, pálidas de espanto. Que arrojo de homem, o Jules Martin que construíra aquilo! ”

\footnotetext{
9 - Pablo Hereñu apresenta o Vale como uma verdadeira barreira durante este período, que seria vencida somente na última década do XIX com a construção do Viaduto do Chá.

10 - Jules Martin era formado em artes plásticas pela Escola de Belas Artes de Marselha, em 1944. Durante os anos 50 trabalhou no atelier do artista plástico Georg Schlater. Em 1869, já em São Paulo, realiza a exposição de algumas de suas pinturas nos salões de São Paulo.

11 - "É preciso alcançar os limites exteriores da cidade, reencontrar o horizonte e a materialidade do mundo para que a ideia manifesta de paisagem seja sentida. Por vezes, é verdade, a paisagem entra na cidade; quando a malha se alarga e o céu desce nela: a passagem do rio é disso exemplo fecundo" - Michel Corajoud, A paisagem é o lugar onde o céu e a terra se tocam, in Filosofia da Paisagem: uma antologia
} 


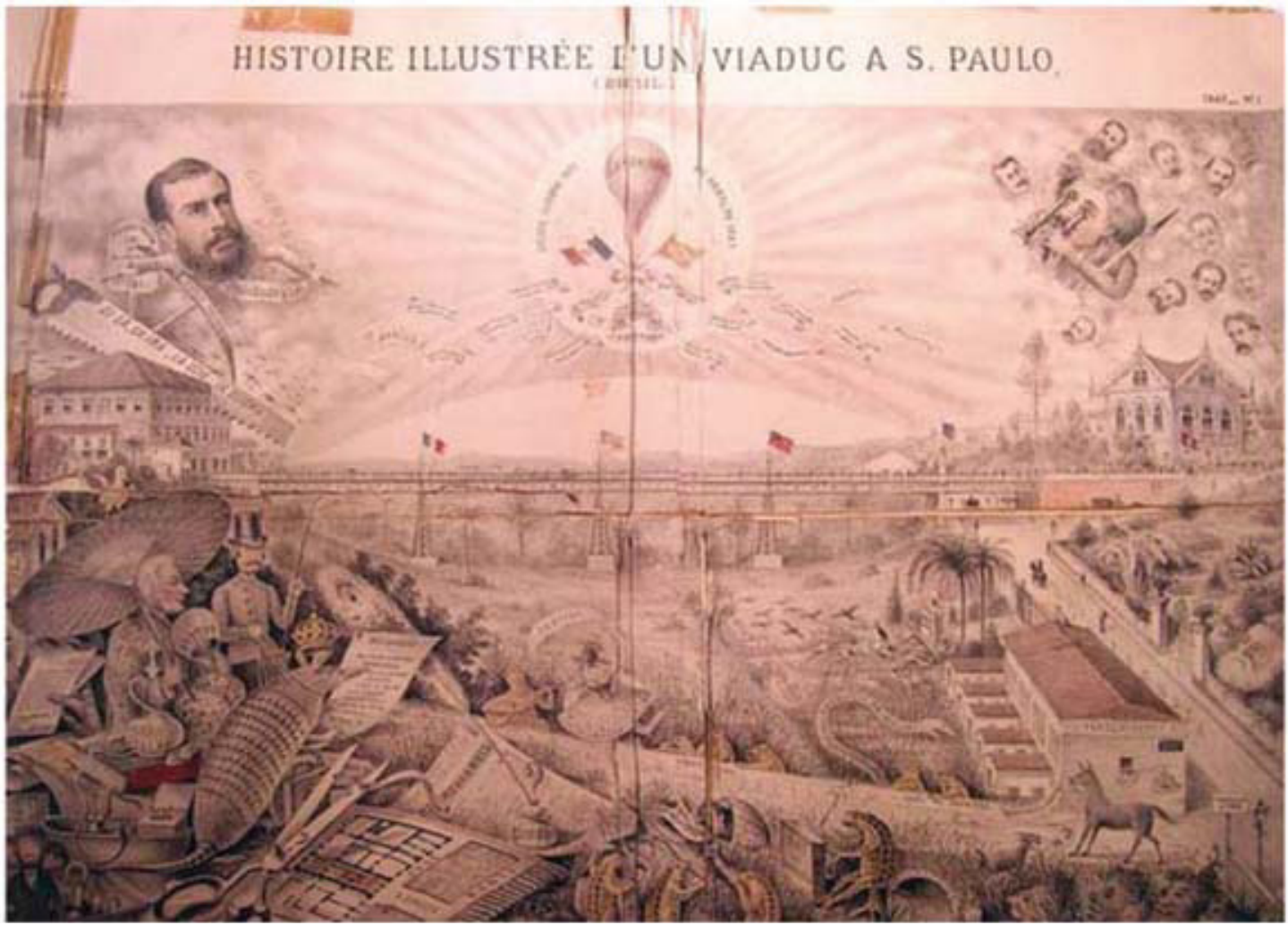

fig.10 Gravura satírica de Jules Marin, 1888 Cortesia fau-USP 
fig.11 Planta cadastral do vale do Anhangabaú, 1907 - Arquivo SIURB

fig.12 Projeto de Melhoramentos, 1907 - Arquivo SIURB

fig.13 Proposta de Stockler das neves, 1911, editada por Hereñu 2007
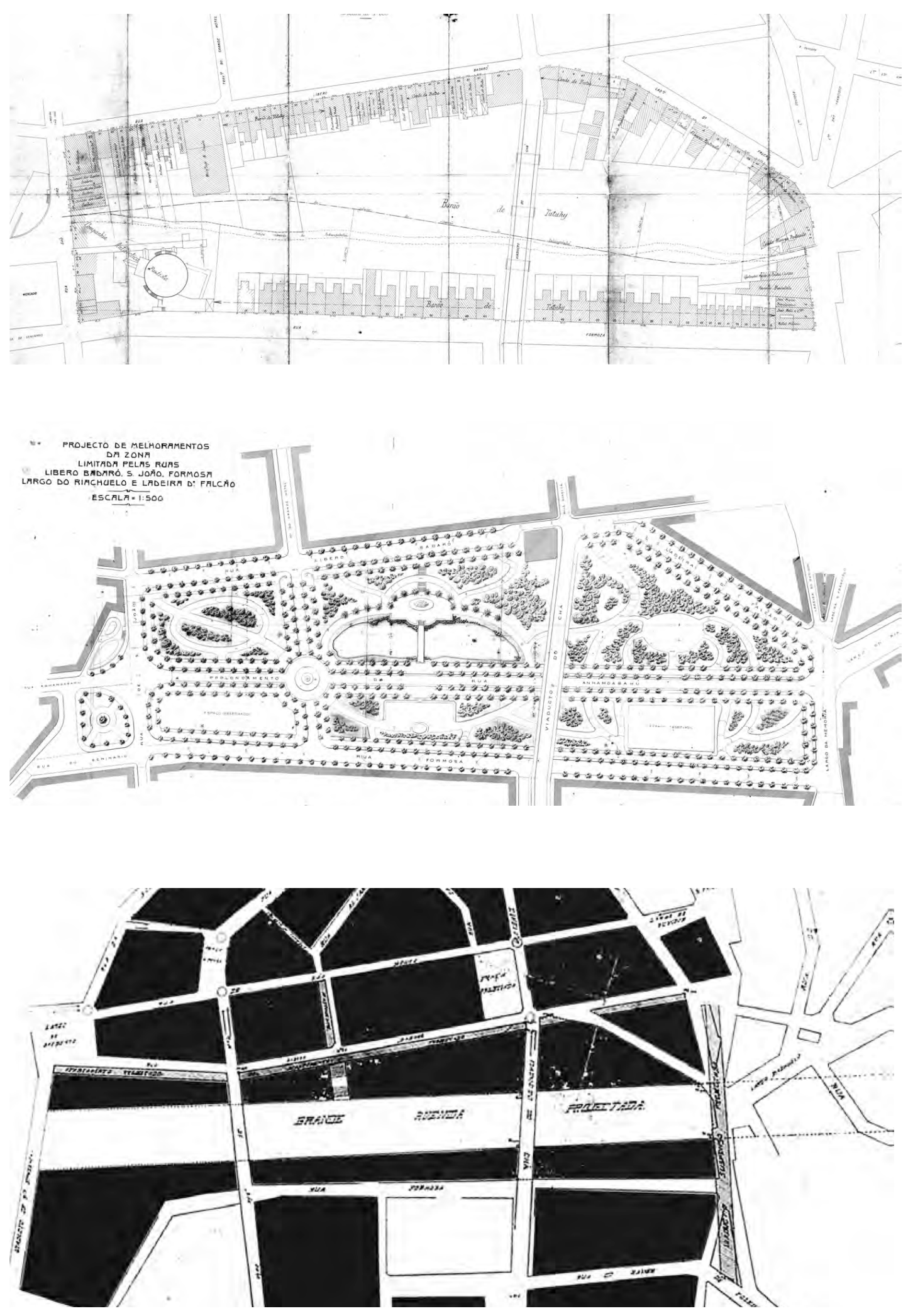

Reurbanização do Vale do Anhangabaú: propostas para recriação de uma paisagem 


\section{Das formigas ao jardim de Bouvard}

Porém, ainda em 1887, ao criar uma alegoria à construção do Viaduto do Chá ${ }^{12}$, Jules Martin parece não estar de todo certo de que ali existia de fato uma paisagem. Como podemos observar em sua litografia, em contraposição ao arrojo do viaduto que se fazia construir à época, Martin atribui ao vale uma conotação abertamente negativa, relacionando-o às bestas, aos animais do pântano, às formigas e ao passadismo da sociedade paulistana (vide representação do Barão de Tatuí na figura de um tatu coroado). É como se para o artista o Anhangabaú, no estado em que se encontrava, não encarnasse em si nada de belo ou elevado, fosse não mais do que uma porção de terras $^{13}$. Estaria ele, à semelhança do que fizera dez anos antes, sugerindo agora sua reforma?

Dificilmente poderemos saber a resposta para esta pergunta, mas fato é que passados menos de vinte anos o Anhangabaú tornar-se-ia objeto de diversas propostas de remodelação e valorização paisagística, perdurando este por sessenta anos até que em 1981 assumiria sua formar atual. Como aponta Campos Neto "até o último quartel do século XIX, os vales do Anhangabaú e do Tamanduateí nada mais eram que parte do quadro natural cercando o núcleo urbano, formado por campos, várzeas, matos, chá-

12 - Tal alegoria foi realizada em 1887 em decorrência da disputa entre J. Martin e o Barão de Tatuí em torno da demolição de sua casa para a construção do viaduto. Nas palavras de Campos Neto: "(...) a demolição do velho casarão, símbolo do passadismo e do imobilismo que os progressistas pretendiam superar, constituiu um divisor de águas em nossa história urbanística. Obstinadas, suas grossas paredes de taipa seriam substituídas por ágeis perfis metálicos lançados sobre o vale rumo ao futuro de São Paulo. O ato de demolir assumiria conotações positivas e desejáveis, marcantes para os futuros processos de transformação da cidade.." 13 - Para Alain Roger a dualidade terra / paisagem seria o homólogo à nudez / nu, onde terra e nudez representam objetos neutros e paisagem e nu são, por meio da inscrição de um código artístico, suas estetizações - Natureza e Cultura: a dupla artilização, in Filosofia da Paisagem: uma antologia 
caras e fundos de vale. Na medida em que o crescimento da cidade passou a cavaleiro do vale, a Oeste, e da várzea, a Leste, e a ocupação horizontal da colina atingiu seus limites, tais espaços [livres em áreas centrais] passaram a representar vazios passíveis de aproveitamento como áreas livres - uma vez que as condições físicas dessas zonas baixas e alagadiças desestimulavam a ocupação urbana propriamente dita”.

É neste ímpeto de ressignificação dos espaços livres centrais da cidade que entre os anos de 1907 e 1910 ao menos quatro propostas foram desenvolvidas e apresentadas para a remodelação do Vale do Anhangabaú. Sendo desenvolvidas pelo setor privado, caso da proposta apresentada por Alexandre Albuquerque; pelo poder municipal, caso das propostas de Augusto Carlos da Silva Telles em 1907 e Victor da Silva Freire e Eugênio Guilhem em 1911; ou pelo poder estadual, caso da proposta de Samuel das Neves em 1911, todas as propostas, cada uma a sua forma, buscavam transformações profundas e bastante detalhadas para o Vale.

Contudo, por serem propostas que defendiam visões urbanísticas fundamentalmente diferentes ${ }^{14}$, não houve consenso entre as partes à época, cabendo então ao poder municipal, conforme sugestão do Diretor de Obras Vitor da Silva Freire, contratar o renomado urbanista francês Josehp Antoine Bouvard ${ }^{15}$ para o desenvolvimento de um trabalho específico para São Paulo, o qual previa-se realizar em duas etapas: a primeira consistiria na realização de um relatório, resultado da apreciação dos projetos anteriormente apresentados e da visita à cidade a segunda, caso fosse necessário, a elaboração de um plano. Segundo Campos Neto, a opção por Bouvard "não pode ser considerada como uma arbitragem imparcial entre as alternativas em discussão para os 'melhoramentos de São Paulo'. Antes, a visita do arquiteto francês seria uma resposta à estratégia do fato consumado adotada pelos partidários do projeto Samuel das Neves. Escolhido por Victor Freire, Bouvard representava posições assumidas pelo Diretor de Obras; ao mesmo tempo, trazia na bagagem o aval da cultura francesa e o prestigio de Paris, sem o qual seria impensável contestar o modelo parisiense que fundamentava ideologicamente a proposta de Neves. A emulação de Buenos Aires, por sua vez, permitia que o exemplo carioca e sua 'avenida central'

14 - Pablo Hereñu in Sentidos do Anhangabaú, 2007 p. 101

15 - Joseph Antoine Bouvard (1840 - 1920), graduou-se Arquiteto na Escola Superior de Belas Artes de Paris em 1964. Foi colaborador de Jean-Charles Alphand, diretor de Obras d Paris, contribuindo com a realização da Exposição Universal de 1889. Em 1991 sucederia Alphand neste cargo, ocupando até 1911, ano que se torna diretor administrativo dos serviços de Arquitetura, Promenades, Plantio e Festas de Paris. 


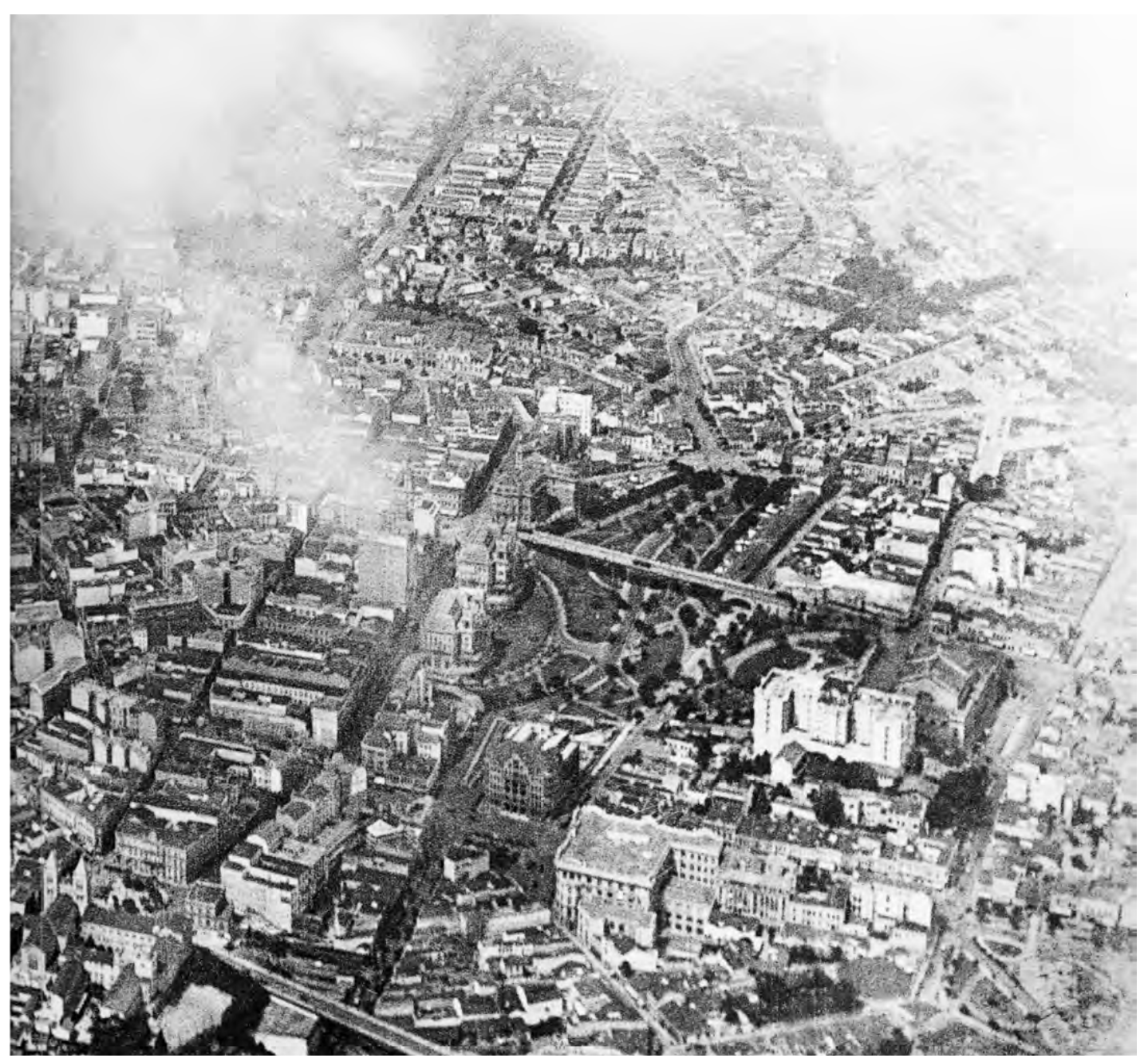

fig.14 Foto aérea, 1925

pudessem ser superados por uma experiência sul-americana com legitimidade ainda maior que a do Rio de janeiro em termos da 'civilização' representada pela modernização urbana à europeia. " (CAMPOS NETO, 1999)

De fato, se por um lado o plano de Bouvard trazia em seu seio algumas estratégias conciliadoras como áreas para o desenvolvimento imobiliário e um redesenho da malha viária, por outro não abria mão de manter o desenho de um parque no leito do Vale do Anhangabaú, estratégia herdada de Freire-Guilhem e consentida pela municipalidade.

Para a região do Anhangabaú Bouvard previa a ocupação parcial da encosta, com a colocação de dois blocos simétricos, construídos precisamente em frente ao Teatro 
Municipal. Estes blocos teriam sua "frente" voltada para o vale e criariam no nível da Líbero Badaró um terraço-mirante, extensão do passeio público que se debruçaria e desfrutaria do panorama do vale.

Como destacado por Hereñu, é bem certo que questões de ordem prática como a salubridade das várzeas, o desenvolvimento econômico e a fluidez viária foram questões fundamentais dentro deste processo, mas, todavia, subsistia sobretudo um forte componente estético implícito, uma vontade de se fazer representar e de cristalizar por meio desta obra o sonho da capital do café em todo seu esplendor.

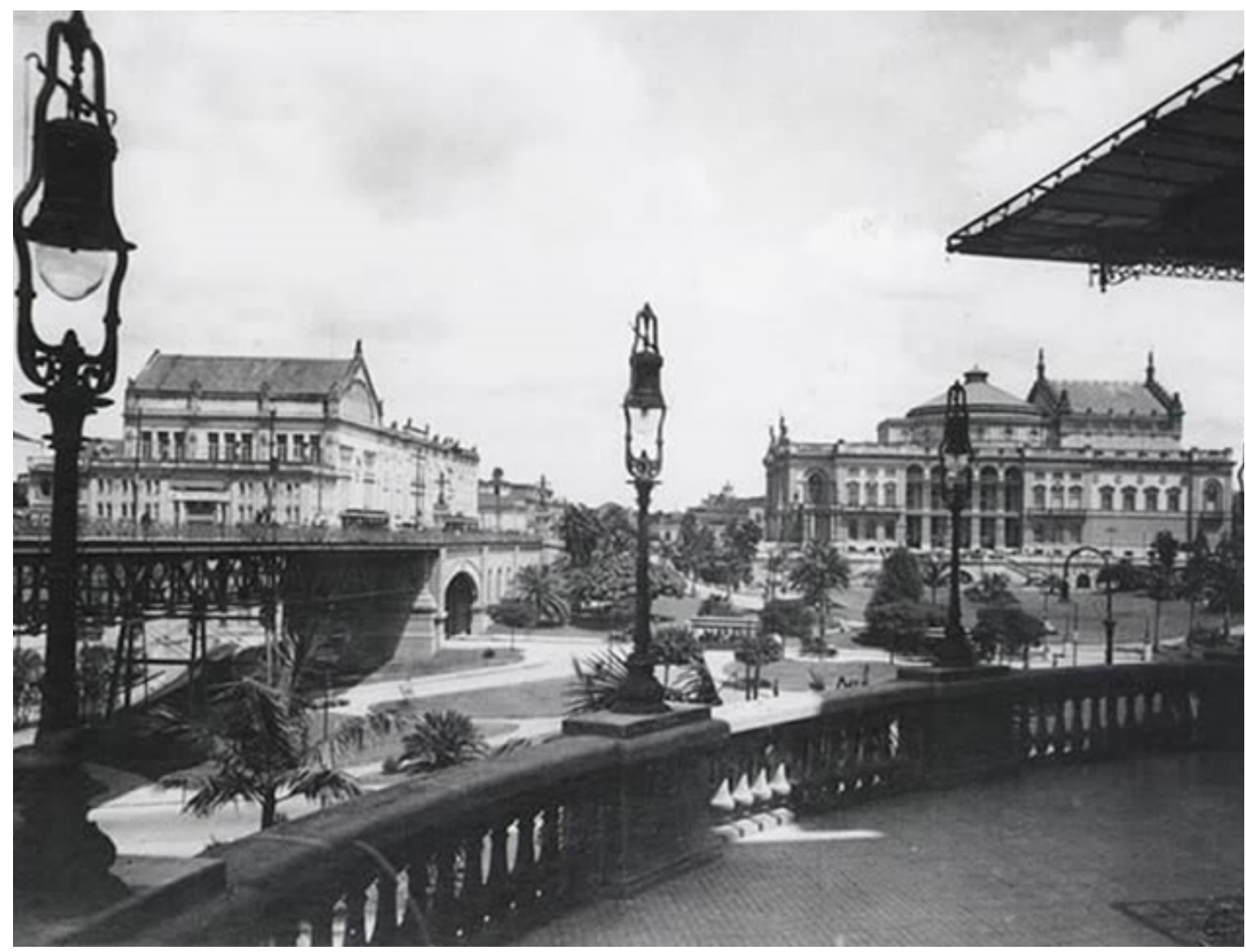




\section{Do jardim à sala de visitas}

No entanto, em menos de três décadas, a cidade de São Paulo parece sofrer uma inversão radical tanto em sua tradição urbanística quanto no próprio desenho de seus espaços urbanos. Como aponta Campos Neto "com a aposentadoria, em 1926, de Victor da Silva Freire (depois de permanecer por quase 27 anos no cargo municipal de Diretor de Obras), encerrava-se simbolicamente o ciclo de configuração da "capital do café", dando lugar a um novo grupo que teria como missão a estruturação da “metrópole da era industrial” (CAMPOS NETO, 1999).

Este novo grupo à que Campos Neto se refere é uma nova geração de engenheiros-arquitetos formada na Escola Politécnica de São Paulo e que tinha entre seus principais expoentes João Ulhôa Cintra (1887-1944) e Francisco Prestes Maia (1896-1965). Segundo Hereñu, esta geração tinha conhecimento dos trabalhos desenvolvidos pelo urbanista francês Eugène Henárd (1849 - 1923), autor da primeira Teoria Geral da Circulação e responsável por diversos planos de atualização e transformação para a cidade de Paris no início do século XX. Para Henárd, era preciso “investigar a influência que o progresso da ciência moderna e da indústria pode exercer sobre o planejamento e, particularmente, sobre o aspecto, das Cidades do Futuro" (HENÁRD, 1910), palavras que parecem sintetizar as propostas desenvolvidas pelos jovens engenheiros nos anos vindouros.

Sobre estas “influências”, Hereñu chama atenção para aquelas que agiram de forma mais contundente sobre o desenho e organização das cidades no início do século XX: o automóvel e o elevador. 
"O automóvel permitiu a expansão territorial horizontal e o desadensamento. O elevador, a multiplicação dos níveis da cidade e sua concentração. Sob esse ponto de vista, uma é a antítese da outra. Os modelos de cidade sugeridos por cada uma dessas máquinas são diametralmente opostos (...).

O potencial criativo oferecido para a cidade do futuro se confrontava com o potencial destrutivo sobre a cidade do presente herdada do passado. Esse conflito foi, e ainda é, um dos principais temas do urbanismo contemporâneo."

Mas para além de novas oportunidades de ordem criativa e construtiva, é preciso frisar que estas novas tecnologias também traziam consigo novas oportunidades de fruição e percepção do mundo; o sentir o mundo se transformara e consequentemente, como nos lembra o filósofo Charles Péguy com sua noção de Paisagem-evento ${ }^{16}$, a paisagem paulistana tornava-se outra.

E neste contexto que a figura do arranha-céu, da via rápida, das grandes visuais e da dimensão monumental passam a ganhar força dentro do gosto e da paisagem da paulistana. Já em 1924, como que anunciando as mudanças que estariam por vir, é inaugurado o primeiro arranha-céu de São Paulo, o edifício Sampaio Moreira, implantado exatamente entre os palacetes gêmeos do Conde Prates. Em oposição a estes dois "blocos" projetados com o objetivo de conformar uma unidade estável e que contavam com dois amplos belvederes no nível da cidade que se debruçavam sobre o Jardim do Anhangabaú, o Sampaio Moreira era um edifício que se pretendia singular e que oferecia aos seus usuários uma janela à paisagem a cinquenta metros de altura, longe do chão e de onde podia se vislumbrar de um só golpe toda a cidade de São Paulo. O Sampaio Moreira materializa, portanto, para além de um feito técnico, uma ruptura com o ideário de capital do café encarnado pelo plano jardim de Bouvard. São Paulo crescia e ensejava por ir mais alto e mais rápido, e com isso o Vale se transformaria novamente.

Alguns anos mais tarde, em maio de 1930, São Paulo conheceria então o "Plano de

16 - "A verdade da paisagem, caso exista, não se dá num "altar" ou numa vista congelada. A paisagem também não é acumulação(...). Ela é evento, ela é passagem (...) o movimento de articulação (cuja possibilidade precisa ser confirmada) entre a vida pessoal e a exterioridade que se adianta e se anuncia" - in Jean-Marc Besse, Ver a Terra, pag. 100 
Avenidas"17, de autoria de Prestes Maia e Ulhôa Cintra, e que poucos meses após sua apresentação seria condecorado com o prêmio máximo no IV Congresso Pan-americano de Arquitetura. O estudo continha um conjunto de propostas abrangente que abarcava diversos aspectos de estruturação da cidade e era permeado por uma monumentalidade constante.

Segundo Hereñu, o Anhangabaú desempenhava um papel chave dentro deste plano e sua importância se revelava em duas escalas distintas: " A primeira, mais abrangente, se dá no âmbito da estruturação viária norte-sul da cidade, através do "Sistema Y". A segunda, mais pontual, se revela na configuração de um recinto monumental que criaria a nova "sala de visitas" da cidade. " (HEREÑU, 2007)

Quanto à adjetivação (sala de visitas) e ao desenho dado por Prestes Maia e Ulhôa Cintra ao Anhangabaú, é interessante notar como estes parecem se opor radicalmente ao então finalizado jardim de Bouvard.

Enquanto a proposta de Bouvard propunha uma via sinuosa no fundo do vale, priorizava as áreas verdes em detrimento das construídas e buscava estabelecer uma relação visual sobretudo no sentido transversal ao vale (vide a implantação dos blocos gêmeos defronte ao Teatro Municipal), a proposta de Prestes Maia e Ulhôa Cintra invertia esta lógica, posicionando o observador no sentido longitudinal do vale, reduzindo as áreas ajardinadas e alargando e retificando a via motorizada. Ainda a proposta de 1930 considerava e valorizava duas altíssimas torres nos dois extremos do vale do Anhangabaú, limitando-o em seu sentido longitudinal e lhe conferindo um caráter de recinto.

Contudo, apesar destas significativas diferenças entre os dois projetos, é latente como do ponto de paisagístico ambas propostas se apoiam na mesma ideia de contemplação de uma ordem do mundo ${ }^{18}$, seja ela mais ou menos construída. É como se, partindo da noção de restituição da natureza perdida elaborada por Jochim Ritter, a paisagem do Vale do Anhangabaú, independentemente de sua forma, desempenha-se para os paulistanos do primeiro quartil do século XX a dupla função de transmitir intuitivamente uma imagem de civilização e uma ordem harmoniosa do cosmos.

17 - Estudo de um Plano de Avenidas para a Cidade de São Paulo, Francisco Prestes Maia e João Ulhôa Cintra 18 - Conforme J. Ritter, Paisagem: sobre a função do estético na sociedade Moderna, in Filosofia da Paisagem: uma antologia 
fig.16 Ville de l'Avennir, Eugene Henard, 1911

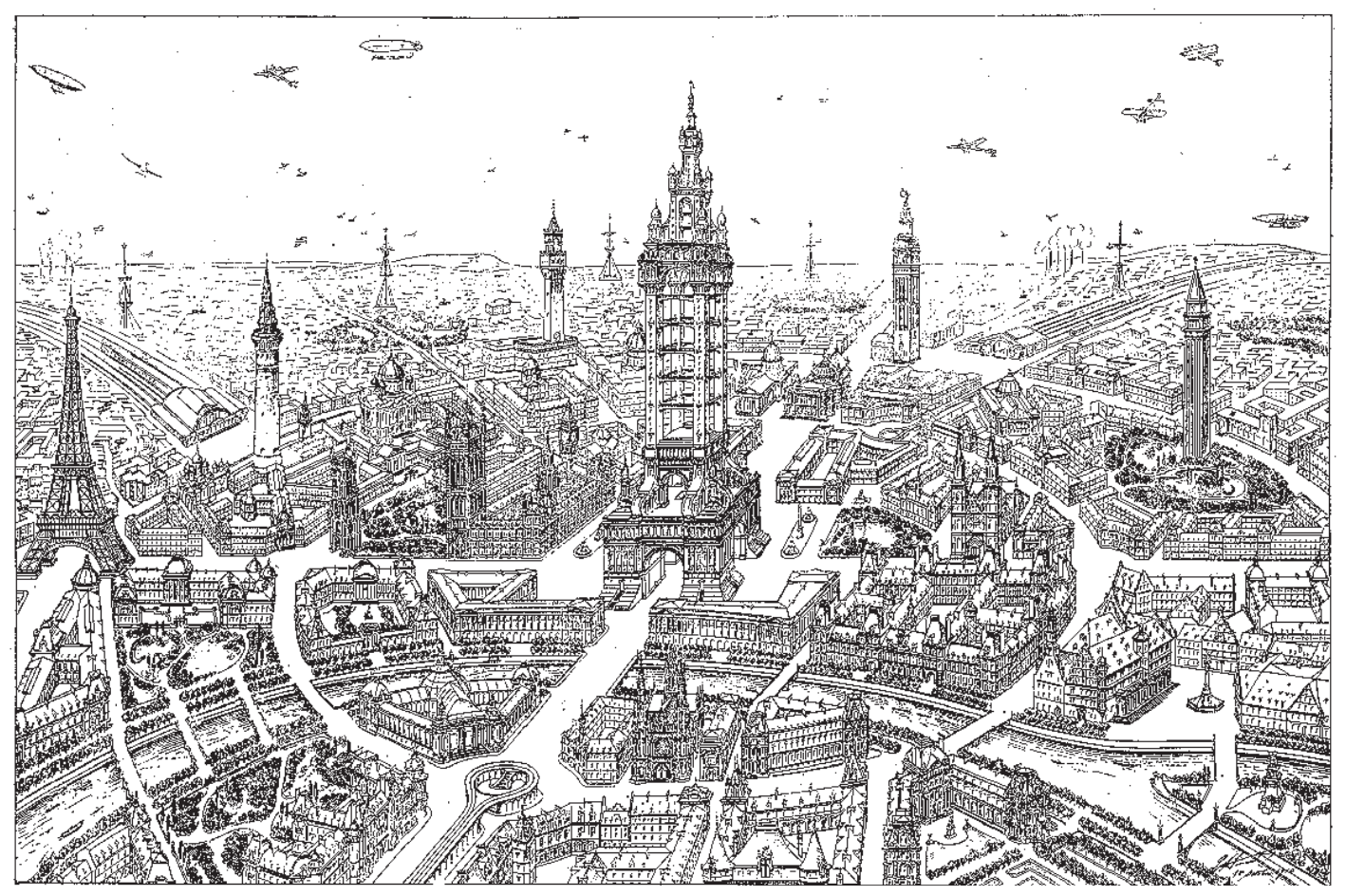

fig.17 Sampaio Moreira, 1926

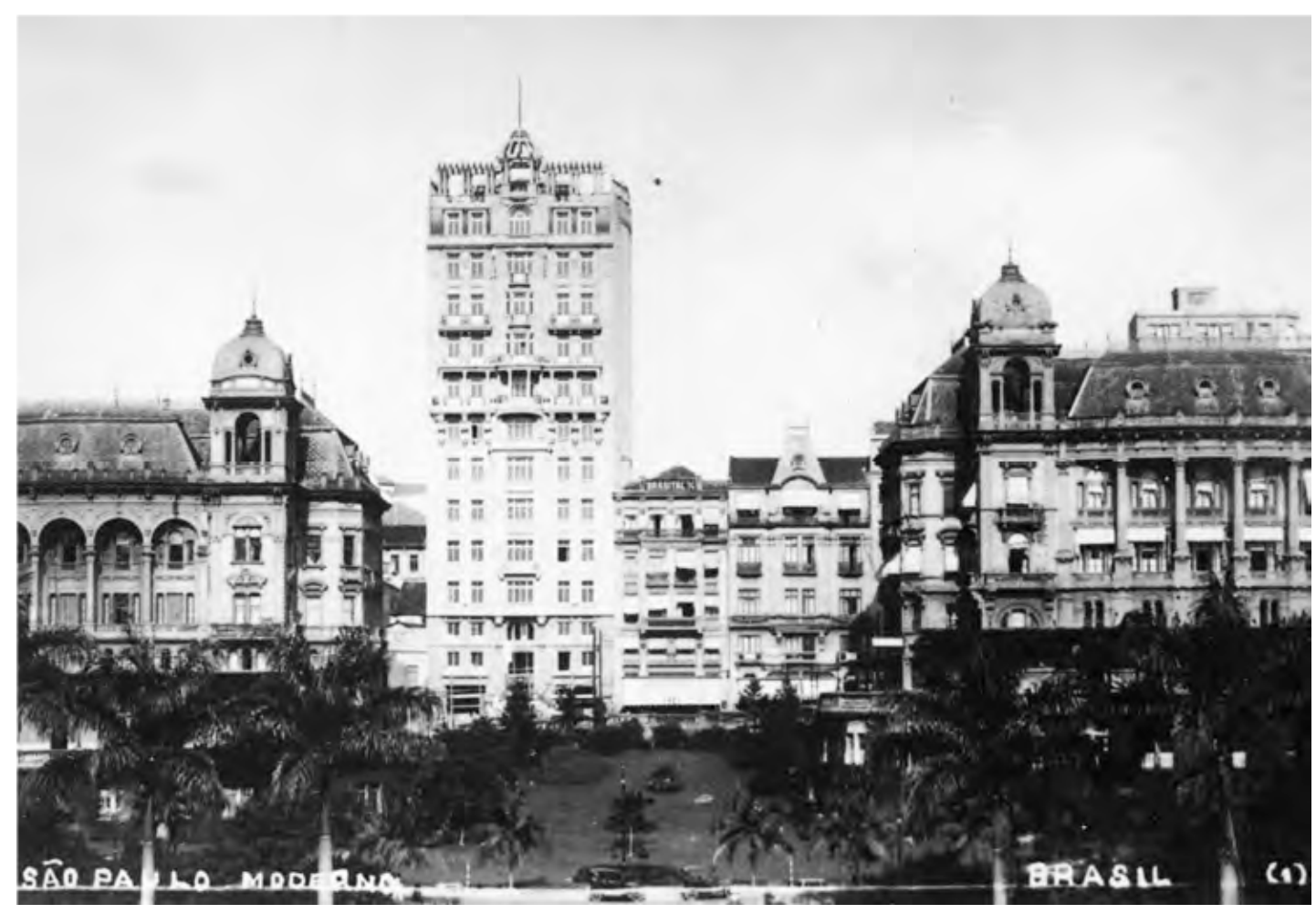

Reurbanização do Vale do Anhangabaú: propostas para recriação de uma paisagem 


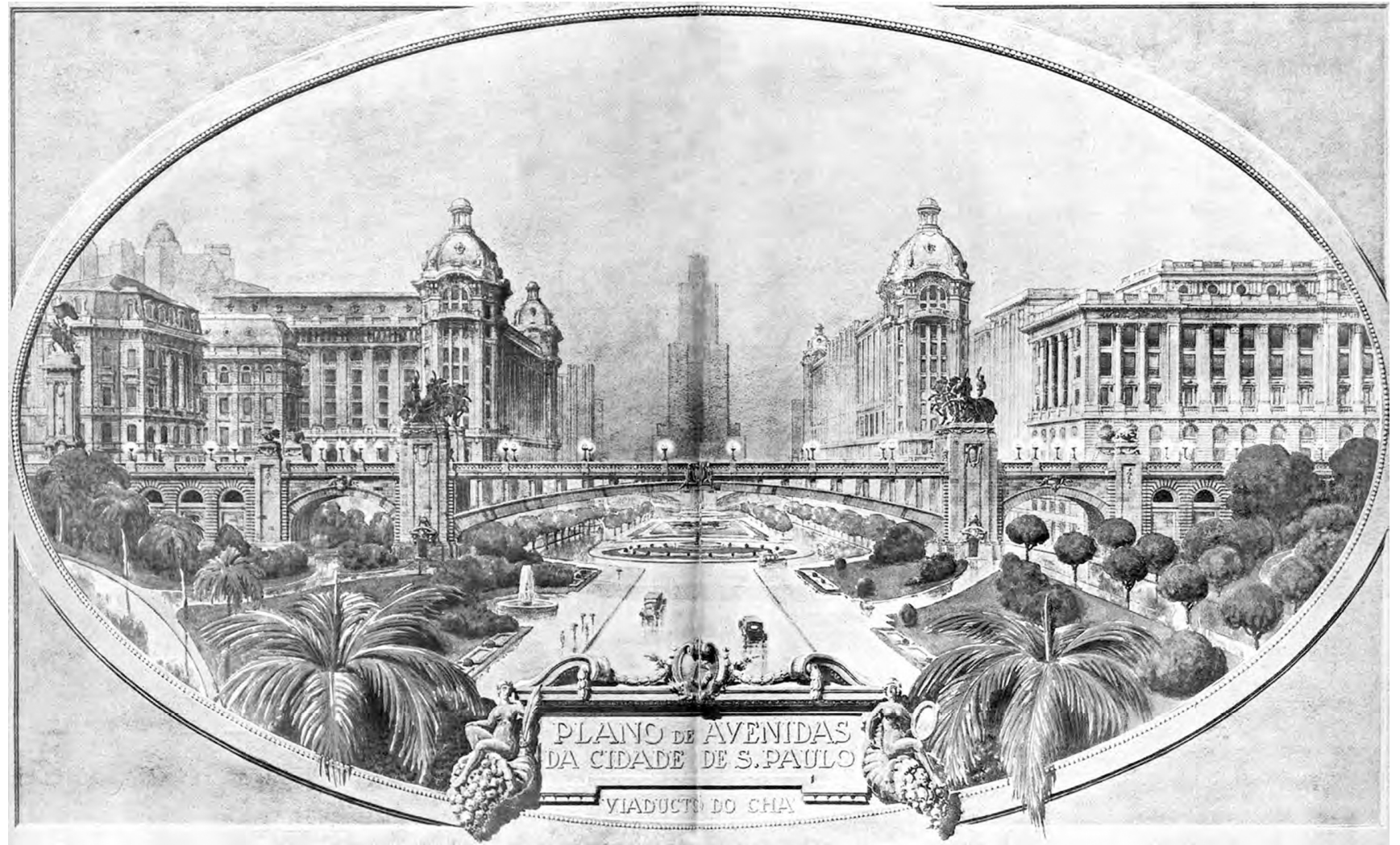

fig.18 Ilustra-

ção Pano de

Avenidas, 1930

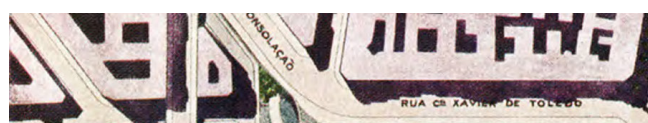

$1=1$

Jid

9 4 in 450

A)

翼

nos ande

Avenidas, 1930 


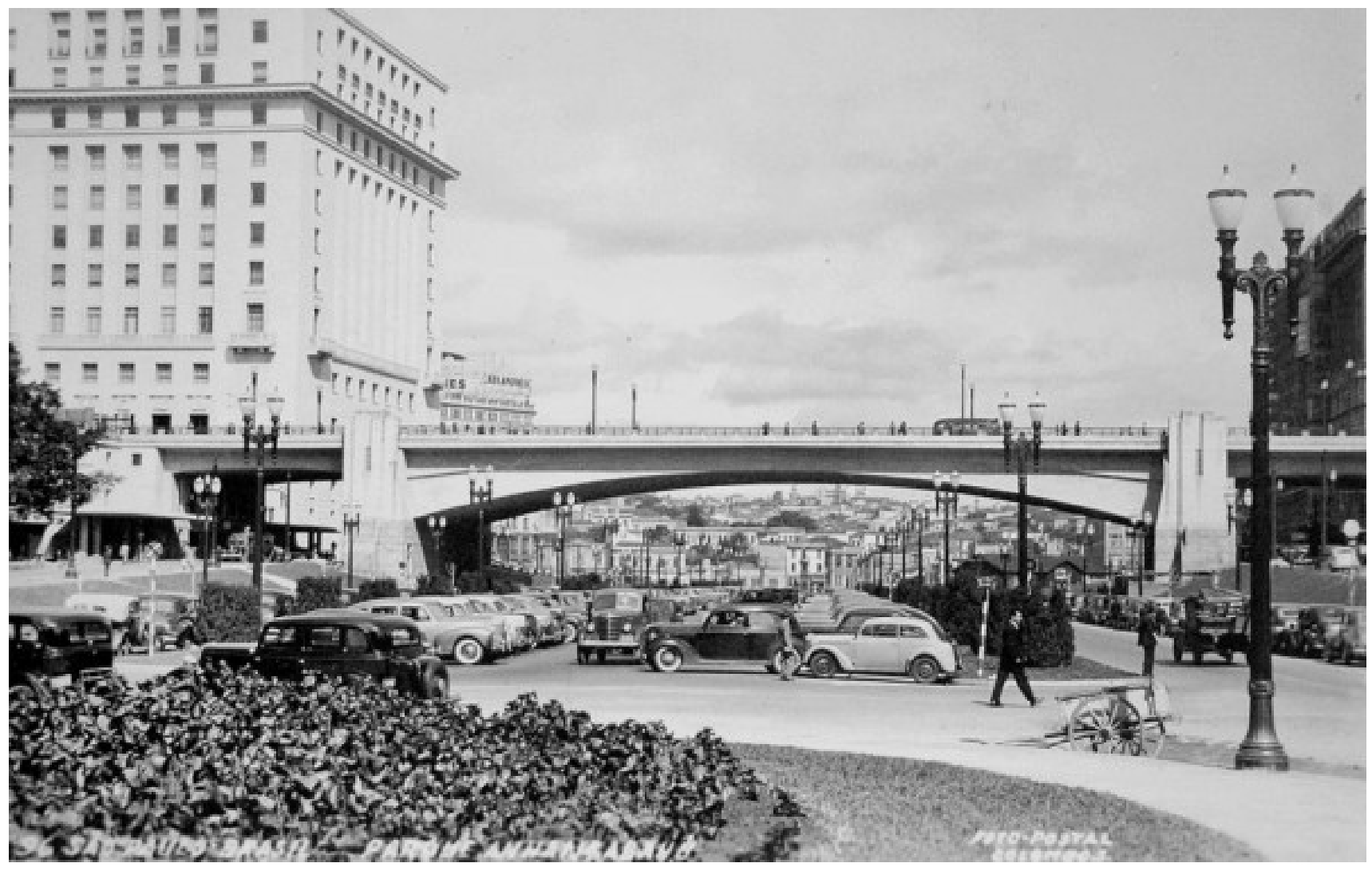

fig.20 Viaduto

do chá, década de

1940

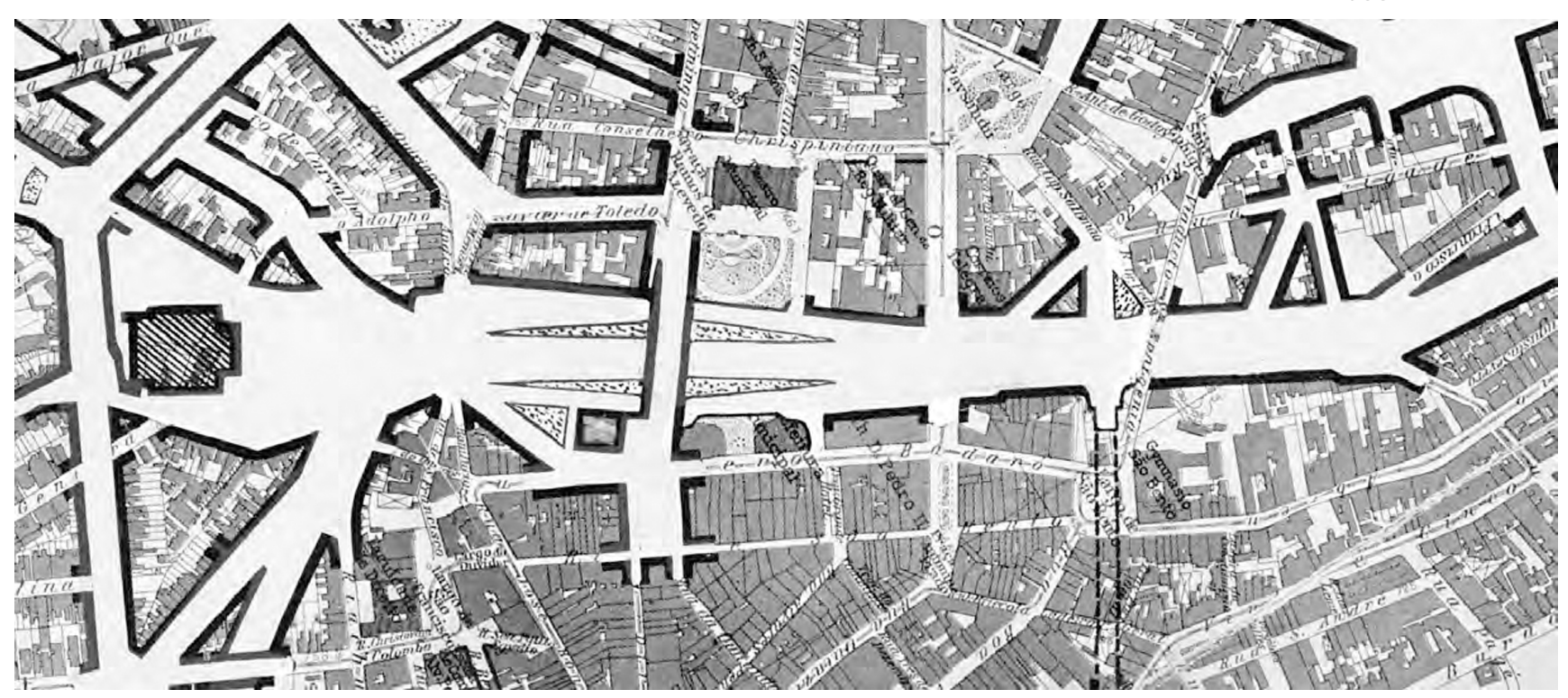

Reurbanização do Vale do Anhangabaú: propostas para recriação de uma paisagem 


\section{Da paisagem estática a passagem dinâmica}

Mas apesar da larga aceitação pública do "Plano de Avenidas", graças a Revolução ${ }^{19}$ que se deflagrou naquele ano, o plano de Prestes Maia e Ulhôa Cintra somente começaria a ser implantado em 1938, ano em que Maia assumiria a prefeitura de São Paulo e onde permaneceria até 1945.

Ao longo destes sete anos e meio à frente da prefeitura, Prestes Maia teve a oportunidade de implantar boa parte de seu plano inicial, todavia não sem reconsiderar algumas de suas posições projetuais. Como destaca Hereñu é abandonada a ideia de parque ou de recinto fechado que havia se pensado para o local. "O Anhangabaú agora se assumia como coração do "Y" e seu caráter de passagem se expressava claramente através da implantação de uma grande avenida no fundo do vale. Não há mais jardins nem rotatórias. Há apenas canteiros e ilhas de separação do tráfego"20

Muito é difundida a ideia de que tal guinada no desenho urbano de São Paulo deva-se sobretudo a questões de ordem prática e econômica, uma vez que a cidade enfrentava graves problemas de mobilidade urbana e que a solução por matriz rodoviária era vista como a de maior facilidade e agilidade de implantação. Esta é com certeza uma das interpretações possíveis e válidas, porém não podemos deixar de lado o peso que a cultura e a arte tiveram sobre tal processo.

Entre as diversas influencias advindas do campo da arte, podemos destacar o cinema como uma das principais fontes de novos valores e padrões estéticos para os paulistanos neste período. Foi durante as décadas de 1930 e 1940 que se proliferaram o nú19 - A Revolução de 1930 foi o movimento armado, liderado pelos estados de Minas Gerais, Paraíba e Rio Grande do Sul, que culminou com o golpe de Estado, o Golpe de 1930, que depôs o presidente da república Washington Luís em 24 de outubro de 1930, impediu a posse do presidente eleito Júlio Prestes e pôs fim à República Velha

20 - Hereñu, Pablo Emílio. Sentidos do Anhangabaú. Dissertação de Mestrado, FAUUSP, 2007. P. 187 
mero de salas por toda a cidade, tornando-se não só mais numerosas como também maiores. "O paulistano frequenta assiduamente os cinemas. É de praxe. Crianças, moças, velhos, homens, casais. Há filmes para gostos e idades diferentes. Gangsters e cowboys para os homens; romances arrebatadores para as mulheres. Exotismo para todos, no centro ou nos bairros tradicionais" (SIMÕES, 1990), e com ele cristalizava-se uma nova forma de imaginar a cidade e de enxegar sua paisagem.

Além do cinema, podemos ainda colocar como grande contribuinte deste processo de reinterpretação do Vale do Anhangabaú outro campo da arte, neste caso a Arquitetura e o Urbanismo moderno, sobretudo quando consideramos a proposta que Le Corbusier desenvolvera para São Paulo durante a sua passagem por aqui em 1929.

Nesta proposta ${ }^{21}$ Le Corbusier lança a ideia de sobre-correr de forma desimpedida o espaço da capital valendo-se para isso de "autoestradas de grande penetração“. Esta ideia, apesar de seu gigantismo utópico, parece ter encontrado solo fértil no imaginário paulistano, sendo resumida da seguinte forma nas palavras de Mário de Andrade:

"Corbusier baseia todas as suas deduções num plano intelectual: é por causa da vida ser assim que a cidade tem que ser assado, é por causa do homem ser assim que a casa dele tem que ser assado. Por isso quando partindo desses princípios lógicos de ordem intelectual, ele tira as suas ilações imaginativas, São Paulo toda feita de viadutos habitáveis por debaixo (...), tudo isso nos comove vivificadoramente. (...) estamos entrados diretamente no sonho, que pode ser um impossivel, mas é sonho sonhado, profundamente ativo, como esse em que a gente dá pinotes na cama, bufa, chora, esmurra espaços e acorda suado. (...). É um impossível, é irrealizável, será tudo o que quiserem mas é dum lirismo profundamente real, profundamente a Terra e a vida. "22

Em continuidade às propostas lançadas por Prestes Maia, na virada dos anos 50 seriam realizadas duas das obras que concretizariam o novo espírito pretendido para

21 - "Façamos o seguinte: de colina a colina, de um pico a outro, vamos implantar uma via horizontal de 45 quilômetros e em seguida uma segunda via, formando mais ou menos um ângulo reto, para servir os demais pontos cardeais. Estas vias retas são auto-estradas de grande penetração na cidade e, na realidade, realizam uma grande travessia. Os senhores não sobrevoarão a cidade com seus automóveis, mas a 'sobre-correrão'. Essas auto-estradas que proponho são viadutos imensos. Não construam arcos onerosos para sustentar os viadutos, mas sustentem-nos por meio de estruturas de concreto armado que constituirão escritórios no centro da cidade e moradias na periferia. A área desses escritórios e moradias será imensa e a valorização, magnífica. Um projeto preciso, um decreto. Operação já descrita. ", Le Corbusier, Precisões sobre um estado presente da arquitetura e do urbanismo. São Paulo: Cosac \& Naify, 2004

22 - Mario de Andrade, "Cidades", in Taxi e Crônicas, Diário Nacional 1 de maio de 1931 


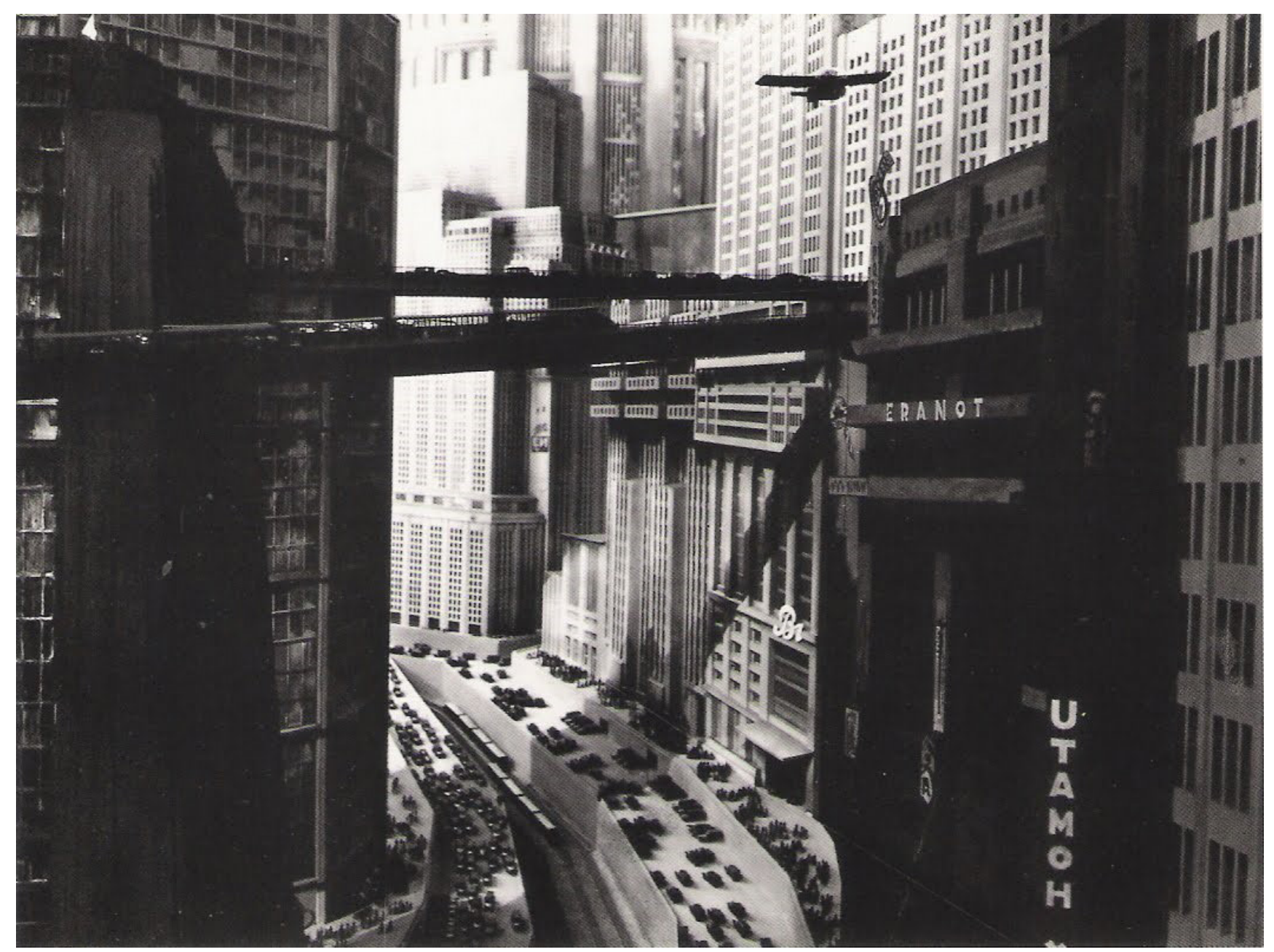

fig.22 Cena do filme Metropolis, de

Fritz Lang, 1927 


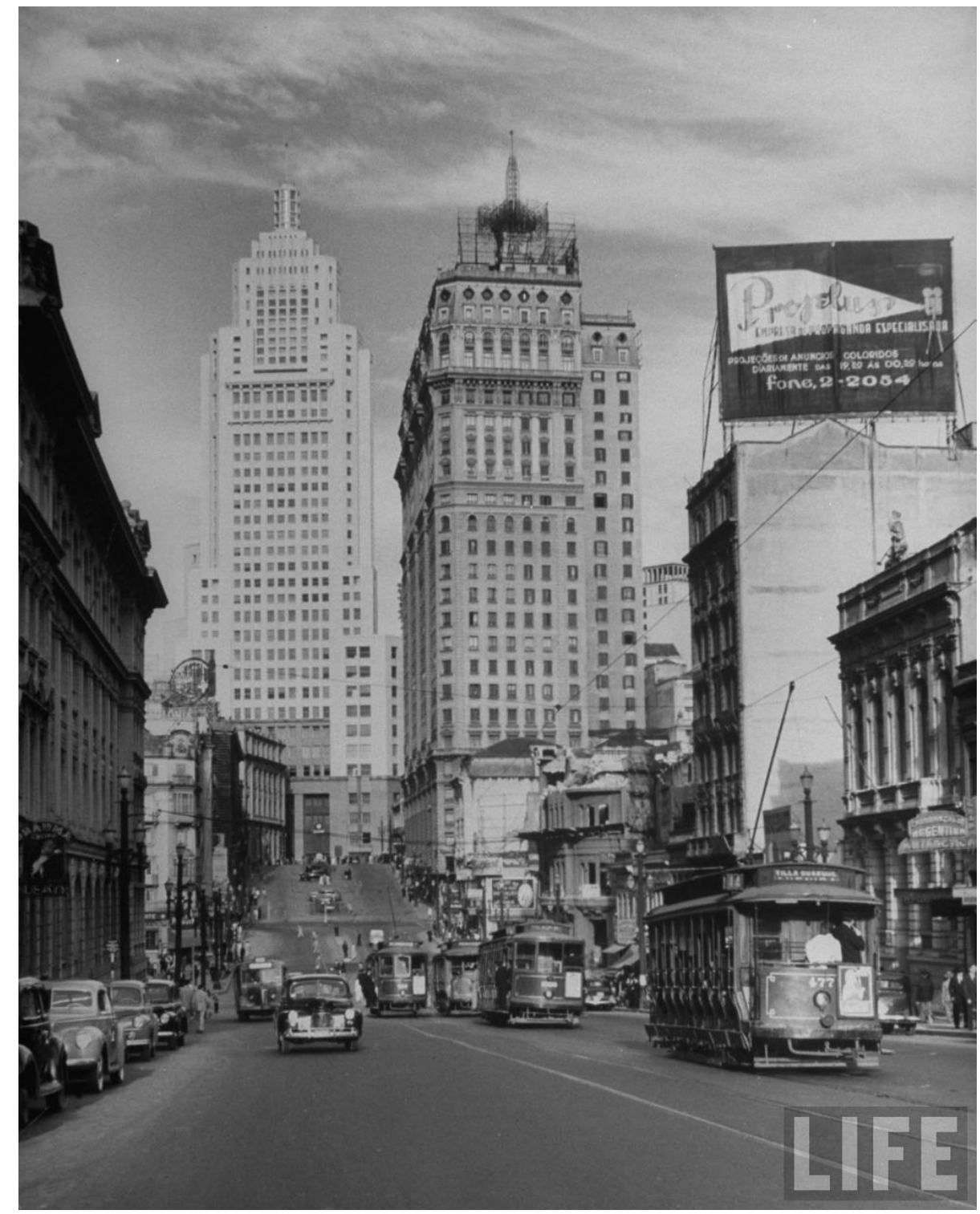

fig.23 Aveinida São João década de 1930 - Dmitri Kessel, acervo revista Life 


\section{Da Passagem à Concorrência}

o espaço do Vale do Anhangabaú. Em 1947, mesmo ano da inauguração da Torre do Banespa, seria iniciada a demolição do Edifício do Cinema Central e Delegacia Fiscal, situado no encontro entre avenidas São João e Anhangabaú. Dois anos após iniciar-se-iam as obras da passagem subterrânea que evitaria o cruzamento dos prolongamentos destas duas avenidas. A esta passagem, realizada pela prefeitura durante a gestão de Asdrúbal Cunha, apelidou-se de "Buraco do Ademar" em homenagem ao governador do estado Ademar de Barros.

Com estas obras o Vale se ressignificava, finalmente, de forma plena. Por um lado, deixaria para trás seus contornos de espaço definido em meio à região central para se tornar um meio, um entre, uma conexão entre regiões norte e sul da cidade - o vale tornava-se vau; e por outro abriria mão de sua capacidade de promover encontros, potencializados por seus usos e formas (esquinas, calçadas, cinemas) para visar, de forma mais eficiente possível, o bom funcionamento e o fluxo contínuo da cidade. Ao longo dos anos 50 transformar-se-ia também a maneira de se acessar e percorrer o Vale e de toda a região central de São Paulo, fato, que para além de suas consequências técnicas e econômicas, resultaria em transformações significativas na forma de se relacionar e vivenciar o espaço urbano. Com a desativação do sistema de bondes municipais em 1949, veremos que nos anos seguintes a multiplicação do número de linhas de ônibus movidos à diesel, os quais a princípio seriam geridas pela municipalidade, mas, porém, devido às dívidas provenientes dos grandes investimentos nas 
áreas de infraestrutura ${ }^{23}$, acabaram por ser monopolizados por grupos privados ${ }^{24}$. Ainda neste período, notaremos o aumento de $500 \%$ da frota de automóveis particulares $^{25}$, fato impulsionado pela instalação da indústria automobilística no Brasil a partir de 1945. Com isso, o "ir à cidade" tornava-se paulatinamente "percorrer a cidade". Neste sentido, o relato de Marcos Acayaba é uma boa ilustração:

"Quando eu era menino, um dos passeios preferidos era "dar uma volta na cidade". Assim era como todos se referiam ao centro de São Paulo. Saímos, de carro, do nosso bairro na Zona Sul, Congonhas, e pela avenida Nove de Julho chegávamos à cidade. Percorríamos o Vale do Anhangabaú: os grandes edifícios, os viadutos, as palmeiras imperiais e o Teatro Municipal. Sucessão magnifica desfrutada em movimento. ${ }^{{ }^{26}}$

Porém, como poder-se-ia imaginar, o crescimento exponencial do número de veículos somado ao crescimento populacional verificado em São Paulo nas décadas de 1950 e $1960^{27}$, resultaria por congestionar todo o sistema idealizado por Prestes Maia duas décadas antes. Se durante a década de 1950 percorria-se a cidade, poderíamos dizer que vinte anos depois, conforme anunciado pelos jornais da época, concorria-se pela cidade. O início dos anos de 1970 trariam ainda alguns duros golpes à autoestima e aos sentimentos ufanistas brasileiros da década anterior. Em 1971 o milagre econômico brasileiro começara a demonstrar desgaste, até que em 1974, motivado pela crise do petróleo, foi registrado o primeiro déficit na Balança Comercial Brasileira desde $1950^{28}$.

23 - Em palestra concedida por Prestes Maia sobre "Os Melhoramentos de São Paulo" em 1945, o então prefeito enumera as seguintes obras recém-concluídas ou em andamento: O Estádio do Pacaembu, A Biblioteca Mario de Andrade, a Ponte Grande, as avenidas Ipiranga, Vieira de Carvalho e Senador Queiroz, Anhangabaú, Duque de Caixias e o prolongamento das avenidas Paulista, Pacaembu, Nove de Julho e Rebouças; as praças do Carmo, Charles Miller, Consolação e João Mendes; o alrgamento da rua liberdade; os viadutos Jacareí, Dona Paulina e Nove de Julho; as pontes Mercúrio, Indústria e Pequena; a cabalização do $3^{\circ}$ e $4^{\circ}$ trecho do Tiête e do trecho final do Tamanduateí.

24 - Segundo Waldemar Correa Stiel (1978), entre 1947 e 1957 a frota de bondes em São Paulo diminuiu 68\%. Entre 1947 e 1954 a frota de ônibus à diesel aumentou 31\%, contando com 1172 veículos em 1954 contra apenas 80 trólebus no mesmo ano. É ainda neste período que vemos a inversão de porcentagem de passageiros transportados pela companhia municipal (CMTC) e companhias particulares: em 1949 75\% dos passageiros eram transportados pela CMTC, enquanto em 1963 apenas 19\% utilizavam este serviço. 25 - Ministério das Cidades, Departamento Nacional de Transito - DENATRAN - 2015

26 - Marcos Acayaba in ACAYABA, Marcos. Marcos Acayaba. São Paulo: Cosac Naify, 2007 p. 96 27 - Entre os anos de 1950 e 1960 a população do Município de São Paulo saltou de 2.198 .016 habitantes para 3.781.446, configurando uma taxa de crescimento de 5,6 na década. Entre os anos de 1960 e 1970 este ritmo diminuiria um pouco, caindo para uma taxa de 4,6. Em 1970 registrou-se uma população de 5.924.615 habitantes.

28 - FURTADO, Celso. Análise do “Modelo" Brasileiro, 1982, 7a edição, Editora Civilização Brasileira, Rio de Janeiro, “O verdadeiro milagre" -Trecho: “Em 1974 o volume físico das importações aumentou em 33,5 por 


\section{Da Concorrência ao Concurso}

Do ponto de vista do desenho do Vale do Anhangabaú notaremos que, em meio a este desencantamento da virada de 70, surgem uma série de projetos e intervenções para a requalificação de seu espaço. Se em um primeiro momento estas intervenções pretendiam-se exclusivamente obras funcionais, como por exemplo o viaduto Eusébio Stevaux (1968), a garagem da Praça da Bandeira (1969) e a passarela construída sob o Viaduto do Chá (1969) que visava "facilitar" a travessia de pedestres, notaremos que com o avanço dos anos estas começariam a sugerir transformações mais profundas no espírito do Vale e de toda a região central. É o caso por exemplo dos projetos realizados por Artigas em 1974 e das obras de pedestrianização encabeçadas pela EMURB a partir de 1975.

Contudo, apesar do grande número de projetos apresentados ao longo dos anos de $1970^{29}$, nenhuma das versões estudadas foi levada à frente pelo poder municipal. Tal desfecho, como aponta Hereñu (2007), deve-se em parte às vontades políticas fugazes da época ${ }^{30} \mathrm{e}$ em parte a falta de "uma linha clara de pensamento sobre a cidade". Dado este impasse e a pressão crescente por uma reformulação do Vale, no segundo semestre de 1980, sob determinação do Prefeito Reinaldo de Barros, a EMURB decento, enquanto o das exportações declinava em 1,4 por cento. $O$ saldo negativo da conta corrente da balança de pagamentos alcançou 7 por cento do PIB nesse ano".

29 - ablo Hereñu aponta ao menos nove projetos realizados entre 1971, ano de criação da EMURB, e 1979, ano que passaria a ser dirigida por Paulo Bruna. Dentre os projetos destacados pelo autor se encontram as propostas para Reformulação da Praça da Bandeira e Reformulação Viária e Paisagística, ambas realizadas em parceria pelos escritórios de Croce, Aflalo \& Gasperini e Figueiredo Ferraz em 1971; as passarelas realizadas pela Pluric em 1973; a proposta de reformulação viária e do sistema de transporte de Artigas de 1974; um novo sistema de travessias elevadas proposto pelo próprio corpo técnico da EMURB em 1975; a revisão do projeto de Artigas em 1976; uma alternativa subterrânea para a travessia de pedestres em 1977; e o Projeto Anhangabaú em 1979.

30 - Entre 1971 e 1979 São Paulo teve seis prefeitos nomeados: Paulo Maluf (1969-1971), José Figueiredo Ferraz (1971-1973), Brasil Vita (1973), Miguel Colassuono (1973-1975), Olavo Setúbal (1975-1979) e Reinaldo de Barros (1979-1982) 
senvolveria um projeto definitivo, uma espécie de síntese baseada em todas as experiências anteriores, intitulado "Projeto Anhangabaú".

Todavia, dado à resistência dos meios técnicos e populares às propostas apresentadas pela EMURB ${ }^{31}$, o Projeto Anhangabaú, antes de se tornar um desfecho para a desenho do Vale, tornar-se-ia a chave para o surgimento de mais uma etapa em seu longo processo de conformação. À semelhança do que ocorrera setenta anos antes em decorrência do embate entre as propostas de Silva Telles, Freire e Guilhem e Samuel das Neves, o poder público, encontrando-se incapacitado de tomar uma decisão final, viu-se forçado a convocar um agente "neutro e inquestionável" para tal juízo. Desta vez, porém, como veremos, tal responsabilidade não recairia sobre os ombros de um renomado arquiteto estrangeiro, mas sim da própria população.

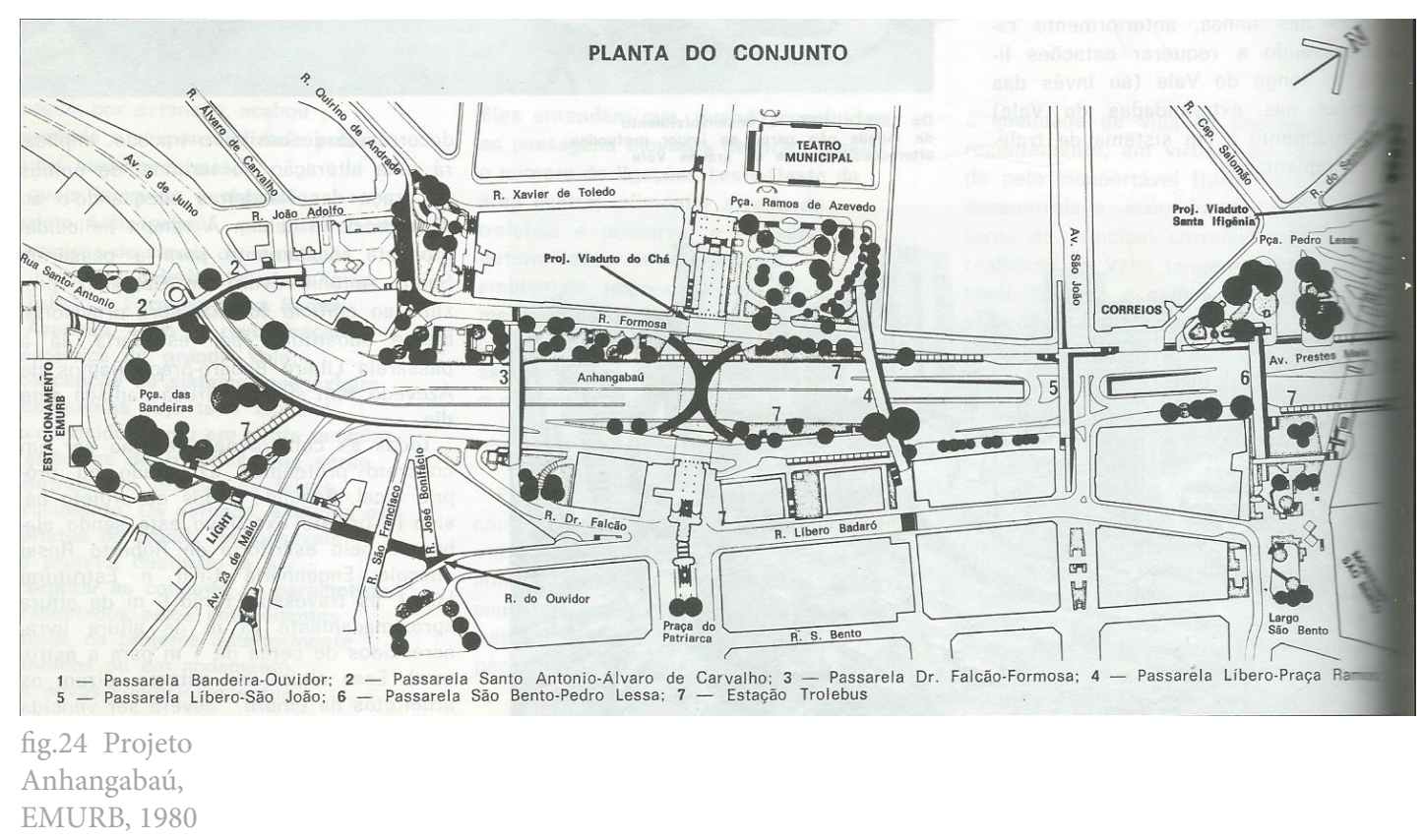

31 - Dentre as inúmeras críticas direcionadas à proposta da EMURB destacamos a do Professor Benedito Lima de Toledo e de Cesar B. Lourenço, então presidente do IAB, que diz: "(...)embora os arquitetos da Emurb sejam profissionais de alto nível, nos parece que forças inerentes ao projeto acabaram formulando um sistema imediatista. Ou seja: há atropelamentos em seis ponto do Vale do Anhangabaú, logo devem ser criadas seis passarelas, uma em cada local crítico e o problema está resolvido. (...) Uma solução pragmática como a que foi adotada, passa por cima do Vale do Anhangabaú como espaço característico, representativo, da cidade de São Paulo. "in A Construção São Paulo, n1707 p11. 


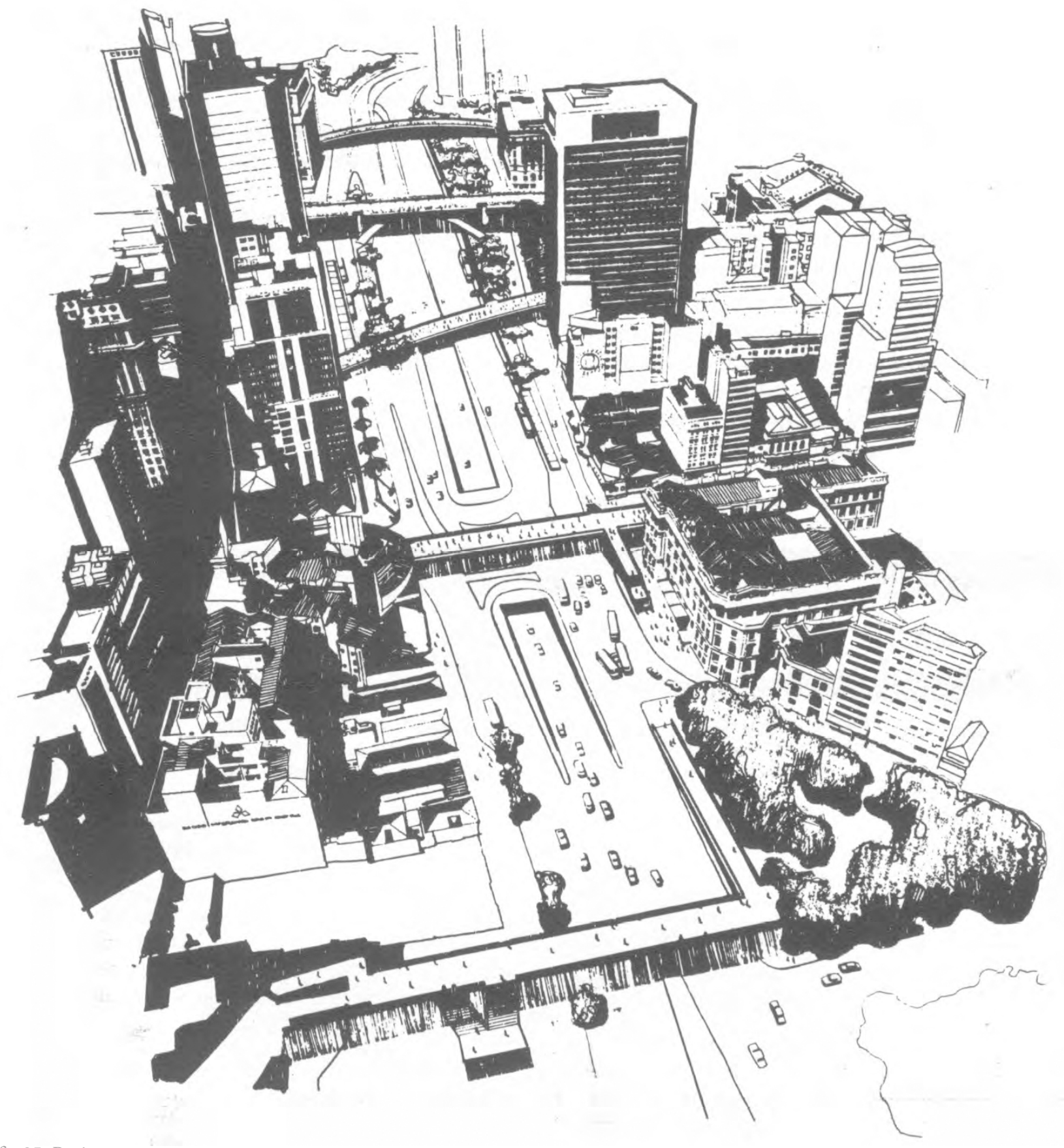

fig.25 Projeto

Anhangabaú,

EMURB 1980 


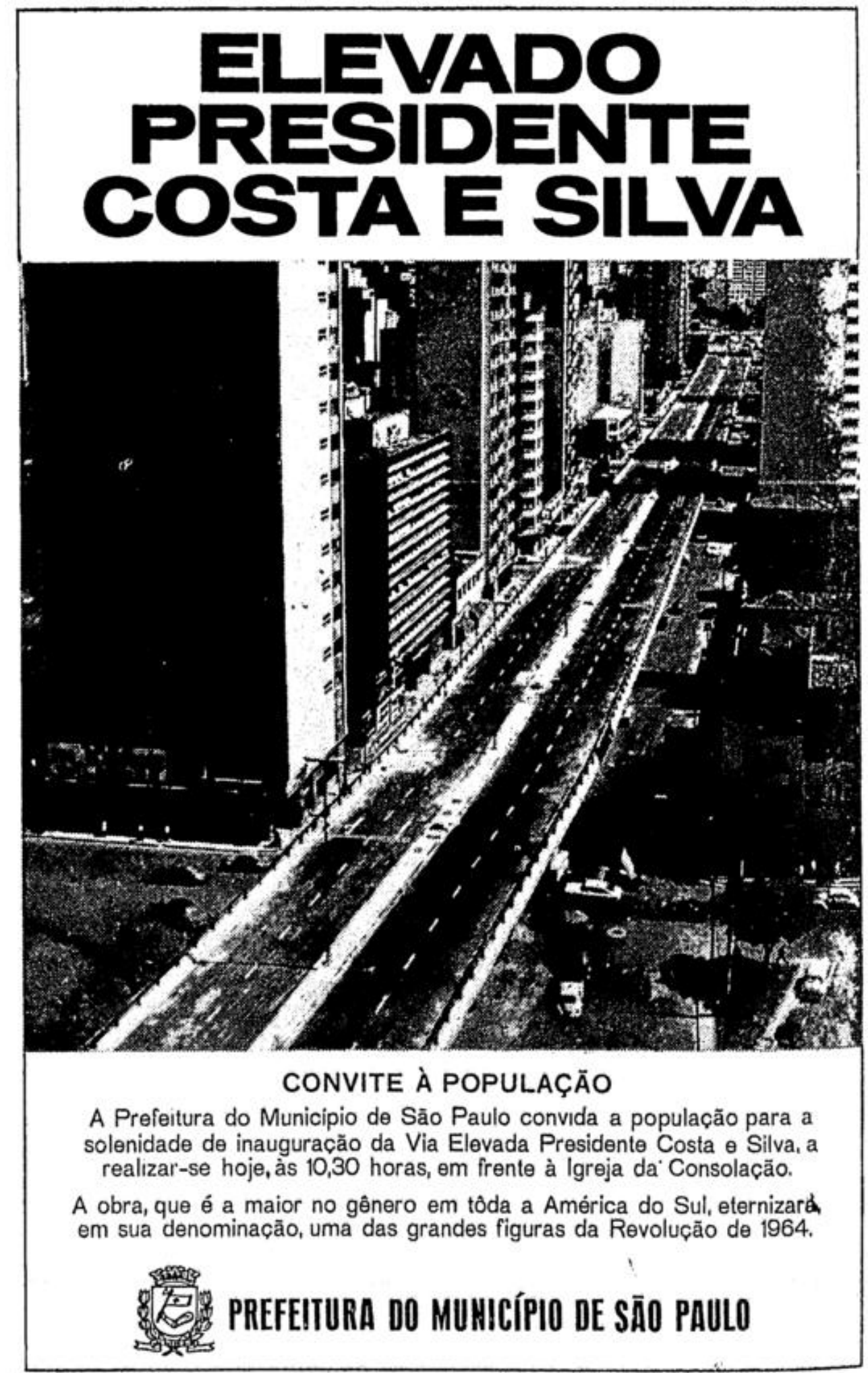

fig.26 Panfleto de inauguração Elevado Costa e Silva, 1971 


\section{Da organização do Concurso}

Promovido pela Prefeitura de São Paulo por meio EMURB e organizado em parceria com IAB-SP, o Concurso Público Nacional para Elaboração de Plano de Reurbanização do Vale do Anhangabaú foi realizado entre os meses de fevereiro e junho de 1981 e contou com um total de mais de mil profissionais inscritos das mais diversas especialidades ${ }^{1}$, distribuídos em cento e cinquenta e três equipes, das quais noventa e três entregaram suas propostas até a data limite e oito, entre menções e prêmios, foram destacadas.

Como apontado por Valéria Cássia Santos (2002), a este concurso cabe destacar não só sua importância do ponto de vista do número de inscritos e do significado desta área para cidade de São Paulo, mas também por anunciar a retomada dos processos públicos e a retomada da democracia no Brasil. Mais do que isso, viram-se questionadas neste Concurso não só as decisões do governo central da época, mas também, como veremos, as próprias bases de desenho e construção do espaço público urbano brasileiro.

\section{Antecedentes}

Como vimos anteriormente no Capítulo 1, a partir de meados da década de 1960, período que coincide com o aumento da carga viária e o surgimento dos primeiros problemas de circulação tanto para pedestres quanto para automóveis, o Vale do Anhangabaú passa a ser objeto de uma profusão de propostas e estudos realizados por diferentes arquitetos e companhias especializadas. Via de regra, salvo algumas exceções, estes trabalhos dos anos 60 e 70 visavam em maior ou menor grau sanar 1 - A construção São Paulo, n. 1741, p. 05 
três problemas fundamentais: a travessia de pedestres entre as encostas leste e oeste do Vale, a circulação de veículos no sentido norte-sul-norte e o disciplinamento e distribuição do transporte público na região.

Todavia, apesar das diversas propostas apresentadas, coube à EMURB apresentar em outubro de 1980 aquele que seria o derradeiro (e possível) projeto para a região do Vale do Anhangabaú: o Projeto Anhangabaú

Desenvolvido por quase dois anos dentro da Empresa Municipal de Urbanismo e se apoiando na experiência acumulada dos projetos anteriores ${ }^{2}$, o Projeto Anhangabaú buscava por meio da proposição de seis novas passarelas ${ }^{3}$ solucionar a questão das travessias de pedestre e com isso reduzir o número de atropelamentos e, por conseguinte, melhorar a fluidez do trânsito de automóveis na área central da cidade. Ainda, para além destes motivos de ordem prática, o projeto apresentado pela EMURB pretendia implantar um novo sistema de trólebus na região, reintegrar o canteiro de obras da estação Anhangabaú do Metrô e, de forma mais ampla, recuperar a paisagem do Vale como um todo.

Para seus autores ${ }^{4}$ a realização de passagens aéreas apresentava-se como a melhor alternativa para o Vale pois além de atender de maneira eficiente as principais necessidades e pontos de travessia, possibilitava a execução da obra dentro do caráter de urgência exigido e ainda se adequaria a questão do custo implantação. Não menos importante, a opção por passagens áreas em detrimento de passagens subterrâneas dispensaria a readequação de toda a rede enterrada no leito do Vale, tal como o riacho canalizado, as galerias de água pluvial, as redes de telefone e eletricidade, etc.

Em entrevista concedida em agosto de 2014 Paulo Bruna, Diretor de Planejamento da EMURB à época, diz:

\footnotetext{
2 - Para maiores informações dos projetos previamente desenvolvidos pela EMURB nos anos de 1970 recomenda-se a leitura do capitulo "Uma década de indecisões da EMURB" da dissertação de mestrado de Pablo Hereñu, FAUUSP 2007

3 - As seis novas passarelas, de norte a sul, são: São Bento-Pedro Lessa; Libero Badaró-São João; Libero Badaró-Praça Ramos de Azevedo; Doutro Falcão-Formosa; Santo Antônio-Álvaro de Carvalho e Bandeira-Ouvidor 4 - O Projeto Anhangabaú foi realizado dentro dos escritórios da EMURB e, portanto, contou com a colaboração de muitos profissionais. Porém dentro deste processo podemos destacar o papel do arquiteto Paulo Júlio Valentino Bruna, Diretor de Planejamento, e dos arquitetos Domingos Theodoro de Azevedo Netto e Paulo Sergio de Souza.
} 
"A ideia de realizar a travessia de pedestres por passagens subterrâneas sempre existiu, mas nós optamos pelas passarelas aéreas por bom senso: nós não tínhamos verbas nem tempo disponivel para realizar uma obra deste tipo"

Todavia, apesar destas virtudes e razões elencadas pelos técnicos da EMURB, tão logo o projeto fora apresentado à população um forte debate público começou a formar-se. Alvo de duras críticas, já na edição de 27 de outubro de 1980 da revista A Construção São Paulo é possível ver que não havia consenso sobre este projeto mesmo dentro do meio técnico e as opiniões se dividiam entre "uma solução necessária", "pragmática" "possível" e "preferível”.

Contudo, não é nos veículos de comunicação técnicos que surgem as críticas mais arrasadora. Em um texto publicado no mês de novembro no Jornal da Tarde, o Professor e Arquiteto Benedito Lima de Toledo, chama a atenção para o fato daquela proposta tornar irreversível a transformação do outrora Parque do Anhangabaú, conectado em seu início à Praça Ramos de Azevedo e ao Largo da Memória, em um canal de circulação e escoamento viário. Ainda Lima de Toledo defende que "cruzando o vale como um cordão de sapatos", perder-se-ia também a perspectiva de todo o conjunto do Vale, e consequentemente uma parte importante do patrimônio arquitetônico paulistano. Sendo assim ele propõe que um concurso público de arquitetura seja organizado para encontrar-se outra solução, mais coerente e harmônica com o espaço do Vale. Dada a repercussão do artigo, ainda no mês de novembro, ou seja, a menos de trinta dias após sua divulgação, o então prefeito de São Paulo Reynaldo de Barro suspende o segmento do Projeto Anhangabaú e acata a sugestão de Lima de Toledo.

Porém, se com a decisão pela realização do Concurso o prefeito Reynaldo de Barros imaginava poder apaziguar os ânimos e postergar questão de reforma do Vale para o futuro, devemos notar que esta decisão teve efeito contrário, acarretando na verdade no incentivo à participação de parcelas significativas da população paulistana na discussão sobre o tema. Fato é que a alternativa lançada por Lima de Toledo encontrou um solo muito fértil dentro da mentalidade e do cenário político paulistano da época. Como é possível observar a partir da leitura da coluna "O vale em discussão" publicada pela Folha de São Paulo entre dezembro de 1980 e março de 1981, havia por um lado um desejo muito forte para a redemocratização dos processos de deci- 
são e, por outro, um sentimento de não representatividade nas ultimas grandes obras urbanas realizadas na cidade de São Paulo, notoriamente o Elevado Costa e Silva e a Praça Roosvelt, ambas realizadas pelo então Governador e responsável pela indicação do então prefeito Reynaldo de Barros, Engenheiro Paulo Maluf.

\section{Anhangabaú: reorganização do espaco é colocada em debate}

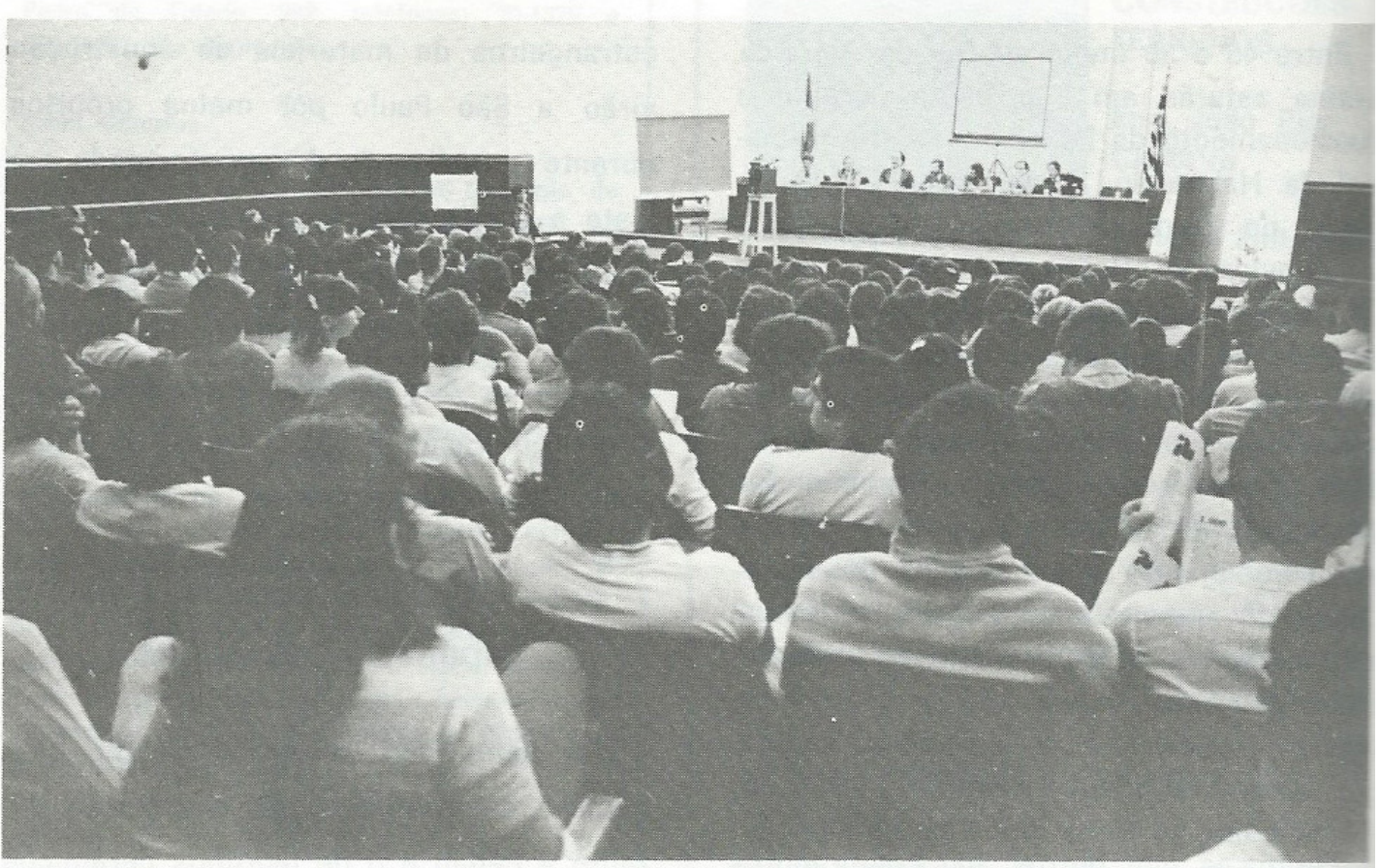

As discussões em torno da reurbanização ao Vale do Anhangabaú atrairam expressivo número de participantes ao encontro 


\section{A organização do Concurso:}

Ainda em dezembro de 1980 começam os preparativos para a realização do Concurso. As primeiras determinações cumpridas pela EMURB foram a contratação do arquiteto e professor Benedito Lima de Toledo para exercer a função de Arquiteto Consultor e do IAB-SP para organização e gestão do Concurso.

Realizadas estas contratações cada parte se incumbiu de uma tarefa. À EMURB, entidade promotora e detentora de grande acervo cartográfico e penetração dentro das secretarias municipais, coube a reunião das plantas e informações relativas à topografia, cotas de nível, infraestrutura e instalações presentes e projetos futuros previstos para o Vale.

Coube também à EMURB a realização do Edital do Concurso, do qual podemos destacar os seguintes objetivos:

A elaboração de solução global para o conjunto urbanístico do Vale do Anhangabaú A resolução da circulação viária e de pedestre, o uso dos espaços públicos, equipamento em nível local e metropolitano, disciplina e regulamentação de uso do solo e das edificações, valorização dos edifícios tombados pelos poderes públicos ou considerados de zona especial

Proposta com vista a implantação gradual da seleção, especificando claramente os elementos de uma intervenção imediata.

Ao IAB-SP, estavam atribuídas a produção e edição do material gráfico a ser entregue aos concorrentes (edital, pranchas, informes, etc), bem como a divulgação, inscrição e recebimento dos trabalhos. Ao IAB-SP ainda recairia a tarefa de organização e realização de Seminários e Grupos de Trabalho abertos à toda a comunidade, ideia que se originou nas reuniões internas desta instituição.

Já ao Arquiteto Consultor coube a reunião e organização dos dados históricos, iconográficos e a redação do Programa (termo de referência) do Concurso.

Quanto a indicação dos cinco membros da comissão julgadora esta recairia sobre a EMURB sendo que três deveriam pertencer ao corpo de jurados do IAB e, no mínimo, dois deveriam ser do departamento de São Paulo. 


\section{CONCURSO PÚBLICO}

\section{VALE DO \\ ANHANGABAÚ}

\section{PMSPP PREFEITURA DO MUNIIIPIO dE SÃO PAULO}

EMÚRB EMPRESA MUNICIPAL dE URBANIzAGāo

IAB INSTITUTO DE ARQUITETOS DO BRASIL 


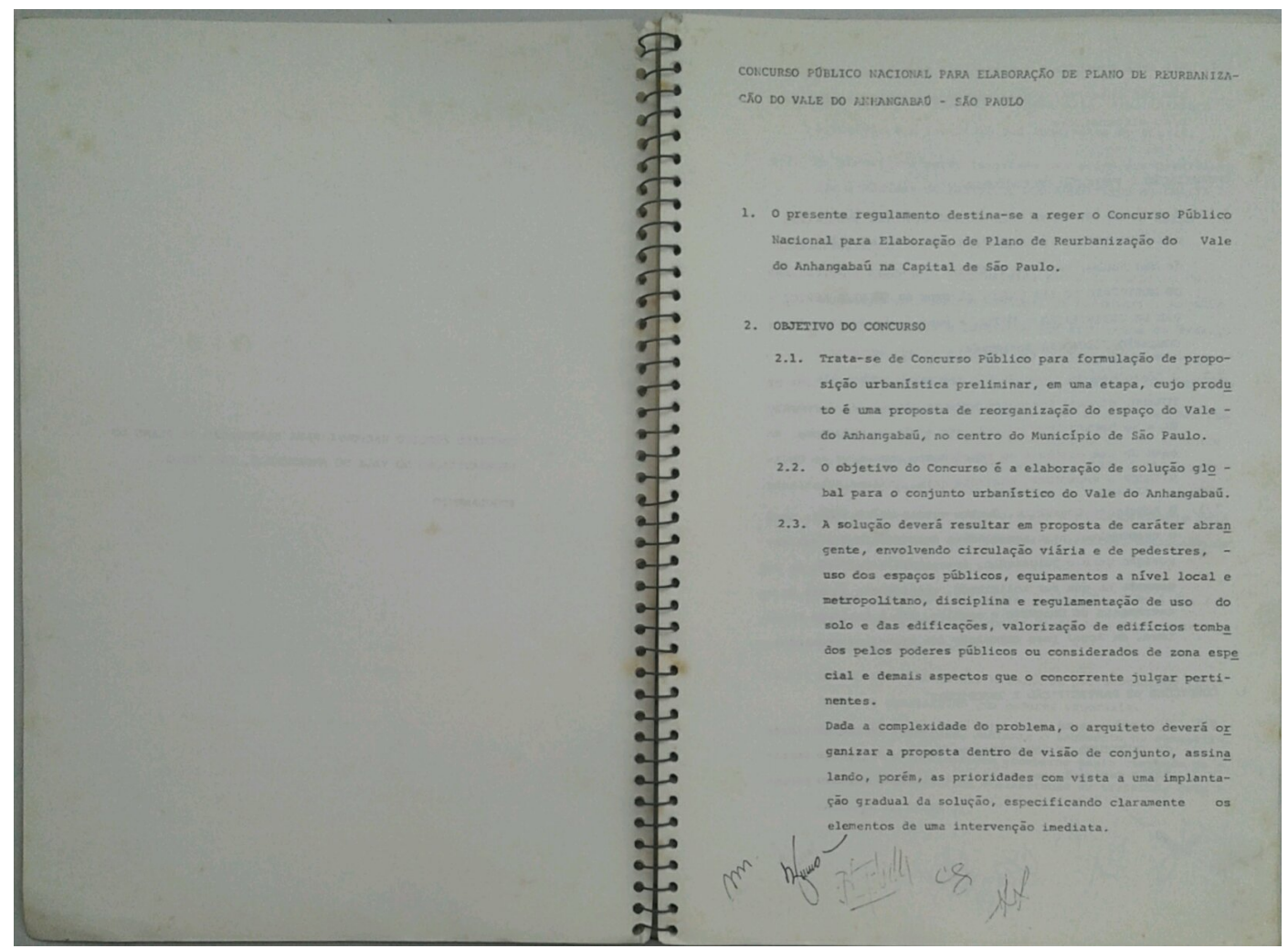

fig.29 Reprodução Edital e Programa do Concurso, acervo IAB, 1981

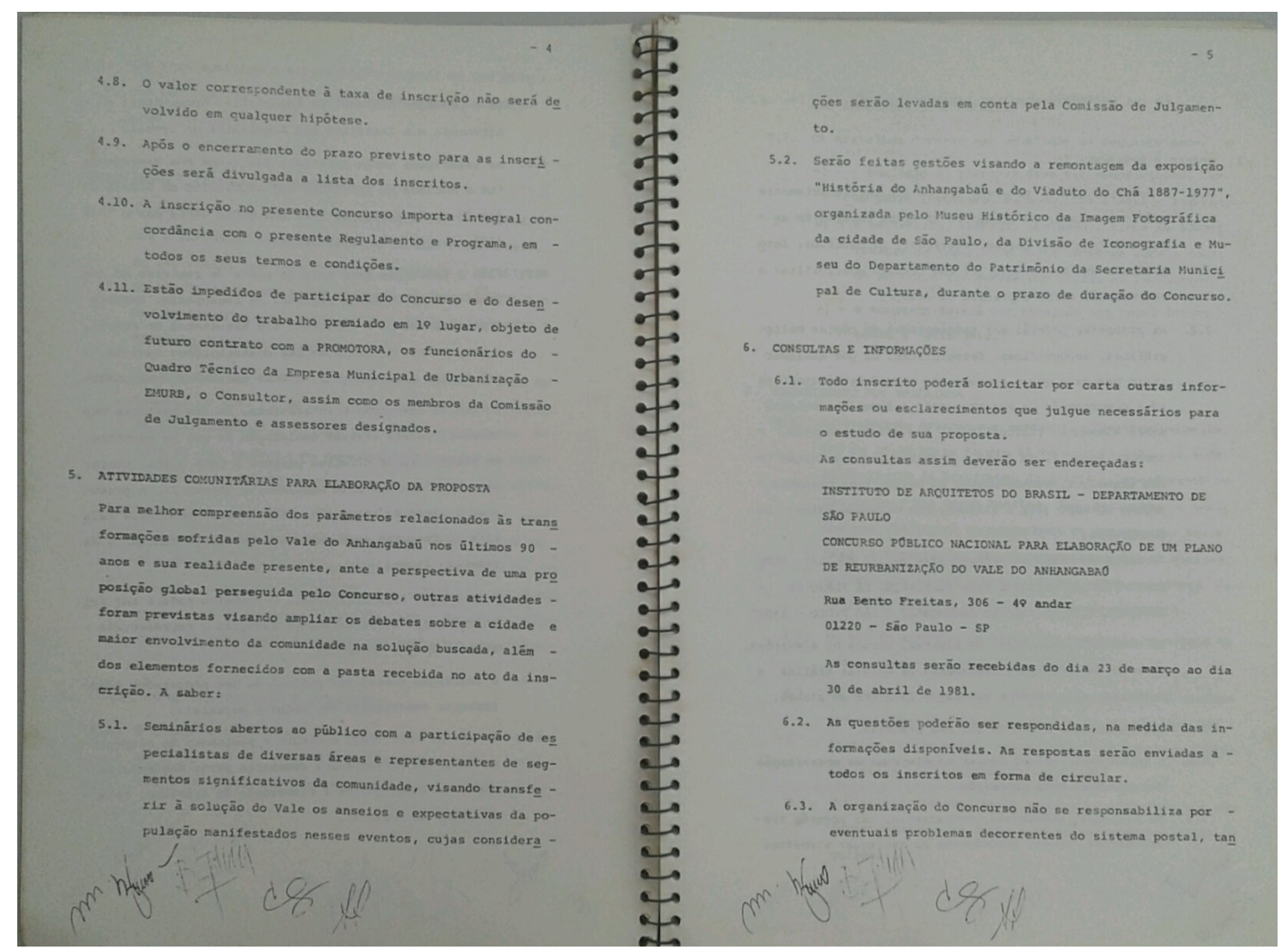

fig.30 Reprodução Edital e Programa do Concurso, acervo IAB, 1981 


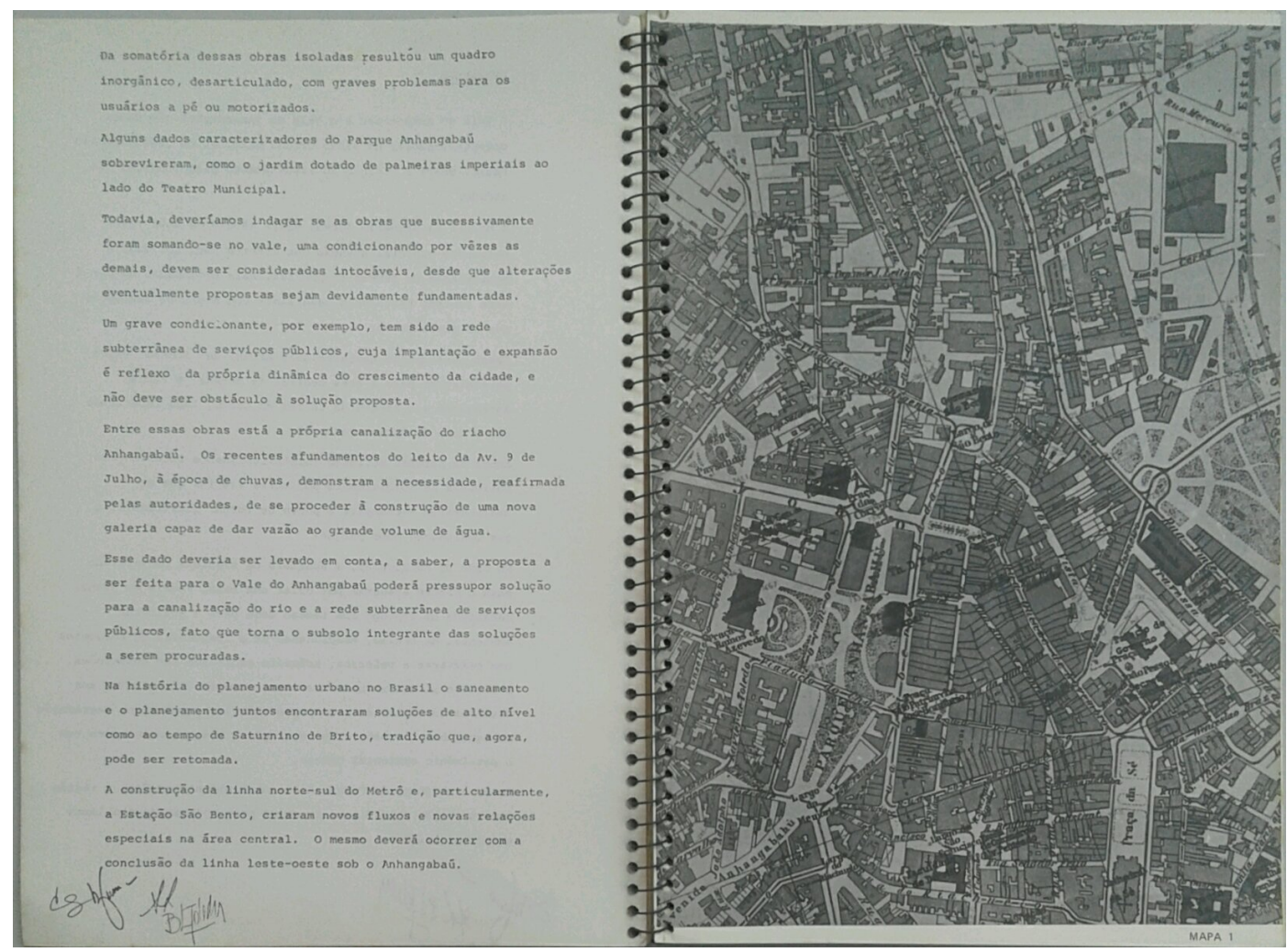

fig.31 Reprodução Edital e Programa do Concurso, acervo IAB, 1981

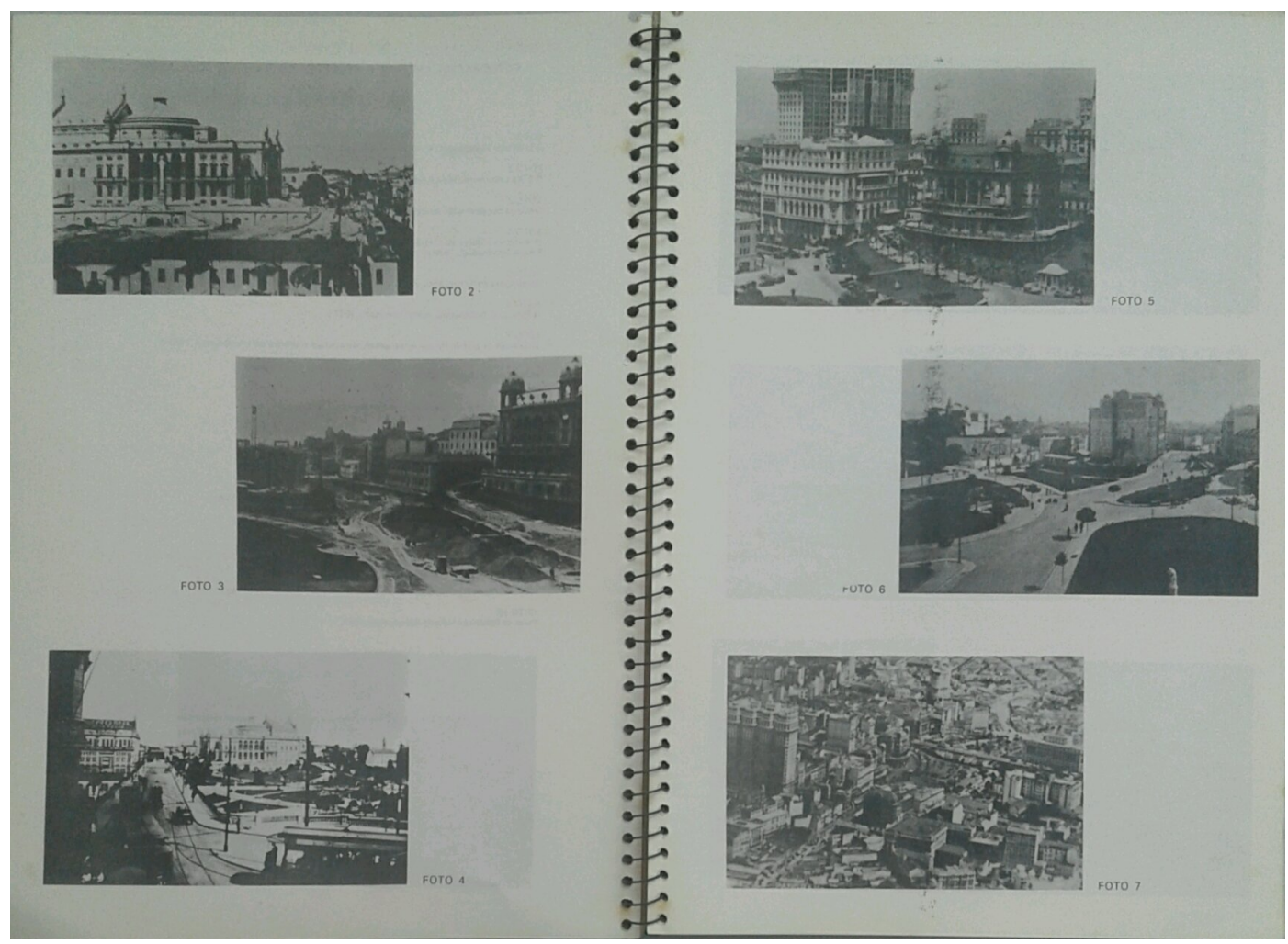

fig.32 Reprodução Edital e Programa do Concurso, acervo IAB, 1981

Reurbanização do Vale do Anhangabaú: propostas para recriação de uma paisagem 


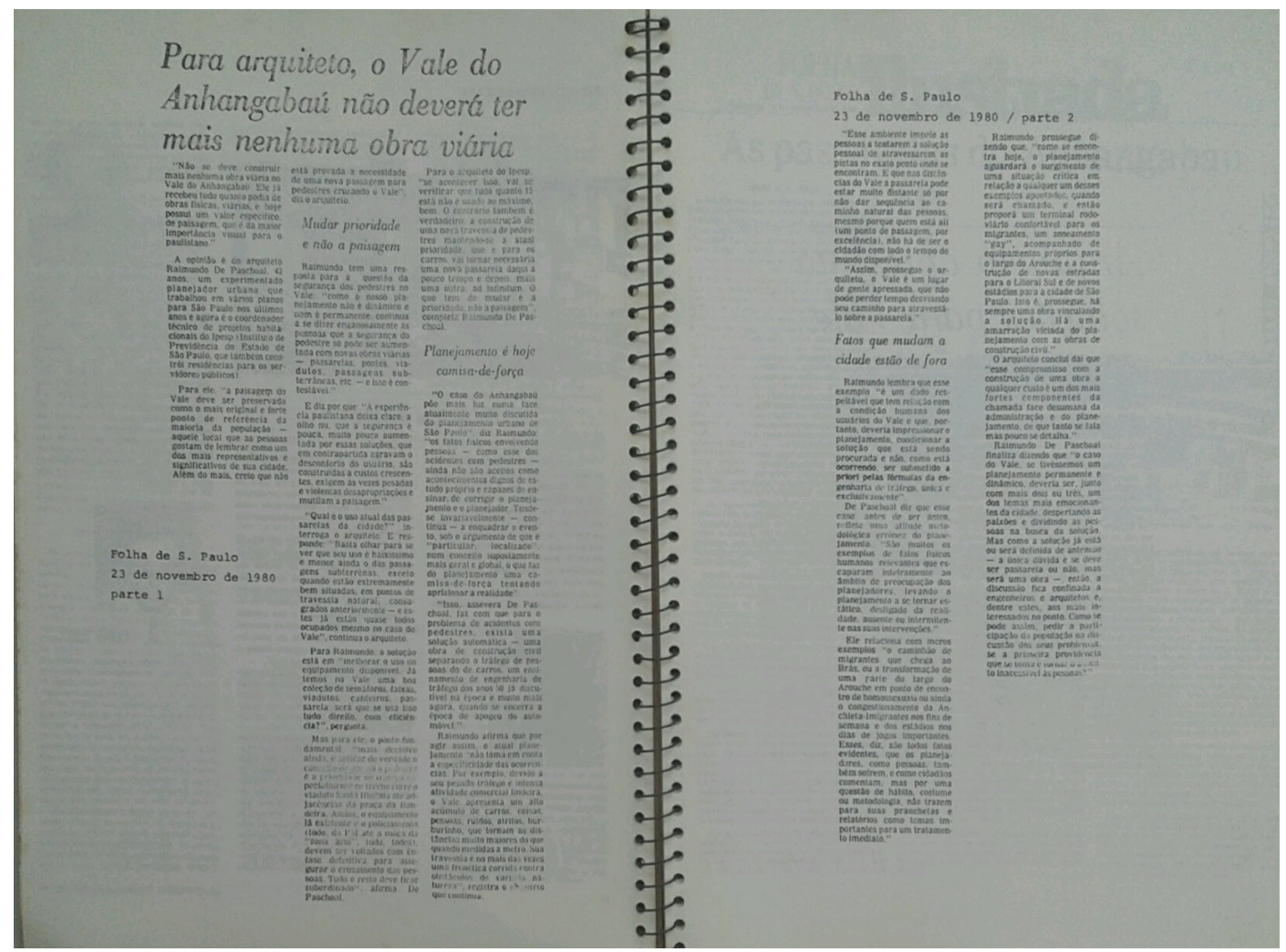

fig.33 Reprodução Edital e Programa do Concurso, acervo IAB, 1981

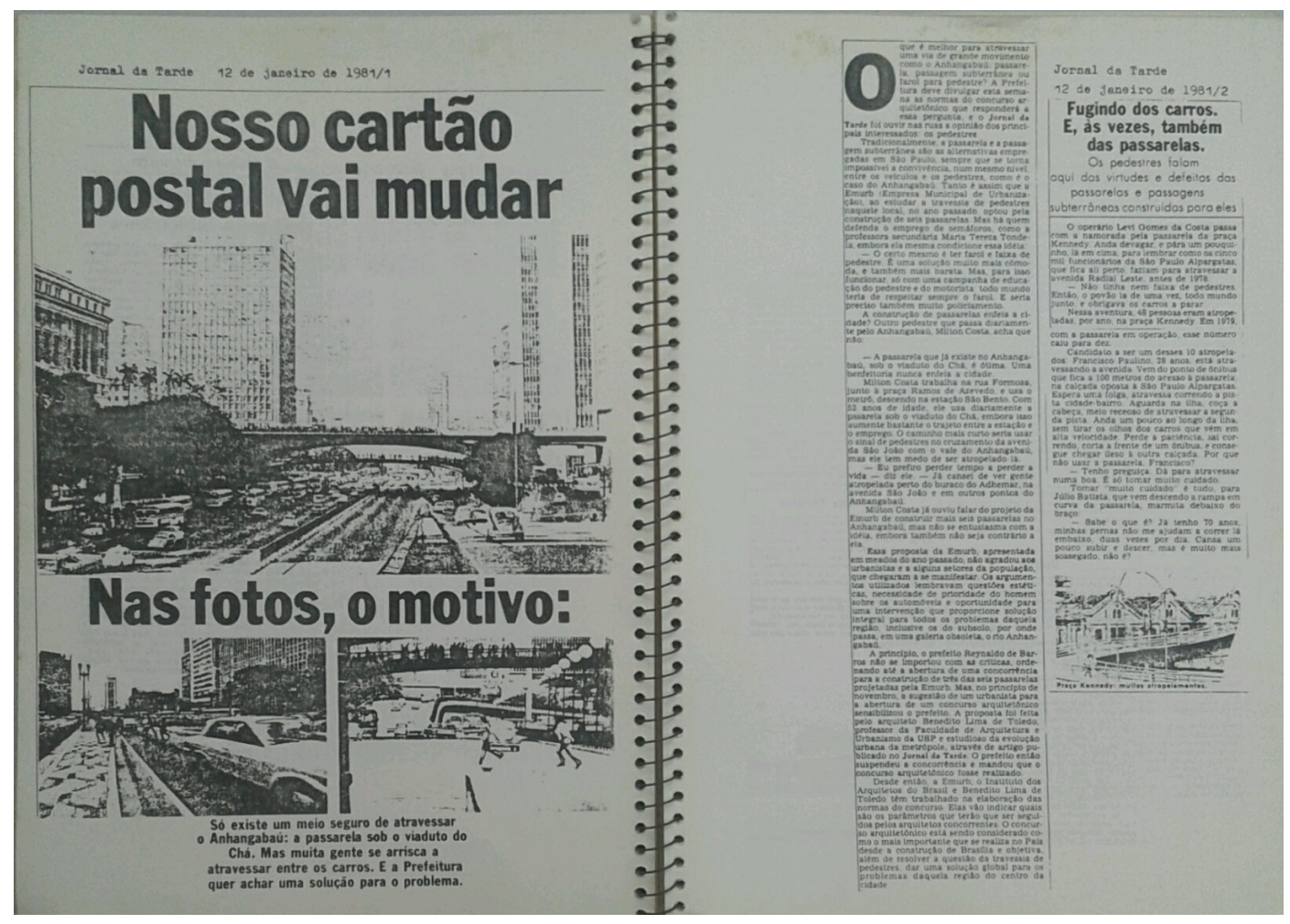

fig.34 Reprodução Edital e Programa do Concurso, acervo IAB, 1981 


\section{Seminários e Grupos de Trabalho}

Encabeçada pelo IAB-SP, a realização dos seminários abertos e dos grupos de trabalhos teve seu início em $1^{\circ}$ de abril de 1981, pouco mais de dez dias após o encerramento das inscrições para o Concurso e exatos dezessetes anos após o golpe de 1964. Inicialmente planejados para ocorrerem nos salões da Galeria Prestes Maia e Ramos de Azevedo, local em meio ao Vale e a seus usuários, as atividades tiveram de ser remanejadas de última hora para o Auditório da Escola Caetano de Campos, na Praça da República, uma vez que aqueles espaços não apresentavam condições ou já haviam se comprometido com outros eventos para mesma data. Como destaca arquiteto Paulo de Mello Bastos, membro do comitê organizador, este ciclo de palestras e debates tinha como "grande expectativa (...) abrir um caminho de mão dupla entre os técnicos dos órgãos de planejamento e a população, em contraposição aos conceitos tecnocráticos e fechados", tornando-se uma "oportunidade concreta de colocar-se em prática (...) um processo de troca de visões entre técnicos e usuários e identificação das reivindicações básicas da população para o espaço urbano" ${ }^{\prime 5}$

Do ponto de vista prático as atividades se distribuíam em quatro painéis, sendo os três primeiros destinados aos aspectos formativos/informativos e o último destinado a realização de um plenário geral, onde construir-se-ia um documento final para referencial dos projetos a serem realizados.

O primeiro painel, intitulado "Vale do Anhangabaú: Um espaço Público" tinha como enfoque a discussão do Vale como "um bem comum". Para tanto foi dado preferência para a montagem de uma mesa com representantes não-técnicos (arquitetos, engenheiros, urbanistas), sendo convidados para este evento representantes de associações comerciais, vereadores, jornalistas e sindicalistas. Com coordenação realizada pelo IAB os convidados para esta primeira mesa foram: Alberto Figueiredo e Hugo Perez , respectivamente presidente da Associação Comercial e presidente da Federação dos trabalhadores das industrias urbanas; a Comissão de obra e urbanismo da Câmara Municipal de São Paulo e a Comissão de Assuntos Metropolitanos da Assembleia Legislativa; o jornalista Julio Moreno; o presidente da do Sindicato dos empregados de estabelecimentos bancários; e José Maria Rocha Filho, membro do

5 - A Construção São Paulo, n. 1725, p. 18 
conselho coordenador das Sociedades Amigos de Bairros (SABs)

O segundo painel intitulado "Vale do Anhangabaú: Histórias e perspectivas de uso" e coordenado pelo arquiteto e professor Benedito Lima de Toledo, foram convidados o geógrafo e professor Aziz Ab' Saber; o jornalista e historiador Ernani Silva Bruno; o arquiteto e diretor da Regional Paulista do IPHAN Antonio Luiz Dias de Andrade; o pintor e professor Maurício Nogueira Lima; e o arquiteto Flavio Villaça. Como podemos ver nos esboços da mesa realizados pelo IAB ainda havia a intenção de convidar o arquiteto, professor e historiador Carlos Lemos; o pintor, professor e historiador Flavio Motta; e o pedagogo, professor e filósofo Paulo Freire, porém por motivos diversos este não puderam vir.

Já ao terceiro painel, intitulado "Órgãos intervenientes e projetos para o Vale", coube a ao arquiteto e diretor de planejamento da EMURB Paulo Julio Valentino Bruna a coordenação. Adotando-se o critério de convidar os principais órgãos atuantes na região e os profissionais que já tivessem realizado estudos para a área, foram chamados à mesa: CET (Companhia de Engenharia de Tráfego), CMTC (Companhia Municipal de Transportes Coletivos), COGEP (Coordenadoria de Gestão de Pessoas da Sacretaria de Planejamento), EMPLASA (Empresa Paulista de Planejamento Metropolitano), EMURB (Empresa Municipal de Obras e Urbanização), Metrô; e os profissionais da área de arquitetura, urbanismo e engenharia Benno Perelmutter, Eurico Prado Lopes, Figueiredo Ferraz, Gian Carlo Gasperini, João Baptista Vilanova Artigas, Jorge Wilheim, José Magalhães Junior, Pedro Cury e Samuel Szpigel.

Em complemento a estes painéis realizados sempre no período noturno, foram propostos a realização de grupos de trabalho no período matutino e vespertino. No último dia as discussões destes grupos deveriam ser debatidas conjuntamente para a confecção de um relatório final.

Os grupos imaginados à priori com composição mista tiveram, entretanto, a participação quase exclusiva de arquitetos e urbanistas. Sobre este fato, o então presidente do IAB-SP César Bergstron Lourenço comentou o seguinte: 


\title{
Seminário:
}

\section{O Vale do Anhangabaú}

\author{
01/04 Paine1: 0 Vale do Anhangabaū: 0 Espaço Püblico 20:00hs \\ 02/04 Paine1: 0 Vale do Anhangabaü: Histöria e Pers- \\ pectiva de Uso \\ $20: 00 \mathrm{hs}$ \\ $9: 00 \mathrm{hs}$ \\ $03 / 04$ Grupo de Trabalho \\ Paine1: Őrgãos Intervenientes e Projetos para \\ - Vale do Anhangabaū \\ $20: 00 \mathrm{hs}$ \\ $9: 00 \mathrm{hs}$ \\ $20: 00 \mathrm{hs}$
}

Loca1: Auditório da Escola Caetano de Campos

Praça da Repüb1ica

fig.35 Panfleto de divulgação do Seminário aberto, Acervo IAB, 1981

\begin{tabular}{|c|c|c|c|c|}
\hline 4 & Seminá & $\begin{array}{l}\text { PROGRAMA } \\
\text { rio: REUBANIZAÇAO DO V }\end{array}$ & ALE DO ANHANGABAU & \\
\hline \multicolumn{5}{|c|}{$\begin{array}{l}\text { Para atender aos objetivos a que se propõe, qual seja, o de contribuir na criação de um espaco onde setores significativas da comunidade participem das decisöes } \\
\text { sobre o uso e remanejamento do "bem comum", o Instituto de Arquitetos do Brasil. Departairento de São Paulo estará realizando um seminario de } 31 \text { de março } \\
\text { à } 03 \text { de abril de } 1981 \text {. } \\
\text { Este seminário, parte integrante de um concurso nacional de projetos para Reurbanização do Vale do Anhangabaú, compor-se-á de Painéis, Grupos de Trabatho, } \\
\text { Plenária Final e uma Exposição Pública de material sobre o Vale. }\end{array}$} \\
\hline DIAS & 31/03 - TERÇA-FEIRA & 01/04-OUARTA.FEIRA & 02/04 - OUINTA FEIRA & 03/04 SEXTA FEIRA \\
\hline $\begin{array}{l}\text { MANHA } \\
9 \text { as } 12 \text { hs. }\end{array}$ & & & & GRUPO DE TRABALHO \\
\hline $\begin{array}{l}\text { TARDE } \\
14 \text { as } 19 \text { hs. }\end{array}$ & & & & $\begin{array}{l}\text { GRUPO DE TRABALHO } \\
\text { (14 as } 16 \text { hS } \\
\text { RELATS FIO FINAL DOS } \\
\text { GRUPOS DE TRABALHO } \\
116 \text { ds } 19 \text { hs. }\end{array}$ \\
\hline $\begin{array}{l}\text { NOITE } \\
20 \text { as } 23 \text { hs. }\end{array}$ & 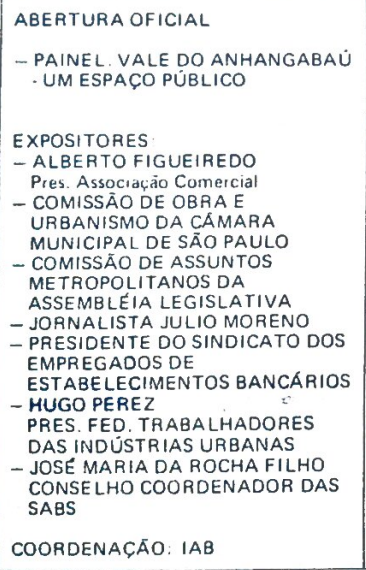 & $\begin{array}{l}\text { - PAINEL: VALE DO ANHANGABAÜ } \\
\text { - HISTORIA E PERSPECTIVAS DE } \\
\text { USO. } \\
\text { EXPOSITORES } \\
\text { - AZIZAB'SABER } \\
\text { - ERNANI DA SLLVA BRUNO } \\
\text { - ANTONIO LUISDIAS DE ANDRADE } \\
\text { - MAURICIO NOGUEIRA LIMA } \\
\text { - FLAVIO VILLACYA } \\
\qquad . \\
\text { COORDENACCAOO: BENEDITO LIMA } \\
\text { DE TOLEDO }\end{array}$ & $\begin{array}{l}\text { - PAINEL ORGAOOS INTERVENIEN. } \\
\text { TESE PROJETOS PARA O VALE. } \\
\text { EXPOSITORES: } \\
\text { - CET } \\
\text { - CMTC } \\
\text { - COGEP } \\
\text { - EMPLASA } \\
\text { - EMURB } \\
\text { - METRO } \\
\text { - BENNO PERELMUTTER } \\
\text { - EURICO PRADO LOPES } \\
\text { - FIGUEIREDO FERRAZ } \\
\text { - GIAN CARLO GASPERINI } \\
\text { - J. B. VILANOVA ARTIGAS } \\
\text { - JORGE WILHEIM } \\
\text { - JOSE MAGALHĀES JR. } \\
\text { - PEDRO CURY } \\
\text { - SAMUEL SZPIGEL } \\
\end{array}$ & $\begin{array}{l}\text { - PLENARIA FINAL } \\
\text { DISCUSSÃO SOBRE O DOCUMENTO } \\
\text { FINAL DOS GRUPOS DE TRABALHO }\end{array}$ \\
\hline
\end{tabular}

fig.36 Programação do Seminário aberto, Acervo IAB, 1981

Reurbanização do Vale do Anhangabaú: propostas para recriação de uma paisagem 
"O seminário contou com mecanismos imperfeitos, experimentais, mas nem por isso deixou de ter uma importância fundamental na discussão dos problemas da cidade. A criação do Concurso é um passo assegurado para a discussão dos problemas mais cruciais dos espaços urbanos, que precisam ser discutidos pelos mais diversos setores da população. Essa participação pode e deve ser reforçada"

Fato é que, apesar do intuito de realizar nos grupos de trabalho discussões acerca dos problemas urbanísticos do Vale para então fundamentar orientações para os projetos do Concurso, os grupos de trabalho acabaram por se enveredar na discussão sobre o próprio processo do Concurso e sobre as mais diferentes questões políticas. Abaixo transcrevemos os tópicos-temas levados por cada grupo para a discussão final:

\section{Grupo 1}

- Enquanto arquitetos não queremos atuar e contribuir com nosso conhecimento técnico para a cidade só em concursos. Isso é um desperdício do potencial de conhecimento técnico da categoria - trabalho gratuito. Queremos trabalho efetivo.

- Enquanto cidadão a cidade não pode se dar ao luxo desse desperdício, seja de 800 profissionais trabalhando numa área só, quando todo o restante aguarda, seja o desperdício de dinheiro público aplicado em projetos que são engavetados pelas alterações de um poder inquestionável, imposto e que não dá a menor satisfação.

Grupo 2

- Que a participação da população nas questões urbanas é fundamental.

- Que cada decisão a ser tomada deverá ter a consulta a população, uma vez ser ela ser fruto do seu trabalho.

- Fortalecimento do legislativo. Fortalecimento de todas as formas de representação comunitária.

- Criação de novos canais de consulta e controle.

Que o julgamento das soluções propostas não fique restrito aos setores tecnocratas de visão estreita, nem à vontade de um governante biônico, sem eleição.

- Conquista da democracia na prática, discutindo as questões que nos são afetas

6 - A Construção São Paulo, n. 1731, p. 22 


\section{Grupo 3}

- Que a cidade existe e é gerida com o dinheiro do povo. Portanto ele deve votar e definir as prioridades a distribuição de recursos etc.

- Orçamento público deverá voltar a ser discutido no legislativo

Grupo 4

- Ainda se a cidade é gerida com o dinheiro público, as soluções para a mesma não devem ter como ponto central o lucro, a rentabilidade de casa intervenção.

- Os recursos existem, são do povo e para ele devem reverter, para a melhoria e estabelecimento da qualidade de vida.

- O povo como usuário e não como cliente, como tem sido.

- Que o julgamento dos trabalhos seja realizado em duas instancias: a primeira realizada pelo júri indicado e com caráter de pré-seleção de onde seriam retirados 30 trabalhos para exposição e “julgamento" popular. Deste julgamento, dentre os projetos mais votados, seria escolhido novamente pelo júri do concurso o vencedor.

\section{Grupo 5}

- Que se caminhe em direção ao urbanismo, aos projetos urbanísticos que reflitam os anseios populares. Que o planejamento programe e viabilize tais projetos. Que as intervenções técnicas sejam feitas de acordo com esse encadeamento.

- O que se vê é o justo contrário: obras setorizadas, isoladas, umas conflitando com outras. Obras saindo em função de pressões de setores privados com vistas a lucros imediatos, levando o planejamento a um trabalho insano de coordenar as coisas mais esdrúxulas e o urbanismo o plano geral da cidade inexistente 


\section{Comissão Julgadora e Resultado}

Como exposto anteriormente, a comissão julgadora foi escolhida pela EMURB e era composta por cinco membros, sendo que destes três deveriam pertencer ao quadro de juris do IAB e pelo menos dois pertencentes ao departamento de São Paulo.

Para tanto foram destacados os arquitetos Eduardo Corona (presidente da comissão), Edgar Albuquerque Graeff e Fernando Chacel, graduados respectivamente em 1946, 1947 e 1953 pela Faculdade Nacional de Arquitetura da Universidade do Brasil; Carlos Maximiliano Fayet, graduado em 1953 pela Escola de Artes da Universidade Federal do Rio Grande do Sul; e Jon Andoni Maitrejean, graduado em 1953 pela Faculdade de Arquitetura e Urbanismo da Universidade de São Paulo.

Conforme descrito na ata de julgamento, a análise dos trabalhos entregues se deu em etapas, sendo que na primeira delas, baseando-se nos objetivos estabelecidos pelo Edital, pelo Termo de Referência e demais documentos oferecidos, a Comissão escolheu conjuntamente e por unanimidade trinta e quatros propostas, permanecendo as demais disponíveis para, a qualquer momento, serem novamente avaliadas. Neste ponto, Eduardo Corona em entrevista concedida em junho de 1981 à revista $\mathrm{A}$ Construção São Paulo ${ }^{7}$ destaca:

“(...)apenas 40\% dos trabalhos apresentavam um nível bom. A maioria das propostas não eram boas, de autoria de profissionais recém-formados ou com pouca experiência. Mesmo algumas boas ideias foram tecnicamente mal elaboradas, entregues de qualquer jeito, provavelmente pela inexperiência dos autores".

Dando continuidade ao julgamento, os trinta e quatro trabalhos pré-selecionados foram submetidos à análise individual de cada membro da Comissão para então serem novamente apreciados de forma coletiva. Desta segunda rodada de análise foram destacados dezessete trabalhos. Nesta etapa da análise, conforme descreve Corona na mesma entrevista:

7 A Construção São Paulo, Número 1741, p. 10 
"as trinta e quatro propostas foram divididas em três famílias de solução, que apresentavam as características: soluções subterrâneas, soluções aéreas e outras soluções. Dentro destas três famílias foram destacadas aquelas que resistiram à analise devido à sua criatividade, coerência e boa qualidade".

Chegando ao terceiro e último dia de análise, a partir dos estudos individuais prévios e da análise individual e coletiva das propostas analisadas, os membros da Comissão estabeleceram por consenso as condições básicas que deveriam atender os projetos a serem destacados com menções e prêmios. Conforme listado na Ata de Julgamento estas condições seriam:

- A recuperação das Praças da Bandeira e do Correio e a revalorização e integração da Praça Ramos de Azevedo, fundamentais à existência do Parque como um todo

- Devolução da área do Vale para o uso da população

- Adequação da solução proposta ao contexto da área central e às estruturas de atividades, da malha viária e dos transportes coletivos previstos para a cidade

- Previsão e destinação dos espaços públicos e equipamentos para uso local e metropolitano

- A eficácia da proposta no que se refere ao volume e natureza das intervenções sugeridas e o resultado obtido

- Respeito aos valores históricos, culturais e ambientais do Vale do Anhangabaú

- Avaliação das interferências decorrentes das etapas de implantação propostas

Por fim, partindo destas condições básicas para a análise dos dezessete trabalhos restantes, a Comissão Julgadora, chegou a seguinte decisão de forma unanime:

- $1^{\circ}$ Lugar - Proposta 17

- $2^{\circ}$ Lugar - Proposta 82

- $3^{\circ}$ Lugar - Proposta 16

- Menção Honrosa - Proposta 15

- Menção Honrosa - Proposta 34

- Menção Honrosa - Proposta 83

- Menção Honrosa - Proposta 14

- Menção Honrosa - Proposta 20 

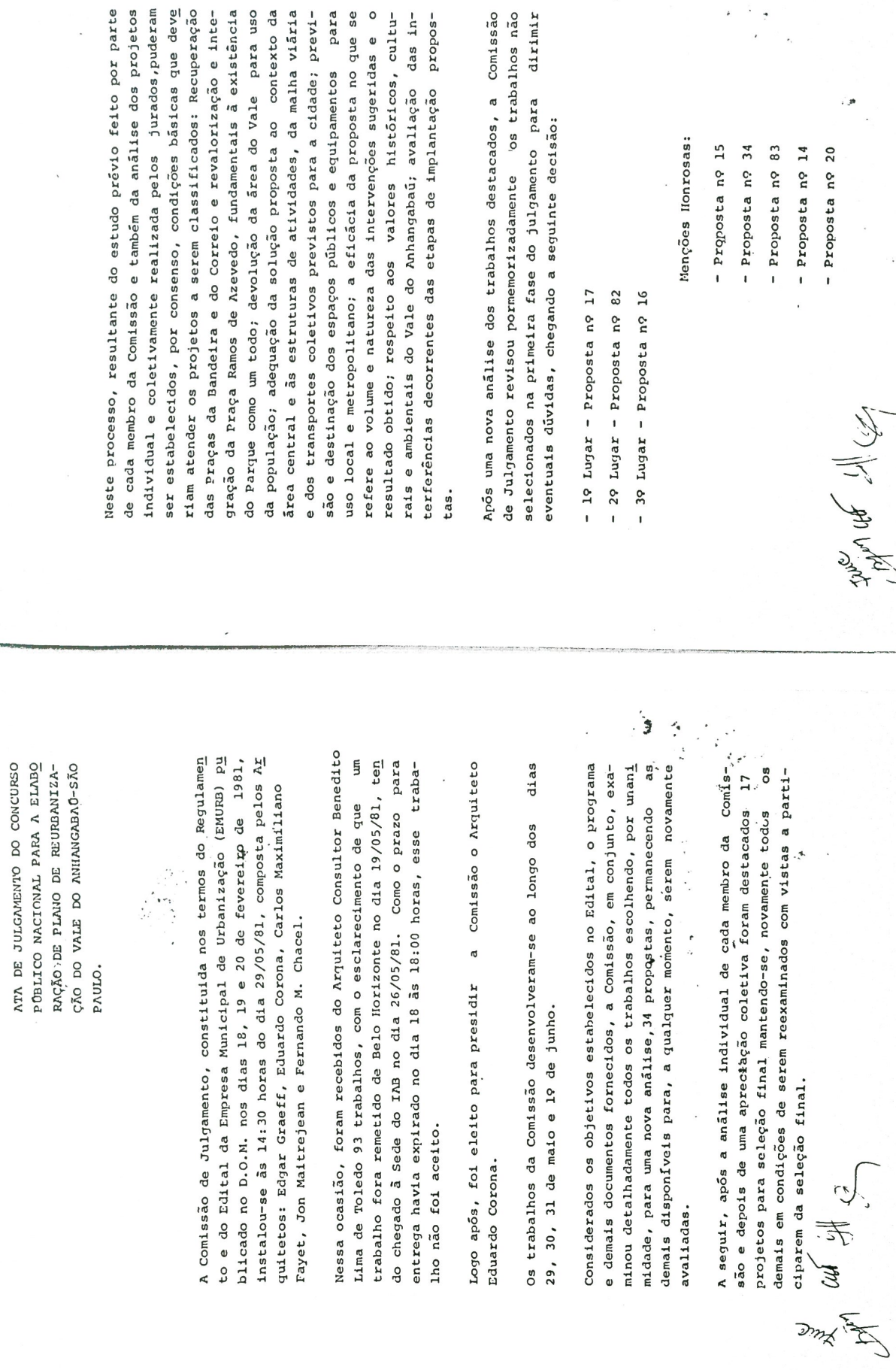

fig.37 Ata do Juri, acervo do IAB, 1981 
Reurbanização do Vale do Anhangabaú: propostas para recriação de uma paisagem 


\section{As Propostas}

Conforme visto na seção anterior, dentre os 93 trabalhos entregues, a comissão julgadora distribuiu ao final do Concurso oito prêmios, sendo cinco menções honrosas e um terceiro, um segundo e um primeiro prêmio. A estas equipes foram pagas premiações em dinheiro, sendo destinados Cr\$200.000,00 (duzentos mil cruzeiros) para cada uma das cinco menções, Cr\$400.000,00 (quatrocentos mil cruzeiros) para a equipe terceira, $\mathrm{Cr} \$ 600.000,00$ (seiscentos mil cruzeiros) para a segunda e Cr\$1.000.000,00 (um milhão de cruzeiros) para a primeira colocada ${ }^{8}$. À equipe vencedora garantia-se ainda o direito de firmar contrato junto à Prefeitura para a execução do Plano Diretor do Vale do Anhangabaú, o qual seria definido do ponto de vista do escopo e dos valores posteriormente. Quanto à contratação para o Projeto Executivo não havia dentro do Edital garantias formais, apenas a menção de que este ocorreria "oportunamente"

Mas, apesar dos valores das premiações e a garantia de contratação para o Plano Diretor estarem assegurados pelo Edital, segundo a reportagem do Jornal O Estado de São Paulo de 26/06/1981, aos participantes premiados foram pagas quantias aproximadamente $37 \%$ menor do que as anunciadas pelo Concurso. Tal diferença devia-se sobretudo aos descontos daqueles valores referentes ao Imposto de renda e do ISS. Quanto à diminuição de seu prêmio, Jorge Wilheim chamou a atenção de que o valor final recebido por ele era aproximadamente $10 \%$ inferior ao valor investido por seu escritório em todo o processo, o que dizer dos demais concorrentes?

8 - Atualizando estes números com base no IPCA, em dezembro de 2016, teríamos: R\$17.011,46; $\mathrm{R} \$ 34.022,92 ; \mathrm{R} \$ 51.034,38$ e $\mathrm{R} \$ 85.957,30$. 

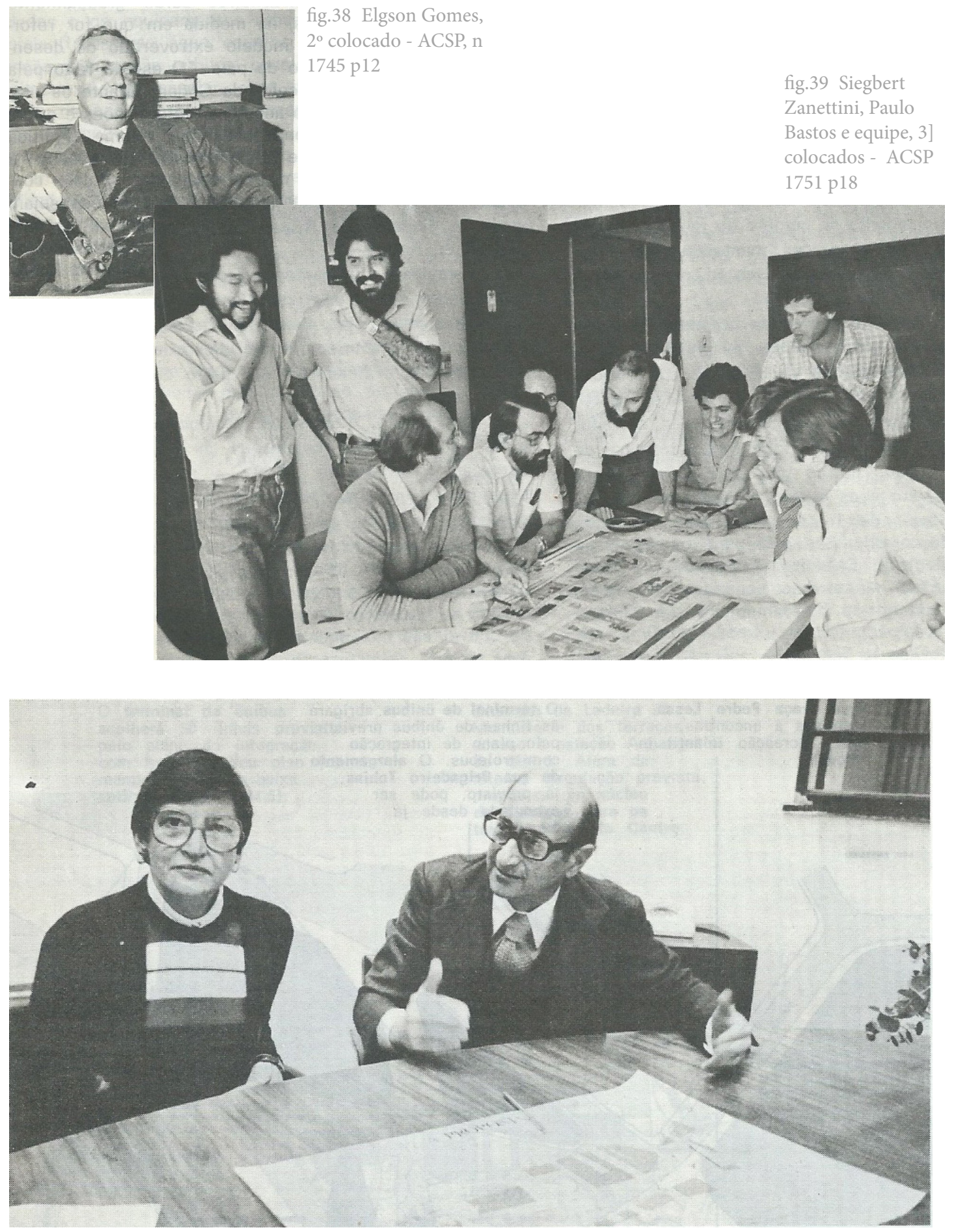

fig.40 Rosa Kliass

e Jorge Wilheim, $1^{\circ}$

colocados, ACSP

1741 p06 
Para além do destacamento e premiação destas oito equipes, o Edital também previa a realização de uma exposição pública com todos os trabalhos entregues, a qual inicialmente se realizaria na Galeria Prestes Maia, mas depois, devido à incompatibilidade de datas, foi transferida às pressas para o MASP. Sobre esta exposição, fora algumas notícias e anúncios veiculados na imprensa da época, não encontramos nenhum material. Questionados sobre o paradeiro do material exposto (originais e fotocópias) nem o MASP nem a EMURB souberam informar. Dada à esta impossibilidade de resgatar alguns dos materiais das propostas premiadas realizaremos a seguir a apresentação de apenas seis das oito propostas. 


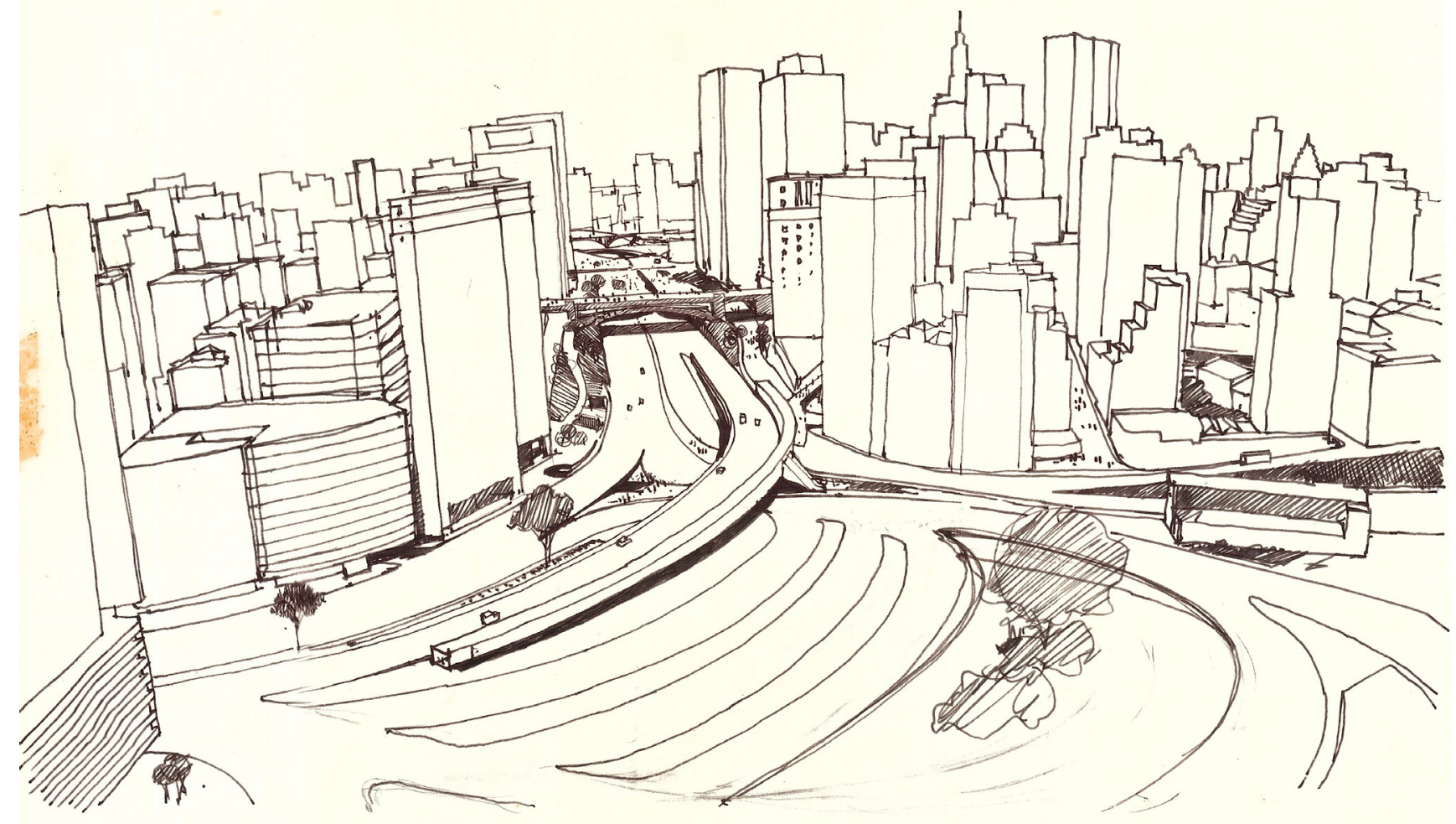

fig.41 Perspectiva do

Vale do Anhnagabaú,

acervo Aflalo / Gaspe-

rini Arquitetos 


\section{Projeto 34 [menção honrosa]}

Autores:

Plínio Croce - Arquiteto (São Paulo-SP)

Robertos Claudio dos Santos Aflalo - Arquiteto

(São Paulo-SP)

Gian Carlo Gasperini - Arquiteto (São Paulo-SP)
Colaboradores:

Carlos Fernando do Amaral Guimarães - Arquiteto

Léa Vaidergorin Rzezak - Arquiteta

Robertos Claudio dos Santos Aflalo Filho -

Arquiteto

Luis Felipe Aflalo Herman - Arquiteto

Marcelo Aflalo - Arquiteto

Alcides B. Borcaro Filho - Arquiteto

A proposta apresentada pelos arquitetos Croce, Afalo e Gasperini, graduados respectivamente pelas Faculdade de Engenharia Mackenzie (1946), Faculdade de Arquitetura e Urbanismo Mackenzie (1950), e Faculdade Nacional de Arquitetura do Rio de Janeiro (1949) apresenta como estratégia básica para resolução do conflito entre pedestres e veículos a mesma estratégia de Túnel-Plataforma utilizada por outras equipes. Para tanto os autores propõem o rebaixamento da via expressa do Vale do Anhangabaú em seu sentido longitudinal em um trecho de 560 metros e 6,5 metros de profundidade, permitindo assim o fluxo ininterrupto de veículos (tanto individuais como coletivos) na cota mais baixa e a criação de uma grande superfície destinada ao uso exclusivo por pedestres na cota superior. Na proposta de CA\&G as pistas apresentam quatro faixas de rolagem no sentido Norte-Sul e cinco no sentido Sul-Norte, sendo que em cada um dos sentidos a faixa mais à direita é de uso exclusivo para os trólebus.

Em complemento à criação desta passagem subterrânea para automóveis, CA\&G defendem a realização de algumas outras obras viárias a fim de "consolidar a voca- 
ção do Vale como artéria expressa de trânsito de passagem pelo centro da cidade" Iniciando pela porção Sul do Vale, junto à confluência entre Avenidas Vinte e Três de Maio e Nove de Julho a proposta defendo um ligeiro remanejamento do traçado viário a fim de alargar o canteiro central entre a Avenida Vinte e Três de Maio e o estacionamento de ônibus (atual terminal bandeira). Com isso seria possível a implantação da saída da passagem subterrânea para pedestres e do acesso à passarela que seria construída junto ao viaduto Eusébio Stevaux, bloqueando assim totalmente a travessia de pedestres em meio ao leito carroçável. Por esta passarela proposta seria possível acessar às Ruas Doutor Falcão e Ladeira São Francisco por meio de rampas e escada rolantes. Este remanejamento permitiria ainda o acesso do Viaduto Jacareí à Avenida Nove de Julho pela Rua Santo Amaro e a saída do tráfego do Anhangabaú-Rótula através da Rua Asdrúbal do Nascimento.

Já na porção Norte, entre a Avenida São João e o Viaduto Santa Efigênia, CA\&G propõem a criação de um novo viaduto de 230 metros de extensão que permitiria a conversão à esquerda em direção à Avenida São João. Este novo viaduto partiria das pistas sentido Sul-Norte da passagem subterrânea, cruzaria sobre as pistas de sentido oposto, e se encaixaria no vazio existente no arvoredo da Praça Pedro Lessa.

Corte Longitudinal + planta destacando intervenções

Do ponto de vista do desenho dos espaços livres chama atenção a proposição da grande plataforma de uso exclusivo por pedestres, a qual os autores se referenciam com "placa”. Em sua superfície CA\&G propõem a criação de uma sinuosa fenda a qual os autores creditavam três aspectos: o primeiro seria favorecer a ventilação natural das plataformas de embarque e desembarque de trólebus posicionadas ao longo dos túneis e do próprio sistema viário; o segundo seria permitir o vislumbre da paisagem do Vale pelos motoristas que o atravessassem no seu sentido Norte-Sul-Norte; o terceiro, por fim, seria restituir o traçado do antigo Córrego do Anhangabaú ao Vale que emprestou seu nome ${ }^{10}$.

Ainda quanto ao desenho dos espaços livres podemos ressaltar o desejo da equipe de "recriar o conceito do antigo parque do Anhangabaú como um espaço de trânsito e parada de pedestres, com áreas ajardinadas e equipadas para atividades sociocultu9 - A Construção São Paulo, número 1755 10 - A construção São Paulo, número 1755 


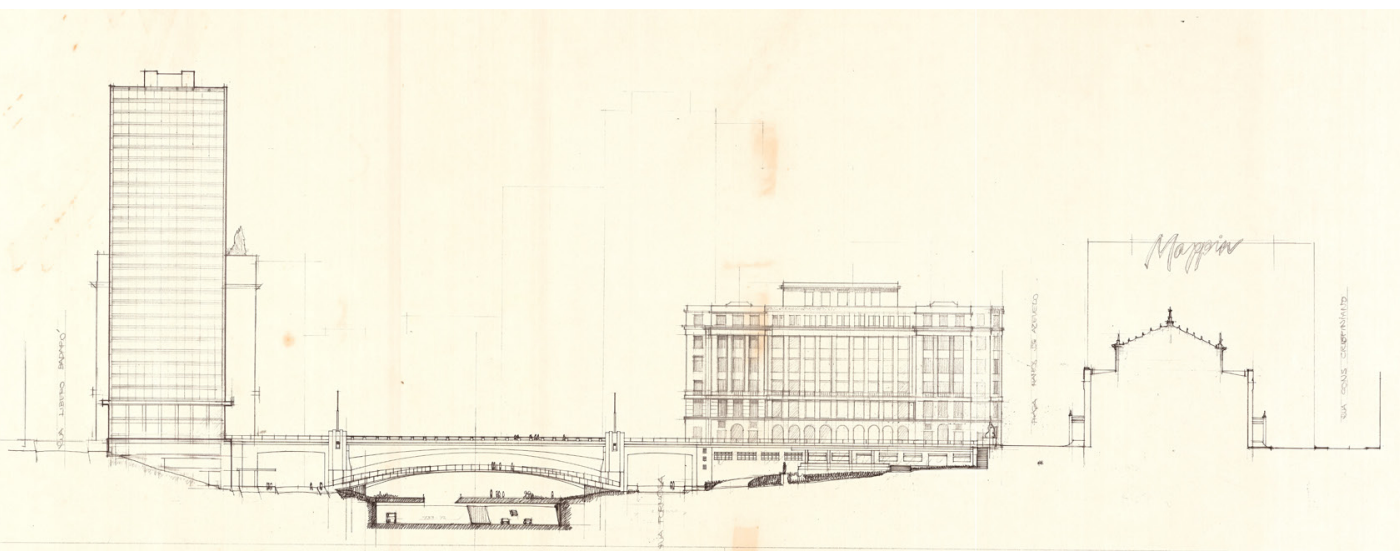

fig.42 Corte transversal pelo Vale do Anhnagabaú, acervo Aflalo / Gasperini Arquitetos

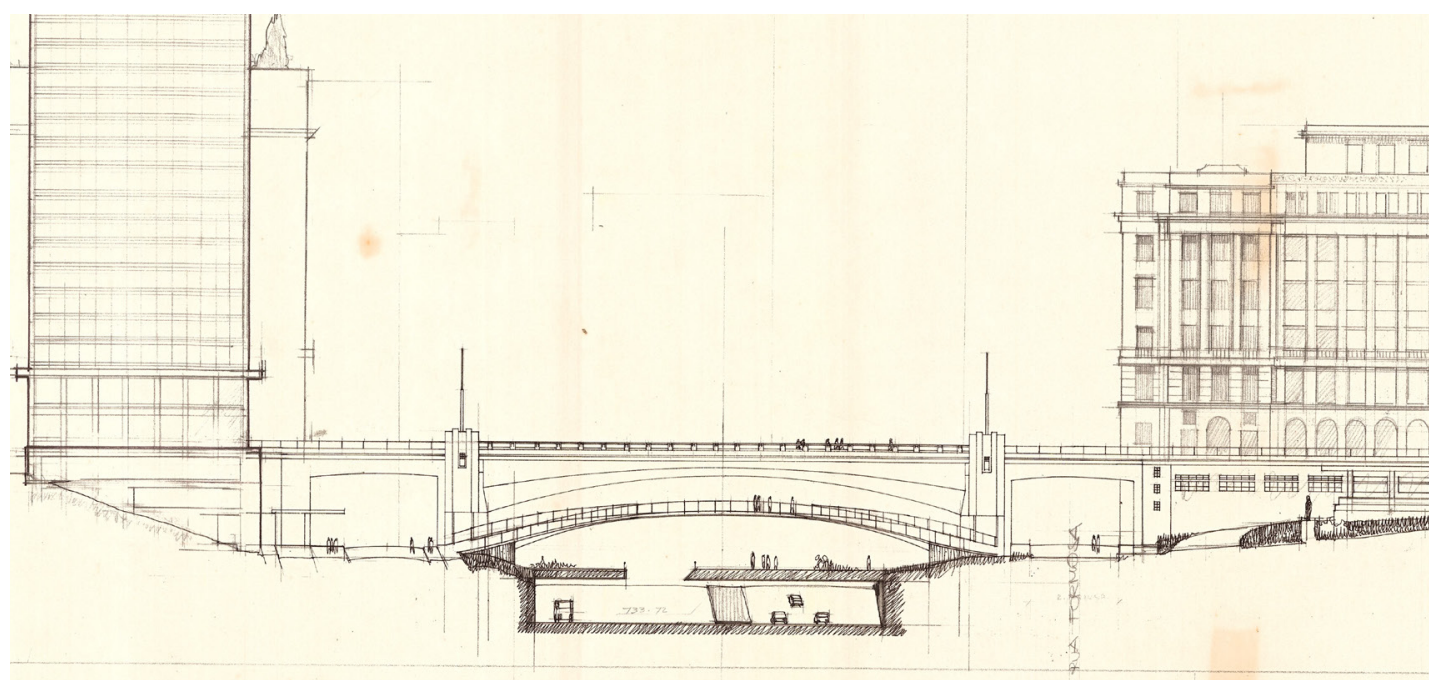

fig.43 Detalhe do corte transversal pelo Vale do Anhnagabaú, acervo Aflalo / Gasperini Arquitetos

rais e de lazer"11. Para tanto a equipe propôs grandes áreas ajardinadas e a criação de caminhos que facilitassem a travessia dos transeuntes no sentido Leste-Oeste-Leste. Complementado estes passeios criados em meio a "placa" e proposta ainda sugerem a criação de duas novas zonas de circulação exclusiva de pedestres nas laterais do Vale: um novo calçadão entre o Teatro Municipal e a Praça Ramos de Azevedo e a extensão do Largo de São Bento para as laterais do Convento.

Em complemento a este desenho os arquitetos propõem a criação de uma série de novos programas em meio a plataforma ou em suas bordas a fim de dar suporte e incentivar o uso deste espaço. Na porção central do Vale os arquitetos propõem o

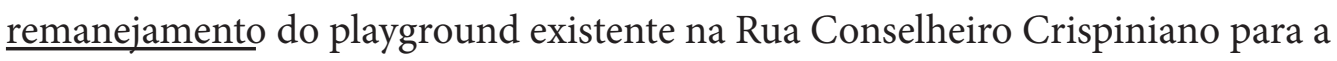
11 - Ibidem 
plataforma que em conjunto com o edifício do conservatório conformaria um novo equipamento sociocultural. Ainda neste trecho $C A \& G$ propõem a abertura dos baixios do Viaduto do Chá e áreas anexas ao Teatro Municipal para o jardim da Praça Ramos de Azevedo, visando assim a revitalização deste espaço.

Na porção Sul, a equipe sugere a revitalização da região entre a Câmara Municipal e a Praça da Bandeira a partir da criação de um novo centro comercial que promoveria a ligação coberta e equipada entre o Vale e a zona alta junto ao Viaduto Jacareí.

Por fim, de forma distribuída, CA\&G propõem a criação de três novos edifícios-garagens em terrenos vazios nas proximidades do Vale. O primeiro destes três edifícios-garagem seria implantado no miolo de quadra do Edifício Touring, defronte à Ladeira da Memória. O segundo seria implantado no miolo de quadra do Edifício da CSI, acessado pela Avenida São João. O terceiro, próximo à estação São Bento do Metrô, seria implantado junto à Avenida Anhangabaú sentido Sul-Norte.

Quanto ao disciplinamento, uso e regulação do solo, a proposta liderada por CA\&G prevê a desapropriação e demolição dos imóveis voltados para a Avenida Anhangabaú localizados entre a Avenida São João e a Estação São Bento a fim de permitir a implantação das obras viárias, das plataformas subterrâneas de trólebus e a construção de área para serviços públicos.

A fim de promover o incentivo a renovação urbana $C A \& G$ propõem ainda a criação de uma nova Zona Especial para a área correlacionada ao Vale, que a semelhança da Z8-200 ${ }^{12}$, sujeitaria toda nova edificação, reforma ou remanejamento à autorização da COGEP, com a diferença que neste caso seriam estabelecidos vínculos urbanísticos tais que incentivassem a renovação urbana através da iniciativa privada.

Por fim, no que tange à valorização do patrimônio histórico e ambiental do Vale, com exceção à extensão do largo de São Bento e a implantação de um calçadão no entorno do Teatro Municipal, a equipe liderada por $C A \& G$ não faz nenhuma menção.

12 - Z8-200 é como era conhecida a zona designada para bens tombados pelo IPHAN/CONDEPHAT. Segundo os critérios desta Zona toda e qualquer intervenção deveria ser previamente validada e autorizada pela COGEP. 


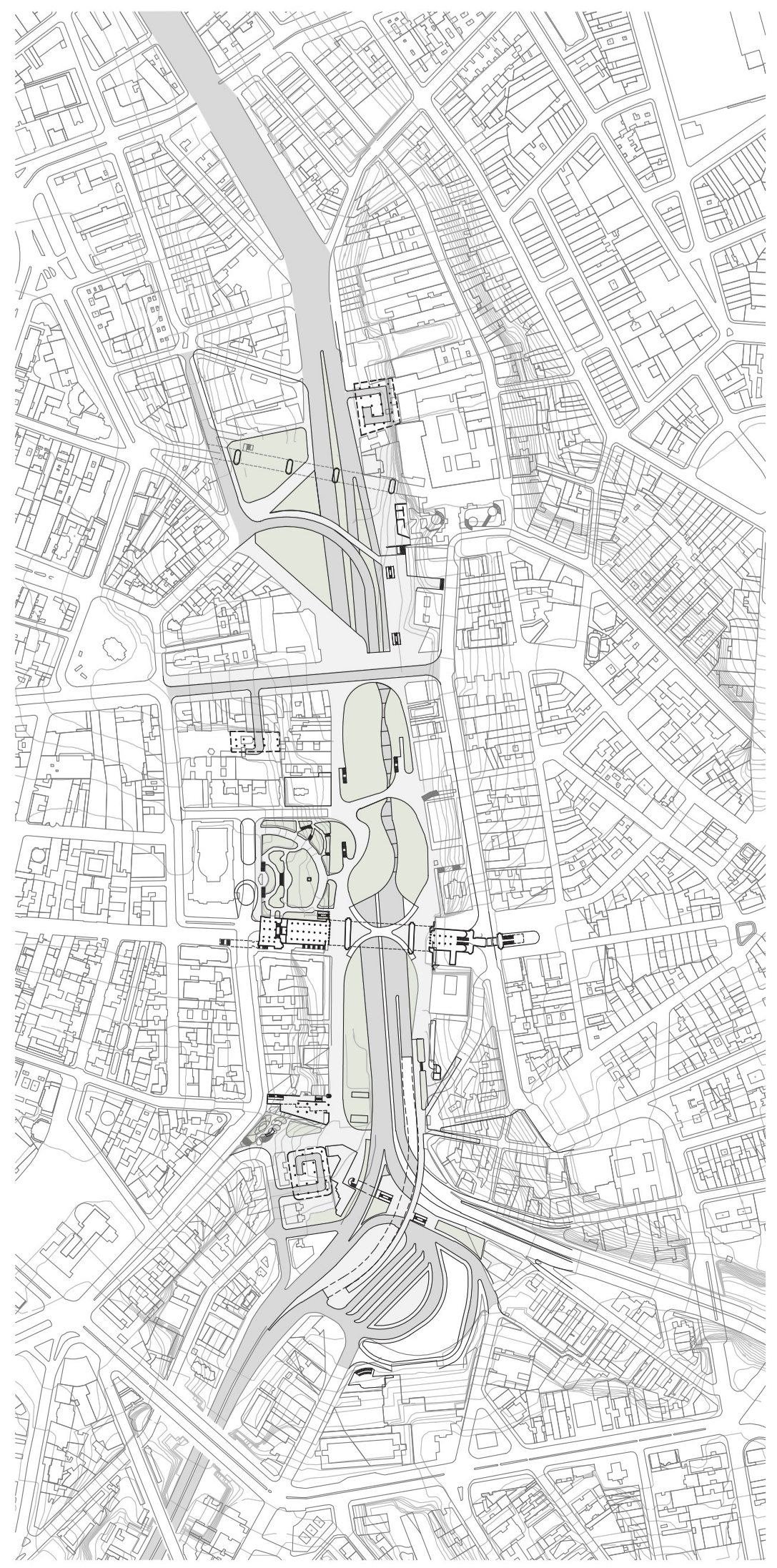

fig.44 Redesenho da propota de

Croce, Aflalo e

Gasperini. Acervo do Autor
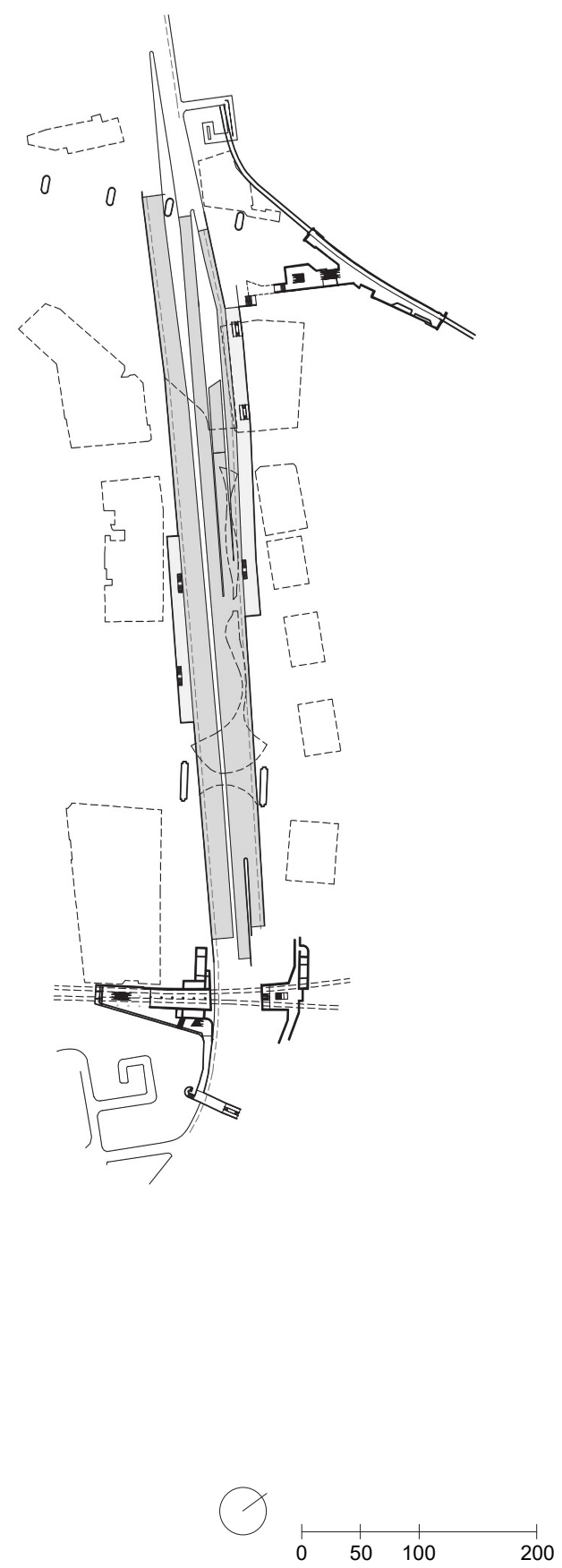


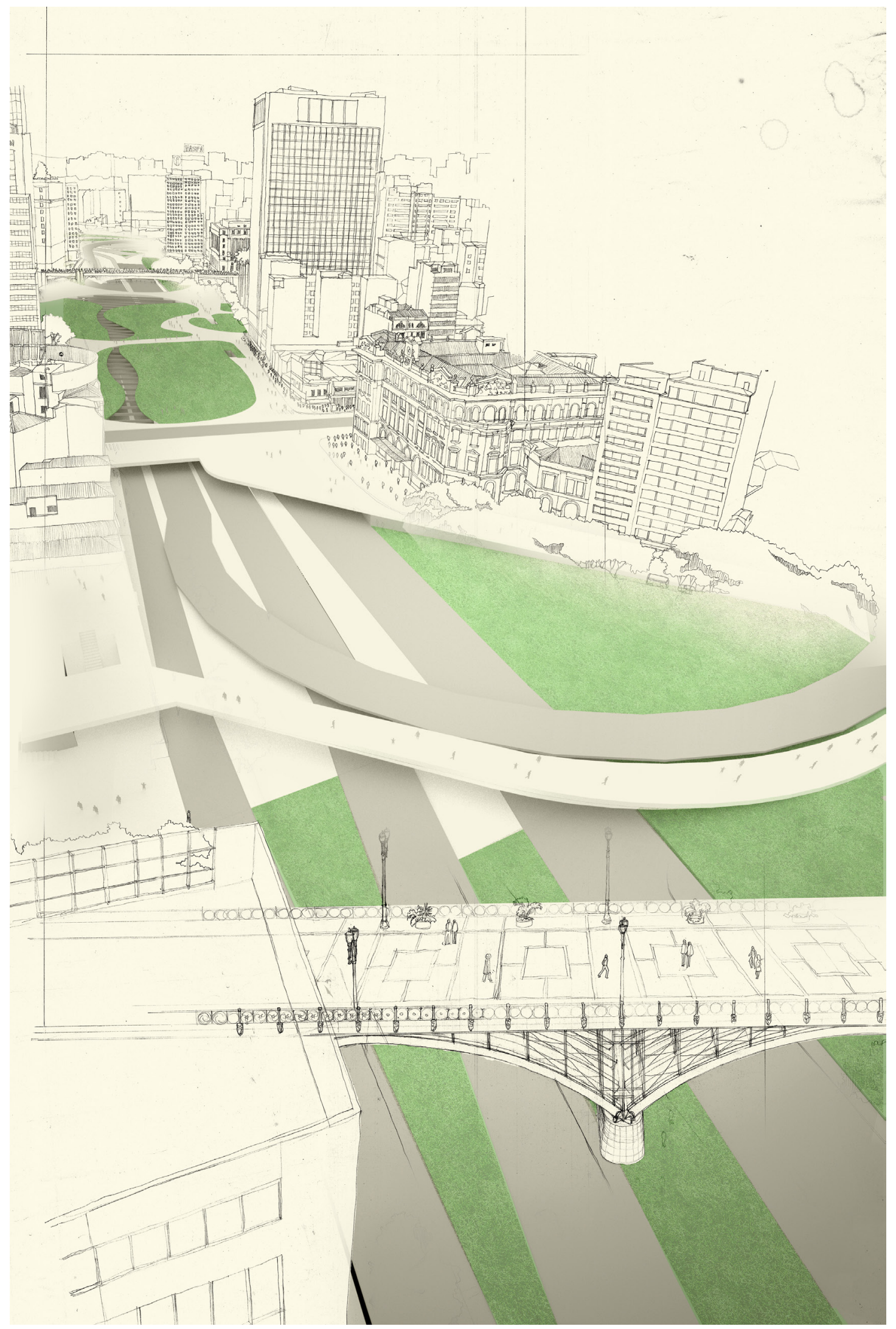




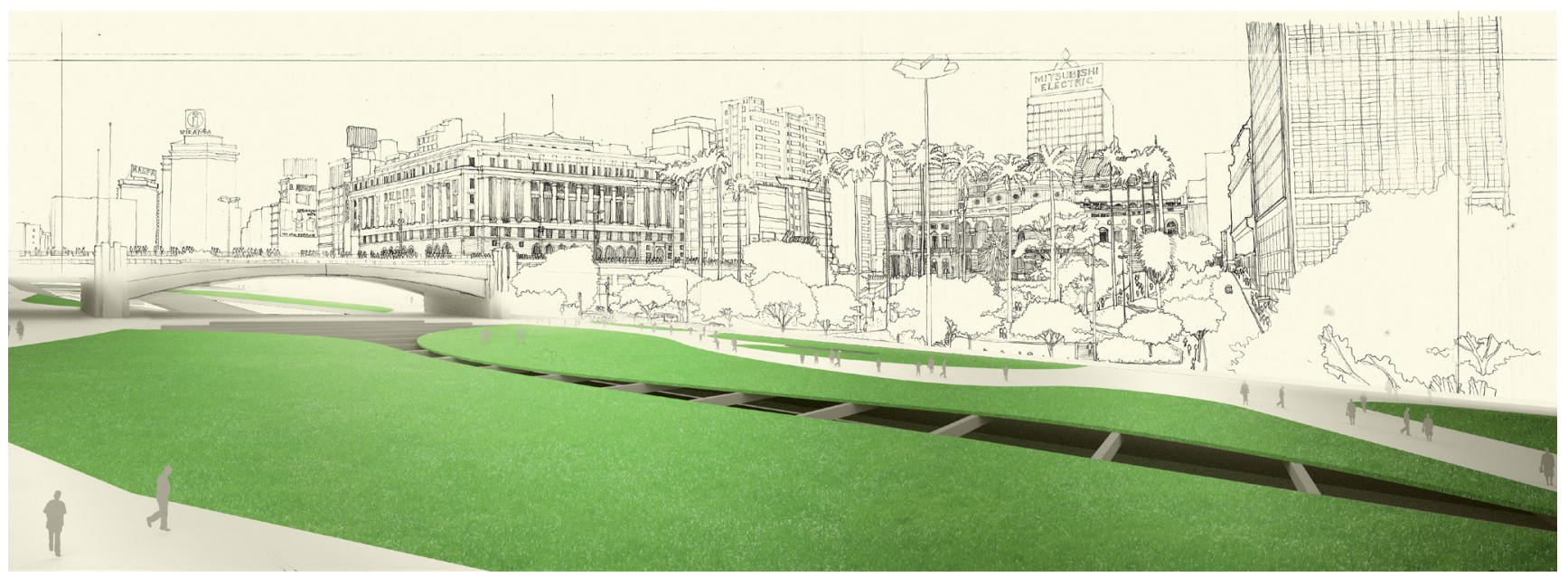

fig.45 Ao lado, foto inserção do projeto de CAG sobre perspectiva à mão de Siegbert Zanettini - Carlos Eduardo Miller e Bhakta Krpa fig.46 A cima, foto inserção do projeto de CAG sobre perspectiva à mão de Siegbert Zanettini - Carlos Eduardo Miller e Bhakta Krpa 


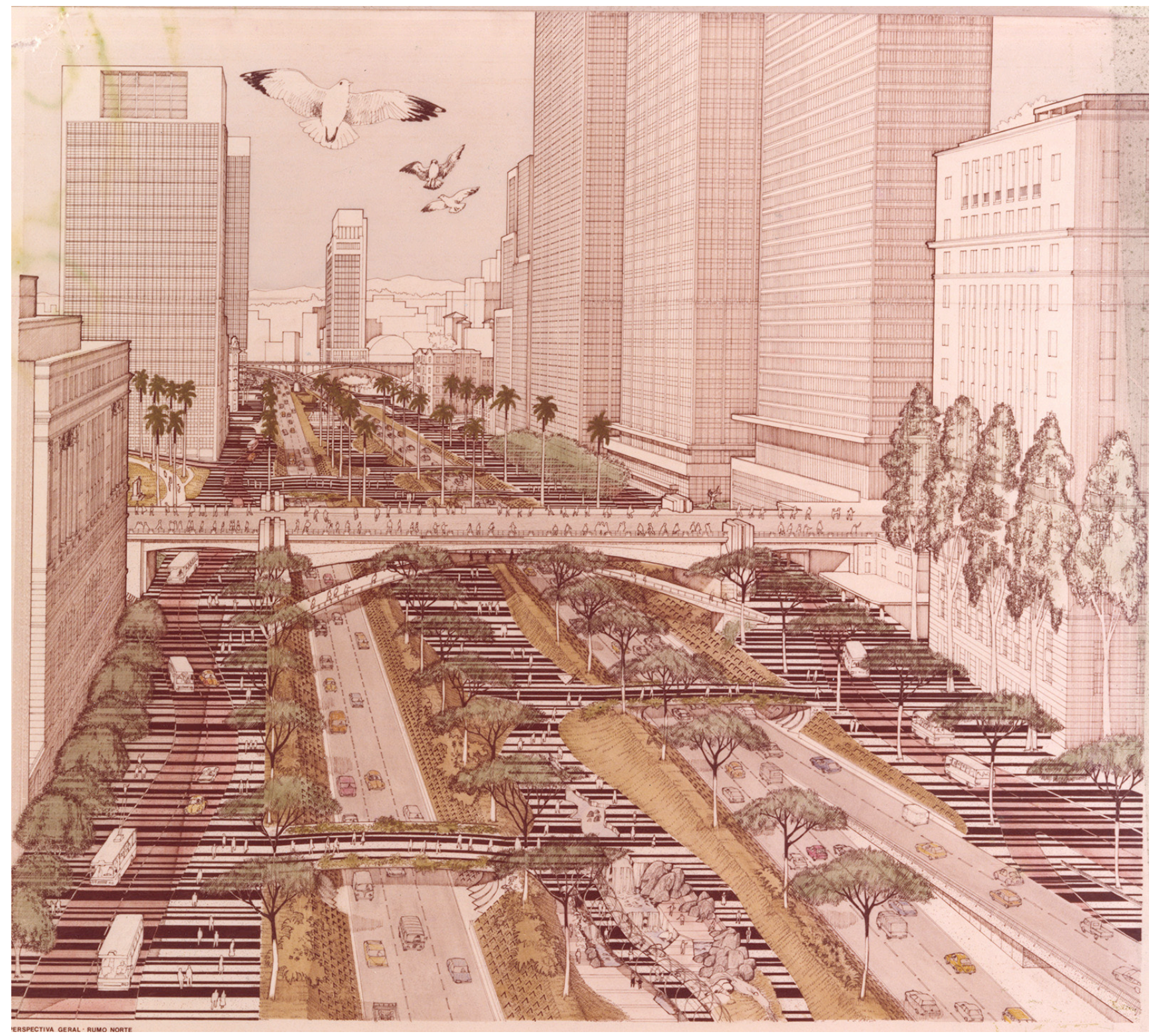

fig.47 Perspectiva do

Vale do Anhnagabaú,

prancha entregue ao

concurso - acervo Julio

Gadelha Barreto

Reurbanização do Vale do Anhangabaú: propostas para recriação de uma paisagem 


\section{Projeto 83 [menção honrosa]}

Autores:

Carlos Bratke - Arquiteto (São Paulo - SP)

Joaquim Cláudio de Oliveira Barreto - Arquiteto (São Paulo - SP)
Colaboradores:

Maria Luísa Giaroli de Oliveira Barreto - Socióloga

Luiz Domingues de Castro Filho - Arquiteto

José Carlos Caparica Olzon - Arquiteto

François Henri Louis Guerin - Projetista

Lídia Matiko Yamana - Arquiteta

Claudia Maria Lavieri Lapetina - Arquiteta

João Luís Marques - Projetista

Jorge M. Abussanra - Estagiário

Inês Cristina Santos Prette - Desenhista

A proposta apresentada pelos arquitetos Carlos Bratke e Joaquim Barreto, ambos graduados em 1967 e pela Faculdade de Arquitetura e Urbanismo Mackenzie apresenta duas estratégias para resolução do conflito entre pedestres e veículos. Para o conflito entre pedestres e automóveis particulares, os arquitetos sugerem a criação de uma série de pequenas passarelas pré-fabricadas que seriam implantadas ao longo dos anos conforme a necessidade. A ideia dos arquitetos era que, com o passar dos anos, a justaposição destas passarelas traria de volta ao Vale "um grande parque, livre das intervenções viárias atuais". ${ }^{13}$

Graças ao rebaixamento parcial pistas de rolagem da Avenida Anhangabaú (aproximadamente $1,5 \mathrm{~m}$ ) e o alteamento também parcial (aproximadamente 2,0m) da parte central do Vale o perfil destas passarelas seria muito baixo, subindo aproximadamente 1,0 metro em relação ao passeio público. Quanto ao conflito entre pedestres e transporte público coletivo, Bratke e Barreto propõem a criação de alamedas compartilhadas que, a partir de seu desenho sinuoso e o tipo de revestimento de piso, realizariam a diminuição da velocidade destes veículos e com isso permitiriam a

13 - A construção São Paulo, número 1755 p. 16 
melhor convivência.

Ainda, em complemento a estas alterações na porção central do Vale, os arquitetos propunham a construção de um novo viaduto e um trevo junto à Rua Carlos de Souza Nazareth, aproveitando assim o desnível entre esta rua e a Avenida Senador Queiroz para auxiliar no desafogamento das ligações norte-sul-norte e de toda rótula de irradiação do centro.

Do ponto de vista do desenho dos espaços livres, Bratke e Barreto propunham a criação de uma alongada ilha (canteiro) central que se estendia por aproximadamente $2 \mathrm{~km}$, dos baixios do Viaduto Eusébio Stevaux até a Avenida Senador Queiroz. Segundo os autores esta "ilha" desempenharia o papel de articular os dois lados do Vale por meio das passarelas pré-fabricadas e de passagens rebaixadas quando necessário (como por exemplo nas proximidades da Avenida São João e Praça Pedro Lessa-Estação São Bento) além de promover também espaços para convívio, oferta de serviços públicos e realização de eventos comunitários. Para proteger os transeuntes das "turbulências" 14 do sistema viário expresso, os autores propuseram um perfil em "U" em toda sua extensão, alterando a altura e o espaçamento entre os taludes laterais ao longo de seu eixo de forma a criar diferentes espacialidades.

Nas laterais do Vale, no trecho entre Praça da Bandeira e Praça Pedro Lessa, os autores propunham a transformação das vias de circulação viária (Rua Formosa e Rua Oposta) em calçadóes mistos, onde haveria o compartilhamento entre pedestres veículos coletivos e oficiais de tráfego lento ${ }^{15}$. Nestes calçadões o piso seria continuo e em nível, havendo a diferenciação da zona exclusiva de pedestre para zona compartilhada apenas por sua coloração.

Em todo Vale seriam plantadas alamedas de arvores (Guapavurus ou Palmeiras Imperiais). Todavia, apesar deste desejo, as áreas ajardinadas seriam restritas aos taludes e à alguns poucos canteiros posicionados em meio aos passeios. No restante do projeto adotou-se mosaico português com desenho paralelo em tons de preto e branco.

Em complemento a estes calçadões mistos e "ilha" central os arquitetos propõem alguns novos programas para o Vale. Iniciando pela porção Sul do Vale, os arquitetos

14 - A Construção São Paulo, número 1755 p.16

15 - Cadernos Brasileiros de Arquitetura, número 16, p. 119. 
sugerem a criação de novo Pavilhão Botânico, uma estrutura de aço e vidro que abrigaria espécies vegetais e promoveria o incentivo ecológico da população. Um pouco mais adiante, atrás do Edifício Touring, aproveitando-se de um terreno desapropriado pelas obras do Metrô, os arquitetos propõem a criação de um novo terminal de ônibus que serviria a Estação Anhangabaú. Solução semelhante seria adotada junto à estação São Bento utilizando-se de um terreno vazio próximo ao baixio do Viaduto Santa Efigênia

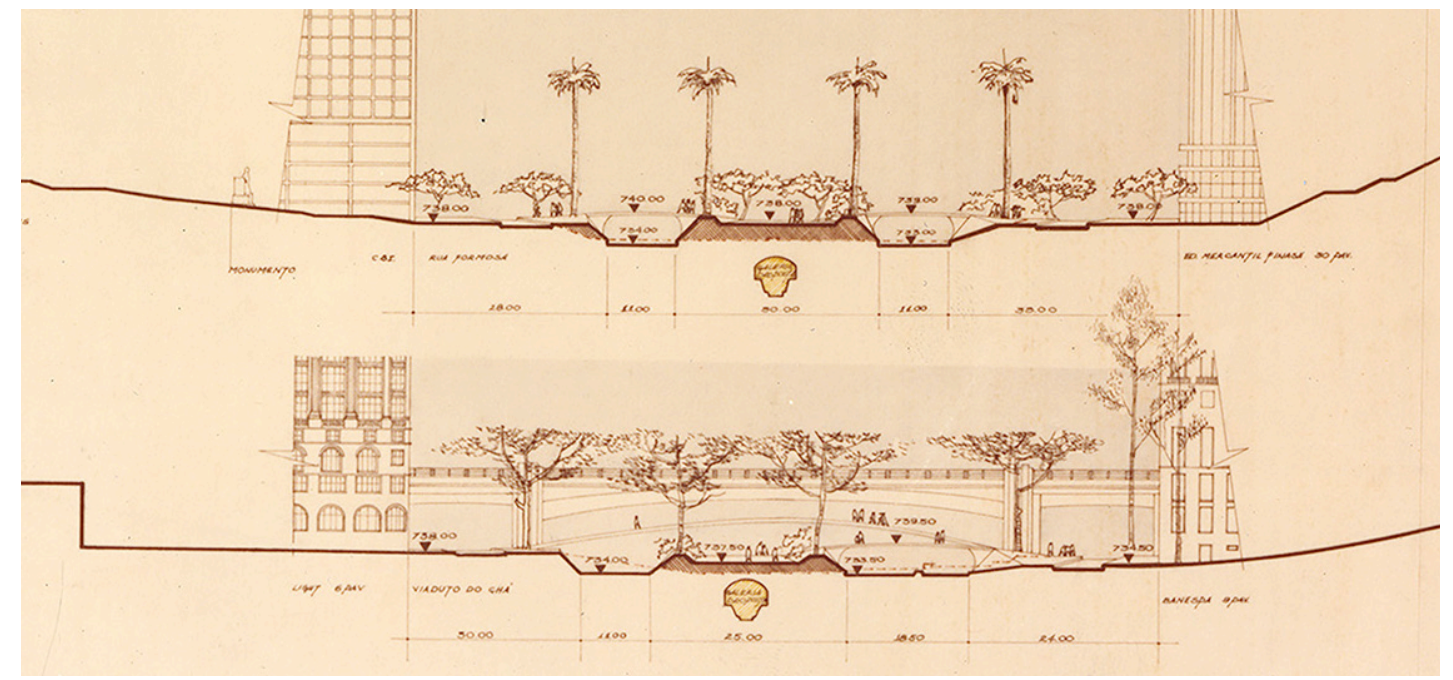

fig.48 Corte tranversal, prancha entregue ao Concurso - acervo Julio Gadelha Barretto

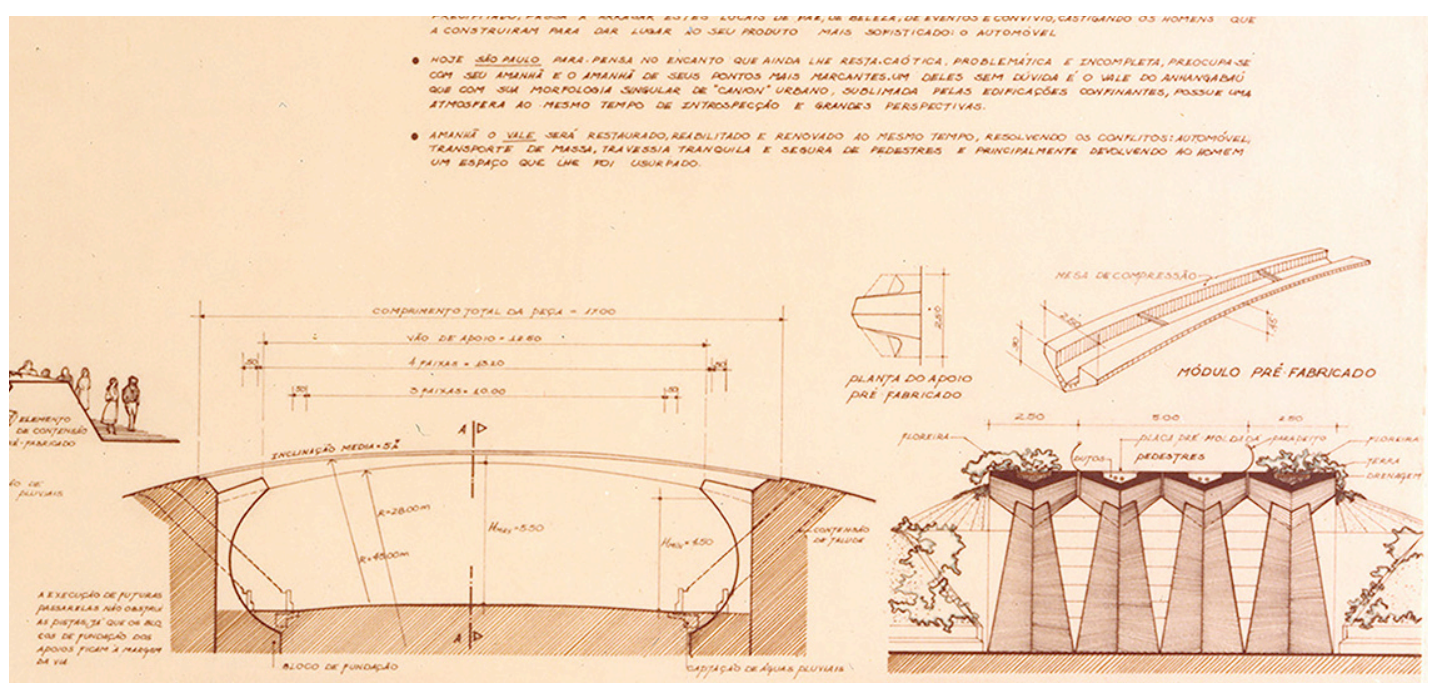

fig.49 Seção pontes pré-fabricadas, prancha entregue ao Concurso - acervo Julio Gadelha Barretto 
No trecho junto ao cruzamento com a Avenida São João, aproveitando-se da estrutura da passagem em nível subterrânea existente (Buraco do Ademar), Bratke e Barreto propõe a criação de um pequeno centro de serviços públicos e coletivos, como por exemplo posto policial, agencia de correios, banca de jornal, etc. Este espaço receberia iluminação zenital e sobre ele seria implantada uma pirâmide de vidro de base quadrada onde cada face receberia um símbolo cardeal e seus rumos, constituindo-se assim em uma Rosa dos Ventos.

Do ponto de vista da regulação, disciplinamento e uso do solo Bratke e Barreto, com o intuito principal de salvaguardar e valorizar os edifícios tombados do Correio, do Conservatório, da Light e do Largo da Memória, propõem a criação de uma legislação especifica para três áreas específicas, dando a elas projeção e gabaritos máximos. Notamos isso na quadra do Edifício Touring, nos lotes vizinhos ao Edifício da Light e nos lotes de esquina defronte ao Prédio dos Correios. Com esta normativa os arquitetos objetivavam permitir que os novos empreendimentos nestas áreas atingissem os mesmos coeficientes dos demais lotes da área central de São Paulo sem, no entanto, bloquearem ou descaracterizarem o patrimônio histórico e ambiental. 


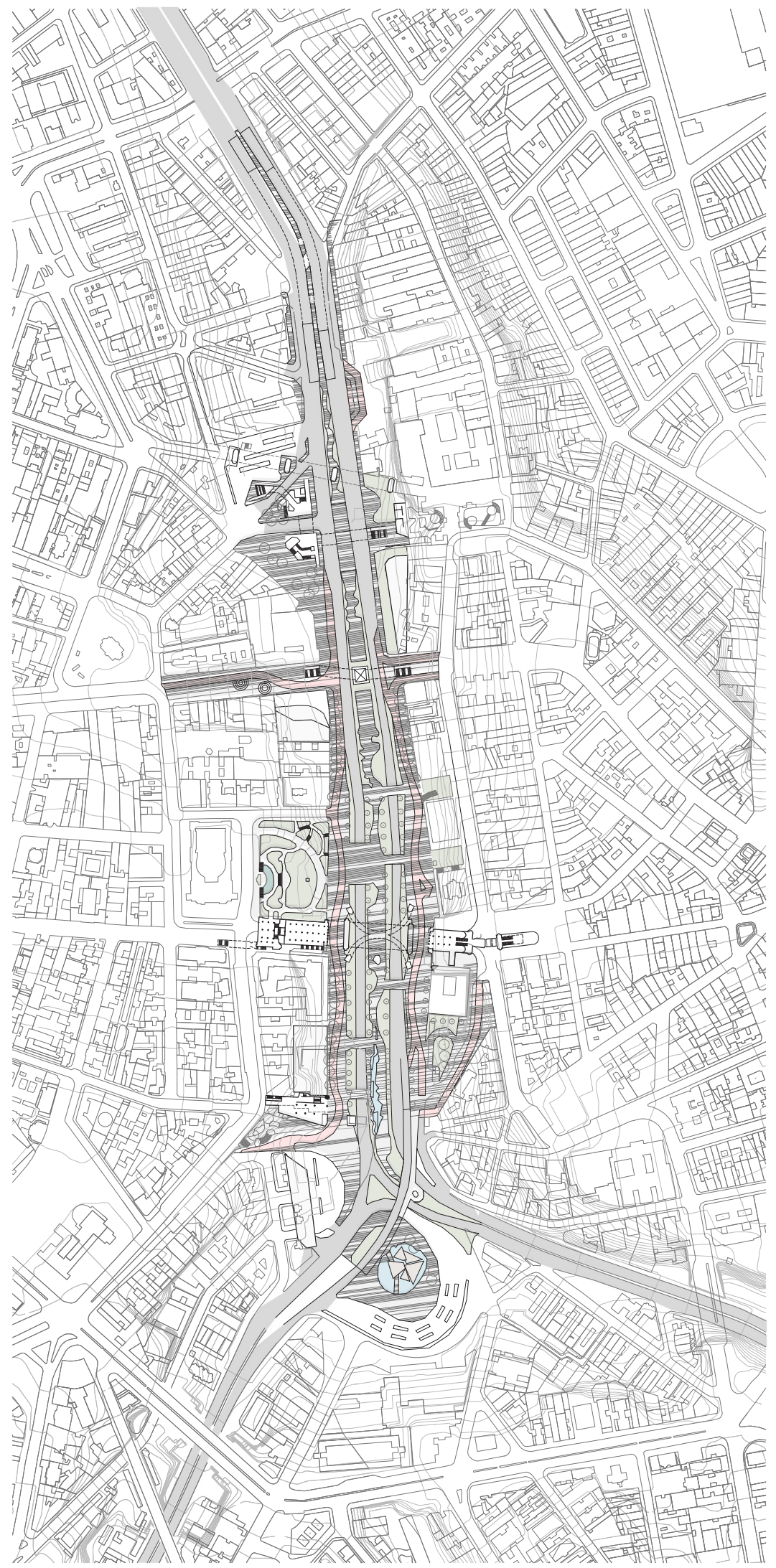

fig.50 Redesenho da propota de Carlos Bratke e Joaquim Barretto. Acervo do Autor

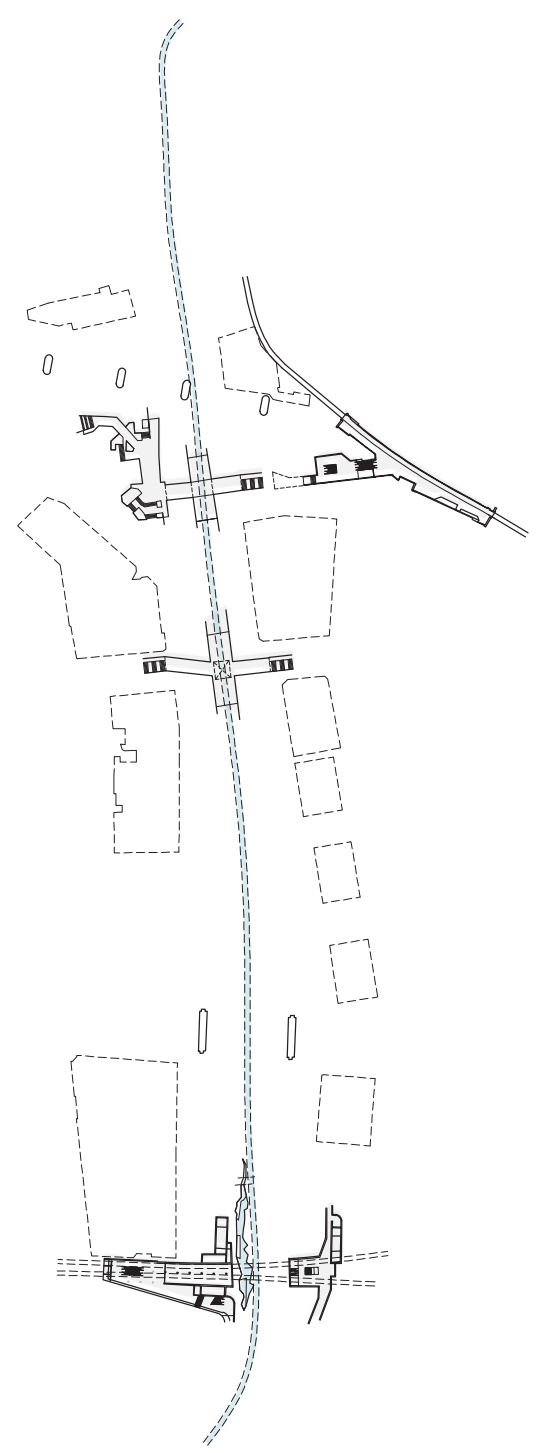

(i)

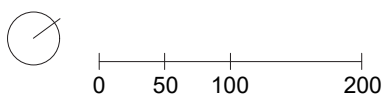




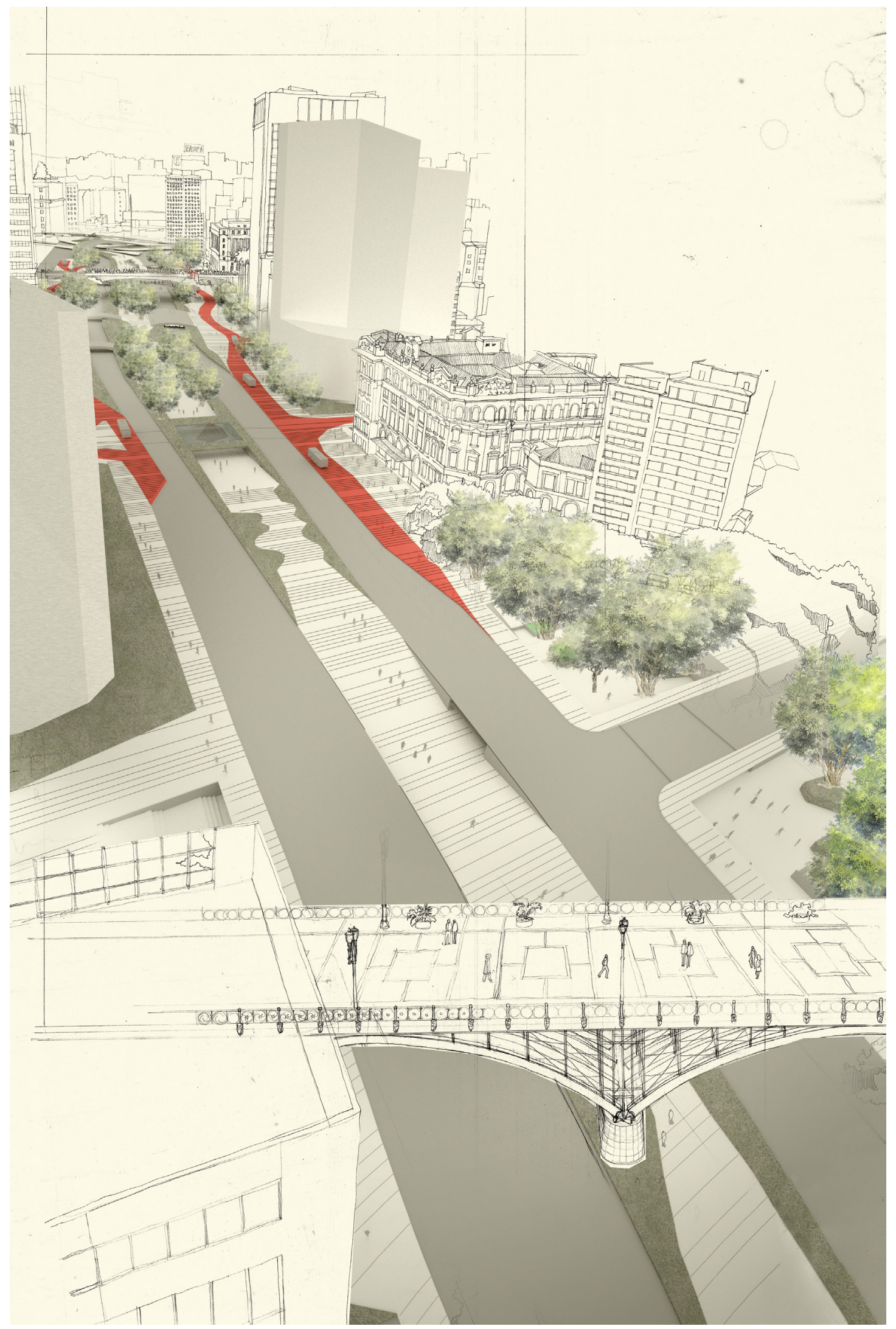




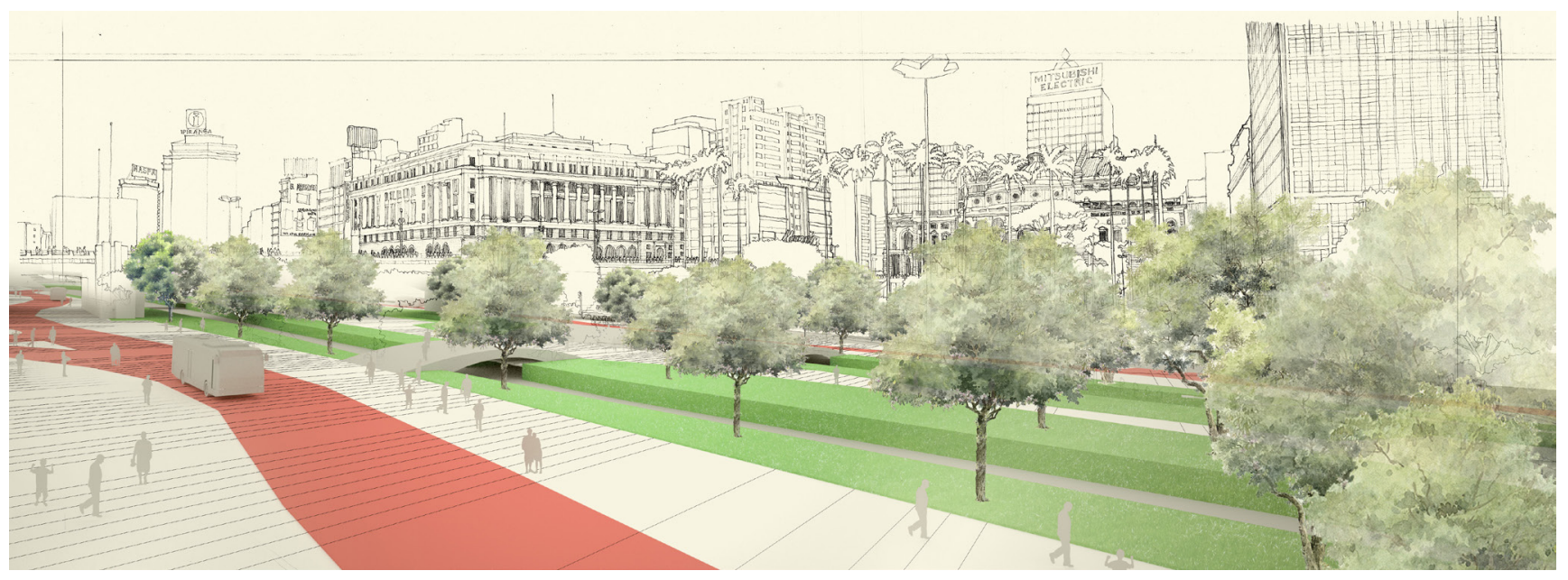

fig.51 Ao lado, foto inserção do projeto de BB sobre perspectiva à mão de Siegbert Zanettini - Carlos Eduardo Miller e Bhakta Krpa fig.52 A cima, foto inserção do projeto de $\mathrm{BB}$ sobre perspectiva à mão de Siegbert Zanettini - Carlos Eduardo Miller e Bhakta Krpa 


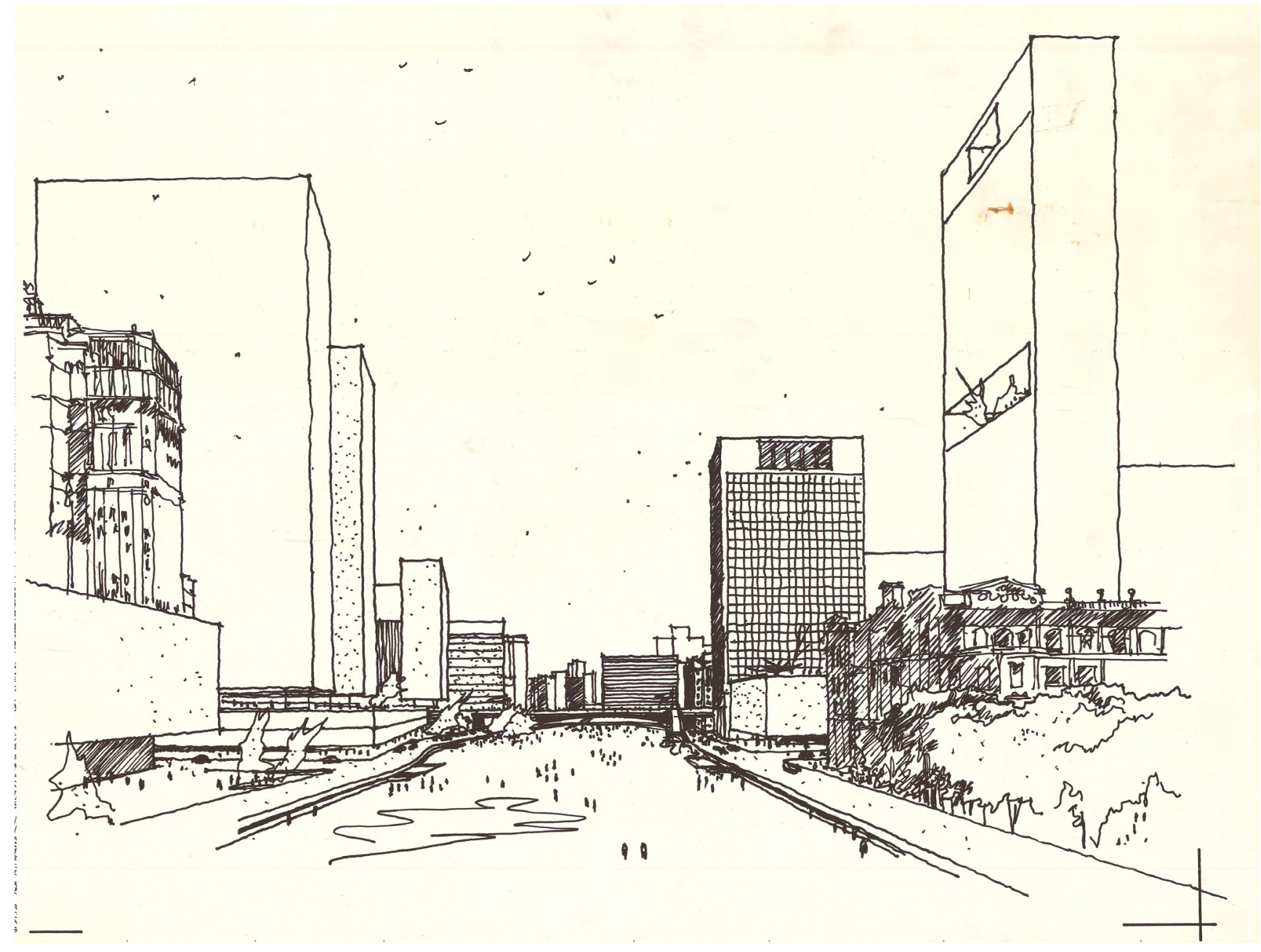

fig.53 Perspectiva do

Vale do Anhnagabaú,

prancha entregue ao

concurso - acervo

Marcos Acayaba 


\section{Projeto 14 [menção honrosa]}

Autores:

Marcos Azevedo Acayaba - Arquiteto (São Paulo - SP)

Edgar Gonçalves Dente - Arquiteto (São Paulo - SP)

Julio Roberto Katinsky - Arquiteto (São Paulo - SP)

A proposta apresentada pelos arquitetos Marcos Acayaba, Edgard Dente e Julio Katinsky, graduados respectivamente em 1969, 1968 e 1957 pela Faculdade de Arquitetura e Urbanismo da Universidade de São Paulo apresenta como resolução para o conflito entre pedestres e veículos uma proposta que parte da readequação viária de todo o trecho compreendido dentro do anel de irradiação do centro de São Paulo ${ }^{16}$. Tal readequação considerava a realização de intervenções não só no trecho específico do Vale do Anhangabaú (Avenidas Nove de Julho, Vinte e Três de Maio, Anhangabaú, Prestes Maia e Tiradentes) mas também nas próprias vias que compunham o anel de irradiação e algumas outras compreendidas dentro de seu perímetro.

Iniciando pelas vias do anel de irradiação, Acayaba, Dente e Katinsky propõem um novo viaduto no cruzamento entre Avenida Prestes Maia e Senador Queiroz, permitindo a eliminação de semáforos e o fluxo continuo nas duas vias.

Internamente ao anel de irradiação a equipe propunha três grandes intervenções. No setor oeste (entre Anhangabaú e Avenida Ipiranga), os arquitetos propunham o retraçado da Rua Conselheiro Crispiniano, conectando assim as Ruas da Consolação e Martins Fontes à Avenida Casper Libero. Para tanto os arquitetos sugeriram a desapropriação e demolição integral de uma quadra vizinha à Praça Dom José Gaspar e parcial de uma quadra junto ao Largo Paiçandu. Já no setor leste (entre Anhangabaú

16 - O Anel de Irradiação do Centro de São Paulo foi proposto por Francisco Prestes Maia e Ulhôa Cintra em 1930 em seu "Plano de Avenidas" e seria formado por avenidas novas e existentes que unidas entre si conformariam um anel viário em torno do centro da cidade. As avenidas que compõem o Anel de Irradiação são: Avenida São Luís a partir da Praça; Viaduto Nove de Julho, Rua Dona Maria Paula; Viaduto Dona Paulina; Praça Dr. João Mendes; Avenida Rangel Pestana; Rua da Figueira; Avenida Mercúrio; Avenida Senador Queirós e Avenida Ipiranga. 


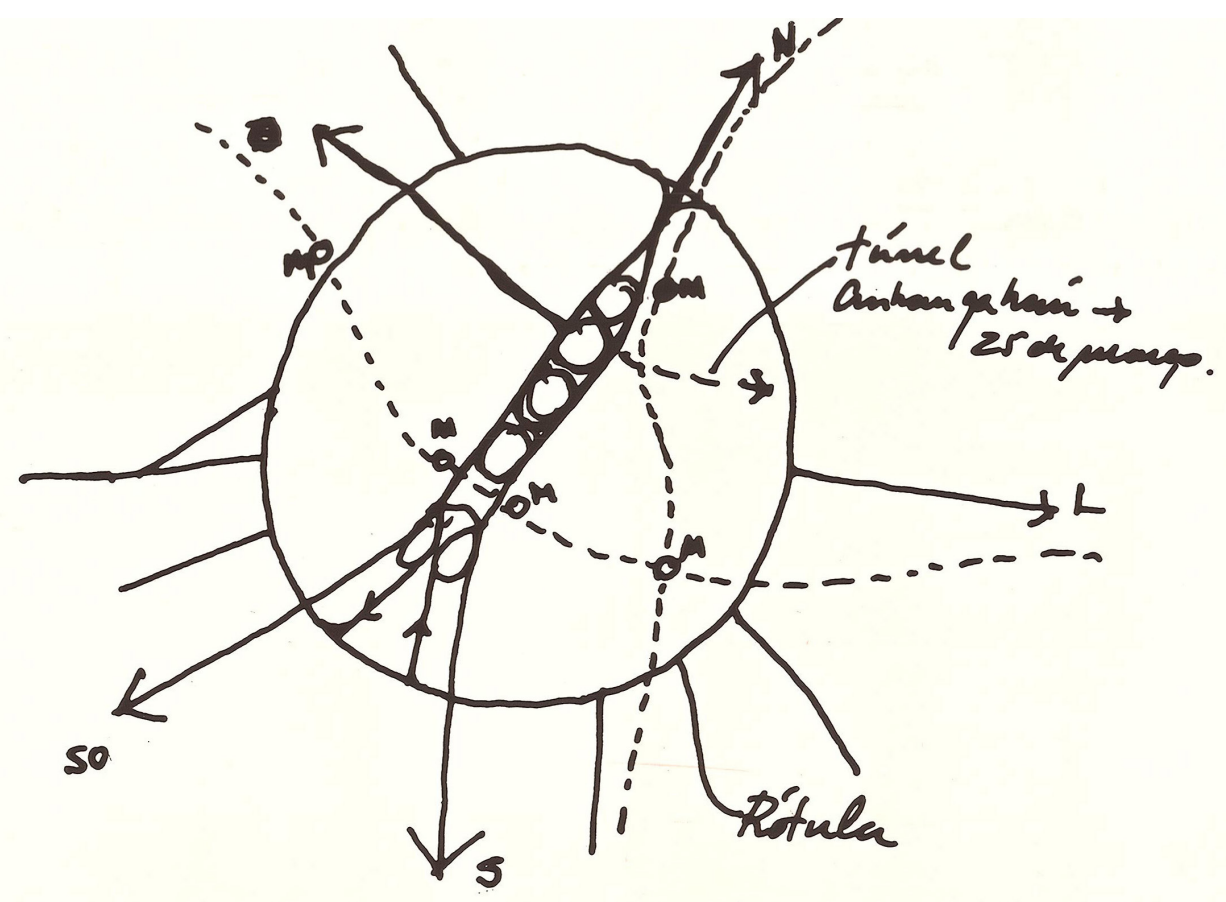

e Praça da Sé, Pátio do Colégio e Avenida Mercúrio) os arquitetos propuseram duas intervenções: a primeira seria o fechamento das ruas Asdrúbal do Nascimento, Travessa Grassi, Rua São Francisco, Rua do Ouvidor, Largo de São Francisco, Rua José Bonifácio, Rua Doutor Falcão Filho e trecho da Rua Libero Badaró e Florêncio de Abreu. A segunda seria resgatar o antigo projeto de túnel ${ }^{17}$ de ligação entre a Avenida Anhangabaú e a região da Vinte e Cinco de Março.

No que diz respeito às vias que constituíam o eixo do Vale propriamente dito (Avenidas Nove de Julho, Vinte e Três de Maio, Anhangabaú, Prestes Maia e São João; e Ruas Formosa e Oposta) Acayaba, Dente e Katinsky propõem um conjunto de soluções que tinham como objetivo final restituir a "cerne da área para o usofruto dos habitantes em suas manifestações quotidianas e especiais"18. Partindo do trecho sul do vale, os arquitetos sugerem a demolição do Viaduto Eusébio Stevaux para a construção de um novo viaduto, este em sentido oposto que conectaria diretamente as avenidas Vinte e Três de Maio e Nove de Julho. Com esta medida, conforme foi explicado por Marcos Acayaba em entrevista concedida em julho de 2015, os arquitetos almejavam não só facilitar a ligação viária Sul-Sudoeste, mas também "corrigir

17 - Em maio de 1914 a Câmara Municipal aprovou um projeto apresentado por Domingos Alves Rubião Meira e Theodulo Cardoso que previa a conexão dos vales do Anhangabaú e do Tamanduateí por meio de um túnel sob a colina histórica

18 - Memorial Descritivo apresentado pela equipe ao Concurso, prancha 2 
a geometria de uma das entradas do Vale, que se fazia de forma confusa pelo Viaduto Eusébio Stevaux e ainda dificultava a travessia de pedestres tanto no sentido longitudinal quanto transversal do Vale". Em complemento a este novo viaduto foram propostas também o prolongamento das Ruas Santo Amaro e Genebra, permitindo assim a conexão direta entre Avenida Anhangabaú e Rua Dona Paula. Na porção que se estende da Rua Doutor Falcão Filho até o Viaduto Santa Efigênia os arquitetos propõem o deslocamento do transito mecanizado para as laterais do vale, realizando assim o alargamento e prolongamento das ruas Formosa e Oposta (nível $+738,0$ ). Ao centro destas duas vias expressas seria construída uma grande esplanada (nível $+734,5)$ de uso exclusivo para pedestres e sob ela dar-se-ia a circulação e parada de ônibus elétricos e transportes coletivos (nível $+730,0$ ). Neste esquema a Avenida São João teria seu fluxo interrompido junto à Rua Formosa.

Passando ao desenho dos espaços livres, Acayaba, Dente e Katinsky concentram seus esforços na criação de uma grande esplanada que, de forma ininterrupta, se estendia do Viaduto Santa Efigênia ao anfiteatro natural formado ao sopé da Câmara de Vereadores. A proposta não considera à conexão direta desta grande esplanada com outras áreas livres já existentes na área, como por exemplo o jardim da Praça Ramos de Azevedo, o Largo da Memória, a Praça Pedro Lessa, o Largo do Patriarca e o Largo São Bento. Antes disso, a proposta desenha este espaço como uma forma muito definida e precisa, balizada em seus bordos leste e oeste pelas vias expressas e a sul pelo edifício da Câmara. Esta independência formal e programática é ainda reforçada pelo desenho de piso, diferente de todos os demais da região e que se torna uma espécie de tapeçaria para ser vista de cima. Não há a previsão de canteiros ou vegetação sobre a esplanada.

Do ponto de vista da programação do espaço não há a previsão de nenhum programa voltado para as demandas cotidianas ou especiais sobre a esplanada. Quanto à este aspecto do projeto o Arquiteto Marcos Acayaba esclarece: "para nós o importante era criar um espaço vazio, sem função definida, em meio ao centro de São Paulo. Um lugar onde as pessoas pudessem se reunir e fazer o que quisessem, de carnaval, como se fazia antigamente, a manifestações políticas"19.

Em contrapartida a este grande "vazio" central os arquitetos propõe um grande con-

19 - Entrevista concedida pelo arquiteto em julho de 2015 

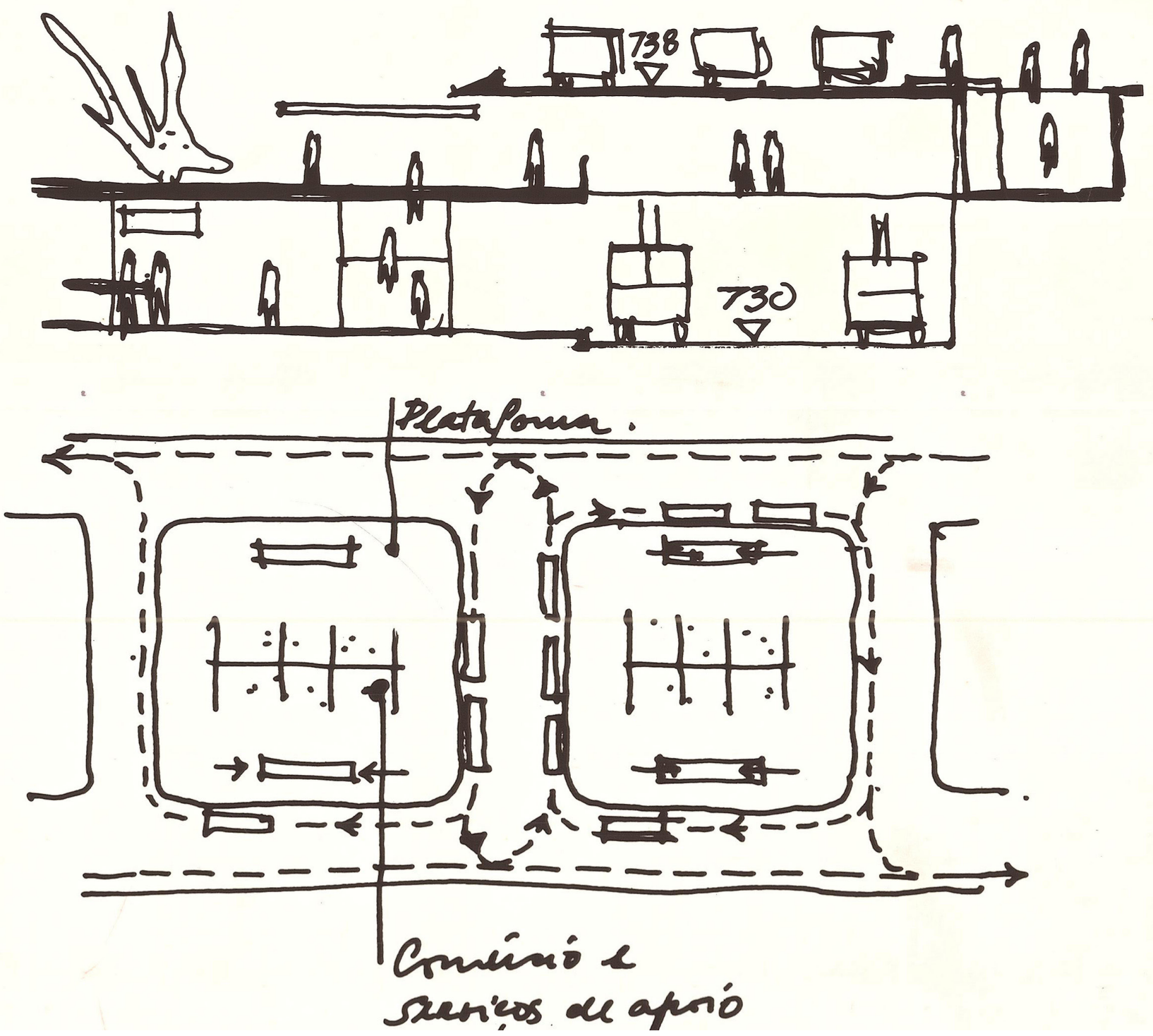

fig.55 Planta e corte

esquemático da estação

central, prancha

entregue ao concurso -

acervo Marcos Acayaba 


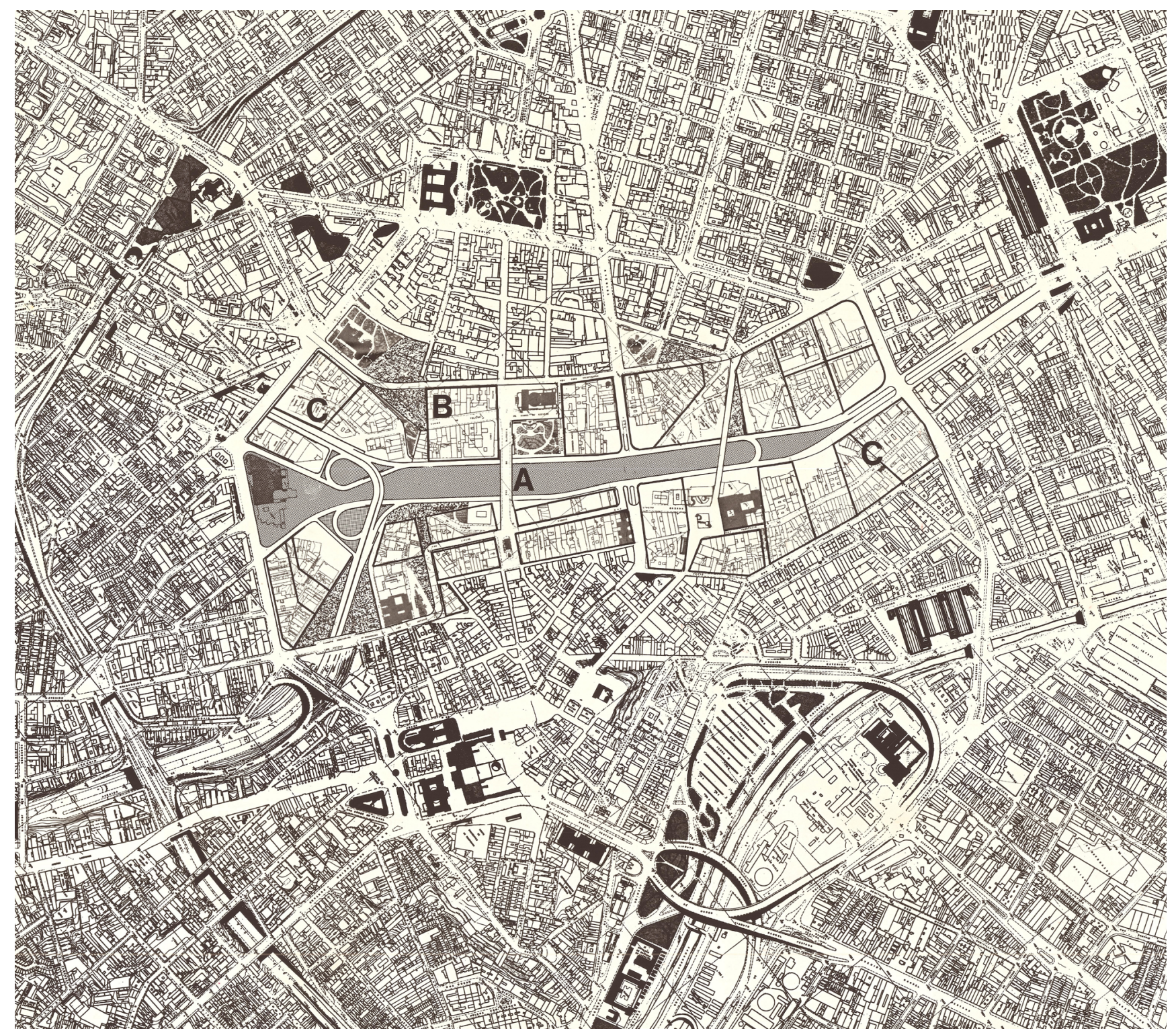

fig.56 Setorização,

prancha entregue ao

concurso - acervo

Marcos Acayaba 
junto de novos programas no entorno do Vale. No extremo sul e no extremo norte do Vale, Acayaba, Dente e Katinsky sugerem a criação da Universidade Municipal (área C no mapa), aproveitando-se assim da infraestrutura já instalada na região (Biblioteca Mário de Andrade, Arquivo Municipal. Além disto os arquitetos propunham que todo o subsolo do Vale (nível $+730,0$ ) funcionasse como uma grande estação de ônibus, uma "estação central capaz de atender 300.000 passageiros/hora" ${ }^{20}$ e que se conectasse diretamente com as estações de Metrô do Largo São Bento e Anhangabaú. Esta estação seria ainda dotada de serviços e postos de atendimento ao público, como por exemplo pequenos comércios, postos de correio, retirada de documentos, etc.

Mas sem dúvida a maior proposição no sentido de novos programas faz-se por meio da sugestão de uma alteração profunda no uso do solo da região do Anhangabaú. Para os arquitetos um dos maiores problemas da região central de São Paulo era o esvaziamento no período noturno, consequência direta do desequilíbrio entre população residente e população flutuante na região. Pensando nisso os arquitetos propõem o remembramento dos lotes do entrono do Vale (área B no mapa) e a construção de novos edifícios baseados em parâmetros construtivos especiais, os quais, em linhas gerais, obedeceriam um coeficiente de aproveitamento de 15 vezes a área do lote (equivalente ao do restante do centro) e obrigatoriamente só poderia ocupar 1/3 da área de projeção a partir de nove metros de altura. Estes novos edifícios poderiam desenvolver qualquer atividade, com exceção de atividades industriais e ainda deveriam resguardar $40 \%$ de sua área total para uso habitacional.

Para a incorporação destes novos edifícios Acayaba, Dente e Katinsky sugerem a criação de uma nova empresa municipal, a qual poderia contar ou não com capital privado. Os proprietários de terrenos e imóveis que fossem ser desapropriados e demolidos poderiam anexar seus bens ao capital da empresa ou serem remunerados no valor equivalente.

Do ponto de vista do patrimônio os autores sugerem que os edifícios tombados pelo patrimônio histórico sejam incorporados à massa construída, aproveitando da ocasião dos novos empreendimentos para inclusive recuperá-los e valorizá-los.

20 - Memorial Descritivo apresentado pela equipe ao Concurso, prancha 2 


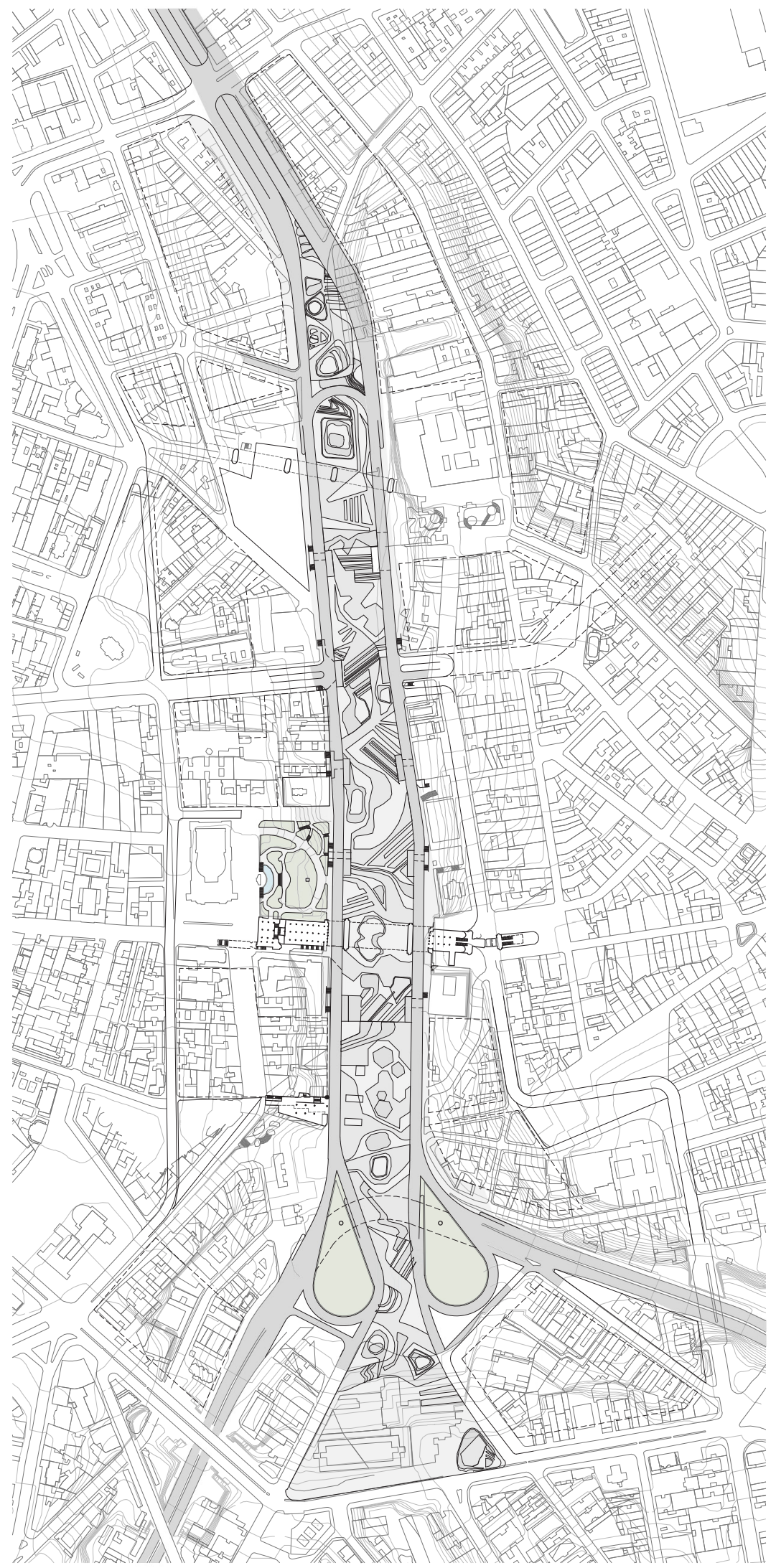

fig.57 Redesenho da propota de MArcos Acayaba, Edgard Dente e Julio Katinsky Acervo do Autor
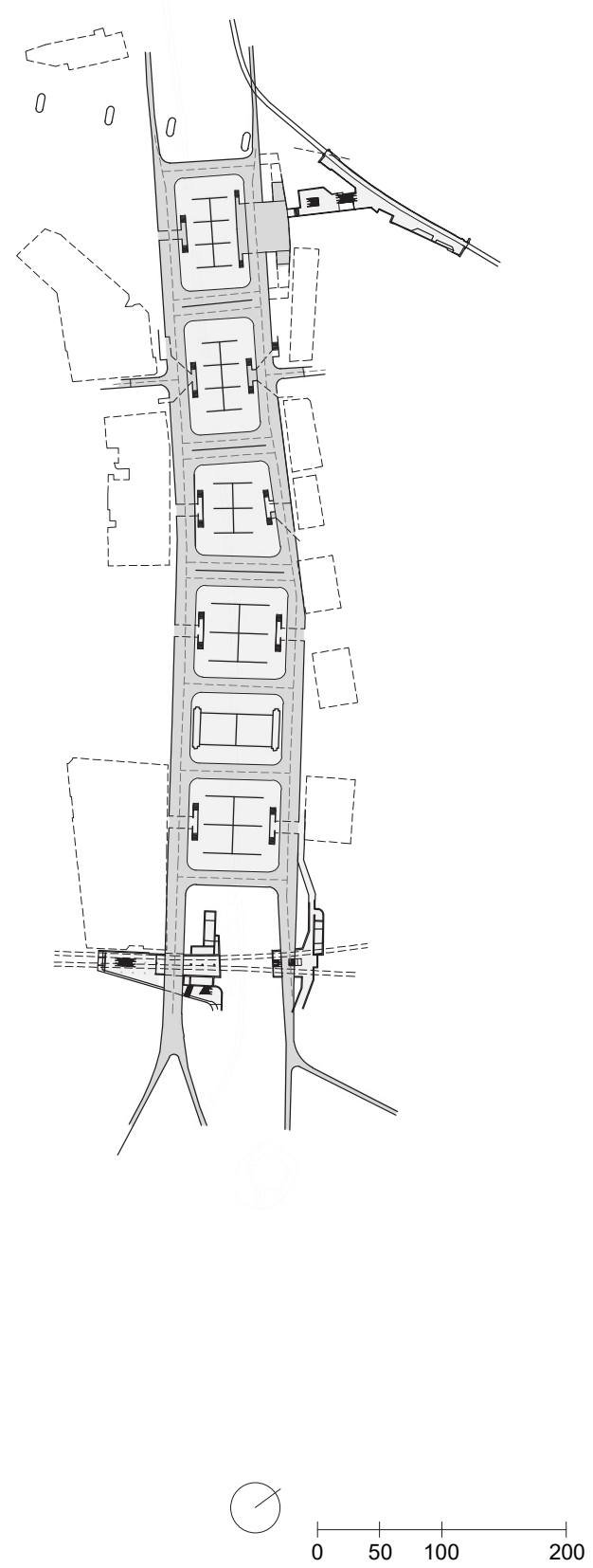


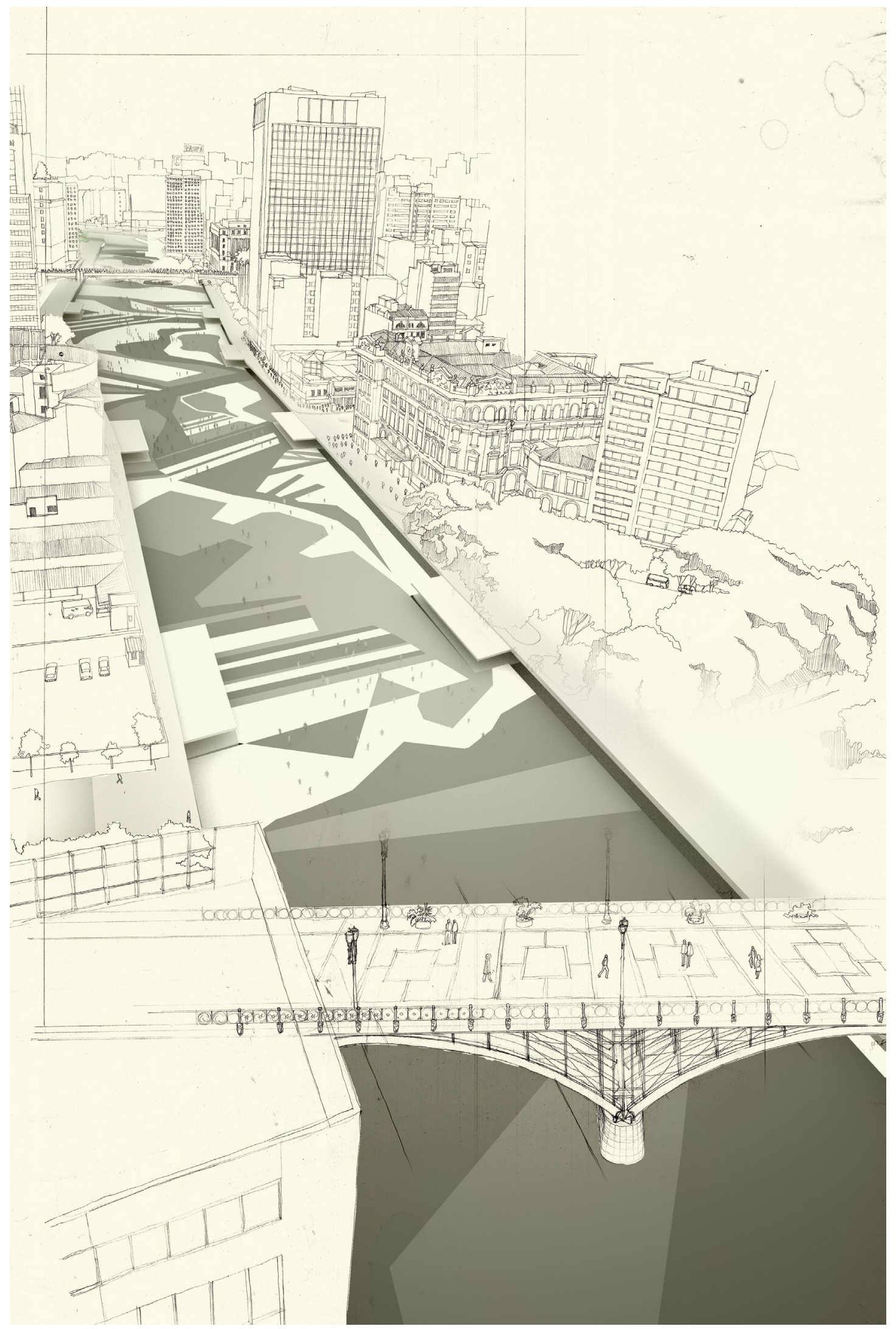




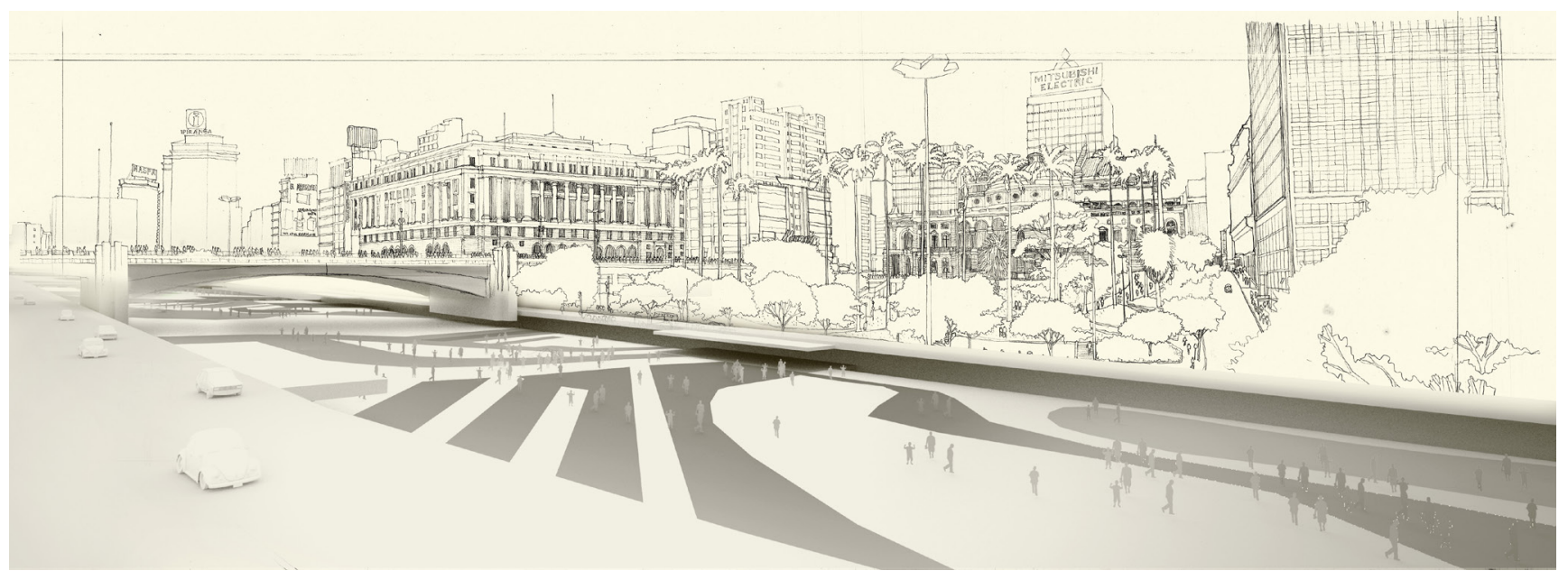

fig.58 Ao lado, foto inserção do projeto de ADK sobre perspectiva à mão de Siegbert Zanettini - Carlos Eduardo Miller e Bhakta Krpa fig.59 A cima, foto inserção do projeto de ADK sobre perspectiva à mão de Siegbert Zanettini - Carlos Eduardo Miller e Bhakta Krpa 
Reurbanização do Vale do Anhangabaú: propostas para recriação de uma paisagem 


\section{Projeto 15 [menção honrosa - não localizado]}

Autores:

Joel Ramalho Junior - Arquiteto (Curitiba - PR)

Leonardo Oba - Arquiteto (Curitiba- PR)

\section{Projeto 20 [menção honrosa - não localizado]}

Autores:

Celso Hironobu Tanaka - Arquiteto (Curitiba - PR)

Paulo Yoshikatsu Kawahara - Arquiteto (Curitiba- PR)
Colaboradores:

Luiz Carlos de Góes - Estagiário Silvio Teixeira Jardim - Estagiário Almir Shigueiti Sakagushi - Estagiário Roberto Rodrigues Simon - Estagiário Ênio de Aragon Ferreira - Estagiário 


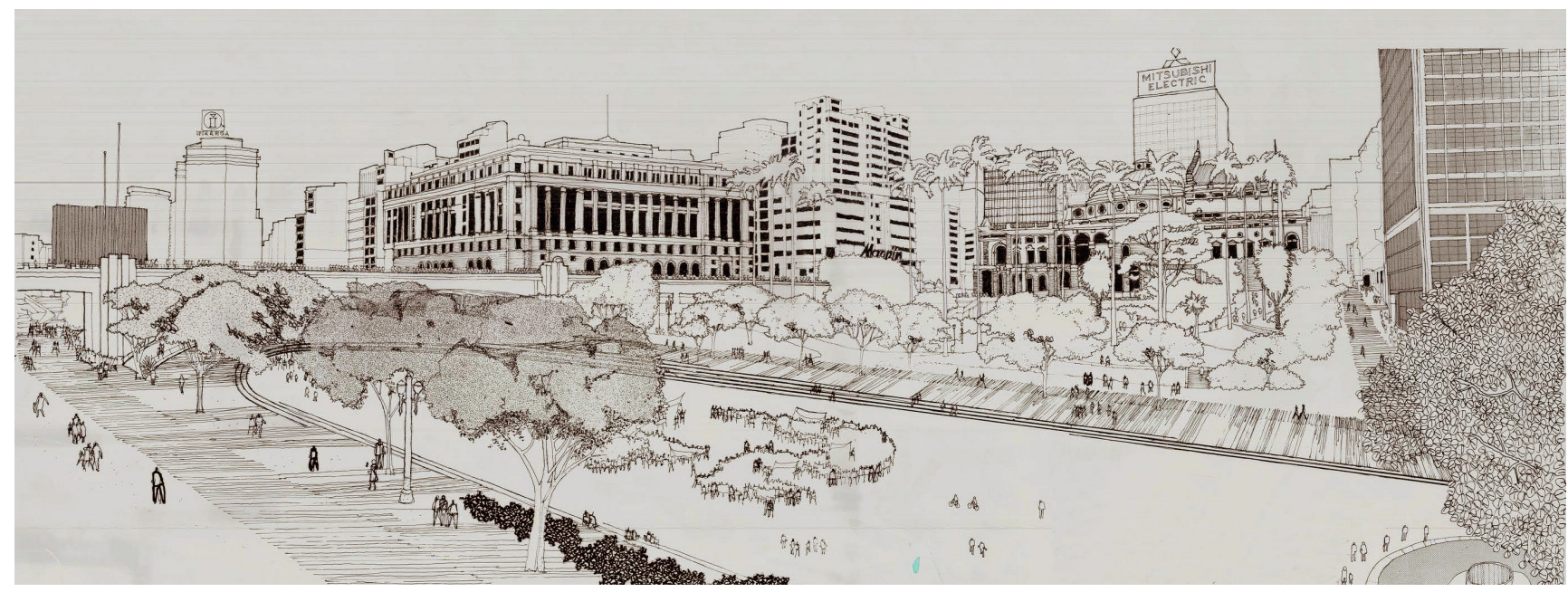

fig.60 Perspectiva do Vale do Anhnagabaú, prancha entregue ao

concurso - acervo

escritório APBA 


\section{Projeto 16 [ $3^{\circ}$ prêmio]}

Autores:

Paulo Bastos - Arquiteto (São Paulo - SP)

Siegbert Zanettini - Arquiteto (São Paulo - SP)
Colaboradores:

José Sales Costa Filho - Arquiteto

Newton Massafumi Yamamoto - Arquiteto

Maria de Fátima Araújo - Arquiteta

Roberto Israel Eisenberg Saruê - Arquiteto

Mirthes Ivany Soares Baffi - Arquiteto

Miriam Lobel - Arquiteta

Vanderlei Nunes Collange - Arquiteto

Antônio Brazão Rodrigues - Arquiteto

José Antônio Henrique - Arquiteto

Carlos David Nassi - Engenheiro / Transportes

Ana Lucia Brasil - Engenheira / Saneamento

Walter Vaccaro - Engenheiro / Ventilação

Aluísio Amaral Monteiro Leite - Engenheiro /

Custos

Luiz Morales Davila - Engenheiro / Técnica

Construtiva

Wagner Amodeo - Estagiário

Partindo do princípio de que a resolução do conflito entre pedestres e veículos não deveria ser vista como uma mera questão de circulação, mas ir além e encarada como uma questão de retomada dos usos, atividades e contato humano no espaço urbano ${ }^{21}$, a proposta apresentada pelos arquitetos Paulo de Mello Bastos e Siegbert Zanettini, graduados pela Faculdade de Arquitetura e Urbanismo da Universidade de São Paulo em 1959 e 1957 respectivamente, elege como ponto central para a resolução deste conflito a restituição ao pedestre da superfície do Vale, sobretudo em seu trecho mais ativado, compreendido entre os viadutos do Chá e Santa Efigênia. Com isto os arquitetos tencionam recolocar o Homem em meio ao "espaço físico e ao verde nascendo do chão" 22 . Os automóveis individuais, por sua vez, são transferidos para o subsolo e 21 - "A visão que compreende e aceita o Vale apenas como uma calha viária, portadora de um fluxo crescente de veículos, também encara o outro protagonista, o pedestre, em termo de outro fluxo, conflitante com o primeiro. (...). Não aceitamos a questão nestes termos. Ela é muito mais ampla e compreende a solução do conflito pedestre $\mathrm{x}$ veículo no quadro maior de uma retomada dos usos dos espaços urbanos pela população no qual a circulação, tanto de pedestre como do veículo, tem que dar-se em função dos novos usos e não ao contrário" -Revista Projeto, n. 31 - p. 48

22 - Revista Projeto, n. 31 - p. 50 
tem seu fluxo desimpedido.

Quanto aos veículos de uso coletivo, os arquitetos não consideram que haja um real conflito entre estes e os pedestres e por isso preveem o simples remanejamento de suas paradas para a criação de uma mini-rótula de distribuição de transporte no centro, constituída pelas ruas Xavier de Toledo, Viaduto do Chá, Libero Badaró e Avenida São João.

Para o desenho dos espaços livres os autores se basearam na percepção da "estrutura" do Vale e seus arredores ${ }^{23}$ para a definição das características, programas e espacialidades a serem criadas. Para tanto, Bastos e Zanettini realizam um profundo levantamento morfológico do Vale do Anhangabaú e seu entrono por meio de visitas de campo, levantamento fotográfico, entrevistas e levantamentos das atividades desenvolvidas pelos usuários da região. Deste levantamento resulta um diagrama-síntese que resume a "estrutura" do Anhangabaú em cinco eixos:

Eixo 1 - Eixo pelas ruas Direita e Barão de Itapetininga ligando os polos Sé e República, principal conexão da área central definida pela sobreposição de duas ligações fundamentais: uma superior possibilitada pela existência do Viaduto do Chá em mesma cota dos "platôs" e outra inferior, interrompida pelo bloqueio da escada defronte ao Teatro Municipal e do fechamento do espaço contiguo ao viaduto.

Novamente abertos à circulação e ao uso estes espaços dariam continuidade ao fluxo da Galeria Prestes Maia.

O eixo é caracterizado do ponto de vista espacial por uma sucessão crescente de espaços que vão da pequena largura das ruas Direita e Barão, passando pelos espaços intermediários das praças do Patriarca e Ramos de Azevedo até o grande espaço do Vale.

Eixo 2 - Eixo formado pelas ruas Boas Vista e Santa Efigênia ligando os polos próximos ao Colégio São Bento e Igreja de Santa Efigênia.

O quadro é o mesmo do eixo anterior - conexão sobrepostas em dois níveis, um superior pelo leito do Viaduto Santa Efigênia; e outro inferior pela estação São 23 - "O entorno próximo revelou à observação o rico conjunto de e elementos que emolduram e envolvem o Vale, formando (...) complexa gama de texturas, cores, cheios e vazios, luzes e sombras. (...) foi se redescobrindo assim cada viela, cada canto, cada "piazzeta", cada visual, cada detalhe (...). Nesse ponto era necessário entendê-lo, captar-lhe a individualidade e fazer aflorar a sua estrutura espacial". Revista Projeto, n.31 - p. 51 


\section{Bento do Metrô.}

Do ponto de vista espacial este eixo também apresenta uma sucessão de espaços crescentes, com a diferença que o espaço maior encontra-se em meio a Praça Pedro Lessa, espaço densamente arborizado.

Eixo 3 - Eixo constituído pelas ruas XV de Novembro e Avenida São João inicia também na Sé e estende-se ao longo da avenida. Mais uma vez ocorre uma sucede-se uma sequência de espaços estreitos, caso da Rua XV de Novembro, e intermediários - Praça Antônio Prado e Largo Paiçandu - até confluir no espaço do Vale.

Este eixo, entretanto, estabelece-se como centro de gravidade do Vale uma vez que reúne o maior número de atividades e pessoas na região.

Eixo 4 - Eixo mais periférico, porém historicamente importante como tradicional travessia do Vale completa este conjunto de eixos tranversais. Conformado pelos polos Ladeira da Memória, Praça da Bandeira e Largo São Francisco este eixo apresenta grandes obstáculos à travessia de pedestres devido a conturbada área ocasionada pelas passagens d Avenida Nove de Julho e Vinte e Três de Maio.

Eixo 5 - As ruas Formosas e Anhangabaú que devido à suas condições naturais apresentam-se como terraços naturais e conectam os diferentes eixos transversais ao Vale.

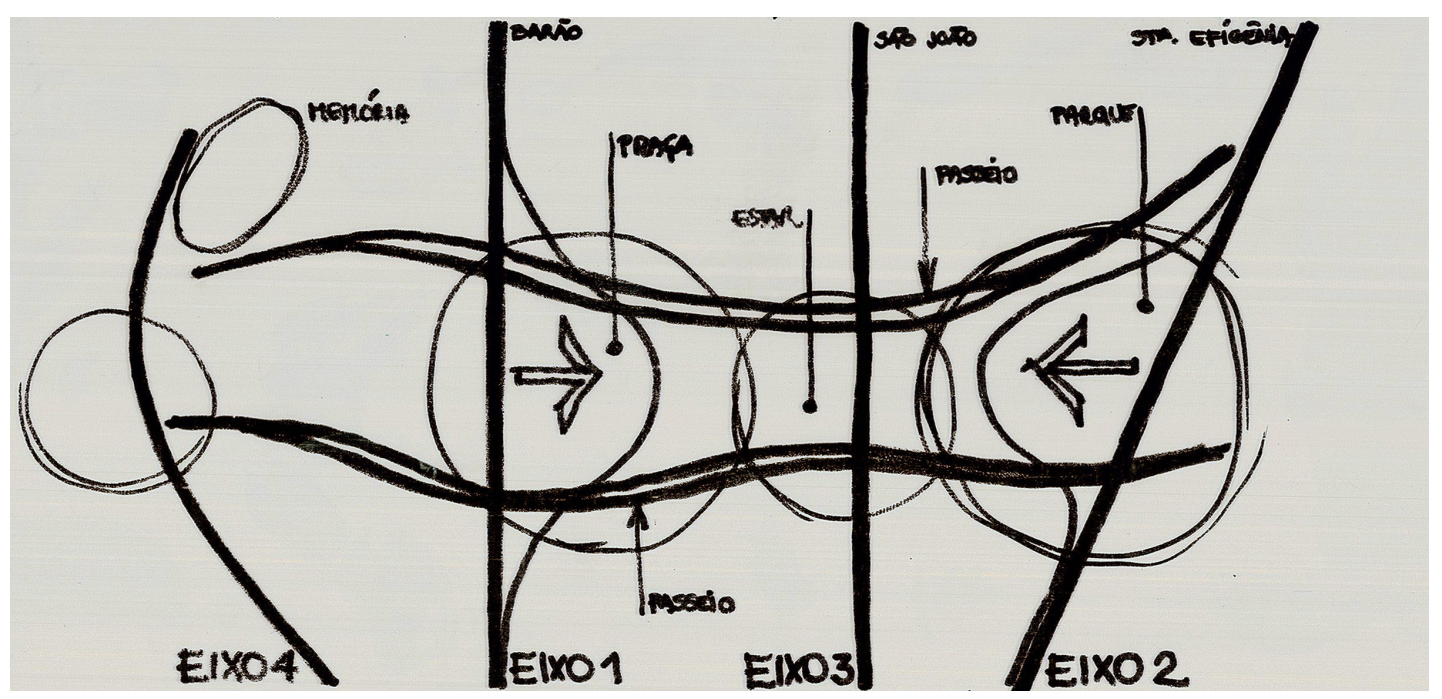


É a partir da definição destes eixos que Bastos e Zanettini propõem a criação de três novas praças no leito do Vale que se portariam como "elos" de ligação entre as margens Leste e Oeste do Vale. Iniciando pelo eixo das ruas Direita e Barão (eixo 1) os arquitetos preveem a criação de uma praça cívica, aberta e livre, somente pavimentada que recuperaria o anfiteatro natural como espaço de encontro e manifestações populares.

Para o eixo definido pelas ruas Boa Vista e Santa Efigênia (eixo 2), Bastos e Zanettini optam por aproveitar a densa arborização pré-existentes na região da Praça Pedro Lessa para conformar uma "praça-parque"24. Ainda, visando uma melhor conexão entre a Rua Libero Badaró e a Avenida Prestes Maia, os autores sugerem a incorporação de um terreno vago vizinho à estação São Bento do Metrô.

Já para o eixo definido pela Rua XV de Novembro e Avenida São João, os arquitetos sugerem a realização de uma praça de estar, capaz tanto de absorver os frequentadores e usuários daquele que seria o centro de gravidade do vale quanto realizar a transição e conexão entre a praça cívica e praça-parque.

Por fim, aproveitando-se de sua disposição ao longo das encostas e reforçando o caráter das três praças (cívica, estar e parque), Bastos e Zanettini propõem que as ruas Formosa e Anhangabaú (eixo 4) sejam transformadas em dois passeios laterais densamente arborizados.

Complementando estes novos espaços públicos junto ao Vale os arquitetos propõem a programação e readequação de outras áreas públicas subutilizadas ou fechadas, como por exemplo os baixios do Viaduto do Chá, a passagem subterrânea para a Praça Ramos e a Galeria Prestes Maia. Para tanto sugerem que a Secretária Municipal de Cultura, por meio do Departamento de Teatro da (IDART-SP) e o Departamento do Patrimônio Histórico (DPH-SP), realize nestes espaços atividades culturais que permitam a identidade da população com o espaço do Centro.

Do ponto de vista do uso e ocupação do solo a proposta de Bastos e Zanettini pressupõe a criação de uma nova legislação a ser implementada a longo prazo para toda a área central. Esta nova legislação, diferentemente da atual, se basearia em projetos 24 - Praça-parque é o termo utilizado pelos autores para se referirem à um espaço público com dimensão semelhante à de uma praça porém com espacialidade, vegetação e equipamentos semelhantes à de um parque. 


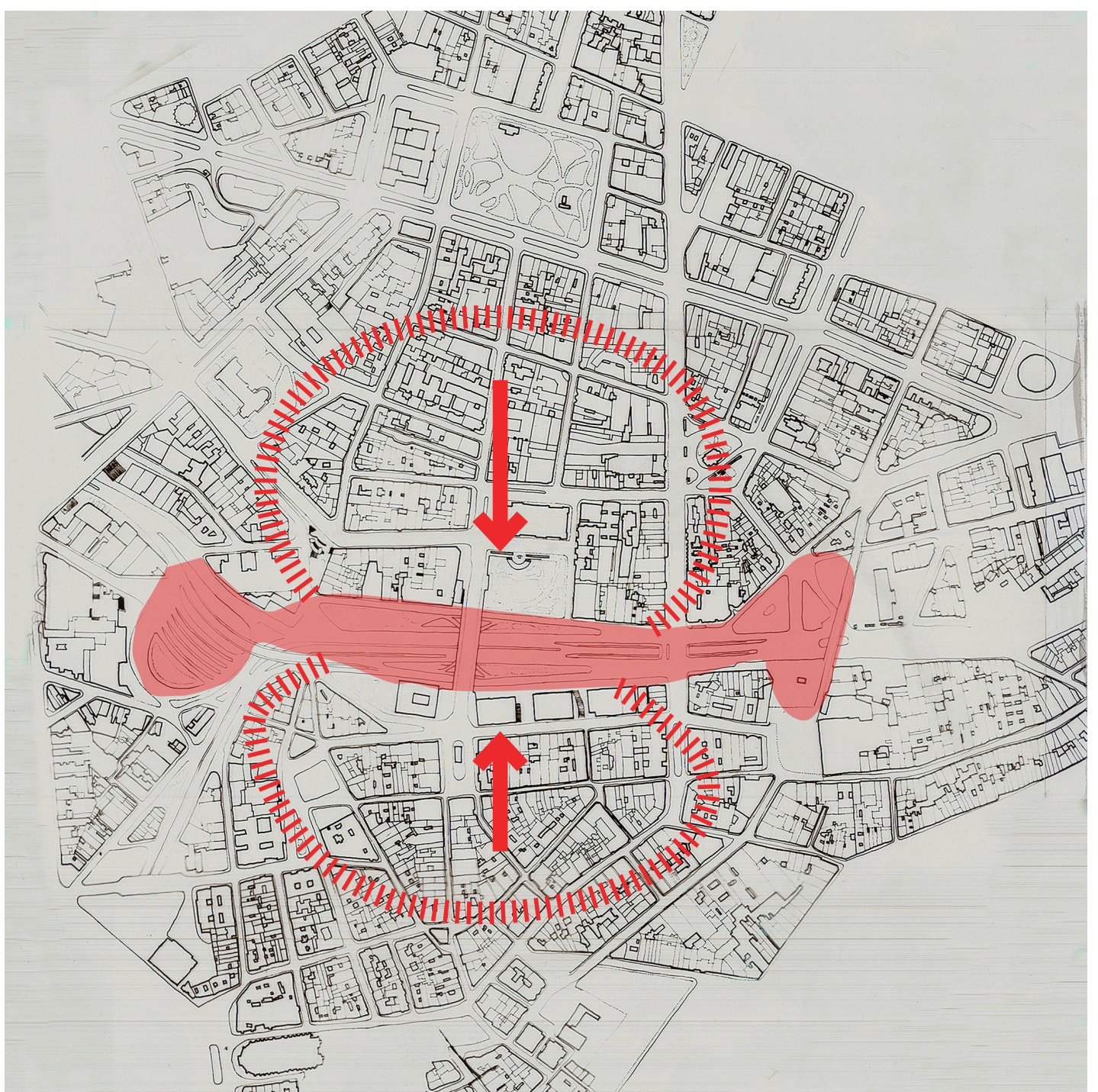

fig.62 Diagrama de conceitual de intenções, prancha entregue ao concurso - acervo escritório APBA

feito quadra a quadra e no caso de novas edificações observaria a relação do gabarito pretendido versus a largura das ruas e a recomposição da volumetria dos quarteirões (relação novos edifícios com os já existentes). Com relação aos usos do solo esta nova legislação proporia por um lado o incentivo de alguns usos específicos a fim de evitar o seu desaparecimento e por outro a delimitação física de outros.

Para a viabilização desta nova legislação os arquitetos sugerem a utilização de mecanismos de incentivo tais como isenção fiscal, aplicação de solo criado e instituição de ajuda técnica e financeira por parte do poder público.

Quanto a preservação e valorização do patrimônio histórico, Bastos e Zanettini propõem que esta não se dê somente a nível dos elementos já identificados pela Z8200, mas que se estenda para todo o conjunto significativo presente na região. Neste

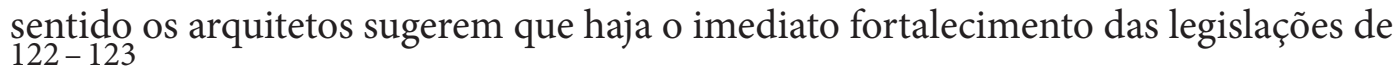



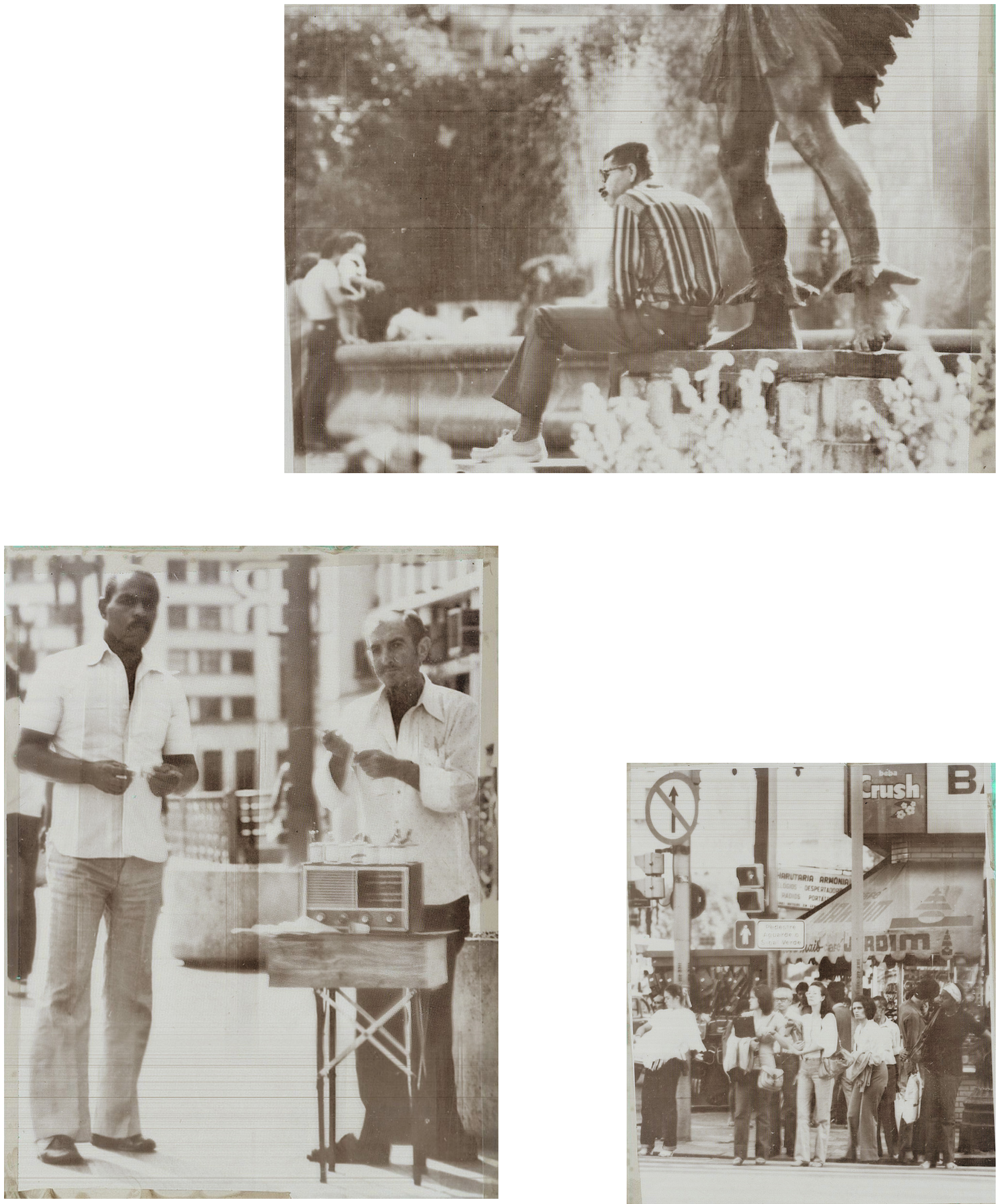

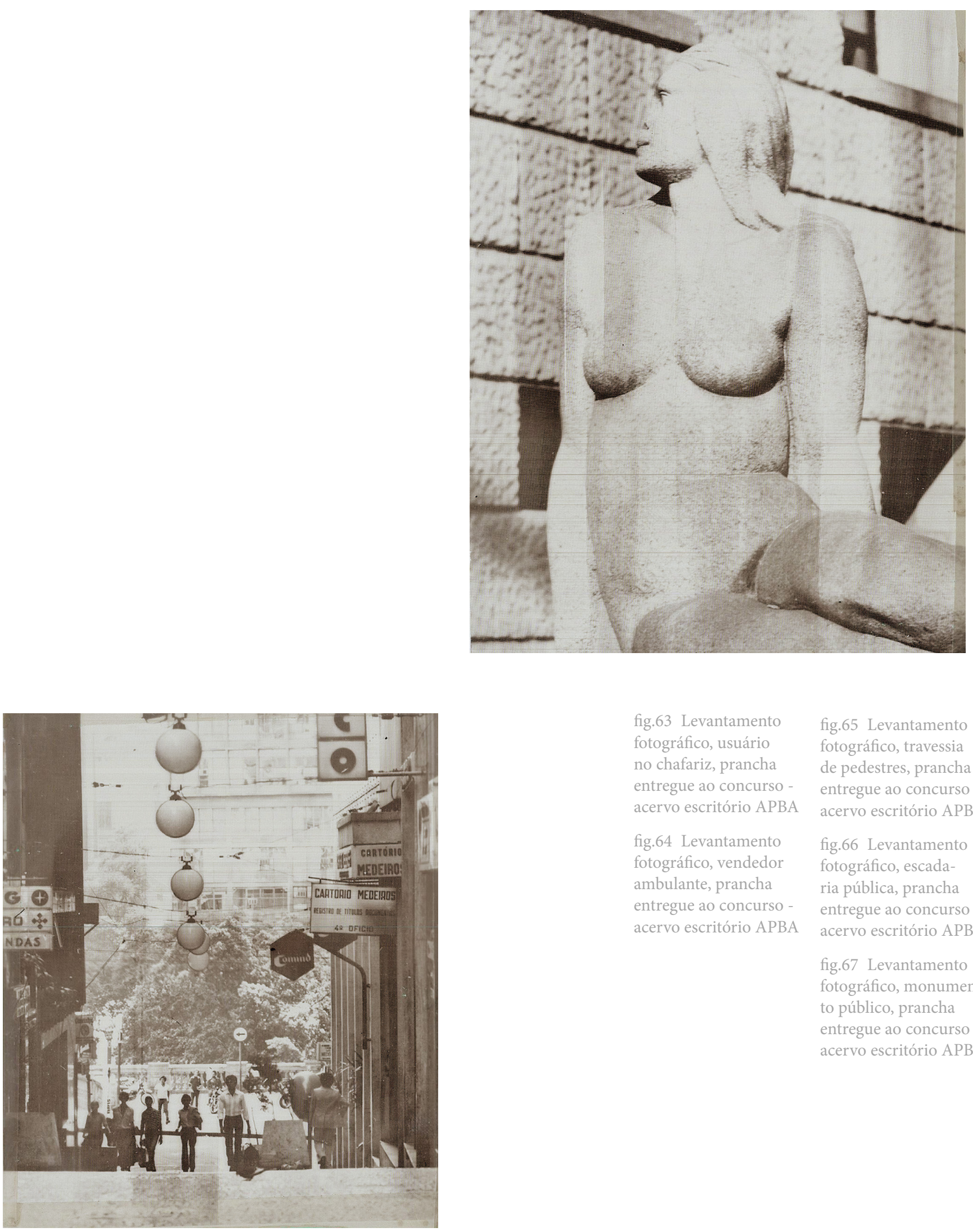

fig.63 Levantamento fotográfico, usuário no chafariz, prancha entregue ao concurso acervo escritório APBA

fig.64 Levantamento fotográfico, vendedor ambulante, prancha entregue ao concurso acervo escritório APBA fig.65 Levantamento fotográfico, travessia de pedestres, prancha entregue ao concurso acervo escritório APBA

fig.66 Levantamento fotográfico, escadaria pública, prancha entregue ao concurso acervo escritório APBA

fig.67 Levantamento fotográfico, monumento público, prancha entregue ao concurso acervo escritório APBA 
preservação existentes, incorporando mecanismos em estudo pela COGEP como incentivos fiscais e solo criado, assim como a imediata dinamização da Comissão de Proteção à Paisagem Urbana, tornando-a mais ativa e atuante no disciplinamento da publicidade e na liberação das fachadas recobertas por painéis e a efetiva aplicação do raio de proteção de 300 metros aos monumentos tombados.

Além desta atuação a nível legal, a proposta dos arquitetos prevê a liberação de logradouros que sofreram ocupação ou remanejamento indevido e a criação de novos espaços públicos, como a área nas proximidades da Ladeira da Memória e a área junto ao muro de arrimo da Casa da Bóia, desapropriados pelo metrô. 


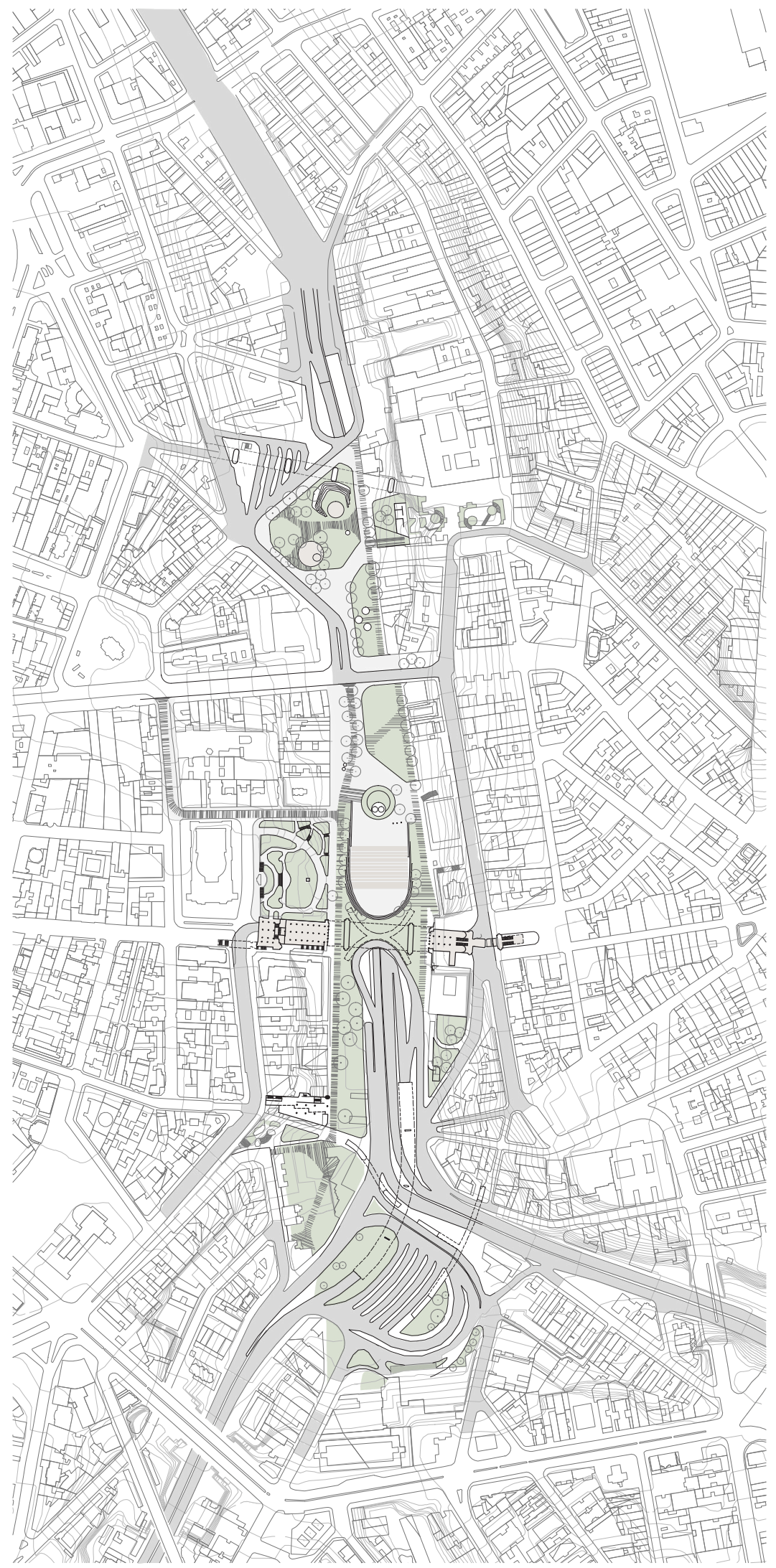

fig.68 Redesenho da propota de

Siegbert Zanettini e Paulo BAstos Acervo do Autor
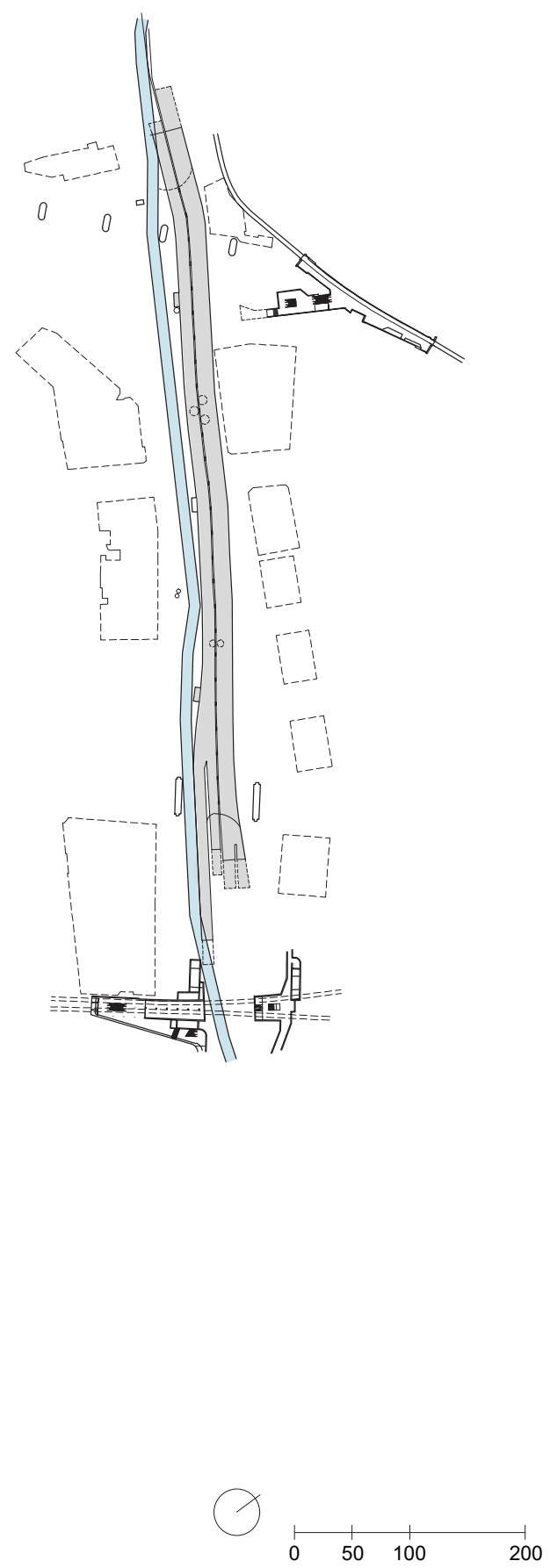


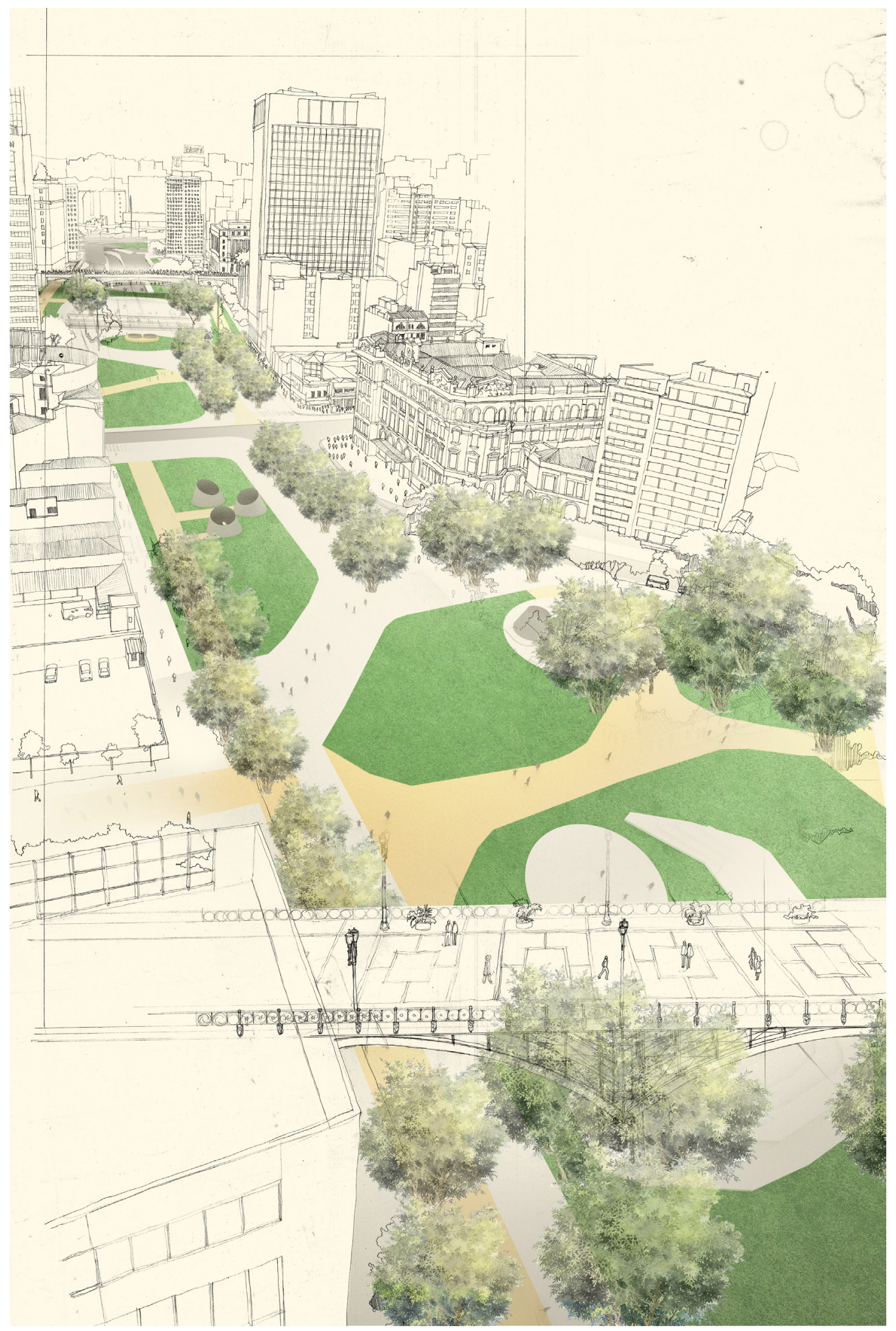




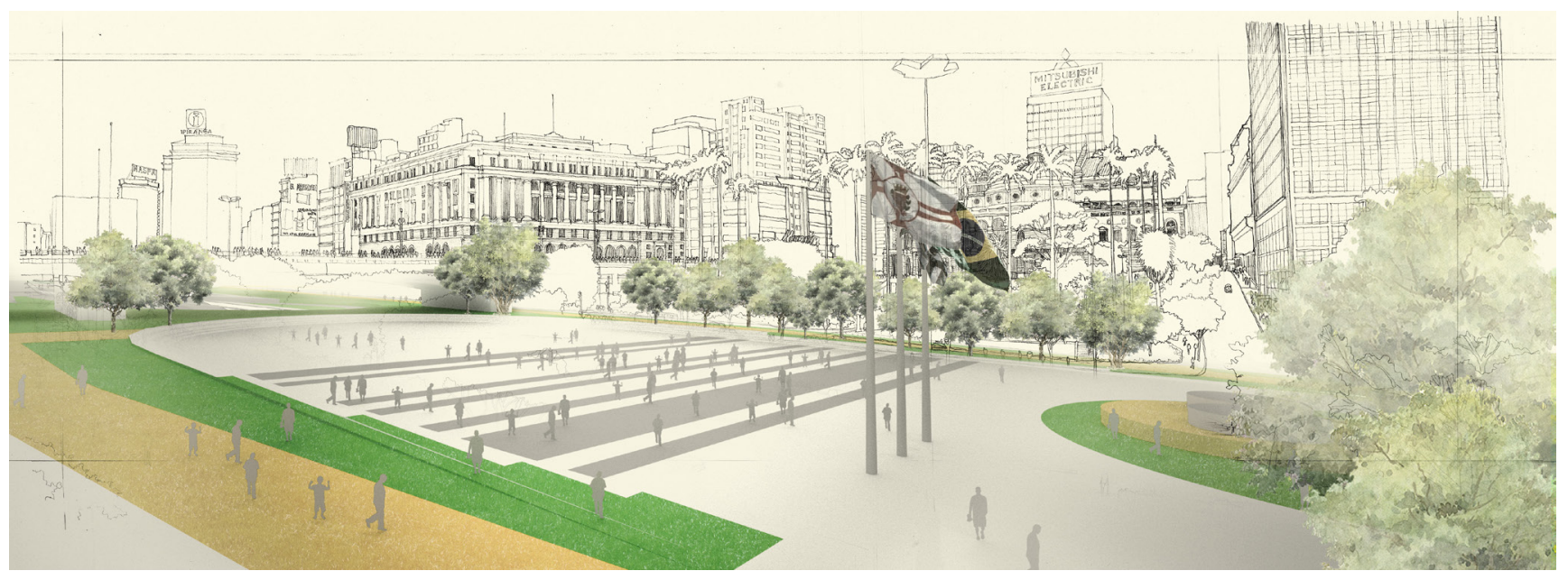

fig.69 Ao lado, foto inserção do projeto de BZ sobre perspectiva à mão de Siegbert Zanettini - Carlos Eduardo Miller e Bhakta Krpa fig.70 A cima, foto inserção do projeto de $\mathrm{BZ}$ sobre perspectiva à mão de Siegbert Zanettini - Carlos Eduardo Miller e Bhakta Krpa 


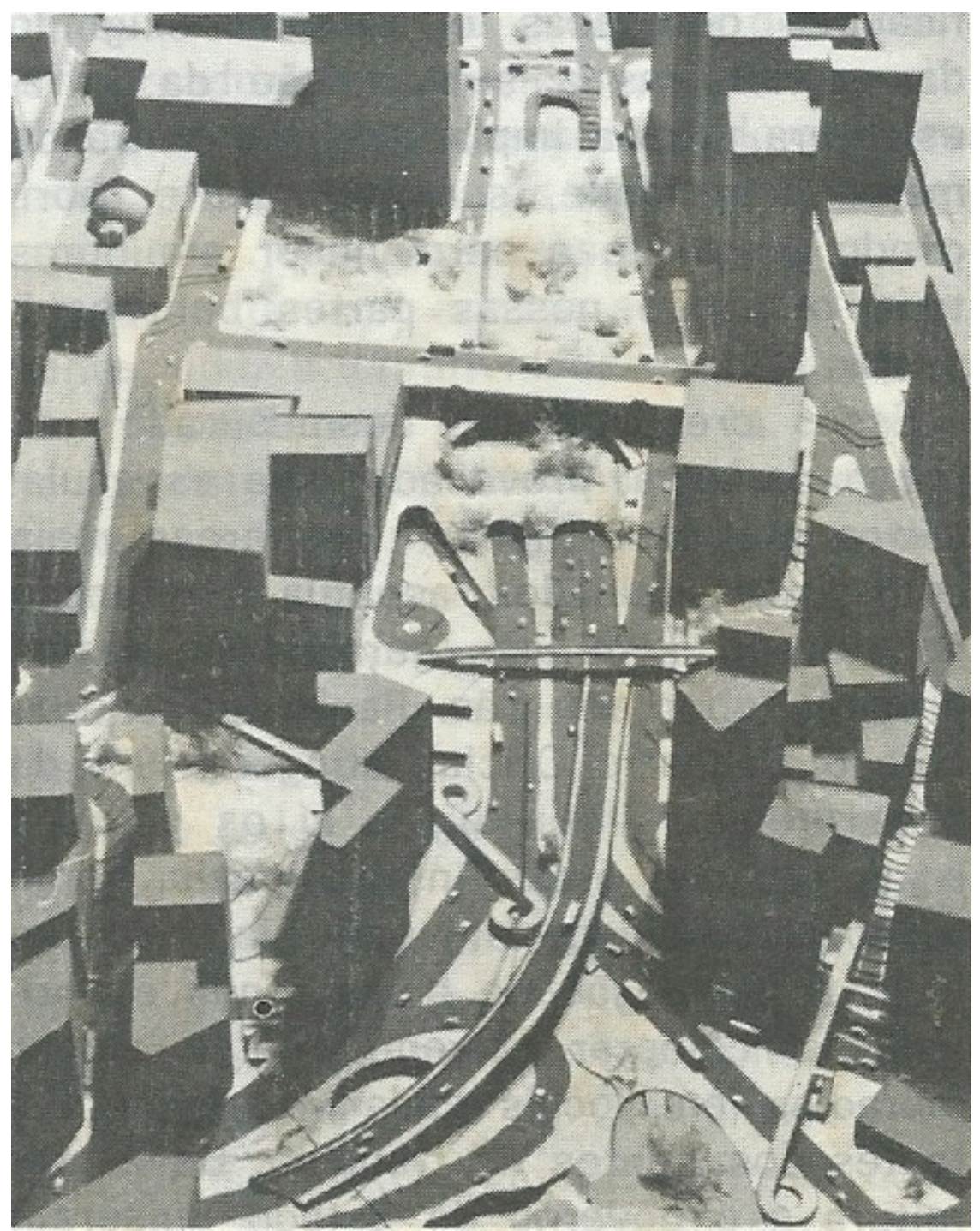

fig.71 Foto da Maquete

do Vale do Anhnaga-

baú, ACSP 1745 p12 


\section{Projeto 82 [2 prêmio]}

Autores:

Elgson Ribeiro Gomes - Engenheiro e Arquiteto (Curitiba - PR)
Colaboradores:

Maria Luiza Gomes - Arquiteta Péricles Varella Gomes - Estagiário Carlos Guilherme Gloor - Estagiário Heitor C. Moreira Filho - Estagiário Orlando V. A. Rodrigues - Estagiário Renato Brandão - Estagiário Ricardo Zig Koch - fotografia

O projeto liderado por Elgson Ribeiro Gomes, graduado em Engenharia Civil pela Universidade Federal do Paraná em 1945 e em Arquitetura e Urbanismo pelo Universidade Presbiteriana Mackenzie em 1958, apresenta como estratégia básica para a resolução do conflito entre pedestres e veículos uma proposta baseada em dois momentos: o primeiro considerando uma intervenção imediata, realizado em fase única e a ser totalmente implantado ainda no ano de 1981, e o segundo a ser realizado ao longo dos próximos anos e contando com quatro etapas de implantação.

Como intervenção imediata Gomes propõem a criação de cinco novas passarelas, sendo duas de caráter provisório, a primeira localizada no cruzamento da Avenida São João e Anhangabaú e a segunda conectando a Praça Pedro Lessa e a estação São Bento, e três de caráter definitivo, sendo duas junto à Praça da Bandeira, uma sobre a Avenida Vinte e Três de Maio e outra sobre a Avenida Nove de Julho, e uma terceira conectando a Rua Formosa à Ladeira Doutor Falcão Filho.

Quanto à intervenção a longo prazo, Gomes propõem que haja a combinação de diferentes estratégias para a resolução do conflito entre pedestres e veículos. No trecho sul do Vale, o arquiteto sugere a manutenção da geometria do sistema viário princi- 

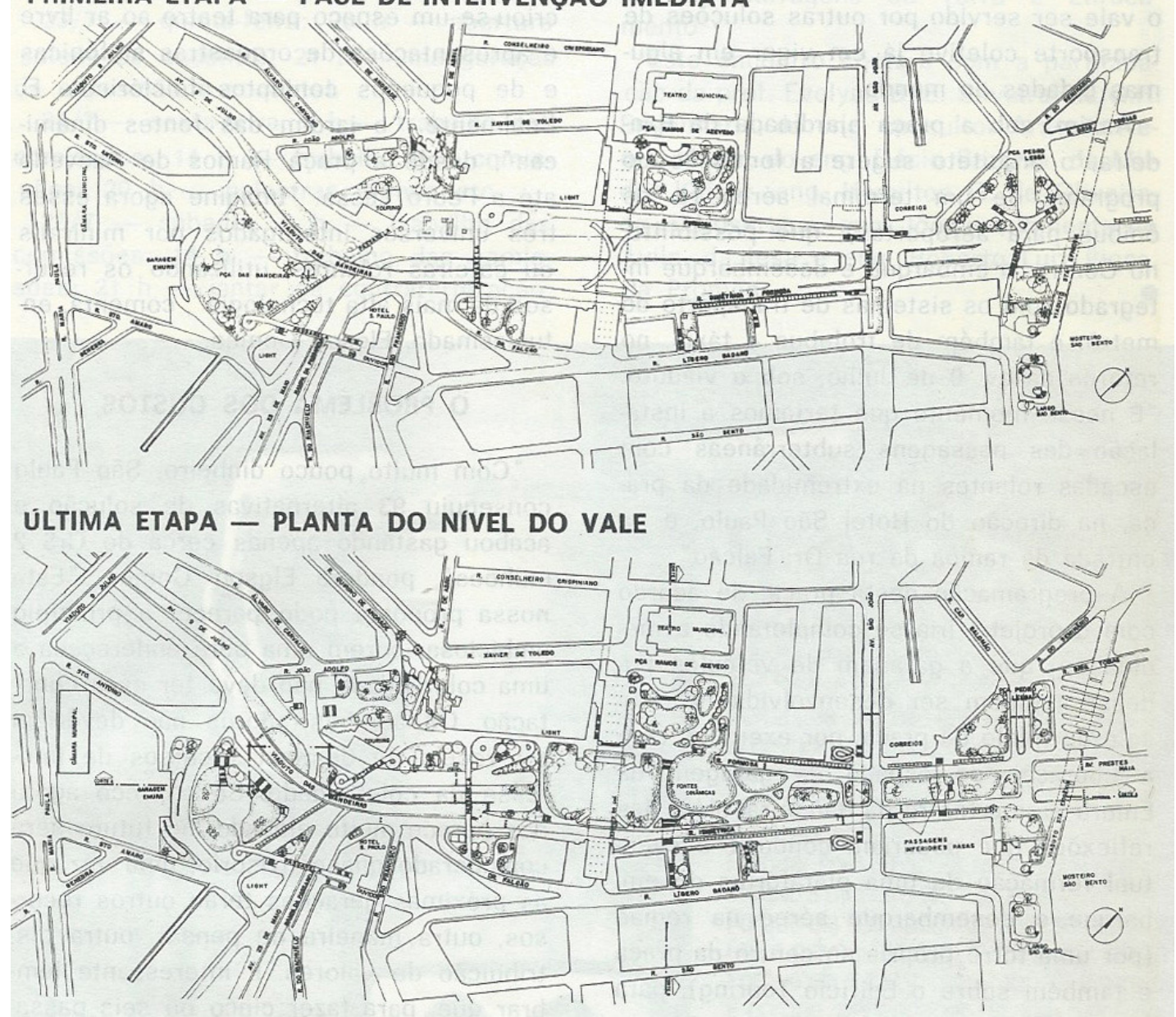

pal (Vinte e Três de Maio e Nove de Julho) e a realização da travessia de pedestres por dois tipos de passagem em nível: o primeiro utilizando-se das passarelas definitivas já criadas na etapa anterior e o segundo por uma grande passagem subterrânea que conectaria o subsolo da Praça da Bandeira à extensão da Ladeira da Memória.

No trecho entre Praça da Bandeira e Praça Ramos de Azevedo o autor sugere que a travessia de pedestres se realize também por dois sistemas distintos: o primeiro utilizando-se da passarela realizada anteriormente na intervenção imediata e a segundo por meio da combinação de uma grande plataforma que se estende desde a margem oeste do Vale, desenvolve-se sobre a Rua Formosa e conecta-se à calçada oposta por meio de duas passagens subterrâneas sob a rua Simétrica (Anhangabaú). 
Já no trecho que se estende entre Praça Ramos e Viaduto Santa Efigênia, Gomes propõem que a travessia de pedestre seja realizada por meio de duas passagens inferiores rasas, uma no eixo da Avenida São João e outra em frente ao edifício do Correio.

Quanto ao tráfego de veículos, Gomes prevê a circulação de automóveis individuais por dois túneis, um no sentido Sul-Norte e outro no sentido Norte-Sul, que se estendem desde as proximidades do Edifício da Light até o Viaduto Santa Efigênia, totalizando aproximadamente 620 metros. Por estes túneis ainda seria possível aos motoristas acessar à Avenida São João no sentido Norte-Oeste diretamente ou no sentido Sul-Oeste por meio de uma rampa se acesso. Por meio de uma rampa criada junto à Praça Pedro Lessa haveria ainda um acesso alternativa para aqueles motoristas que se dirigissem no sentido Oeste-Sul. Para os veículos coletivos e trólebus foram destinadas a circulação pelas ruas Formosa (parcialmente rebaixada) e sua simétrica, onde estariam distribuídos os pontos de parada e os acessos às passagens subterrâneas.

No que diz respeito ao desenho dos espaços livres, Gomes e sua equipe apresentam uma proposta pautada em "restituir, ao Centro de São Paulo, a natureza original e o verde no dia-a-dia do cidadão"25, priorizando assim a criação de grandes áreas ajardinadas, fontes dinâmicas e caminhos sinuosos em toda a extensão do Vale, da praça da Bandeira aos baixios do Viaduto Santa Efigênia. Não há nos desenhos a caracterização de espaços que sugiram alguma atividade especial, apesar de haver no memorial a menção a vontade de criar áreas estar, encontro e manifestações culturais, sobretudo no trecho defronte ao Teatro Municipal.

Na margem leste do Vale, próximo ao edifício do Hotel São Paulo, os autores sugerem a integração dos espaços utilizados como estacionamentos no interior das quadras para a criação de pequenas praças e de um percurso alternativo entre a passarela de acesso à Praça da Bandeira e Rua Dr. Falcão Filho.

Do ponto de vista da sugestão de novos programas, Gomes e sua equipe sugerem a criação de três novos programas, todos eles ligados ao sistema de transporte. Para o trecho sul do vale, $o$ arquiteto sugere a criação de um novo terminal intermodal no subsolo da Praça da Bandeira, onde estariam reunidos um bolsão de estacionamento para veículos individuais, área para lojas e pequenos serviços, uma área para o em-

25 - A Construção São Paulo, número 1745, p. 12 
barque e desembarque de taxis, um "terminal aéreo" para o embarque e desembarque de passageiros dos aeroportos de São Paulo (Congonhas e Campo de Marte) com sistema de ônibus expresso para estes destinos; e um terminal aéreo para o embarque e desembarque de helicópteros, que poderiam aterrissar ou no topo dos prédios vizinhos ou em uma torre própria a ser construída com esta finidade.

No trecho central do Vale, entre Ladeira da Memória e Avenida São João, o autor sugere a criação de um sistema de "monorail" ou esteira rolante capaz de conectar os três "universos" ${ }^{26}$ presentes no interior do Vale - à sul o criado pela Ladeira da Memória - Estação Intermodal, ao centro o universo em torno da Praça Ramos de Azevedo, e ao norte o universo criado pelas fontes dinâmicas.

Por fim, distribuído do extremo sul ao extremo norte do Vale, em consonância com os planos apresentados pela EMURB no edital do concurso, o autor sugere a criação de uma série de plataformas para o embarque e desembarque dos usuários das linhas de trólebus.

No que diz respeito ao disciplinamento e uso do solo e valorização do patrimônio histórico e ambiental, Gomes sugere a adoção de uma normativa orientada no sentido de preservar e revitalizar o patrimônio cultural e de "desafogar"27 a região. Neste sentido o arquiteto propõe que haja a liberação de apenas 50\% das áreas dos terrenos vagos e que os edifícios públicos tombados sejam reciclados e recebam novos programas compatíveis, evitando-se assim a sua desativação e consequente degeneração.

Quanto a desapropriações e demolições, Gomes buscou reduzi-las ao máximo, realizando apenas a desapropriação de dois terrenos junto ao cruzamento da Avenida Anhangabaú com a Avenida São João. Tal desapropriação visaria a construção das rampas de acesso à passagem subterrânea rasa prevista para este trecho.

26 - A Construção São Paulo, número 1745, p.14

27 - A Construção São Paulo, número 1745, p.14 


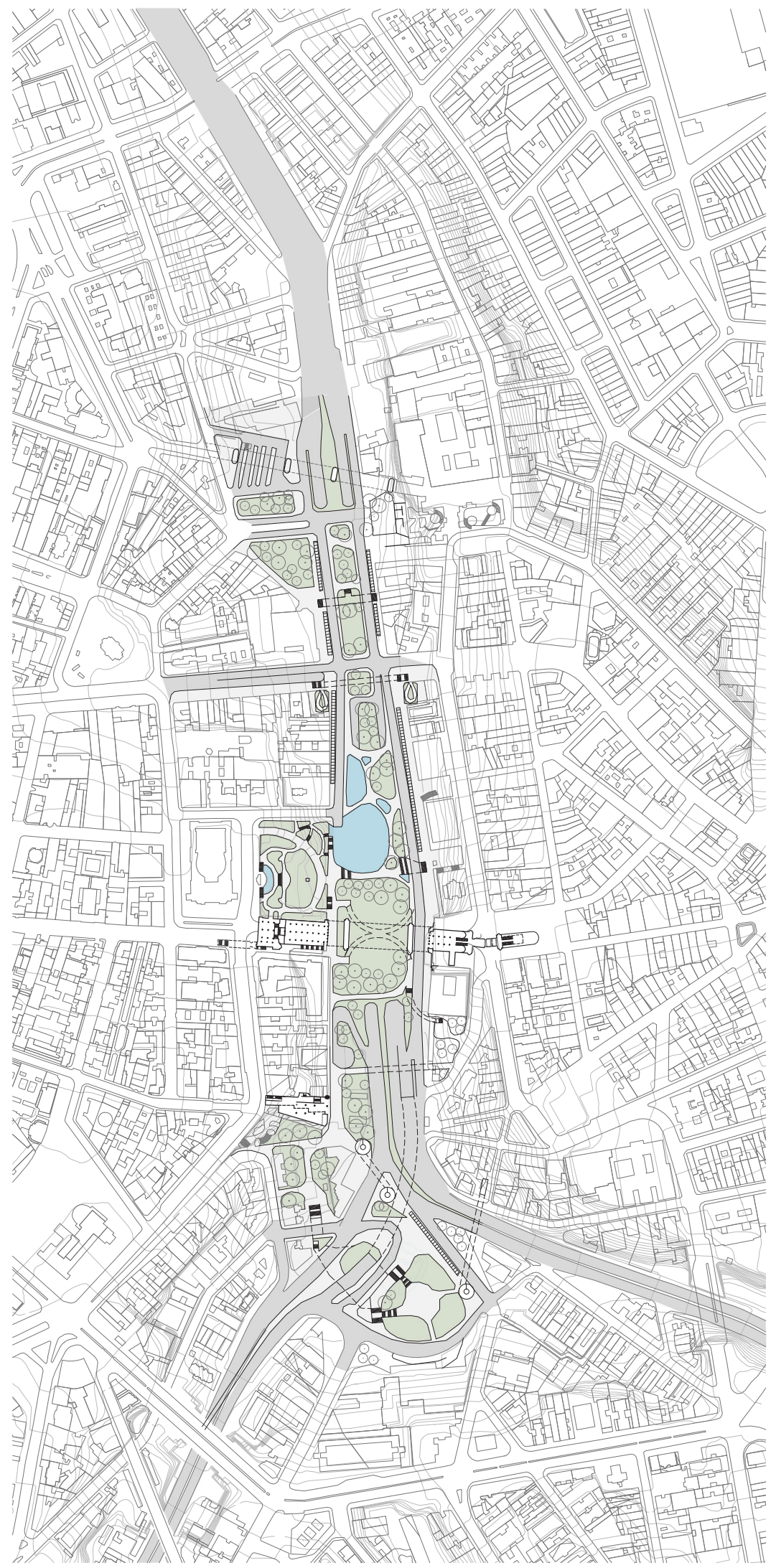

fig.73 Redesenho da propota de Elgson Gomes Acervo do Autor
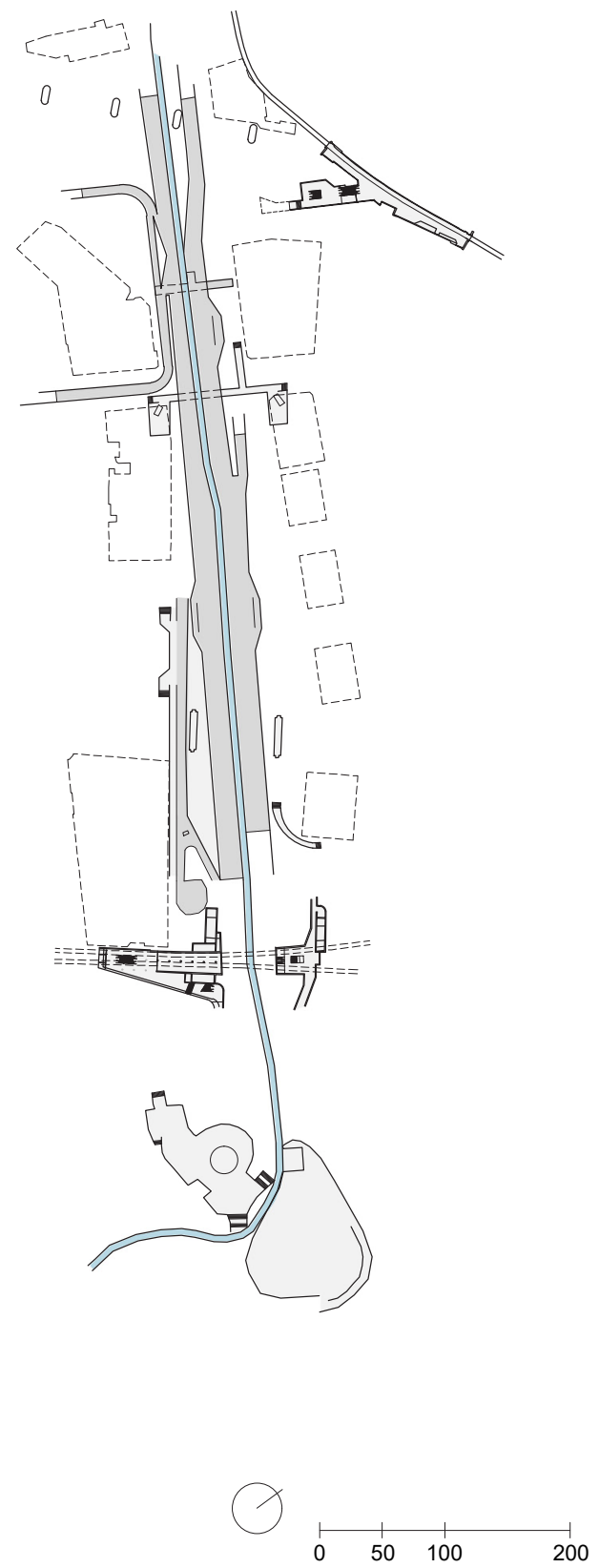


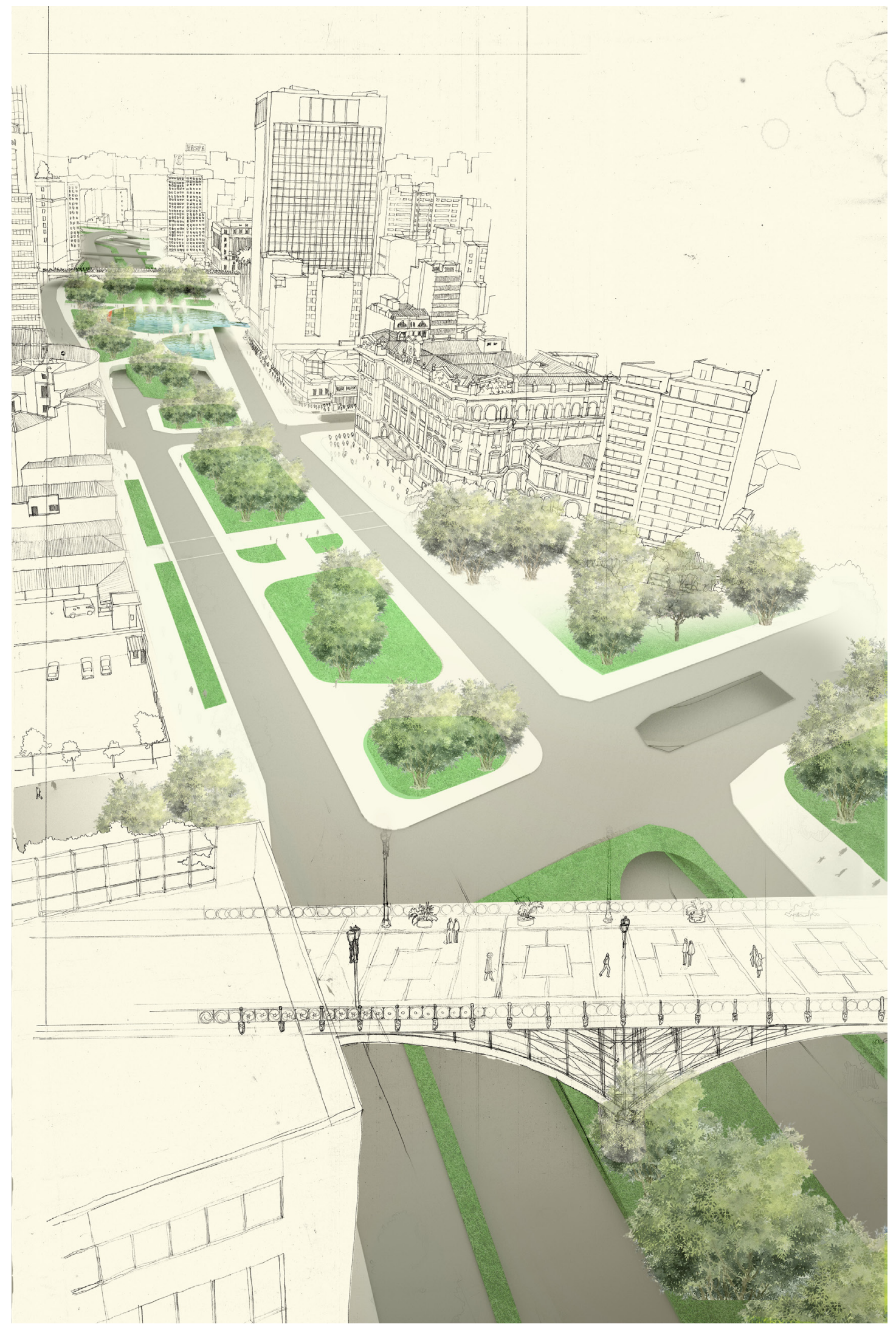




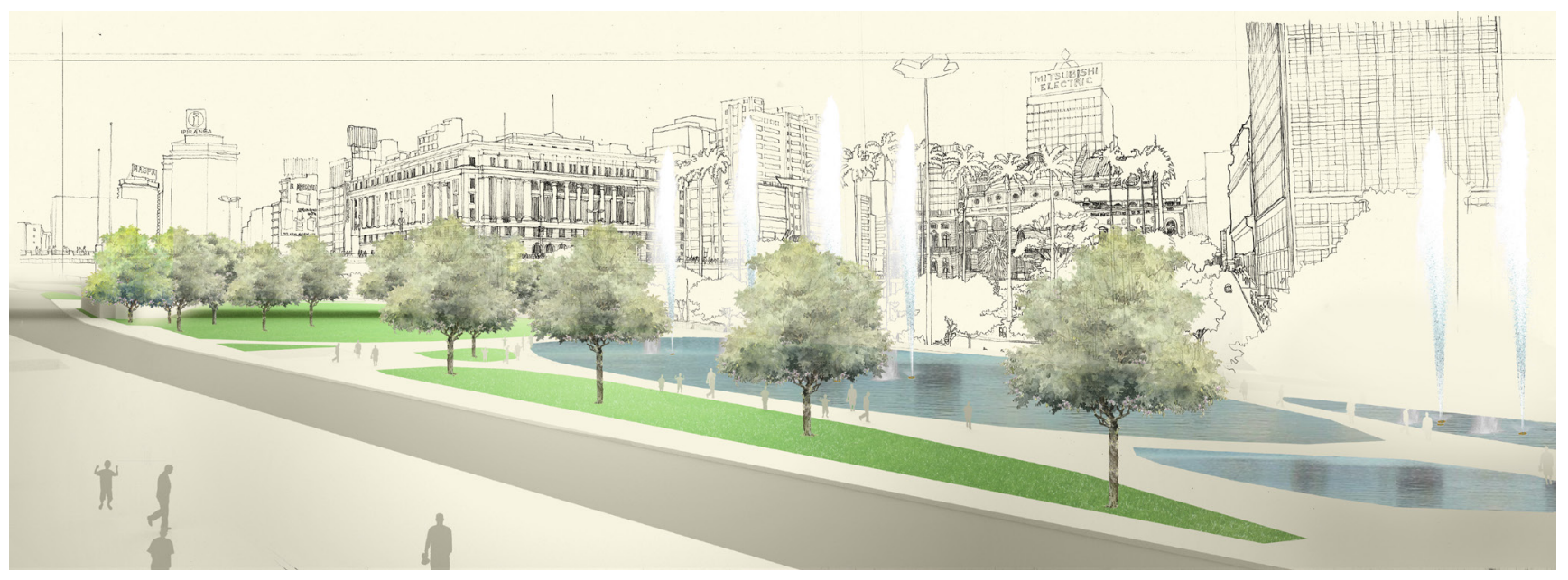

fig.74 Ao lado, foto inserção do projeto de EG sobre perspectiva à mão de Siegbert Zanettini - Carlos Eduardo Miller e Bhakta Krpa fig.75 A cima, foto inserção do projeto de EG sobre perspectiva à mão de Siegbert Zanettini - Carlos Eduardo Miller e Bhakta Krpa 


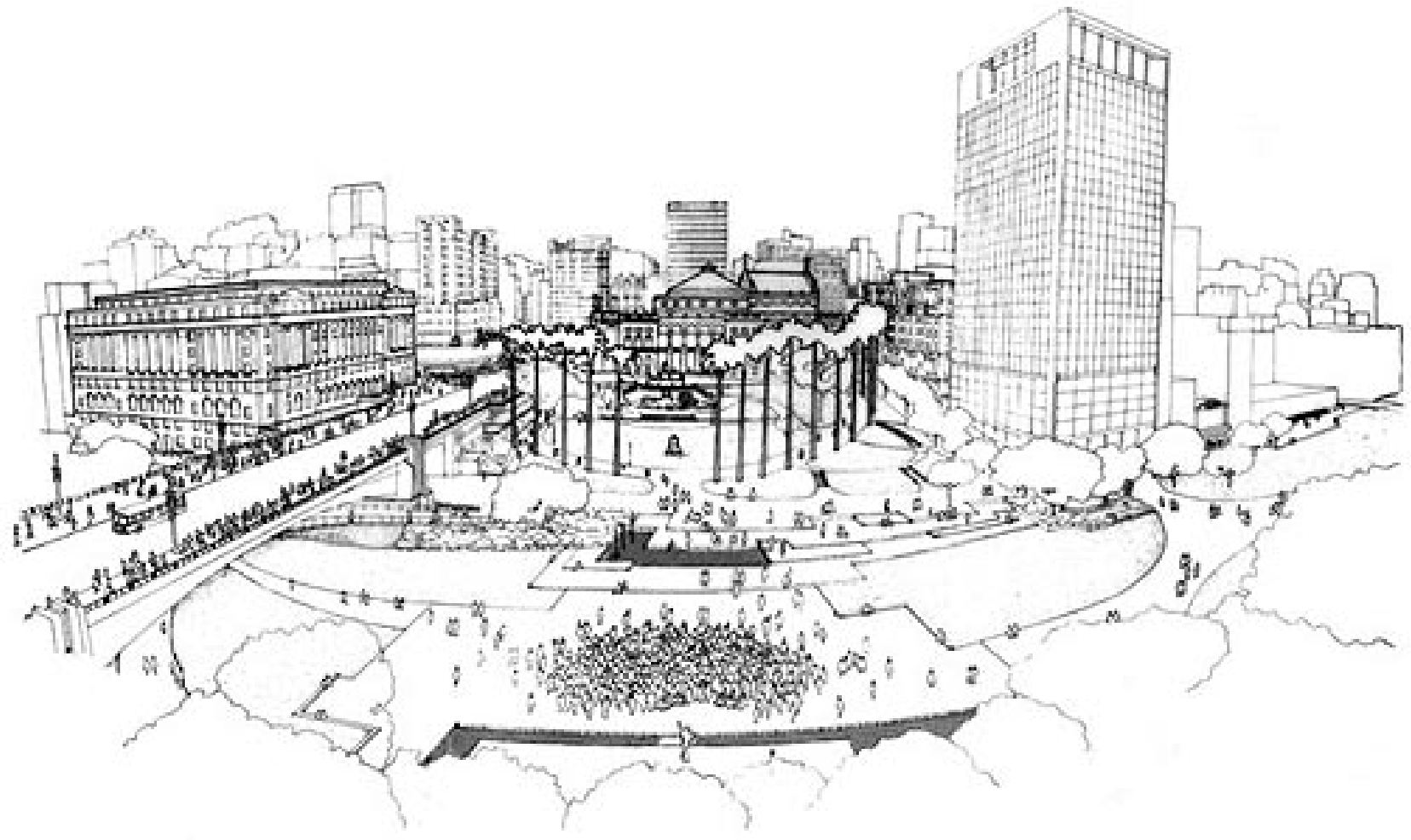

fig.76 Perspectiva do Vale do Anhnagabaú, prancha entregue ao concurso - retirado do site http://www.jorgewilheim.com.br/ legado/Projeto/visualizar/1835 em 04/07/2016 


\section{Projeto 17 [ $1^{\circ}$ prêmio]}

Autores:

Jorge Wilheim - Arquiteto (São Paulo - SP)

Rosa Grena Kliass - Arquiteta (São Paulo - SP)

Jamil José Kfouri - Arquiteto (São Paulo - SP)
Colaboradores:

Carmen Lydia N. R. e Silva - Arquiteta

Jonas Birges - Arquiteto

Marcelo B. Martinez - Arquiteto

Maria Lucinda M. Aguiar - Arquiteta

Michel Todel Gorski - Arquiteto

Mario Franco - Engenheiro Calculista

Carlos Marrei - Engenheiro / Sistema constru-

tivo

Julio Cerqueira Cesar - Engenheiro

Newton Karassawa - Engenheiro / Trasnporte

Francisco Luis B. Costa - Transporte

Jorge Kayano - Engenheiro / Ventilação

Norberto Chamma - Arquiteto / Com. Visual

A proposta da equipe liderada pelos arquitetos Jorge Wilheim, Rosa Kliass e Jamil Kfouri, graduados respectivamente em 1952 pela Faculdade de Arquitetura e Urbanismo Mackenzie e em 1955 e 1972 Faculdade de Arquitetura e Urbanismo da Universidade de São Paulo, apresenta como estratégia básica para resolução do conflito entre pedestres e veículos o rebaixamento da via expressa do Vale do Anhangabaú em seu sentido longitudinal em um trecho de aproximadamente 430 metros e com profundidade entre 8,0 e 10,5m. A esta estratégia, a qual veremos irá se repetir em outros trabalhos, chamaremos de Túnel-Plataforma.

A criação destes túneis traria ao Vale do Anhangabaú, segundo os autores, dois benefícios. O primeiro seria o de permitir o tráfego ininterrupto tanto para os aproximadamente doze mil veículos individuais e coletivos que cruzavam o Vale no sentido Norte-Sul-Norte, quanto para os quase um milhão de pedestres que o atravessavam diariamente; o segundo seria o de desvincular os efeitos negativos que o grande fluxo de veículos traziam para o ambiente do Vale, como a poluição do ar e sonora, os atropelamentos, etc.

Em complemento ao sistema Túnel-Plataforma, os autores propunham ainda mais 

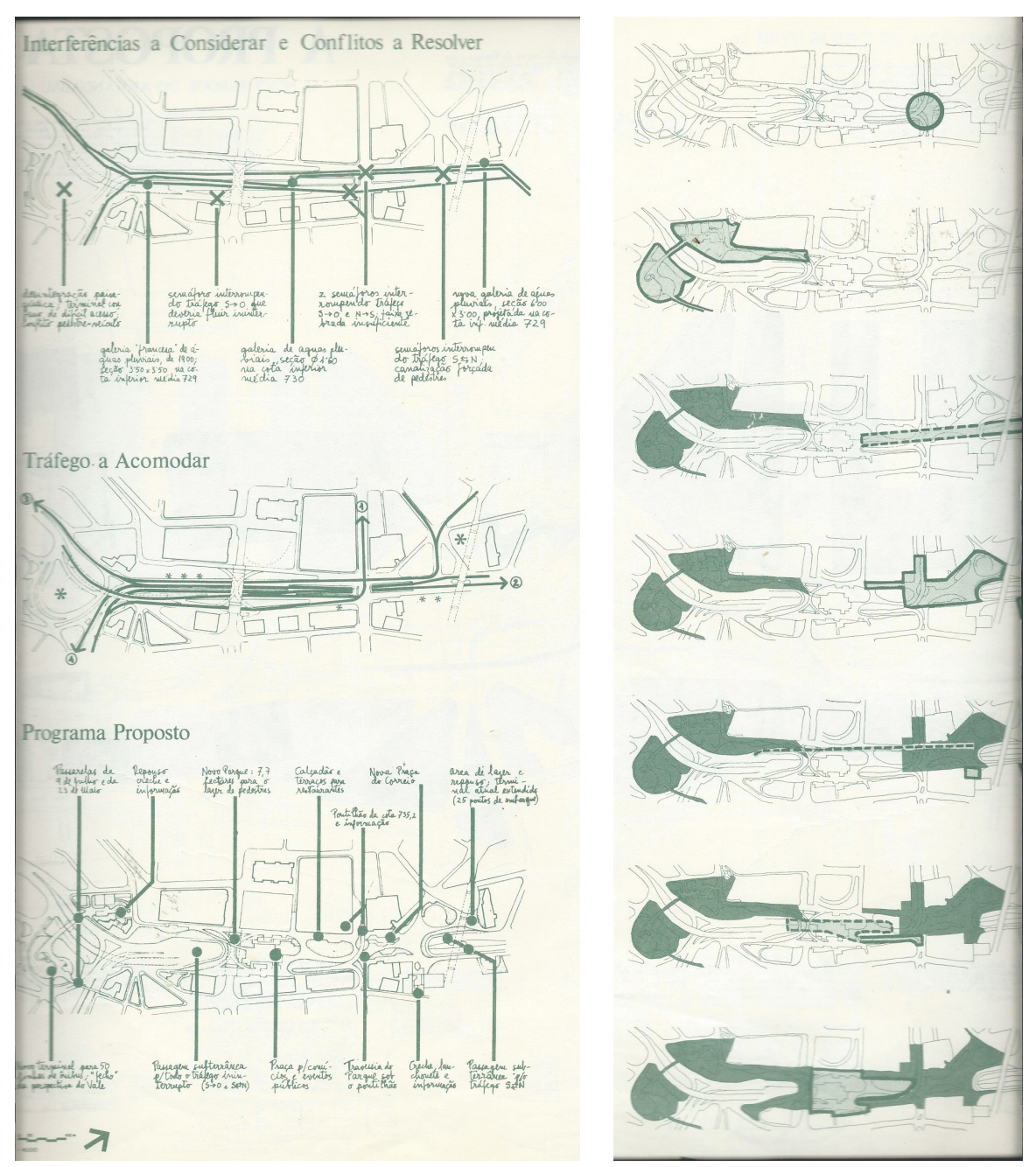

duas intervenções no sistema viário da região: ao sul do Vale, junto à Praça da Bandeira, os autores propunham a criação de duas passarelas que, conectadas entre si pelo terminal de ônibus desta praça, permitiriam a ligação direta entre a região da Memória e da Rua do Ouvidor. Com estas passarelas os autores ainda tencionavam criar dois pórticos de entrada para o Vale, um sobre a Avenida Nove de Julho e outro sobre a Avenida Vinte e Três de Maio; e junto a Avenida São João WKK propunham a realização de um pontilhão curvo que possibilitaria a conversão tanto à esquerda no sentido Sul-Oeste quanto a direita no sentido Sul-Leste.

Do ponto de vista do desenho dos espaços livres Wilheim, Kliass e Kfouri estruturam sua proposta a partir das preexistências da região. Conforme argumenta Kliass "nós 
não tínhamos nenhuma ideia pré-concebida, mas esta começou a ser desenvolvida à medida que analisávamos a situação verdadeira do Vale do Anhangabaú”28

Iniciando pelo trecho sul do vale, partindo das precárias condições de acesso e conforto os autores do Terminal de ônibus da Praça da Bandeira, os autores propõem a realização de uma grande cobertura ajardinada no nível $+739,0$, realizando assim o acolhimento dos usuários da estação, a conexão em nível com as passarelas sobre as Avenidas Nove de Julho e Vinte e Três de Maio e prolongando visual dos terraços ajardinados da Câmara de Vereadores. Para Wilheim a criação desta cobertura ainda permitiria o fechamento da perspectiva sul do Vale. ${ }^{29}$

Um pouco mais ao norte, na região do Largo da Memória, os autores preveem a integração desta área com os terraços de acesso da à estação Anhangabaú do Metrô. Estendendo-se da Ladeira da Memória até a Avenida Nove de Julho e aproveitando alguns terrenos desapropriados e demolidos pelo Metrô os autores propõem a criação de uma pequena praça de miolo de quadra, a qual abrigaria área de estar, creche e serviços para trabalhadores.

Passando ao trecho defronte à Praça Ramos de Azevedo, Wilheim, Kliass e Kfouri sugerem a criação de uma "grande praça" ${ }^{30}$, destinada a comícios, espetáculos populares, concertos e festivais de dança. Para tanto os autores buscaram respeitar os alinhamentos pré-determinados pela Praça Ramos de Azevedo, situando o ponto central da nova tribuna a ser construída em seu eixo de simetria. A esta tribuna destacamos a figura humana desenhada em uma das perspectivas apresentadas pela equipe ao Concurso que, segundo Wilheim ${ }^{31}$, representava a cantora folk norte-americana Joan Baez, impedida de se apresentar pelo regime militar no TUCA em maio de 1981, um mês antes da entrega do concurso.

Para a acomodação do público os autores previram a realização de múltiplos patamares e espelhos d'água, que além de criar palcos alternativos trariam a conformação de pequenos recantos para eventos de menor porte. Para os eventos de massa, imaginavam os autores, que o jardim do teatro poderia ser utilizado como anfiteatro natural e prolongamento da praça.

28 - A construção São Paulo, número 1741, p06

29 - A construção São Paulo, número 1741, p07

30 - Ibidem

31 - WILHEIM, Jorge. A Obra Pública de Jorge Wilheim - São Paulo. Editora DBA, 2003, p. 158 
Ao fundo da tribuna os autores propunham a criação de um maciço de árvores utilizando espécies de copa larga. Com isto os autores buscavam criar tanto um pano de fundo para a tribuna quanto o uma área de sombra para o calçadão proposto entre esta e os edifícios existentes. Para este calçadão, que seria acessado tanto pelo fundo do Vale quanto pelas escadarias da Rua Libero Badaró, estavam previstos incentivos para a abertura de cafés e pequenos comércios. Estratégia semelhante à esta adotada para o fundo da tribuna foi proposta para o trecho defronte ao Edifício CBI Esplanada, com o acréscimo de uma área destinada a implantação de um posto de serviço de suporte ao trabalhador.

Para o eixo da Avenida São João os arquitetos previam o alargamento das calçadas e a construção de escadarias que permitiriam a transposição do pontilhão pelos pedestres. Um pouco mais adiante, os autores propõem a criação de duas pequenas praças de estar, uma sem arborização de porte e voltada para a entrada do Edifício Central do Correio e outra mais arborizada voltada para os edifícios do entorno do Vale. Entre estas praças haveria uma passagem ladeada por jardins e espelhos d'água.

Chegando à Praça Pedro Lessa Wilheim, Kliass e Kfouri sugerem a criação de uma área destinada a encontros, lazer, repouso e recreação infantil. Para tanto os autores se valem das árvores existentes para a realização de um denso bosque e complementam a área com disposição de grandes bancos de alvenaria, curvos e convexos, e de equipamentos como playgrounds, bancos isolados, mesas para jogos, etc. Na porção oeste da Praça, junto a Rua Brigadeiro Tobias, os autores resguardam uma área para a parada de linhas de ônibus previstas pelo plano de integração com trólebus.

Por fim, nas proximidades do Viaduto Santa Efigênia, os arquitetos preveem a criação de uma pequena praça de acomodação para os usuários da estação São Bento do Metrô. Nesta praça, a semelhança da praça criada junto à Ladeira da Memória e Estação Anhangabaú são distribuídos alguns serviços públicos, tais como creche, posto de informação, etc.

Como complemento ao desenho proposto, Wilheim, Kliass e Kfouri sugerem a criação de alguns novos programas para o espaço do Vale, que seriam distribuídos ao longo do Vale em três núcleos - um próximo a Ladeira da Memória, outro no térreo do edifício a ser construído na esquina da Avenida São João e um terceiro junto ao 


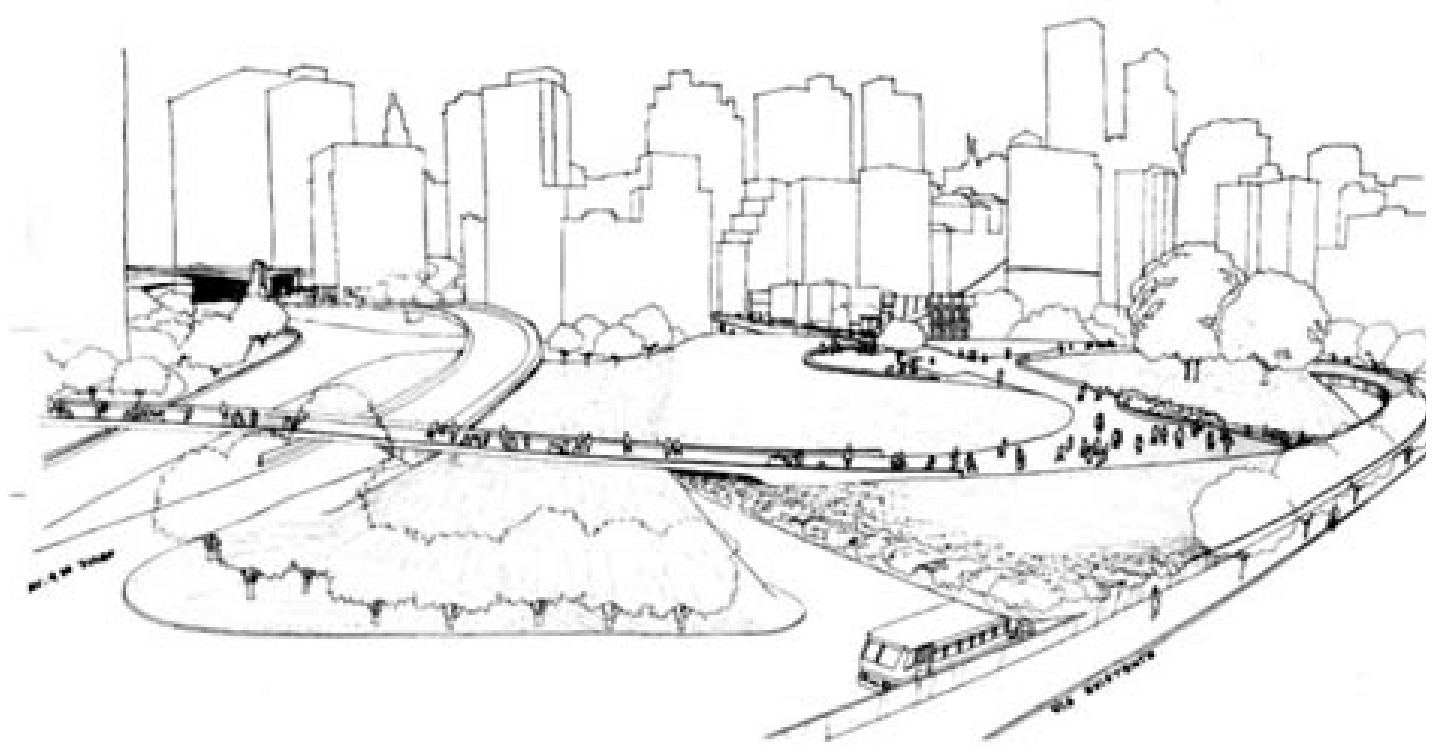

fig.78 Perspectiva do Vale do Anhnagabaú e planta de priorização, prancha entregue ao concurso - retirado do site http://www. jorgewilheim.com. br/legado/Projeto/ visualizar/1835 em 04/07/2016

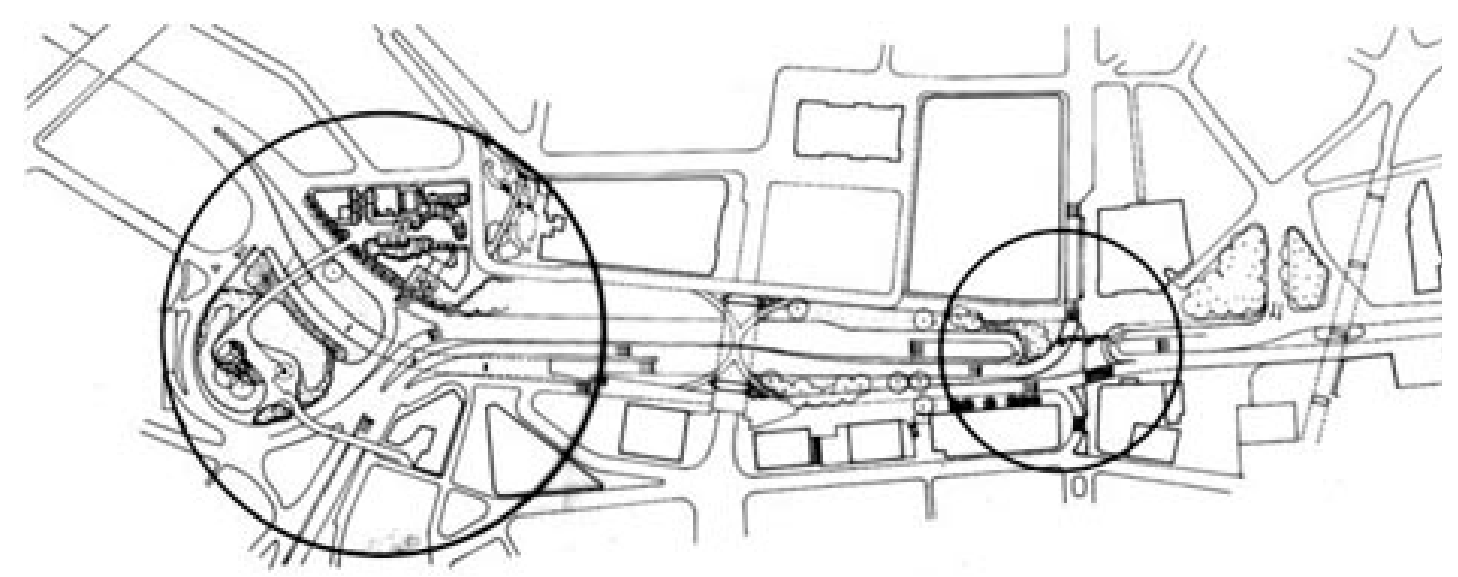

acesso inferior da Estação São Bento. Nestes núcleos haveriam creches, lanchonetes, sanitários públicos, centro de informação computadorizado, postos para retirada de documentos e atendimento ao trabalhador.

Do ponto de vista programático, os autores ainda preveem a construção de dois novos terminais de ônibus, um na Praça da Bandeira dimensionado para a cinquenta linhas e outro na Praça Pedro Lessa, dimensionado para vinte cinco linhas.

Quanto a distribuição perimetral destes novos programas em relação ao espaço do Vale, vale destacar o depoimento concedido por Rosa Kliass à TV PUC-SP em maio de 2014 no qual ela diz: 
"Jorge e eu trabalhávamos cada um em seu escritório, desenvolvíamos nossos desenhos separadamente e então nos encontrávamos para discutir as ideias e tirar dali uma posição final até aquele ponto. Sempre que nos encontrávamos a equipe do Jorge trazia como proposta alguma "construnçãozinha" no meio do espaço do Vale e nós o convencíamos a tirar. Até que um dia o Jorge disse - "Rosa, o que você quer fazer é um parque?” - ao que e respondi - sim, um Parque!

Dali em diante não tivemos mais construções em meio ao espaço livre do Vale, a não ser no cruzamento da Avenida São João (baixio do pontilhão curvo), onde, de forma totalmente camuflada, imaginávamos criar um café e banheiros públicos"

Do ponto de vista legislativo vale destacar que a maior parte dos novos programas criados não nasceriam de ações diretas do Estado, mas sim da ação de empreendedores e comerciantes da região. Para tanto Wilheim, Kliass e Kfouri previam a criação de legislação específica a fim de incentivar a abertura de novos comércios e serviços no térreo dos edifícios limítrofes ao Vale.

Outro ponto que deveria ser atendido por meio de nova legislação seria a limitação da altura das futuras edificações a serem construídas no lote de esquina da Avenida São João com Anhangabaú defronte ao Prédio do Correio, garantindo-se assim a visão deste edifício tombado pelo patrimônio histórico.

No que diz a conservação e valorização do patrimônio histórico e ambiental, os arquitetos preveem a recuperação da Ladeira da Memória, dos edifícios da ex-Light, do Teatro Municipal, do Conservatório Musical, do Edifício do Correio, dos viadutos do Chá e Santa Efigênia e ainda a manutenção de todas as árvores existentes no Vale e na Praça Pedro Lessa. 


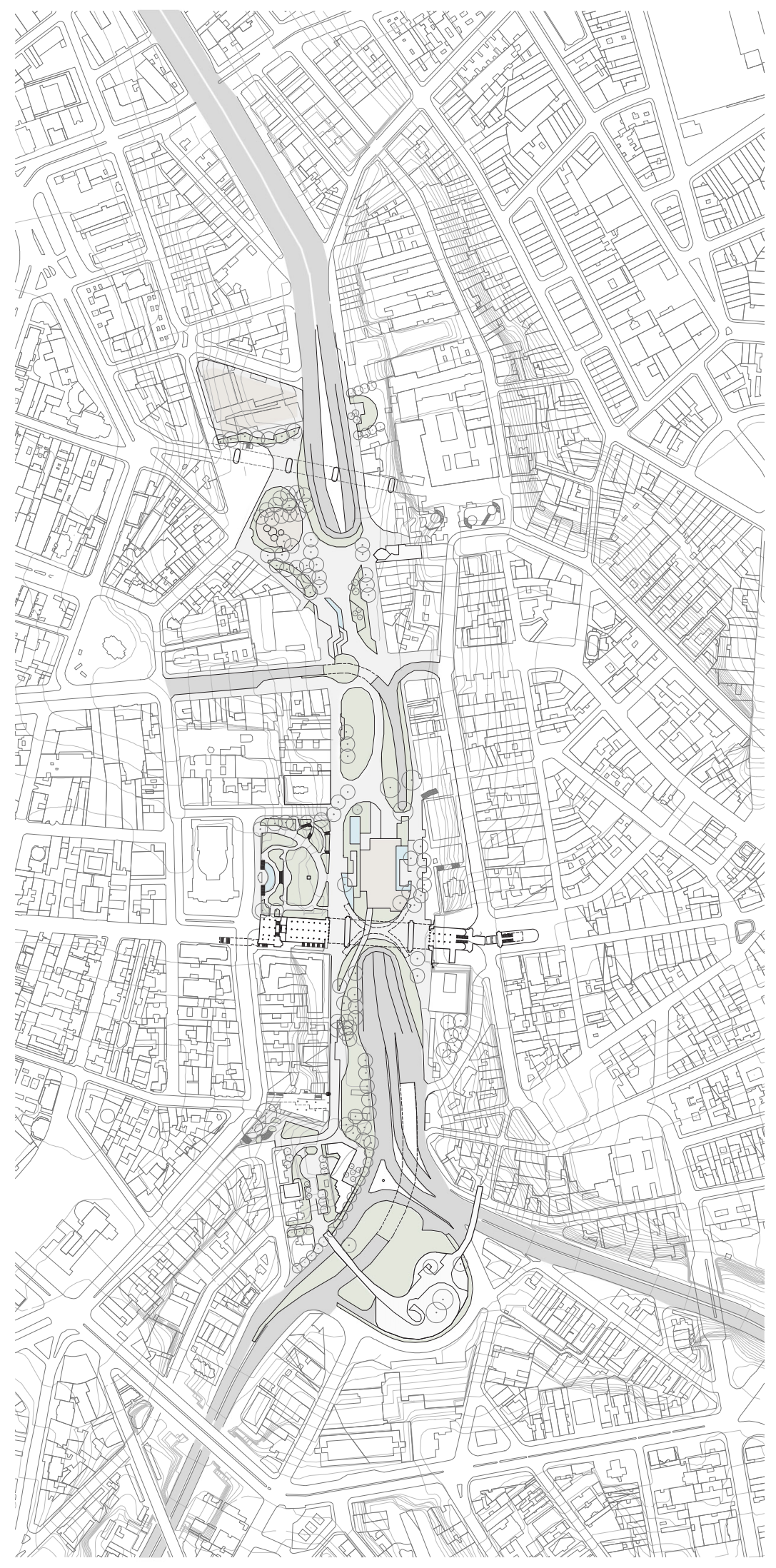

fig.79 Redesenho da propota de Jorge Wilheim, Rosa Kliass e Jamil Kfouri - Acervo do Autor
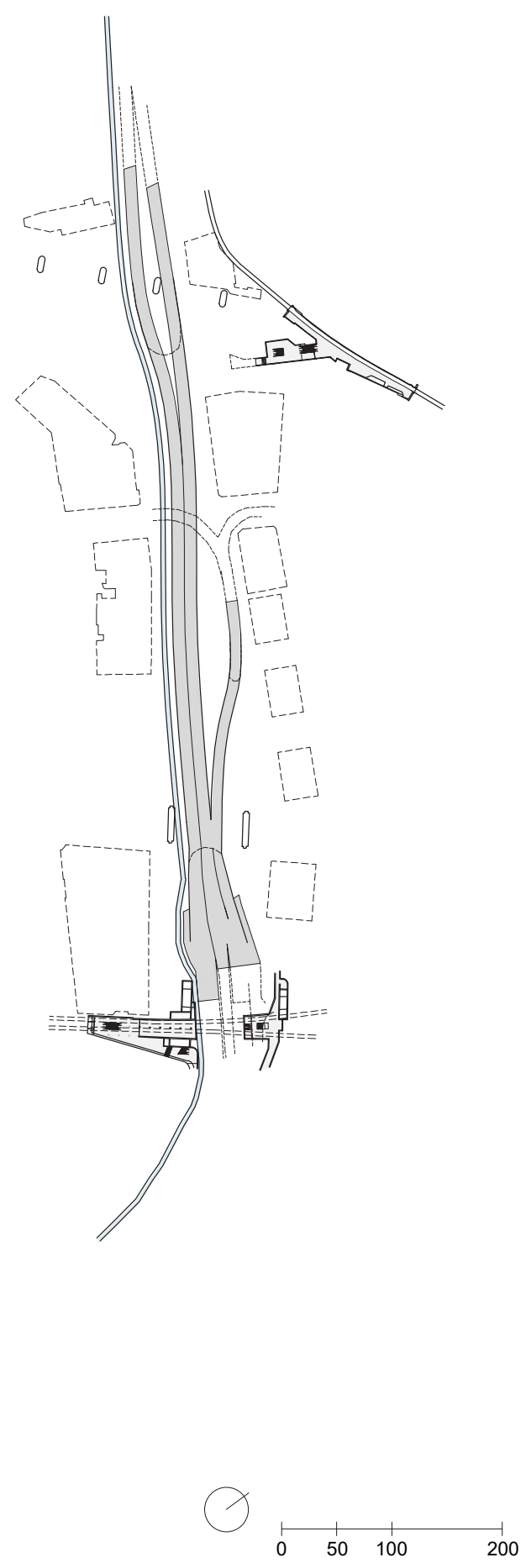


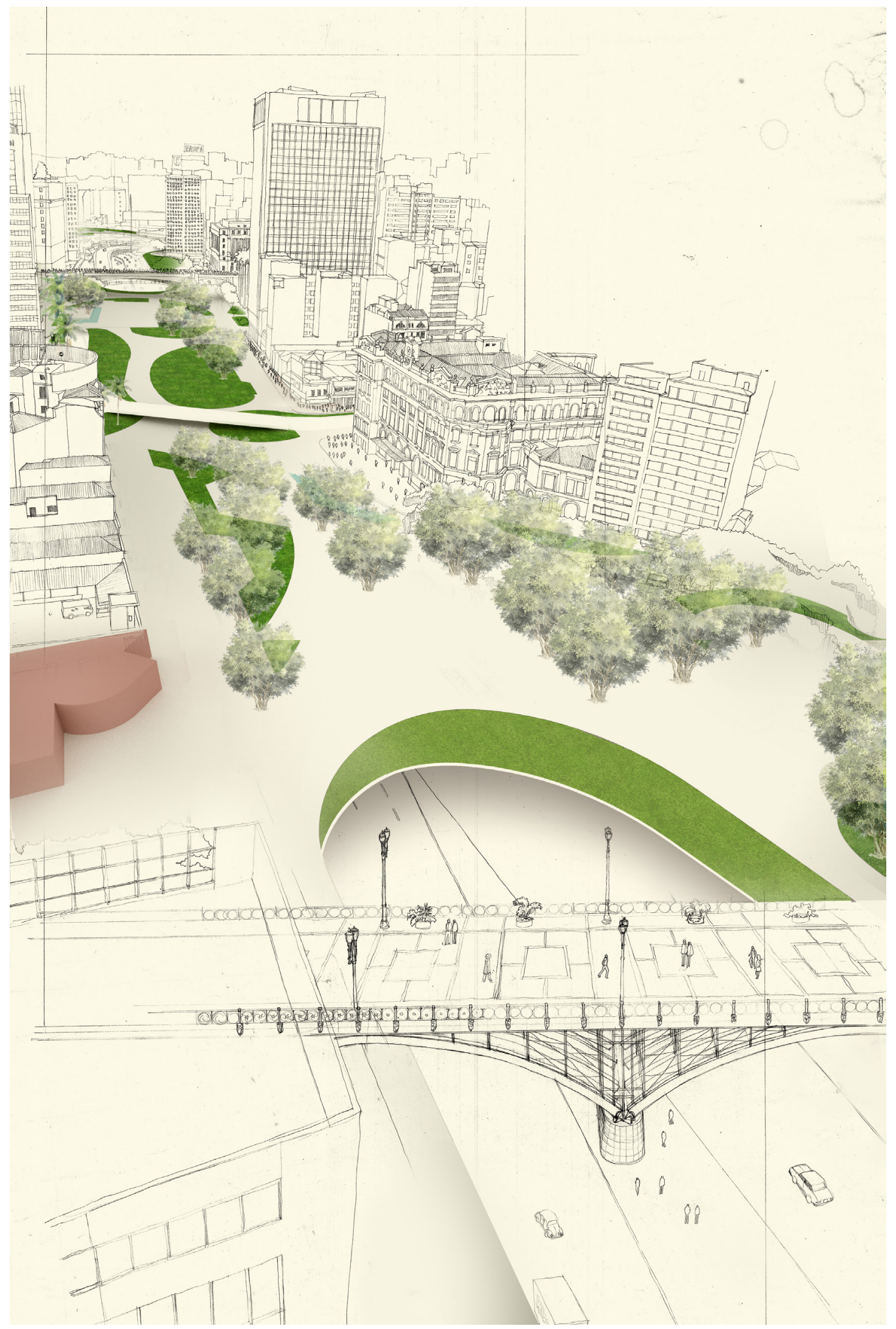




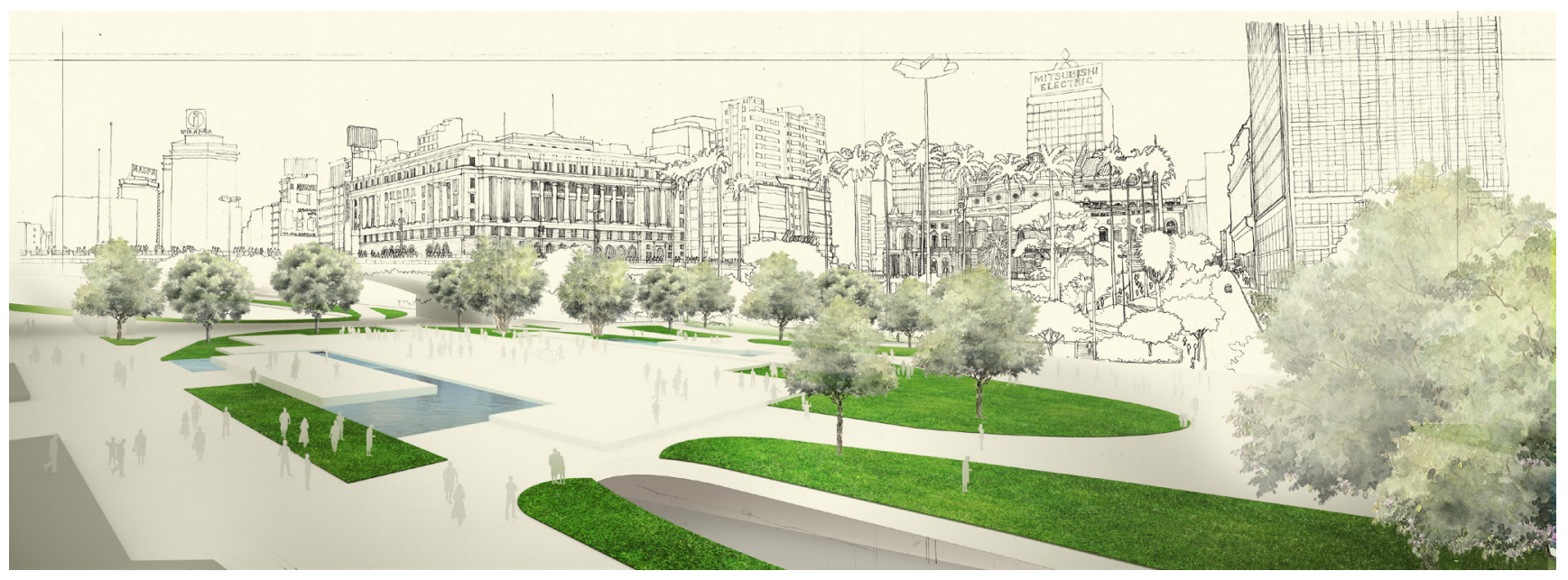

fig.80 Ao lado, foto inserção do projeto de WKK sobre perspectiva à mão de Siegbert Zanettini - Carlos Eduardo Miller e Bhakta Krpa fig.81 A cima, foto inserção do projeto de WKK sobre perspectiva à mão de Siegbert Zanettini - Carlos Eduardo Miller e Bhakta Krpa 
Reurbanização do Vale do Anhangabaú: propostas para recriação de uma paisagem 


\section{A Implantação}

Encerrado o concurso a proposta vencedora de Wilheim, Kliass e Kfouri passou por um longo período de desenvolvimento e implementação entre os anos de 1982, data da contratação efetiva da equipe, e 1991, ano de conclusão das obras.

Neste período notamos que o primeiro desafio enfrentado pela equipe se deu no plano administrativo, uma vez que a sagração do contrato para o desenvolvimento do Plano diretor e Projeto Executivo não ocorreu de forma imediata conforme previsto no edital. Conforme podemos ver na carta enviada em 13/08/1981 por Jorge Wilheim à Otavio Speranzini, presidente da EMURB à época, dois meses após o anuncio do resultado do concurso os arquitetos ainda não haviam tido nenhuma garantia acerca de sua contratação:

São Paulo, 13 de agosto de 1981

Ref:: Anhangabaú

Exmo. Sr. Presidente:

Desejo, antes de mais nada, agradecer pela cortesia e eficiência com que temos sido atendidos, informalmente, pela diretoria de Planejamento da EMURB e pelos técnicos alocados para o tema em epígrafe, no sentido de antecipar informações que permitam deslanchar tarefas contratuais futurais, com maior rapidez e para mútua satisfação.

Permito-me, contudo, assinalar, não ter sido ainda firmado o "Protocolo de Intenções" indicado na cláusula 14.1 do Edital do Concurso, ato este que, 
segundo este Edital, deveria ter sido realizado por ocasião da declaração do resultado $(10 / 06 / 1981)$

Tendo decorrido dois meses do dia dessa declaração, apesar de informalmente ter tomado conhecimento dalguns passos já tomados pela EMURB no sentido de dar prosseguimento ao previsto por dito Edital, venho à sua presença indagar quando será firmado o mencionado Protocolo e/ou Contrato mencionado na cláusula 14.1, para o qual já forneci em 19/07/1981 proposta e minutas.

Grato por sua atenção à presente, subscrevo-me Jorge Wilheim

Alguns dias depois, em 17/08/1981, Wilheim escreve ao arquiteto Cesar Bergstrom Lourenço, Presidente do IAB, alertando-o sobre o fato e ainda sobre um possível remanejamento de verbas dentro da EMURB

São Paulo, 17 de agosto de 1981

Ref:: Concurso Anhnagabaú

Prezado Colega:

Tendo sido o I.A.B o organizador do bem-sucedido concurso em epígrafe, cumpre-me informa-lo que:

a) a EMURB não forneceu, quando da declaração do resultado (10/06/1981), o "protocolo de intenções" de contratação do projeto indicado vencedor (cláusula 14.1 do edital);

b) até a presente data, 67 dias após a declaração, não recebemos a mencionada carta, nem foi ainda assinado contrato, apesar de termos fornecido à EMURB, em 1\%07/1981, a minuta de contrato, cronogramas e demais informações para tal fim; 
c) há fortes indícios de que a EMURB pretende solicitar ao Sr. Prefeito a utilização do valor de 400mil ORTN, mencionadas no edital como disponíveis para as primeiras etapas de implantação, para uma série de intervenções no Centro, possivelmente oportunas, mas que levam sensível redução da primeira etapa proposta pelo projeto vencedor do Concurso.

A fim de não desmoralizar o Concurso que até agora teve a melhor das repercussões, creio ser conveniente um contato do I.A.B, talvez com o próprio Sr. Prefeito, a fim da iniciativa resultar em benefício real para a população, isto é, em projeto e obra concluída.

Agradecendo pela atenção dada a esta, subscrevo-me

Jorge Wilheim

\begin{abstract}
Atendendo ao pedido de Wilheim, uma semana após o recebimento da carta a cima transcrita, o IAB entraria em contato com o prefeito Reynaldo de Barros para buscar um outro desfecho para o impasse.
\end{abstract}

São Paulo, 26 de agosto de 1.981

Senhor Prefeito:

O Instituto de Arquitetos do Brasil - Departamento de São Paulo vem por meio desta solicitar de V. Excia. Medidas que viabilizem a concretização final do Concurso do Anhangabaú que persiste até a presente data, ainda em pendência.

Tal Concurso promovido pela Prefeitura de São Paulo, teve a melhor repercussão pública no sentido do envolvimento de toda a comunidade, em particular da categoria profissional dos arquitetos que nacionalmente se mobilizou para a elaboração de projetos propostos para a cidade de São Paulo.

Hoje passados dois meses da data da abertura dos resultados do Concurso 
ainda restam pendências quanto a contratação do projeto vencedor que até o momento não se efetivou.

Informamos que não foi cumprido um dos itens do edital especificamente o item 9, que deixa clara a obrigatoriedade da assinatura do contrato para elaboração do projeto ainda a assinatura de um protocolo de Intenções que deveria ter sido assinado na data da abertura do resultado do Concurso.

Apesar de solicitarmos esclarecimentos em relação a estas questões junto à EMURB, em ofício de 25/06/1981 até hoje não obtivemos resposta.

Solicitamos de V. Excia. Atenção especial para que tais pendências sejam sanadas e seja garantida a integra do projeto vencedor desta forma coroando de êxito o Concurso realizado.

Acreditando contribuir para evitar as repercussões negativas que a persistência de tais fatos venham gerar, subscrevemo-nos

Arq. Cesar G. Bergstrom Lourenço

Contudo, apesar da apelação feita por Bergstrom, a resposta da prefeitura só viria dois meses depois e ainda de forma parcial, conforme podemos ver na carta enviada por Wilheim ao IAB em 28/10/1981

São Paulo, 28 de outubro de 1981

Ref:: Anhangabaú

Prezado Colega:

Em atenção ao papel desempenhado pelo IAB na organização do Concurso para Reurbanização do Vale do Anhangabaú, assim como nas decorrências vinculadas aos termos do Edital, sinto-me na obrigação de informá-los que o primeiro contrato entre EMURB e os vencedores do concurso deverá ser assinado $5^{a}$ feira, dia 29/10/1981. 
O contrato a ser assinado terá por objeto o projeto executivo das duas primeiras fases de implantação (Praça da Bandeira e obras provisórias da esquina com avenida São João). A rigor, o edital previa igualmente a contratação de um Plano Diretor, certamente necessário. Por isso recusamo-nos inicialmente em ser contratados apenas para parte do previsto pelo edital. Face ao impasse, recebemos, no entanto, há 10 dias um telefonema do Sr. Prefeito Reynaldo de Barros que explicou, na presença do eng. Speranzini, presidente da EMURB, não ter a prefeitura recursos, no momento para um empenho de verba que abrigasse a contratação de ambos os objetos previstos pelo edital; mas garantiu-me pessoalmente que a contratação do Plano Diretor seria efetivada dentro de 90 dias. Nestas condições aceitamos o encaminhamento dado pela EMURB, resultando na assinatura do primeiro contrato.

Ainda no sentido de dar obediência ao estabelecido pelo Edital, a ausência da carta de intenções de contratação, a ser firmada pela EMURB, mencionada no item 14.1, foi substituída pela Cláusula Vigésima do primeiro contrato, assim redigida: "A EMURB, ou quem a ela suceder, reconhece as CONTRATADAS como únicos autores do projeto de reurbanização do Vale do Anhangabaú, comprometendo-se com elas e somente com elas contratar o Plano Diretor e as demais etapas de implantação, constantes da proposta para concurso citado no início do contrato."

Parece-me que, destarte, fica respeitado o espírito do Edital organizado com colaboração do IAB.

Cumpre ainda em meu nome e no da colega Rosa Kliass, agradecer essa Diretoria pelo apoio que nos tem dado, no sentido de preservar os direitos garantidos pelo Edital e de levar a bom termo o Concurso.

Sem mais, subscrevo-me

Jorge Wilheim 
Sanadas as questões administrativas, no início de 1982 a revisão e desenvolvimento da proposta vencedora do Concurso teve seu início. Dado que a partir de 1983 Jorge Wilheim assumiria a presidência da SEMPLA e em 1987 seria convidado para a Secretária Estadual do Meio Ambiente, notamos, entretanto, que esta tarefa recaiu sobretudo sobre os arquitetos-paisagistas Rosa Kliass e Jamil Kfouri. É importante destacar também a participação ativa dos técnicos da EMURB, os quais segundo os autores foram de grande importância no processo uma vez que reconheciam por seu lado os méritos da proposta vencedora e buscavam, sempre que possível, colaborar para seu melhor desempenho face as exigências de obras públicas deste tipo.

\section{Diferenças entre o projeto Vencedor e o Projeto Implantado}

Iniciando pelas alterações realizadas na estratégia de resolução do conflito entre pedestres e veículos, notamos grandes diferenças em três pontos específicos: o desenho do Terminal e das travessias de pedestre na Praça da Bandeira; a geometria das alças de retorno nas cabeceiras dos túneis; e, talvez a mais importante, a eliminação da rampa de acesso e pontilhão curvo sobre a plataforma de pedestres para realização de conversões à direita e à esquerda na Avenida São João.

Quanto à realização das travessias de pedestre junto a Praça da Bandeira notamos que, apesar da manutenção do traçado original em arco conectando diretamente a região da Ladeira da Memória à Rua do Ouvidor, houve a redução significativa da qualidade ambiental e programática deste percurso. Ao invés das passarelas se articularem por meio da grande cobertura-jardim do terminal elas passaram a se articular por uma estreita faixa de piso. Quanto ao terminal, este ficaria descoberto até o ano de 1996 quando o então prefeito Paulo Maluf realizou a construção de sua atual cobertura, um projeto de características bastante diferentes do previsto inicialmente por Wilheim, Kliass e Kfouri. Maluf ainda criaria uma nova passarela, a qual tornaria o desenho da região ainda mais confuso. 


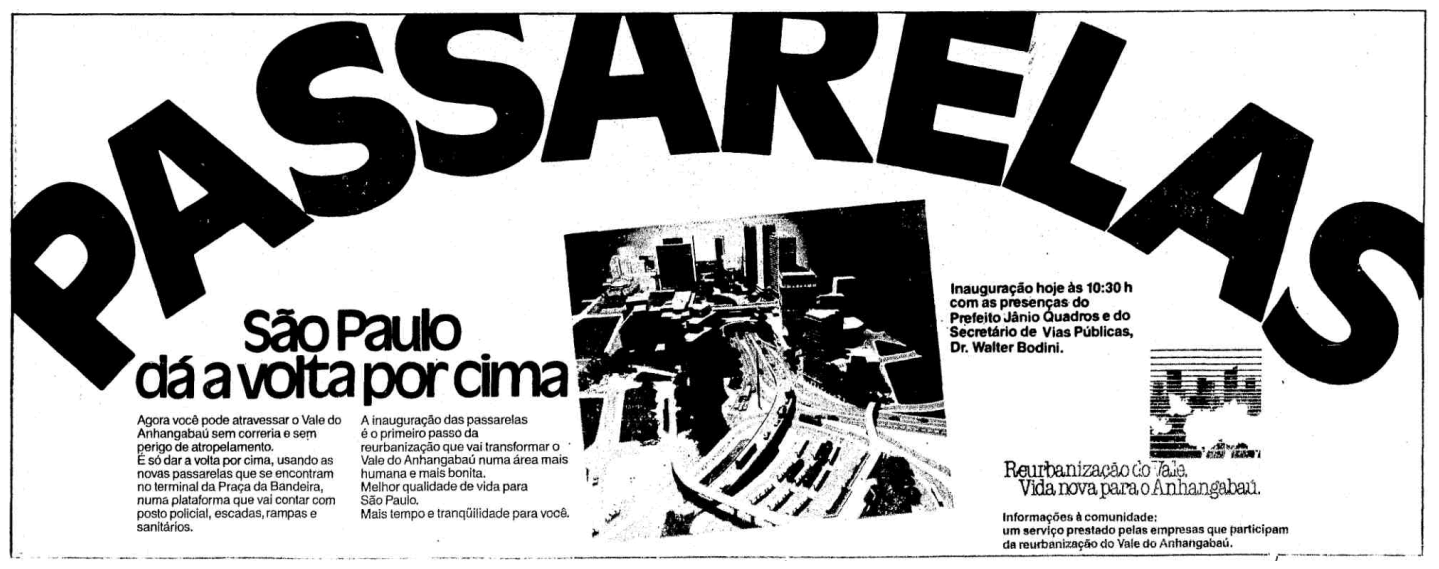

fig.82 Planfeto informativo da inauguração das passarelas do Terminal Bandeira, 1988

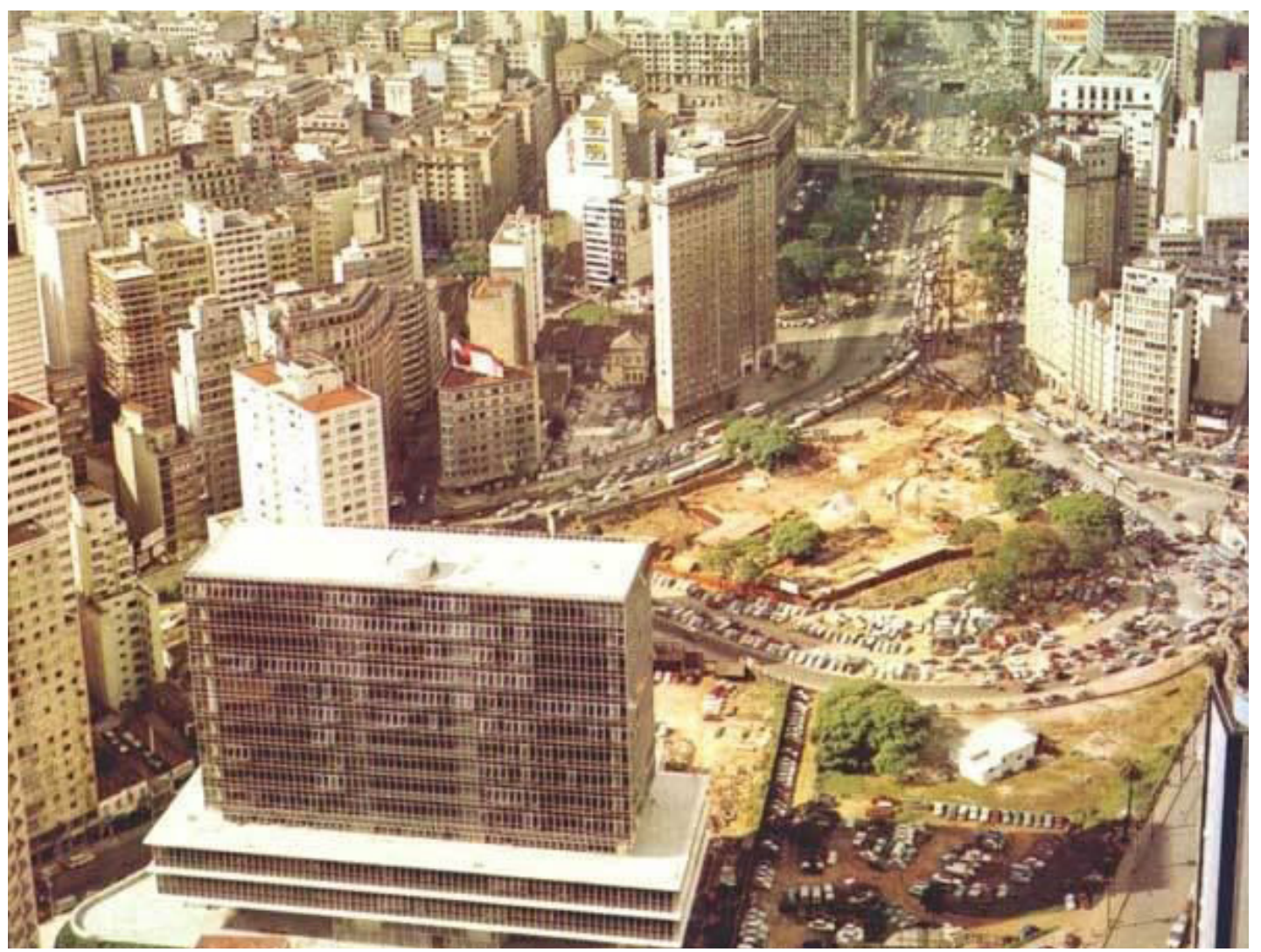

fig.83 Obras de implantação passarelas do Terminal Bandeira, década de 1980 
Já no que diz respeito ao desenho das alças de retorno notamos uma sutil diferença entre a proposta original e o projeto implantado, mas que segundo o arquiteto Jamil Kfouri, foi um dos pontos mais delicados e trabalhosos de todo o projeto. Segundo o arquiteto, logo que se iniciaram as consultas e aprovações do projeto com os órgãos competentes o traçado geométrico das alças propostas foram indeferidos e em seu lugar a Companhia de Engenharia de Tráfego (CET) exigiu um novo traçado geométrico mais 'folgado". Contudo, recorda Kfouri, "este novo traçado ou inviabilizava as rampas de acesso aos túneis ou avançavam sobre o espaço do pedestre”. Além do mais, continua Kfouri, "o CET, para não haver risco de queda dos automóveis, exigia a execução de muretas de proteção reforçadas e altas, algo que a nosso ver atrapalharia as visuais e a leitura de nossa proposta".

Um outro ponto de dificuldade imposto o desenho destas alças foram as fundações do viaduto Santa Efigênia, que ao se iniciarem as obras, revelaram-se muito maiores do que se imaginava, forçando a equipe a reestudar o todo traçado geométrico da proposta, incluindo as rampas de acesso, as alças de retorno e os próprios túneis, incorporando estas exigências práticas e funcionais, geralmente relacionadas ao dia-a-dia dos técnicos e engenheiros da prefeitura, ao trabalho dos arquitetos. Neste ponto Kfouri destaca:

"Nós então nos debruçamos sobre este problema no escritório e o redesenhamos à exaustão. Não bastava simplesmente atender aos raios, tangentes e distâncias mínimas dos manuais. Nós queríamos desenhar estas vias como elementos da paisagem, coerentes com todo o espaço do Vale, do desenho do piso e mobiliário ao uso do espaço, e não só com suas próprias regras e lógicas. Foi assim que redesenhamos tudo, até mesmo as muretas de proteção"32

Quanto à eliminação da rampa de acesso e pontilhão curvo para conversões à direita e à esquerda na Avenida São João, o arquiteto Jamil Kfouri esclarece que esta alteração não se deu de forma programada:

"Nós havíamos projetado e calculado toda a estrutura do pontilhão e as fundações e rampas de acesso já estavam executadas. Nós não gostávamos dele em absoluto, mas segundo nosso consultor de tráfego era uma necessidade do ponto de vista do fluxo esta

32 - Entrevista realizada em novembro de 2016 
ligação direta com a avenida São João, como poderíamos questionar?

Foi então quando um técnico da prefeitura depois de três anos de obra nos perguntou "Vocês ainda querem fazer o pontilhão? A ligação com a Avenida São João já não existe há três anos e o trânsito do centro não parece ter demonstrado pioras, parece que se acomodou.".

Era esse o motivo que precisávamos para removê-lo de lá. Retiramos o pontilhão, mas o buraco e toda a geometria para recebe-lo junto a avenida São João já estava feito...e o túnel já estava mais profundo do que precisava, não tinha mais volta. Então a Rosa e eu buscamos uma maneira de lidar com aquilo, foi aí que imaginamos aquela cascata e fonte que estão lá até hoje"

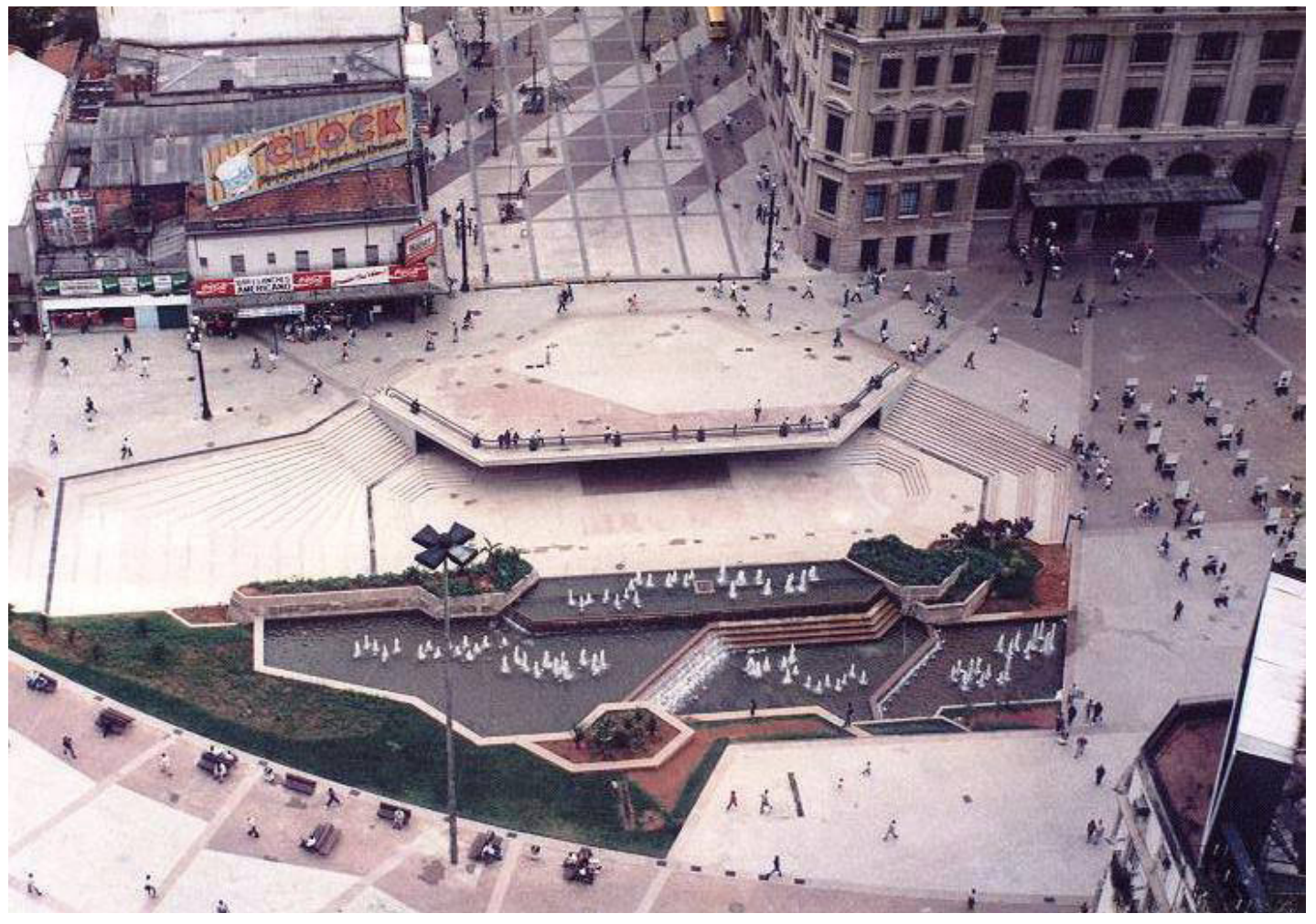

fig.84 No lugar do pontilhão, fonte e café rebaixado, 1992 - Eduardo Benzatti 


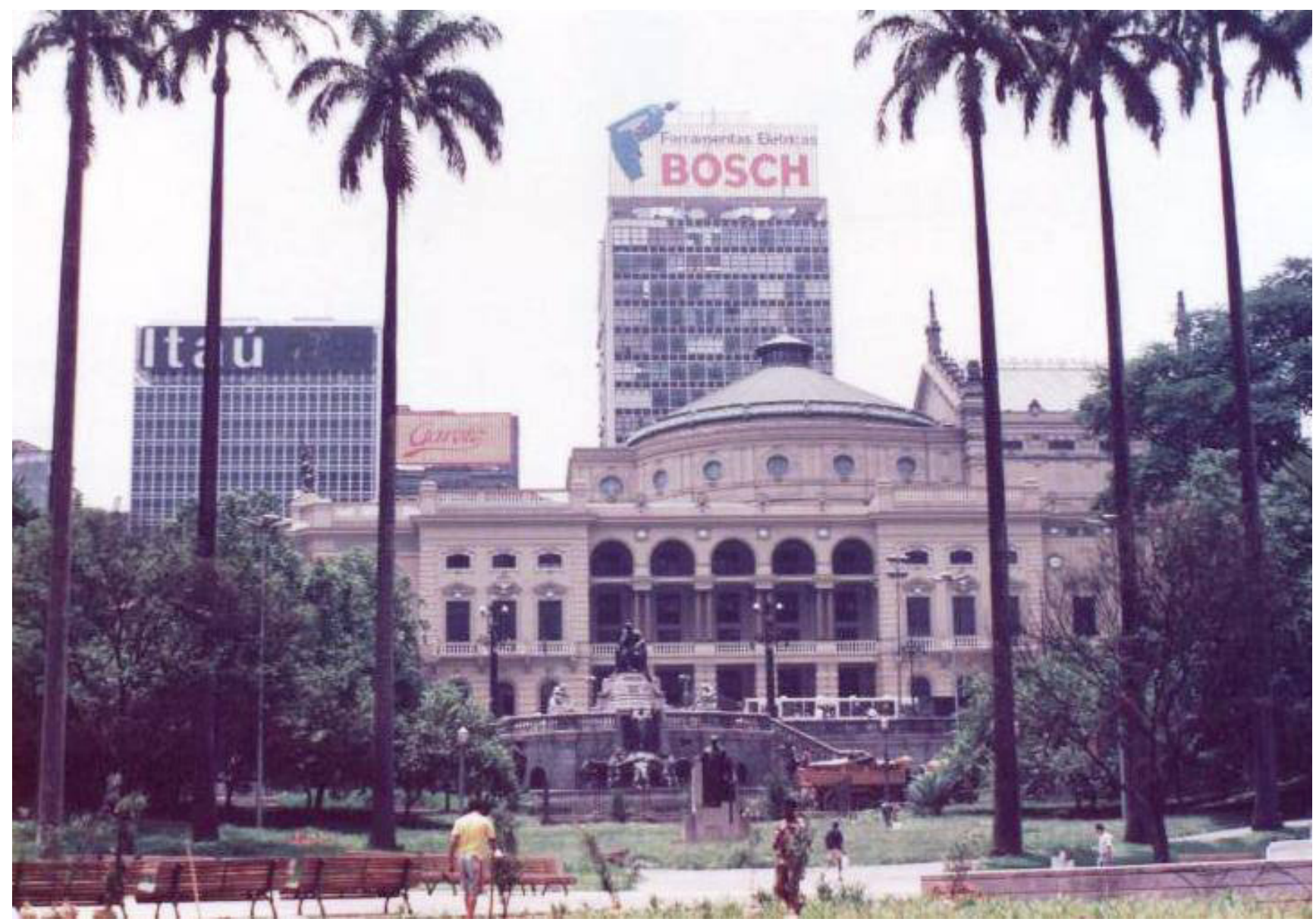

fig.85 Teatro

Municipal a partir do Vale, 1992 -

Eduardo Benzatti

fig.86 Tribuna e

Viaduto do chá a

partir do Vale, 1992

- Eduardo Benzatti
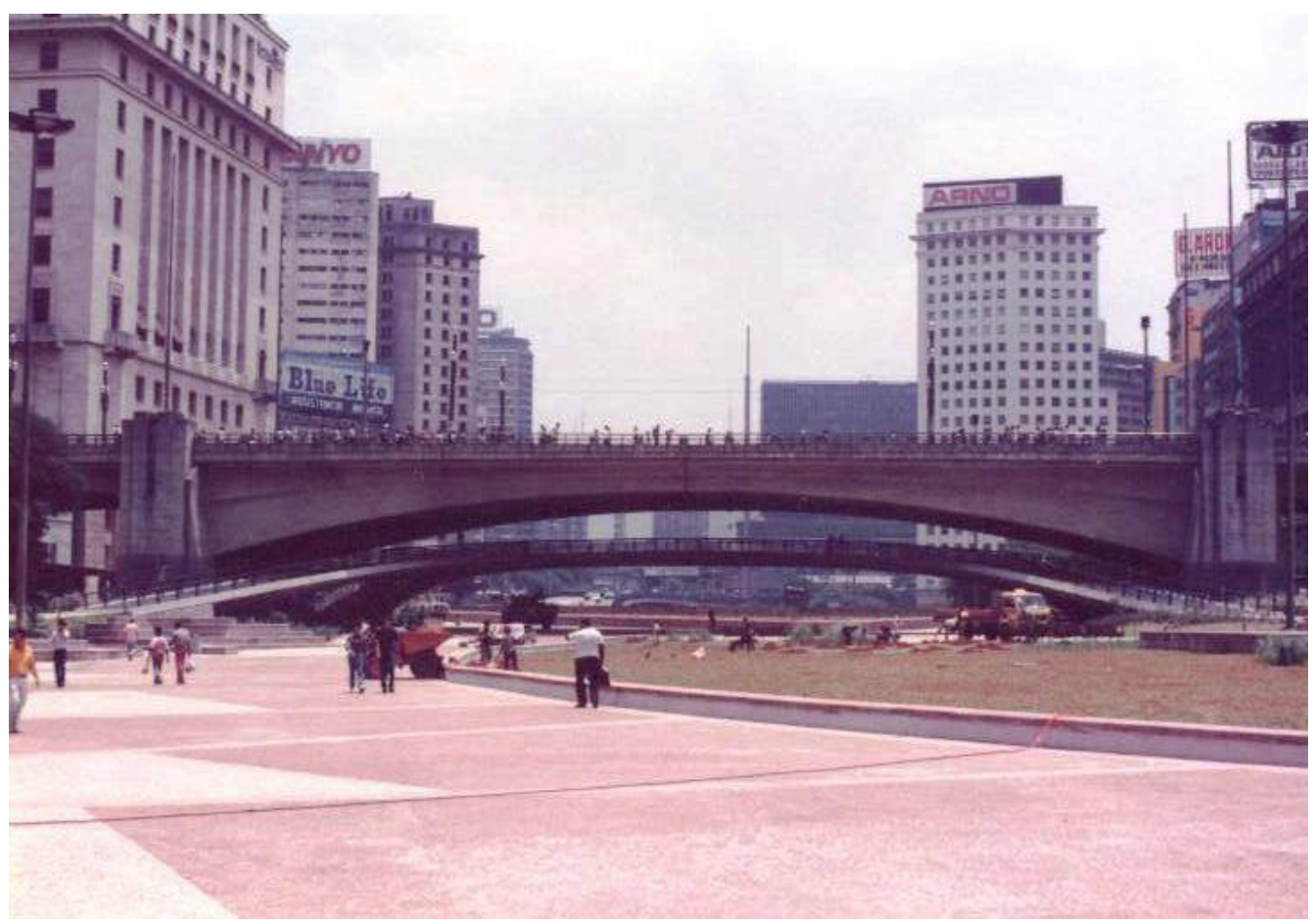

Reurbanização do Vale do Anhangabaú: propostas para recriação de uma paisagem 


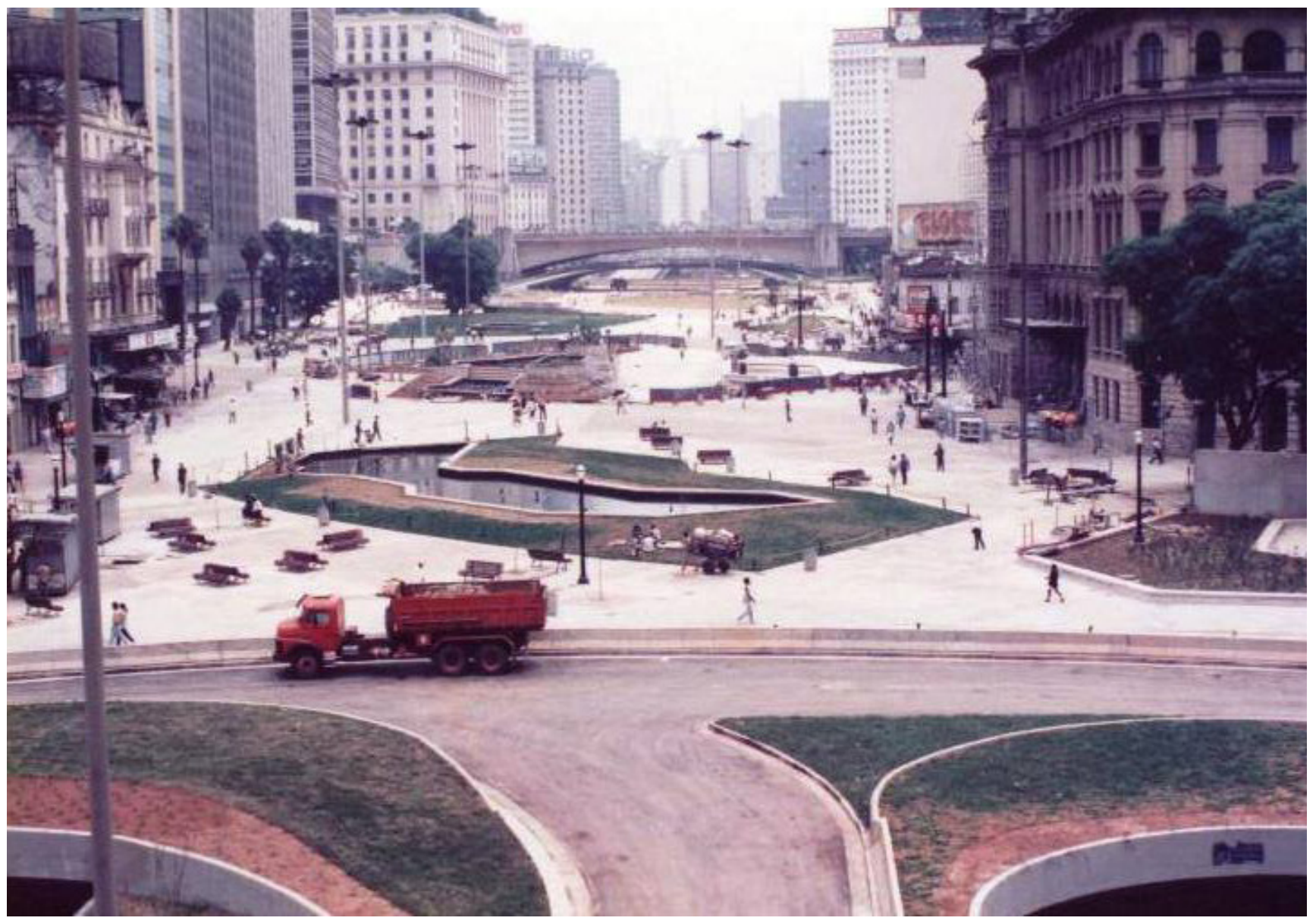

fig.87 Vista geral a partir da Praça Pedro Lessa, 1992 Eduardo Benzatti 
A semelhança do que vimos na resolução do conflito entre pedestre e automóveis, notamos que do ponto de vista do desenho dos espaços livres e programático há também alterações substanciais entre a proposta de 1981 e o projeto implantado em 1991. Começando pela dimensão e quantidade dos espaços abarcados, notamos que houve no trecho sul a desconsideração das áreas livres situadas para além da Ladeira da Memória (miolo de quadra do Edifício Touring), assim como a eliminação do calçadão na última quadra da Rua José Bonifácio. No trecho norte, por sua vez, devido a criação de alça de acesso à Rua Capitão Salomão a Praça Pedro Lessa foi seccionada em duas resultando na redução da área do playground e na desarticulação entre este e o bosque natural. Ainda neste trecho, na margem leste, foi também desconsiderado o terreno vazio situado a norte do Viaduto Santa Efigênia (fundos com o arrimo das Casa da Bóia) e a zona de aproximação à Estação São Bento foi bastante reduzida. No trecho compreendido entre os viadutos do Chá e Santa Efigênia, apesar da eliminação do calçadão de contorno ao Teatro Municipal, notamos que houve um significativo acréscimo de área, uma vez que foram eliminados as rampas de acesso e o pontilhão curvo de conversão à direita e à esquerda para à Avenida São João. Com isso e as porções leste e oeste da Avenida São João convertidas em calçadões em novembro de $1990^{33}$ puderam ser incorporadas ao Vale.

Ainda no trecho entre viadutos, observamos que houveram também mudanças significativas no que diz respeito ao desenho dos equipamentos propostos, tais como a praça de comícios, a tribuna, os cafés, o playground e as áreas de estar.

Começando pela praça de comícios e eventos populares, observamos que ela teve seu sentido invertido, transformando a arquibancada natural defendida no concurso em fundo para a tribuna. Com esta alteração, segundo os autores, objetiva-se valorizar o Teatro Municipal, tornando-o ponto focal da praça e assim incorporando-o ainda mais à paisagem do Vale. Tal efeito é ainda reforçado pelo desenho dos canteiros e do piso desenvolvido defronte ao Teatro, concêntrico e orientado à estátua de Ruy Barbosa.

Neste movimento a tribuna foi deslocada para margem oeste e adotou um desenho trapezoidal. A sua frente foi criado um extenso jardim, rodeado por um banco linear 33 - A ideia de transformar as primeiras quadras da Avenida São João em calçadão surge durante a gestão de Luiza Erundina com o advento da Operação Urbana Anhangabaú que, entre outras realizações, previa a criação do Boulevard São João. 
que poderia ser utilizado dos dois lados (voltado para o passeio e voltado para o jardim), porém após o plantio de arbustos em um dos seus lados e de arvores não planejadas em meio ao gramado esta função dupla foi perdida.

Outra alteração se deu na maneira como foram criados os pequenos recantos dentro deste espaço. Se na proposta original imaginava-se atingir este resultado por meio de múltiplos patamares e espelhos d'água, no projeto implantado os autores utilizam-se do desenho de piso, da alternação de materiais e da criação de três arquibancadas independentes para tal efeito. Na parte posterior destas arquibancadas os autores mantiveram o maciço de árvores, reduzindo-o parcialmente para realizar uma conexão direta com o espaço intermediário do Vale. A este espaço que inicialmente estava previsto a criação de um terraço e o incentivo à abertura de cafés e pequenos comércios teve de ser realizada a abertura de uma via compartilhada, impedindo desta forma a implantação destes programas.

Passando ao trecho entre a "grande praça" e a Avenida São João, originalmente destinado a abrigar a rampa de acesso à Avenida São João e um terraço para cafés, bares e lanchonetes, notamos que os arquitetos propuseram a criação junto à margem leste de um grande maciço arbóreo, composto sobretudo por sibipirunas (Caesalpina Pluviosa) e outras espécies de grande porte. Por de trás deste arvoredo e aproveitando-se de um renque de palmeiras imperiais pré-existentes, os arquitetos propuseram a complementação destas árvores realizando assim uma alameda de palmeiras. Entretanto, devido ao porte das plantas utilizadas e da falta de manutenção esta alameda nunca chegou a se conformar. Já na margem oeste apesar da manutenção da ideia do terraço, notamos que devido ao novo desenho do canteiro defronte ao Edifício CBI-Esplanada houve a diminuição significativa do espaço para o espraiamento do comércio.

No encontro com a Avenida São João, como dito anteriormente, o pontilhão curvo para conversão à direita e à esquerda foi eliminado, permitindo assim a ocupação do antigo leito carroçável nas duas quadras anexas ao Vale. Ao todo foram criados seis mil metros quadrados de calçadão, contando com a implantação de bancos de madeira, luminárias no estilo antigo, telefones públicos, caixas de correio, palco para atividades culturais e um pórtico de concreto aparente de 16 metros de altura. Contudo o núcleo de serviços imaginado para o térreo da esquina oposta ao Edifício do 


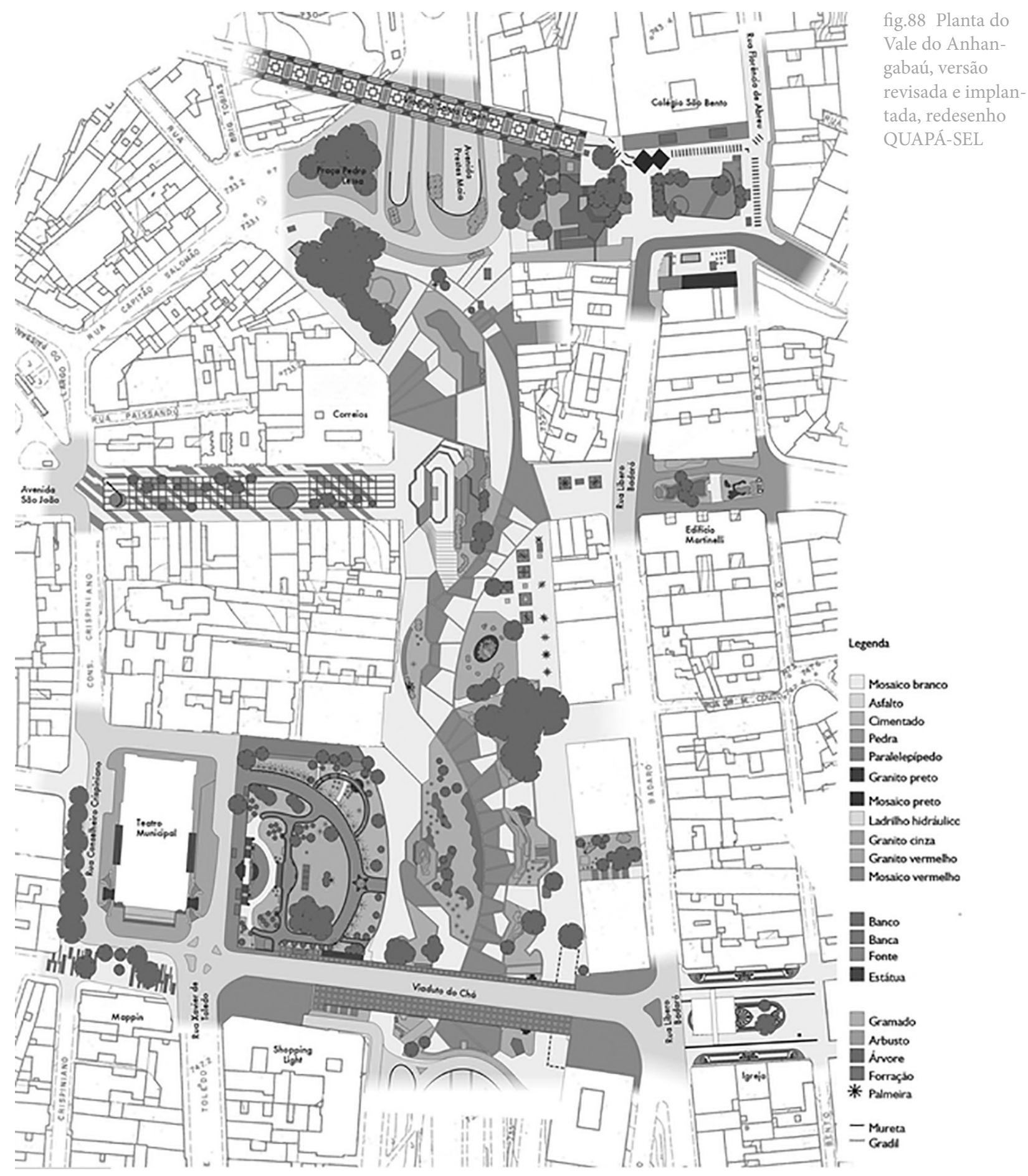

Reurbanização do Vale do Anhangabaú: propostas para recriação de uma paisagem 
Correio foi eliminado.

A eliminação do pontilhão também trouxe alterações para o desenho do leito do Vale, permitindo a criação de um Belvedere no eixo da avenida São João e de uma grande fonte-cascata em meio ao Vale. Sobre esta modificação Kfouri esclarece:

"Quando nos vimos livres do pontilhão mas já tínhamos o rebaixo do café definido nos preocupamos em como resolver aquele desnivel. Levantamos duas possibilidades: a primeira, mais imediata, seria realizar uma passarela que atravessaria aquele vazio a semelhança de como o pontilhão o faria; e a segunda, a qual achamos mais interessante e acabamos escolhendo, a de criar um Belvedere, um mirante, exatamente no eixo da São João, de onde as pessoas parassem no seu ponto mais baixo e avistassem, em primeiro plano uma bela cascata, e ao fundo, em continuidade à ladeira oposta da São João, o prédio do Banespa e o Martinelli"

Passando um pouco mais adiante, no trecho compreendido entre a Avenida São João e o Viaduto Santa Efigênia, notamos que apesar da manutenção das funções básicas (praça de acolhimento junto ao Edifício do Correio e praça de estar junto aos prédios da margem leste do Vale), houve o redesenho e redimensionamento dos espaços. $\mathrm{O}$ espelho d'água proposto inicialmente como delimitador da praça de acolhimento oeste por exemplo foi remanejada para o centro do Vale e ampliado, assim como os seus jardins de contorno. Com isto a porção central, anteriormente prevista como área de passagem e conexão direta entre as porções sul e norte do Vale foi eliminada e esta área incorporada às praças laterais. Quanto à praça de acolhimento do Correio, a semelhança do que foi feito no trecho defronte ao Teatro Municipal, criou-se um novo desenho de piso radial originado na porta de entrada do edifício desta instituição, amplificando sua importância e reforçando a relação deste com o espaço do Vale de forma simbólica.

Nas proximidades da Estação São Bento do Metrô, a semelhança do ocorrido na esquina sudoeste do cruzamento com a Avenida São João, vemos que o núcleo de serviços que contava com creche, lanchonete, banheiros e postos de informações e de serviços públicos foi eliminado. Quanto à praça Pedro Lessa, como mencionado anteriormente, esta foi subdividida em duas porções e a área de lazer e playground originais foram reduzidos consideravelmente. 
Por fim, considerando o subsolo do Vale notamos que, à semelhança do que outras equipes previam, os autores do projeto vencedor incluíram plataformas de embarque e desembarque para ônibus ao longo dos túneis sob a área de uso exclusivo de pedestres. Estas plataformas acessadas diretamente por escadas convencionais e com a previsão de espaço para a implantação de escadas rolantes, as quais de fato nunca foram instaladas.

Do ponto de vista da valorização do patrimônio histórico e do uso e legislação do solo as propostas que foram apresentadas pela equipe na ocasião do Concurso não foram levadas adiante, fato que seria parcialmente compensado pela criação da Operação Urbana Anhangabaú em 1991 que, apesar do caráter mais abrangente objetivava, entre outras coisas, também a atração de capital privado à área, a valorização do patrimônio ambiental e histórico do Vale, o adensamento e diversificação de usos e a volta do prestigio da região central. ${ }^{34}$

Entretanto, apesar da proximidade entre as ideias colocadas por estas duas propostas, o curto período de tempo de existência e o fracasso de sua implantação resultariam por inviabilizar resultados mais concretos. Sobre isso José Eduardo de Assis Lefévre, coordenador da implantação da Operação Urbana Centro, credita o fracasso da Operação Urbana Anhangabaú a dois aspectos: o primeiro devido à problemas burocráticos e a falta de estudos de viabilidade; o segundo devido ao limite restrito do aproveitamento dos benefícios na área central, fato que desestimulava e reprimia a demanda de investimentos. ${ }^{35}$

34 - FLORENCE, Luiz Ricardo Araújo - Planos para área Central : Análise crítica dos Planos de Intervenção e Operações Urbanas direcionados à área central da cidade de São Paulo - FAUUSP, 2001 35 - LÉFREVRE, José Eduardo de Assis - Palestra sobre " Operação Urbana Centro" concedida na 20a reunião do Clube das Ideias. 


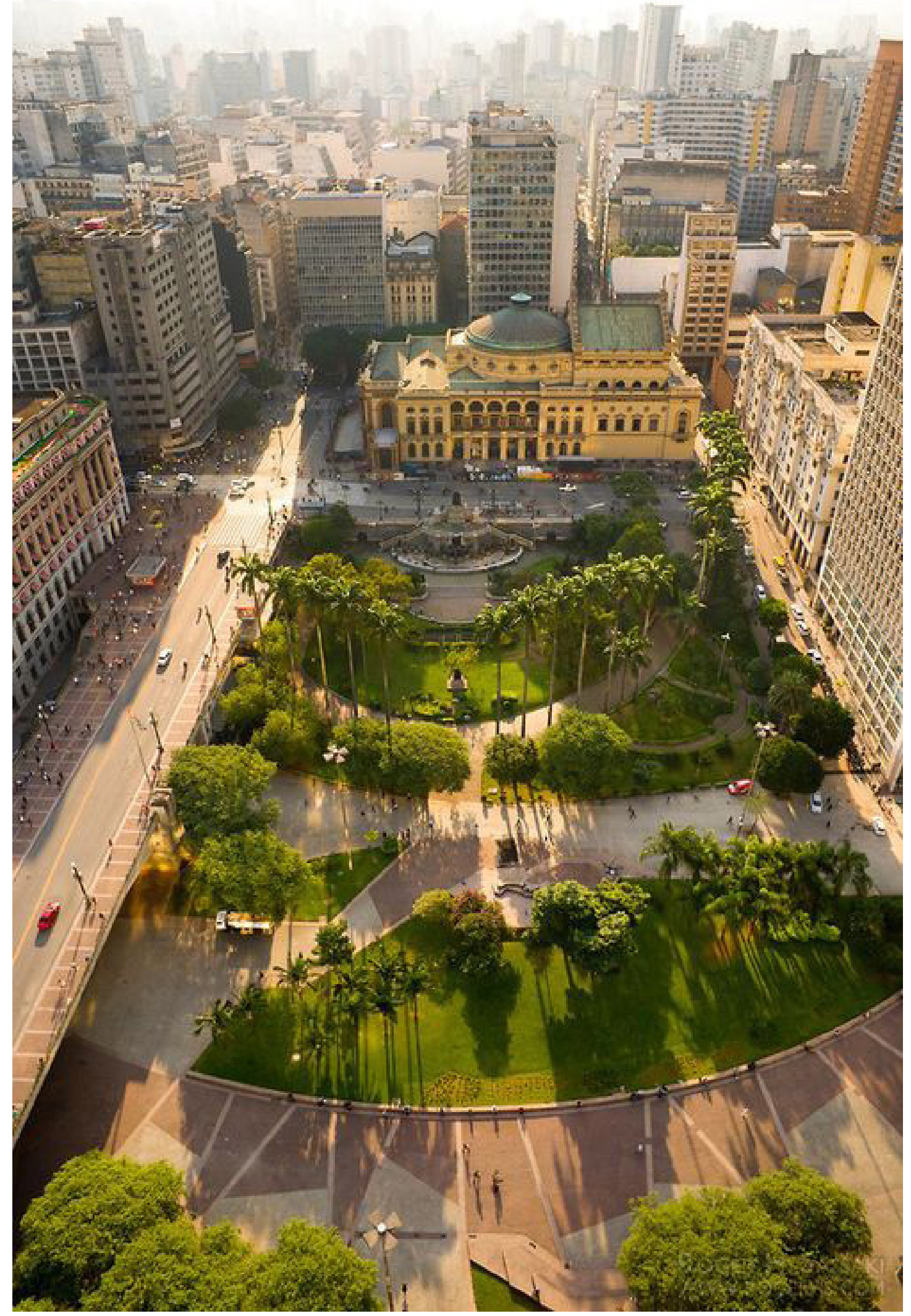

fig.89 Vista da tribuna, autor desconhecido 


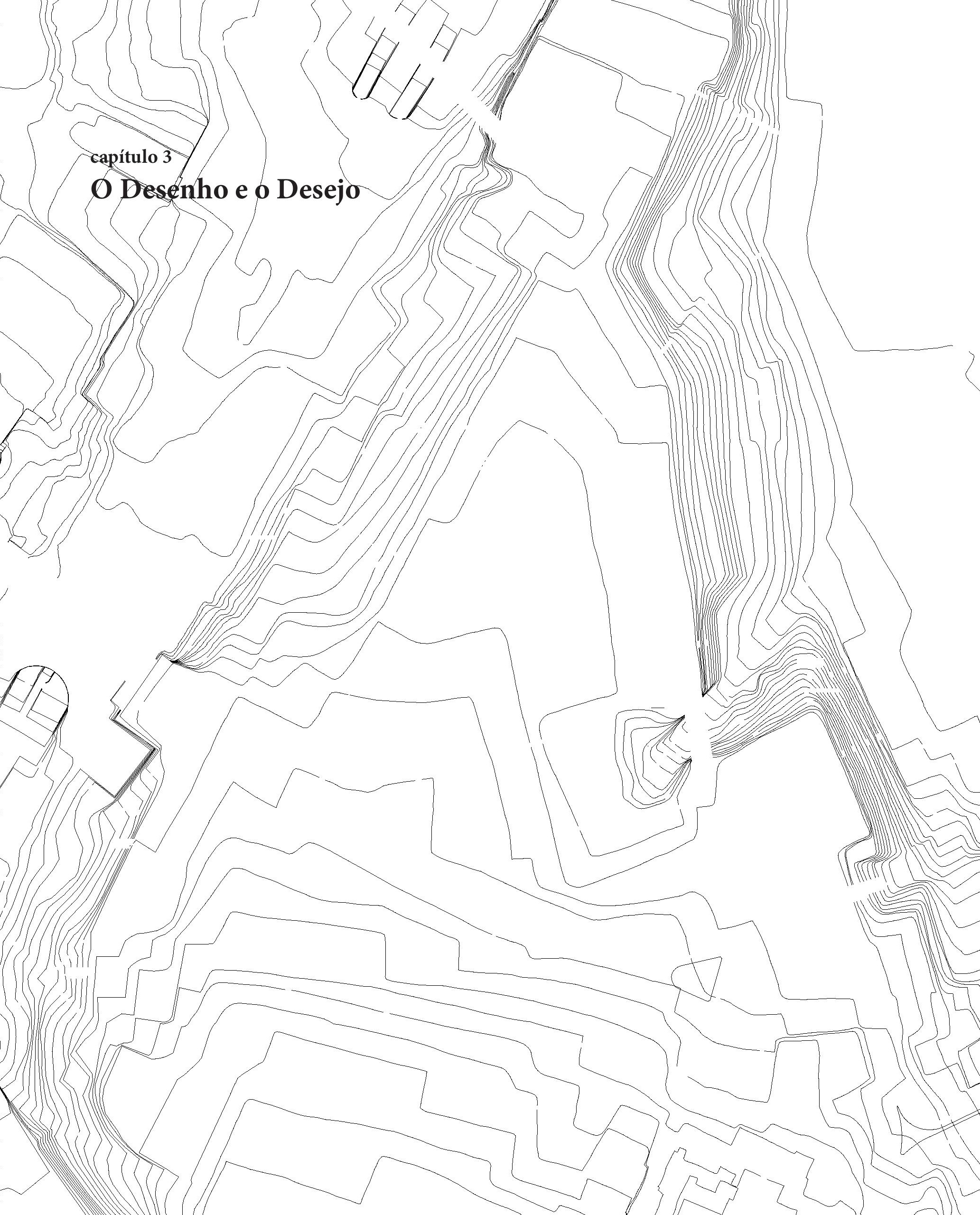


fig.90 Base topográfica fornecida pelo Concurso, acervo Aflalo / Gasperini

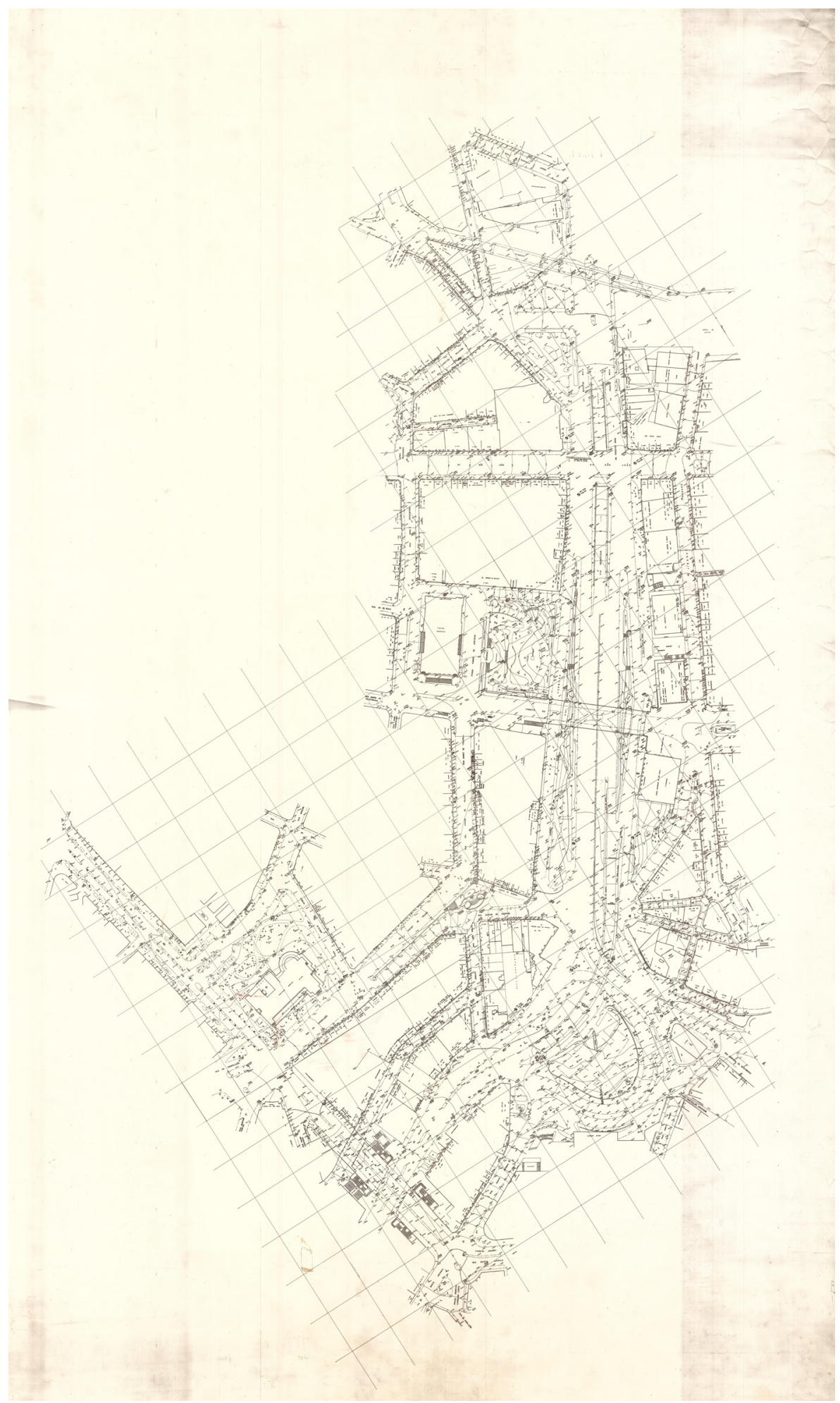




\section{A opção pelo Concurso}

Como vimos anteriormente, a opção pela realização de um concurso como meio para a seleção de um projeto para reurbanização do Vale do Anhangabaú em novembro de 1980 passa por uma série de fatores que somados contribuíram para tal decisão.

Do ponto de vista político notamos que o concurso surge como uma alternativa concreta pela redemocratização "lenta, gradual e segura"1 das decisões que dizem respeito ao espaço público. Esta afirmativa baseia-se no fato de, apesar deste formato permitir a participação da sociedade civil (população, arquitetos, IAB) na elaboração do desenho do Vale, esta faria-se sob o controle e anuência do Estado, uma vez que a elaboração do Edital, a escolha dos membros do júri e os cortes e adições ao projeto vencedor seriam realizados pela EMURB. Se tomarmos por exemplo os objetivos colocados pelo Edital do Concurso, notaremos que estes, apesar de convocarem a classe dos arquitetos para pensarem o Vale dentro de uma "solução global", tem como premissas fundamentais as mesmas estabelecidas anos antes pela EMURB para a realização do Projeto Anhangabaú em 1978, direcionando, portanto, as propostas para soluções que, se por um lado poderiam explorar novos desenhos, tratariam das mesmas questões anteriormente trabalhadas e tidas como fundamentais.

Neste sentido notamos como o processo participativo idealizado pelo IAB-SP, o qual 1 - Ao assumir a presidência do Brasil em 1974 o General Ernesto Geisel instaura seu plano de Abertura Política, que previa devolver de "lento, gradual e seguro" as liberdades perdidas desde a implementação do regime militar em 1964. Dentre as medidas tomadas estavam previstas a libertação e anistia dos presos políticos; o desmantelamento gradual dos aparelhos de repressão política; o fim da censura aos meios de comunicação; o fim da intervenção estatal nos sindicatos, movimentos estudantis, eclesiásticos e demais organizações sociais; realização de eleições periódicas; criação de partidos políticos e a devolução gradativa do poder à sociedade civil. Em 20 de dezembro de 1979 foi aprovada a Lei Federal n 6.797, restabelecendo o pluripartidarismo no Brasil. Em 15 de janeiro de 1980 seriam fundados o Partido do Movimento Democrático Brasileiro (PMDB) e em 10 de fevereiro de 1980 o Partido dos Trabalhadores (PT). Ainda em 17 de junho de 1979 havia sido criado em Lisboa o Partido Democrático Trabalhista (PDT). 
poderia ter alterado este quadro unilateral por meio do "debate e a troca de ideias entre técnicos, órgãos de planejamento e população", conforme defendido pelo Instituto, nada contribuiu para a realização do Edital nem para as considerações do Júri, uma vez que aquele foi concluído cerca de três meses antes da realização dos debates e seminários e o júri, conforme escrito na ata de julgamento, baseou-se exclusivamente nos "objetivos estabelecidos no Edital, no programa e demais documentos fornecidos".

Outro ponto a ser destacado acerca dos debates e seminários organizados pelo IAB é como estes tiveram pouca penetração dentro da sociedade civil e demais categorias profissionais. Conforme descrito pela reportagem da revista A Construção São Paulo de abril de 1981, "talvez por tratar-se de inciativa pioneira, o seminário sobre a reurbanização do Anhangabaú não motivou a participação ativa de diversos segmentos representativos da comunidade nos debates e da apresentação de sugestões que contribuíssem, de fato, para alimentar o processo do Concurso". Um pouco mais a diante a mesma reportagem continua, "nos quatro dias do seminário (...) a única intervenção que pôde ser caracterizada como manifestação de um segmento organizado da população foi a de um diretor do Sindicato dos Bancários: "o Vale é atravessado diariamente por mais de 40 mil bancários (...) que diariamente se sujeitam ao risco de atropelamento. Não queremos uma paisagem "bonitinha", cheia de concreto e jardim suspensos, que o povo não use. O povo prefere descobrir e usar suas próprias soluções".

Somando-se a estas constatações de ordem prática, notamos como o conteúdo das discussões dos grupos de trabalho se concentraram não em torno da discussão projetual e programática do Vale, mas sim em torno de questões organizacionais da classe dos arquitetos, de discussões políticas e posicionamentos ideológicos. Não por menos, conforme os relatos colhidos por esta pesquisa junto aos membros das equipes premiadas, notamos como tais debates pouco contribuíram com as propostas premiadas, revelando assim que apesar da intenção original Concurso de "democratizar" o projeto para o Vale, este ainda assim se deu exclusivamente dentro de uma esfera técnica.

Contudo, se o Concurso se revelou como uma tentativa fracassada de democratização do desenho do espaço público, é notável como ele inaugura um novo momento 
dentro da produção do espaço urbano brasileiro. É a partir deste evento que observaremos o surgimento desta forma de contratação e planejamento dentro das administrações públicas municipais de todo Brasil, destacadamente da cidade de São Paulo. Conforme destaca SANTOS ${ }^{2}$, somente entre os anos de 1989 e 2000 ao menos sete novos concursos municipais foram lançados para a reconfiguração de áreas urbanas, estratégia amplamente utilizada até hoje como alternativa mais ágil à lei de licitações ${ }^{3}$. Todavia, dado ao aumento da midiatização e ao baixo índice de concretizam das propostas, não estariam os concursos públicos de arquitetura tornando-se antes uma forma de promoção de seus promotores e concorrentes do que um instrumento real de transformação e intervenção no espaço público urbano?

Por outro lado, considerando a historiografia da arquitetura, podemos destacar como a opção pelo concurso possibilitou a abertura para novas abordagens e estratégias projetuais em meio ao regime militar brasileiro. É com o advento do concurso que vemos surgir alternativas ao desenho urbano de caráter estritamente funcional e setorial que vinha sendo desenvolvido pelo governo na última década na cidade de São Paulo, materializado sobretudo em obras como o Elevado Costa e Silva (1970) e Praça Roosevelt (1970), mas também presente em planos e projetos de grandes arquitetos da época, como o próprio plano de Artigas (1974) e da EMURB (1978-80) para o Vale do Anhangabaú. Face a esta realidade o concurso ofereceu visões urbanas comprometidas não só com os aspectos de fluxo, função e dimensionamento do espaço, mas também abertas aos aspectos figurativos, emocionais, sensoriais e, sobretudo, sociais do espaço urbano, demonstrando a transição de uma leitura puramente técnica para uma leitura mais sensível da paisagem e da vida em comunidade.

Neste sentido, considerando à tese de Alain Roger onde as transformações in situ na

2 - Segundo levantamento realizado por Valéria Cassia dos Santos, entre os anos de 1989 e 200 foram realizados pela PMSP os seguintes concursos: Conjunto Habitacionais Brás e São Francisco, Concurso para Revitalização do Bexiga, Concurso de Ideias para Avenida Paulista, I Concurso de Ideias para Novo Centro de São Paulo, II Concurso de Ideias para Novo Centro de São Paulo, Concurso de Ideias São Paulo Eu te amo, Concurso de Ideias das Marginais.

3 - Sobre o processo para a contratação de projetos para obras públicas no Brasil, Santos (2002) destaca três momentos: o primeiro em 1935 quando, a partir das recomendações realizadas pelas as organizações de classe para escolha de obras públicas exclusivamente via concurso público, aprovou-se a Lei Federal $125^{\circ}$ que exigia a realização de Concurso para edifícios públicos de grandes proporções; a segunda em 1966 com a promulgação da Lei no 5.194 que estipularia que os trabalhos profissionais relativos a projetos não poderiam ser sujeiros a concorrências de preço, devendo ser objeto de concurso; e o terceiro em 1993 com a promulgação da Lei 8.666 que trata das normas de licitação e contratos com a Administração Pública e define como modalidades de licitação a "concorrência; tomada de preços; convite; concurso; leilão". 


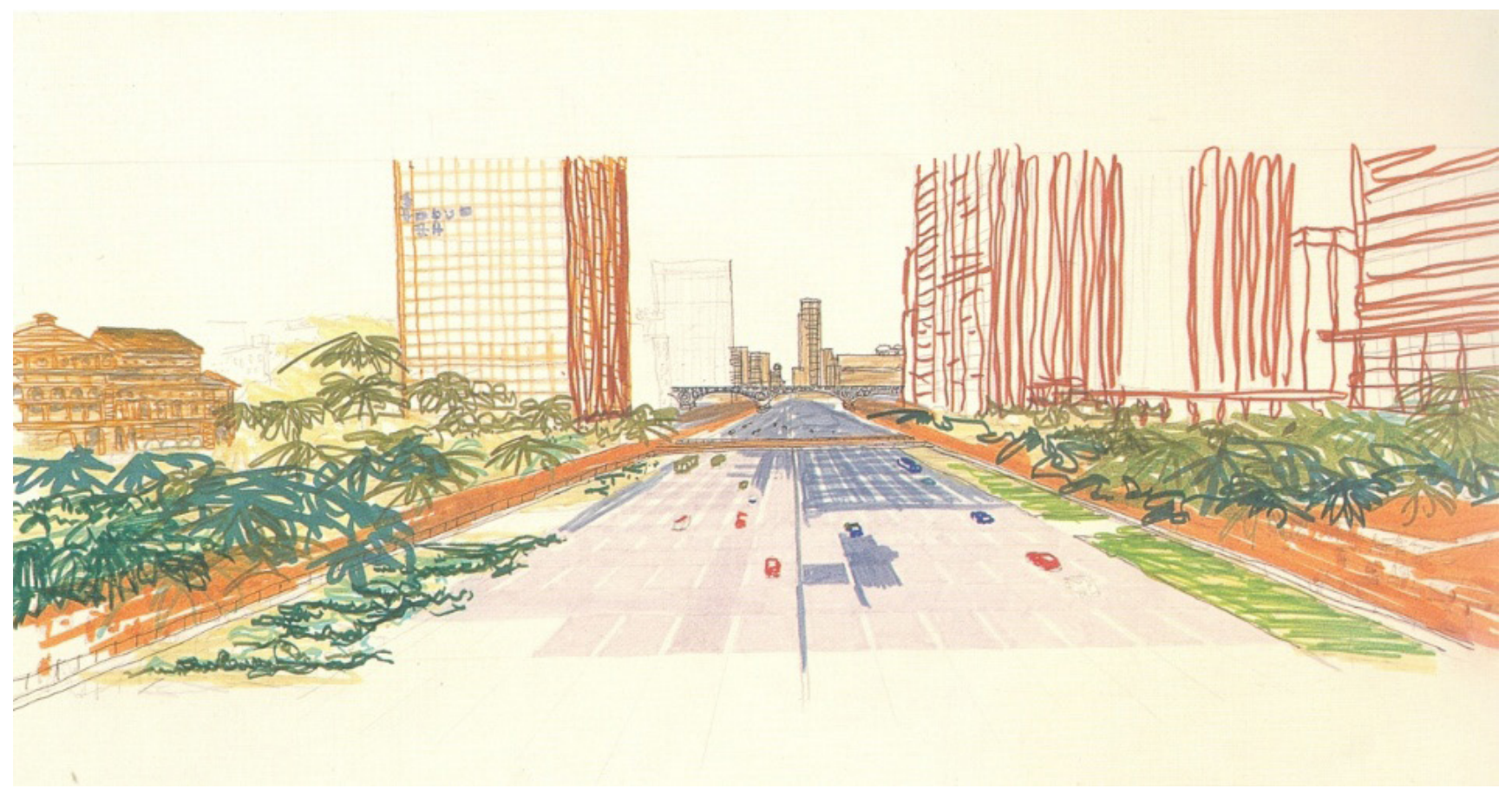

fig.91 Perspectiva do projeto desenvolvido por Vilanova Artigas, 1974 acervo FAU-USP 
paisagem são antecedidas pelas transformações in visu $u^{4}$ e o histórico de metamorfoses do Vale do Anhangabaú, podemos afirmar que as propostas apresentadas ao concurso para reurbanização do Vale traziam não só outras maneiras de se pensar e fazer arquitetura, mas continham em seu interior novos desejos e expectativas para o espaço público urbano, uma nova autoimagem que se pretendia encarnar e se fazer entender na paisagem paulistana. Em outras palavras os projetos para a reurbanização do Vale do Anhangabaú foram também projetos para sua ressignificação.

Cabe ressaltar também como o concurso evidencia a ascensão de uma nova geração de arquitetos formados em sua maioria a partir de meados dos anos de 1950 e anos 60 e graduados não mais no eixo Rio-São Paulo, mas no eixo São Paulo-Curitiba. Tal característica faz-se ainda mais perceptível se considerarmos o fato do corpo de jurados ser composto em sua maioria por membros advindos da "Escola Carioca" (Eduardo Corona, Edgar Graeff e Fernando Chacel) enquanto entre os premiados não há nenhum representante do Rio de Janeiro.

Sobre este deslocamento é importante notarmos como a "Escola Paranaense" foi, em sua composição inicial, fortemente influenciada pela "Escola Paulista". Segundo Paulo Cesar Pacheco, além de figuras de destaque como Vilanova Artigas e Wilheim que desenvolveram projetos de porte em solo paranaense entre as décadas de $1940 \mathrm{e}$ 1970, a influência paulista faz-se ainda mais sensível pela atuação de muitos jovens arquitetos que, formados em São Paulo no último quarto dos anos 50, migraram para Curitiba a partir no início dos anos 60 e contribuíram tanto com a criação do curso de Arquitetura e Urbanismo da UFPR e da PUC quanto fizeram parte do chamado "Grupo Paraná"5. Neste ponto destacamos a participação de Rosa Kliass na criação e coordenação do Curso de Arquitetura e Urbanismo da Universidade Católica do Paraná e de Joel Ramalho Junior como docente na UFPR e PUC-PR, ambos premiados pelo Concurso em 1981.

4 - Para Roger existe uma distinção clara entre duas formas de artilizar a natureza. A primeira é direta e realiza-se in situ, ou seja, tal qual uma tatuagem opera diretamente sobre o objeto. A segunda, em contrapartida, é indireta, in visu, e realiza-se através da mediação do olhar. Enquanto a primeira é importante para converter em arte um objeto neutro (no caso a natureza), a segunda faz-se necessária por impregnar o olhar e torná-lo capaz de, a partir do reconhecimento de modelos, embelezar à distância

5 - Segundo Paulo Cesar Pacheco, "Grupo do Paraná" é a expressão comumente utilizada para se referir aos arquitetos vencedores de concursos de Curitiba durante as décadas de 60 e 70 . Ainda segundo ao autor, verifica-se que tal expressão surge em decorrência da postura adotada pelos projetistas paranaenses da época que, características à parte, atuavam náo de forma individualista, mas conjuntamente em equipes que traduziam a soma de diferentes habilidades. 


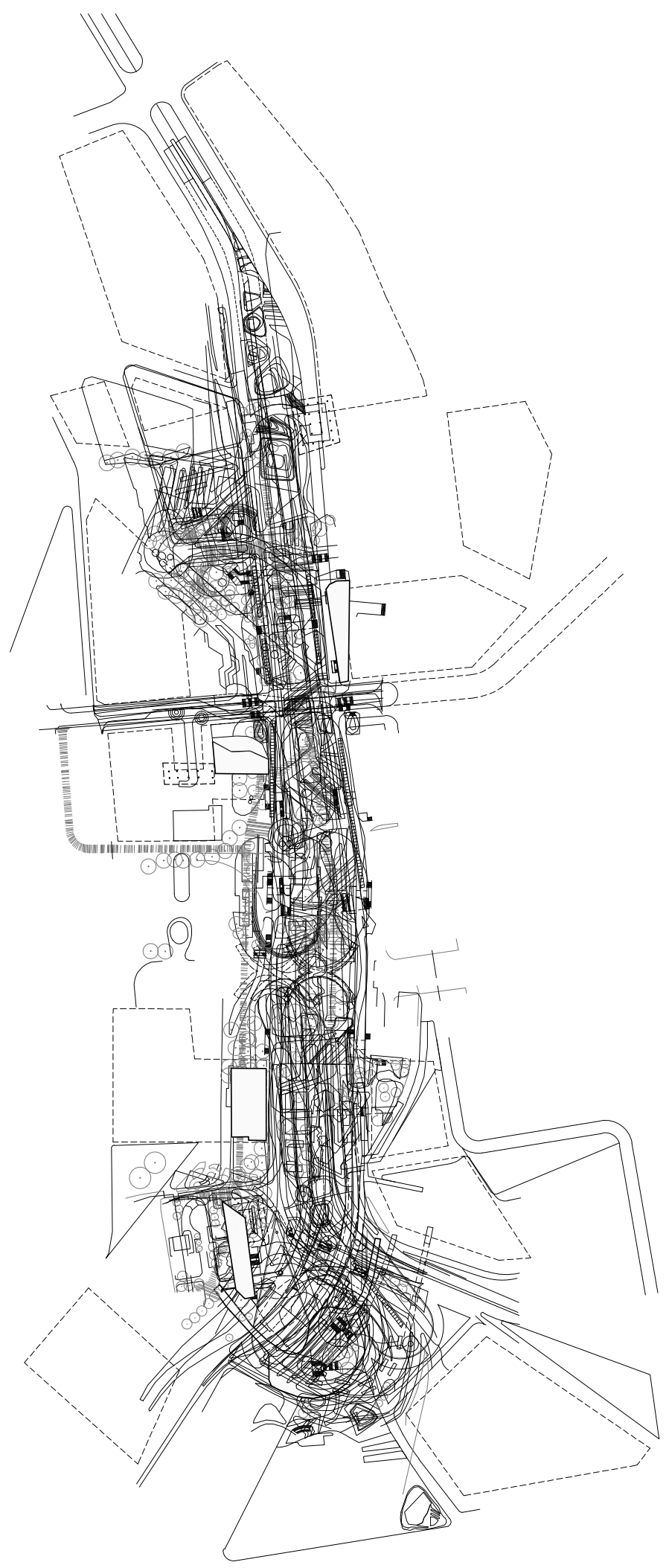

Reurbanização do Vale do Anhangabaú: propostas para recriação de uma paisagem 


\section{Considerações sobre as propostas}

A análise do conjunto das propostas premiadas pelo Concurso permite o estabelecimento de algumas considerações acerca da produção arquitetônica-paisagística do início dos anos 80 no Brasil, tornando possível assim, identificar quais eram alguns dos conceitos, referências e autores que balizavam a produção nacional da época.

Todavia, a análise comparativa de propostas tão heterogêneas e complexas como as premiadas pelo Concurso de Reurbanização do Vale do Anhangabaú exige a eleição de uma metodologia capaz de lidar de maneira abrangente com todas estas variáveis, tomando-as, não de maneira isolada e independente, mas de maneira relacional e integrada.

Tendo isto em vista, propomos aqui a utilização da metodologia defendida por José Lamas $^{6}$ para o estudo da forma urbana, onde a pretendida análise "precede de uma divisão do meio urbano em partes e da articulação destas entre si e com o conjunto que as definem". Para tanto o autor apresenta como instrumentos de análise um conjunto de aspectos (organização funcional, qualitativos e figurativos) e de dimensões espaciais (setorial, urbana e territorial) que, combinadas entre si, permitem a realização do parcelamento dos "elementos que definem e constituem o espaço urbano" assim como sua inter-relação em diferentes níveis, diferenciados pelas unidades de leitura e de concepção.

Segundo Lamas (1993) os aspectos da organização funcional são todos aqueles relacionados aos usos e atividades humanas desempenhadas em dada área, edifício ou espaço público, tais como o habitar, o comerciar, o trabalhar, o locomover-se, o re-

6 - LAMAS, José M. Ressano Garcia - Morfologia Urbana e Desenho da Cidade. Fundação Calouste Gulbenkian, 1993. fig.92 Página ao lado sobreposição dos seis projetos analisados, acervo do autor 
crear-se, o reunir-se, etc. Já os aspectos qualitativos são aqueles que se relacionam ao tratamento dos espaços, ao conforto e à comodidade do utilizador. Quanto ao aspecto figurativo, entendem-se este como o aspecto essencialmente responsável pela comunicação estética do espaço, entendendo-se estética como a capacidade de relacionar-se física e emocionalmente com os usuários e toda a sociedade.

Quanto às dimensões do espaço, Lamas (1993) define a dimensão setorial como “a mais pequena unidade ou porção de espaço urbano, com forma própria definida a partir de uma infinidade de elementos que organizados entre si definem a forma urbana, tais como edifícios, o traçado, a estrutura verde, o mobiliário urbano. Quanto à dimensão urbana, pressupõe uma estrutura de ruas, praças e demais formas urbanas de escalas inferiores que se relacionam entre si, constituindo a dimensão de um bairro. Quanto à dimensão territorial, é aquela que se estrutura através da articulação de diferentes formas à dimensão urbana.

Afim de realizar um recorte que seja comum à todas as propostas, dentre os inúmeros elementos que compõem estes aspectos da forma urbana destacaremos aqui aqueles que foram expressamente colocados pelo Edital, ou seja, o locomover-se, entendido principalmente como a resolução do conflito entre pedestres e automóveis; a organização das paradas e circuitos de ônibus; o uso e a destinação do espaço público e o uso e regulação do solo.

Partindo do aspecto da locomoção ${ }^{7}$, é possível agruparmos as propostas premiadas em dois grupos distintos, sendo um primeiro grupo composto pelas propostas que se utilizaram de uma estratégia de rebaixamento do sistema viário no sentido norte-sul e criação de uma grande plataforma exclusiva para pedestres na superfície do Vale estratégia à qual chamaremos de Túnel-Plataforma-; e um segundo grupo composto

\footnotetext{
7 - Colocado como tema central dentro do Edital do Concurso, a resolução dos fluxos de pedestres e veículos do Vale do Anhangabaú precisava lidar antes de mais nada com dois vetores principais de tráfego: o primeiro de caráter metropolitano no sentido norte-sul-norte, definido pela confluência das avenidas Vinte e três de maio e Nove de Julho até a avenida Prestes Maia, o chamado sistema " $Y$ ", por onde circulavam 12.200 veículos/hora na época; o segundo de caráter local no sentido leste-oeste-leste, realizado por cerca de 1 milhão de pedestres que transitavam diariamente entre a colina histórica e o centro novo de São Paulo.Somando-se a estes dois vetores principais existiam ainda outros três vetores que deveriam ser considerados pelos participantes do concurso. O primeiro seria a vetor sul-oeste, realizado pela ligação com a avenida São João junto à praça do Correio, por onde circulavam aproximadamente 2500 veículos/hora. Outro vetor de grande importância seria o gerado pelas estações de metrô São Bento e Anhangabaú, com a expectativa de conjuntamente atenderem aproximadamente 150.000 usuários dia. Por fim, havia também um vetor até então difuso é que deveria passar por uma organização gerado pelas 125 paradas de ônibus presentes no entorno do vale.
} 
pelas propostas que adotaram a criação de uma sequência de terraços e valas, que posicionados longitudinalmente ao Vale e articulando-se por meio de passarelas, escadas e rampas, possibilitavam o fluxo desimpedido e ininterrupto em todas as direções, tanto para os pedestres quanto para os veículos que por ali circulavam - a esta estratégia chamaremos de Terraço-Vala.

Ao primeiro grupo (Túnel-Plataforma) incluímos as propostas de Jorge Wilheim, Rosa Kliass e Jamil Kfouri (WKK), Elgson Gomes (EG), Paulo Bastos e Siegbert Zanettini (BZ), respectivamente primeira, segunda e terceira colocadas, e a proposta de Croce, Aflalo e Gasperini (CA\&G), classificada como segunda menção honrosa. Já ao segundo grupo (Terraço-Vala) incluímos os trabalhos de Joaquim Barretto e Carlos Bratke (BB) e Marcos Acayaba, Edgar Dente e Julio Katinsky (ADK), respectivamente $3^{\mathrm{a}}$ e $4^{\mathrm{a}}$ menção.

Quanto aos trabalhos de Joel Ramalho e Leonardo Oba (RO) e Paulo Kawahara e Celso Tanaka (KT), respectivamente $1^{\text {a }}$ e $5^{\text {a }}$ menção honrosa, dada a falta de material para uma análise mais profunda, não os consideraremos nesta análise.

Destacados os dois grupos supracitados, notamos como é possível estabelecer uma correlação entre as estratégias eleitas pelos autores e as "atmosferas" pretendida por estes para o espaço do Vale. Enquanto por um lado as quatro equipes que buscavam restituir ao Vale o Parque do início do século XX optaram pela estratégia Túnel-Plataforma, como que eliminando o solo historicamente construído e introduzindo um novo plano de intervenção, um reset no centro de São Paulo; por outro notamos que os autores que buscavam valorizar a passagem e imagem urbana construída sobre o Vale durante os anos 50 e 60 optaram pela estratégia Terraço-Vala, como que se negando a recompor o espaço histórico, mas metamorfoseá-lo a partir da modelagem 8 - Sobre o conceito de atmosfera Peter Zumthor afirma: "La atmósfera habla a una sensibilidad emocional, una percepción que funciona a una increíble velocidad y que los seres humanos tenemos para sobrevivir. Hay algo dentro de nosotros que nos dice enseguida un montón de cosas; un entendimiento inmediato, un contacto inmediato, un rechazo inmediato.Ahora bien, ¿qué me conmueve? Todo. Todo, las cosas, la gente, el aire, los ruidos, los colores, las presencias materiales, las texturas, y también las formas. Formas que puedo entender. Formas que puedo intentar leTer. Formas que encuentro bellas. ¿Y qué más me ha conmovido? Mi propio estado de ánimo, mis sentimientos, mis expectativas cuando estaba sentado allí. Me viene a la cabeza esa célebre frase inglesa, que remite a Platón: "Beauty is in the eye of the beholder" ["La belleza está en los ojos de quien mira"]. Es decir: todo está solamente dentro de mí. Y nunca hubiera tenido tales sentimientos sin esa atmósfera. Hay un intercambio entre las personas y las cosas. Con eso tengo que tratar como arquitecto. Y pienso: ésta es mi pasión. Existe una magia de lo real. Conozco muy bien la magia del pensamiento. Y la pasión del pensamiento bello. Pero me refiero a algo que, con frecuencia, encuentro más increíble: la magia de lo verdadero y de lo real. - ZUMTHOR, Peter. Atmosféras. Gustavo Gili, 2003 
de seus próprios elementos.

Deste quadro, portanto, podemos depreender não só duas visões espacialmente distintas, mas, também, temporalmente diversas. A primeira trata a se remeter à uma imagem da cidade pré-metropolitana, uma São Paulo dos anos 20, 30 e 40, onde o Anhangabaú era visto como o Jardim, primeiramente, e depois a Sala de Visitas da cidade. O Vale era um espaço encerrado em si, estático, paisagem de escala doméstica, uma exceção que se colocava como referência em meio à cidade. Não por menos é neste grupo que notaremos as propostas mais atentas em relacionar o espaço do vale dentro de sua dimensão urbana ${ }^{9}$, com suas encostas e entorno imediato, com a vida cotidiana dos usuários e frequentadores do Centro.

A segunda visão, por sua vez, remete-se à imagem de uma cidade de largo alcance, distendida tanto em sua dimensão horizontal quanto vertical, de avenidas extensas e prédios cada vez mais altos. Uma São Paulo crescente, sem limites, em movimento, onde o Anhangabaú deixa de ser Paisagem e torna-se Passagem. Seu papel não é mais o do Jardim ou o da Sala de Estar, mas o de Galeria, onde a relação com o espaço se dá em movimento e o fato exposto passa a ser a própria Cidade. São nestas propostas que encontraremos as abordagens onde o Vale é mais explorado em sua dimensão territorial $^{10}$, relacionando-se com espaços, dinâmicas e usuários de toda metrópole.

Desta observação ainda é possível estabelecer um outro paralelo, este entre como as diferentes visões sobre o Vale se relacionam com as datas de nascimento de seus autores. Enquanto aqueles autores que se baseiam na ideia de Parque para suas propostas são nascidos até meados dos anos de 1930 e, portanto, vivenciaram e conheceram o Anhangabaú ainda enquanto Jardim e Sala de Visitas, período pré-intervenções de Prestes Maia, aqueles que se basearam na ideia de Avenida Urbana são nascidos a partir da década de 1940, e, portanto, tem em suas primeiras memórias o Vale já em sua forma de artéria viária. A esta regra notamos apenas duas exceções: por um lado Jamil Kfouri, nascido em 1947, mas que compunha equipe com Jorge Wilheim (1928-2012) e Rosa Kliass (1932); e por outro Julio Katinsky, nascido em 1932, mas que compunha equipe com os arquitetos Marcos Acayaba (1944) e Edgar Dente (1945).

9 - Entendendo-se Dimensão Urbana dentro da proposta de LAMAS

10 - Entendendo-se Dimensão Territorial dentro do conceito de LAMAS 
Mas, se por um lado a data de nascimento explicaria as "atmosferas" que guiavam estes autores, seria o período de formação que melhor explicaria algumas das características projetivas das seis propostas.

A tomar a proposta de CA\&G, a única equipe liderada ainda por Engenheiros-Arquitetos ${ }^{11}$ dentre as propostas premiadas, notamos que há uma maior valorização dos aspectos funcionais em detrimento dos aspectos paisagísticos, urbanísticos e sociais se comparado com as demais propostas. Tal característica pode ser percebida pela forma como o desenho desta proposta acaba por se estruturar a partir do desenho dos sistemas viários e de transporte propostos. Não é o desejo por uma paisagem, parque ou jardim que imperam, mas antes, a necessidade de comportar os fluxos, as demandas e as exigências espaciais necessárias à cada sistema. São, assim como nas obras implantadas por estes arquitetos entre os anos de 1969 e 1970 na região da Praça da Bandeira e Avenida São João, avenidas, túneis, viadutos, passarelas e caminhos os verdadeiros parâmetros e elementos de desenho do Vale.

Como exemplos concretos desta relação, podemos destacar como os arquitetos destinam a ocupação de terrenos vagos para a construção de edifícios garagem, justificam a grande fenda em sua plataforma de pedestre sob o argumento de ventilação e aeração dos túneis subterrâneos, determinam a métrica construtiva a partir de módulos estruturais ideias, e, por fim, realizam o desenho dos caminhos para pedestres em função dos eixos e fluxos de circulação mapeáveis. O desenho e a leitura do próprio espaço, em suma, se constrói partir de e por meio de um processo estratificado, multi-camada, onde há a camada viária, a camada estrutural, a camada dos fluxos, a camada dos usos, etc.

É importante ressaltarmos, porém, que mais do influenciados pelos tecnicismos legítimos à Engenharia, algo que por si excluiria desta análise o arquiteto Gian Carlo Gasperini, estes arquitetos graduaram-se em um momento onde as principais teorias e práticas arquitetônicas baseavam-se na racionalidade técnica e funcional sustentada

11 - Plinio Croce graduou-se em 1946 na Faculdade de Engenharia Mackenzie. Roberto Aflalo graduou-se em 1950 na Faculdade de Arquitetura e Urbanismo Mackenzie, porém uma vez que o curso de Arquitetura seria criado apenas em 1947 os três primeiros anos de Aflalo foram cursados ainda dentro da Faculdade de Engenharia. Já Gian Carlo Gasperini graduou-se na Faculdade Nacional de Arquitetura do Rio de Janeiro em 1949. 


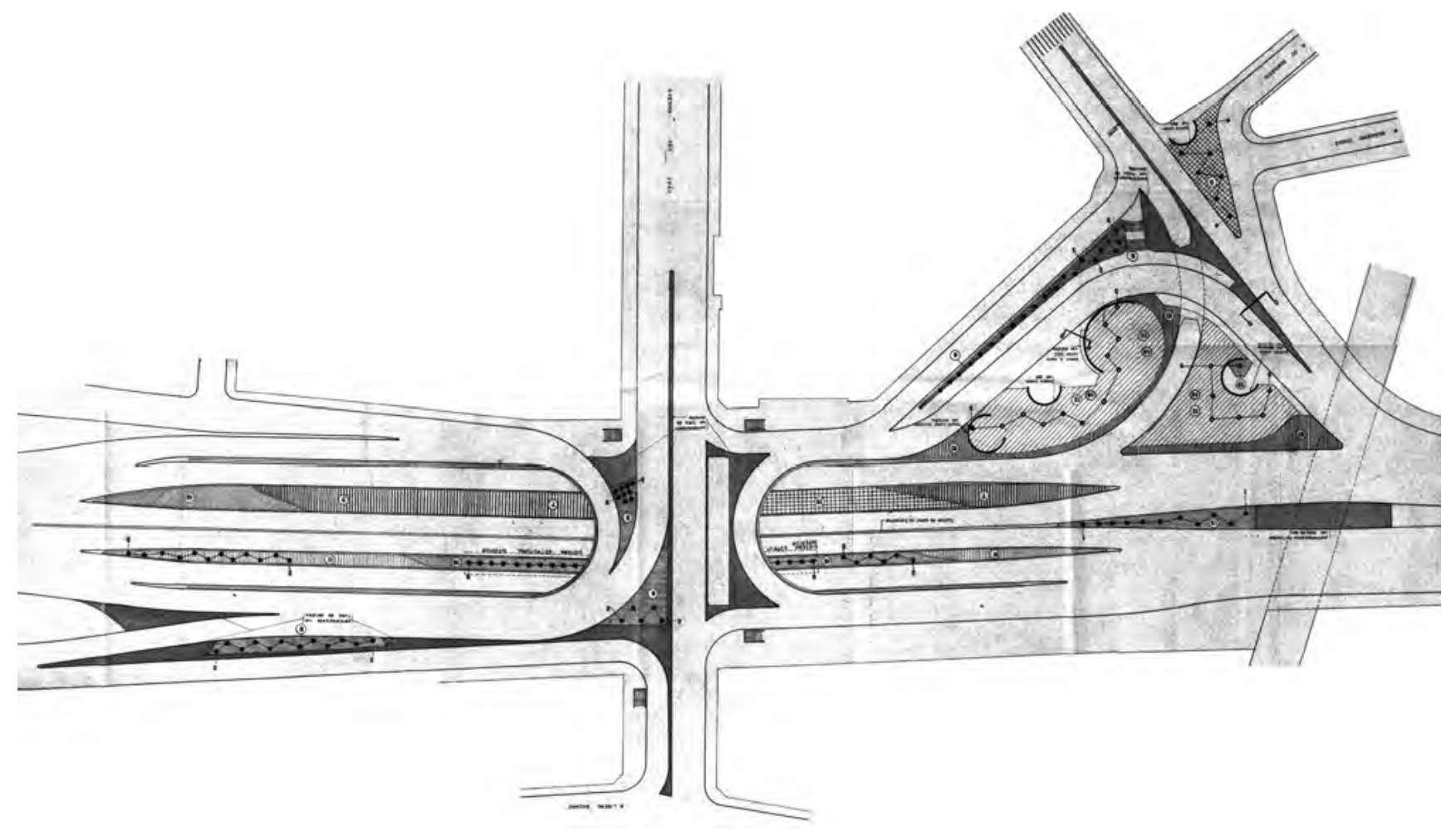

fig.93 Proposta de Croce, Aflalo e Gasperini para restruturação do encontro da avenida São João com Anhangabaú, 1970

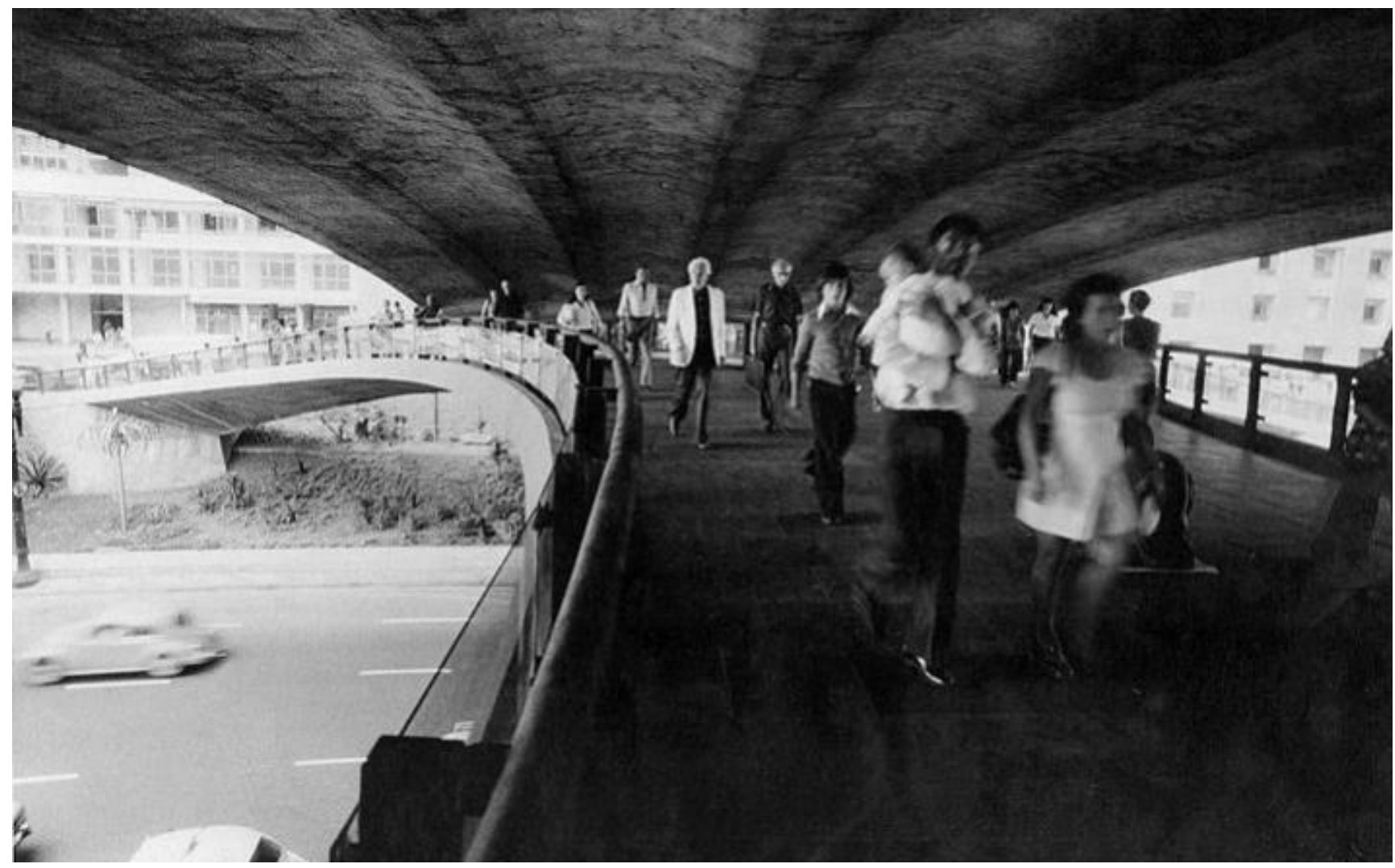

fig.94 Passarela sob o viaduto do chá, obra de Croce, Aflalo e Gasperini, por volta de 1970 - autor desconhecido

Reurbanização do Vale do Anhangabaú: propostas para recriação de uma paisagem 
pelos CIAM's. Como destacado por MUMFORD ${ }^{12}$, entre 1931 e 1939 os CIAM's estariam focados em discutir e desenvolver o tema da "Cidade Funcional", e entre 1939 e 1950 em difundir estas ideias nos Estados Unidos por meio da publicação em solo americano da Carta de Atenas.

Porém, se por um lado, a proposta de $C A \& G$ apresenta alguns traços compatíveis com as teorias e práticas urbanísticas da primeira metade do século $\mathrm{XX}$, não podemos deixar de notar também que, ainda que de forma discreta, o trabalho em questão apresenta algumas relações com teorias e práticas inauguradas a partir de 1950, sobretudo aquelas que defendiam a manutenção e valorização das "pré-existências" e do "caráter do lugar"13. Em outras palavras, apesar de partir de uma concepção majoritariamente funcionalista em nenhum momento de $C A \& G$ propõem a realização de uma terra arrasada que outrora vimos ocorrer em intervenções urbanas brasileiras dos anos 1960 e 1970.

Destacando os aspectos figurativos da proposta de CA\&G, notamos que estes autores optam por realizar uma relação à distância, para ser vista e percebida de forma mediada, por um cartão postal talvez, e não necessariamente vivida e presenciada em tempo presente. Visto como o grande gesto simbólico da proposta por seus autores, a fenda gravada na "placa" de Croce, Aflalo e Gasperini (CA\&G), apesar de resgatar à imagem (exagerada é verdade) do córrego original que deu nome ao Vale, dada à sua geometria, posição e lógica, colocava-se antes como um inibidor, um desestimulo, uma nova barreira ao uso do espaço criado do que um propriamente atrativo. Seria o ronco de um rio de carros tão aprazível quanto o farfalhar de um córrego? Seria esta a nova voz de São Paulo?

Por outro lado, partindo para a análise dos trabalhos de Wilheim, Kliass e Kfouri (WKK) e Bastos e Zanettini (BZ), ambos liderados por arquitetos formados em São Paulo ao longo dos anos $50^{14}$, notaremos não mais a influência dos conceitos funcionalistas da primeira metade do século XX, mas ao invés disso, a presença de abordaT 13 - MAYUMI, Lia. A Cidade Antiga nos CIAM, 1950-1959.

14 - Jorge Wilheim graduou-se me 1952 na Faculdade de Arquitetura Mackenzie. Rosa Kliass, Paulo Bastos, Siegbert Zanettini e Jamil Kfouri são todos graduados pela Faculdade de Arquitetura e Urbanismo da Universidade de São Paulo, respectivamente em 1955, 1959, 1959 e 1972. 
gens e práticas sustentadas por teorias que surgiriam a partir de 1950.

Começando pelas relatos e entrevistas concedidas por estes arquitetos à época, não podemos deixar de destacar o vocabulário empregado por estes autores para se referenciarem à suas propostas e ao próprio Concurso.

Para WKK o Concurso se resumiria, antes de mais nada, em dois pontos. O primeiro seria o fato do Concurso tratar-se de um Concurso de Desenho Urbano, uma vez que "não se tratava de urbanismo e tampouco de arquitetura" ${ }^{15}$. O segundo, seria o de resgatar o espaço do Vale como "core" da cidade de São Paulo" ${ }^{16}$. Já para BZ, o ponto central seria compreender o espaço do Vale como "coração da cidade"17, ponto de referência urbana, "lugar de tradição cívica, de encontro, de permanência, de passagem, de trabalho e de lazer"18

É de extrema importância destacarmos estas afirmações dos autores, uma vez que estas revelam não só a concepção dos espaços livres como algo a ser tratado por uma escala intermediária ao projeto arquitetônico e ao plano urbanístico, como também trazem à tona as referências teóricas que os orientavam. Por um lado, vemos os autores destacando a ideia norte-americana de Desenho Urbano, termo cunhado em 1956 no First Urban Design Conference, evento liderado por Josép Lluis Sert e que contou com a participação de figuras como Jane Jacobs, Edmund Bacon, Charles Abrams, Hideo Sassaki e Garret Eckbo. Como esclarece Krieger ${ }^{19}$, nesta conferência seus participantes pareciam concordar que a separação entre a "arte de construir" e a "sistematização do urbanismo" não contribuía com a construção novas cidades nem com a reconstrução daquelas destruídas pela Segunda Guerra. Ao invés disso, depositavam suas esperanças em uma nova disciplina dedicada ao desenho da cidade.

Por outro notamos a incorporação de conceitos cunhados na Europa a partir de 1951, notadamente nos CIAM VIII - O Coração da Cidade, também encabeçado por Sert, CIAM IX - A Carta da Habitação, o qual identifica-se com a ascenção da geração mais jovem, e CIAM X, encabeçado e pautado pelos questionamentos do grupo Team 10.

15 - KLIASS, Rosa in A Construção São Paulo, n. 1741 p. 05

16 - WILHEIM, Jorge. De espaço a lugar in Ver. Arquitetura e Urbanismo n42. São Paulo, jun-jul 1992

17 - BASTOS, PAULO in A Construção São Paulo, n. 1751 p. 16

18 - Item 6 do Memorial descritivo apresentado no concurso.

19 - KRIEGER, Alex \& SAUNDERS, William S.. Urban Design. University of Minessota Press. 2009 
Neste ponto, apoiando-se no trabalho de Marisol Rodrigues Sosa e Roberto Segres ${ }^{20}$, esclarecemos de forma sucinta algumas rupturas que ocorreram no plano teórico dos CIAM entre os anos de 1951 e 1956. Conforme os autores podemos destacar quatro pontos de ruptura:

\section{Separação funcional vs Escalas de organização comunitária}

Segundo SOSA \& SEGRES, é a partir do CIAM VIII que se abandona a grelha organizada a partir das funções estipuladas pela Carta de Atenas e se inicia a apresentação dos trabalhos com base nas Cinco Escalas de Organização Comunitária propostas pelo grupo MARS. Seria, entretanto, somente em 1952, durante os preparativos para o CIAM IX, que Bakema, Van Eyck, Van Ginkel, Hovens Greve, Peter Smithson e Voelcker produziriam o manifesto de Doorn, onde reiterariam a ideia de abordar o urbanismo a partir de comunidades de diferentes graus de complexidade - a casa, a rua, o bairro e a cidade.
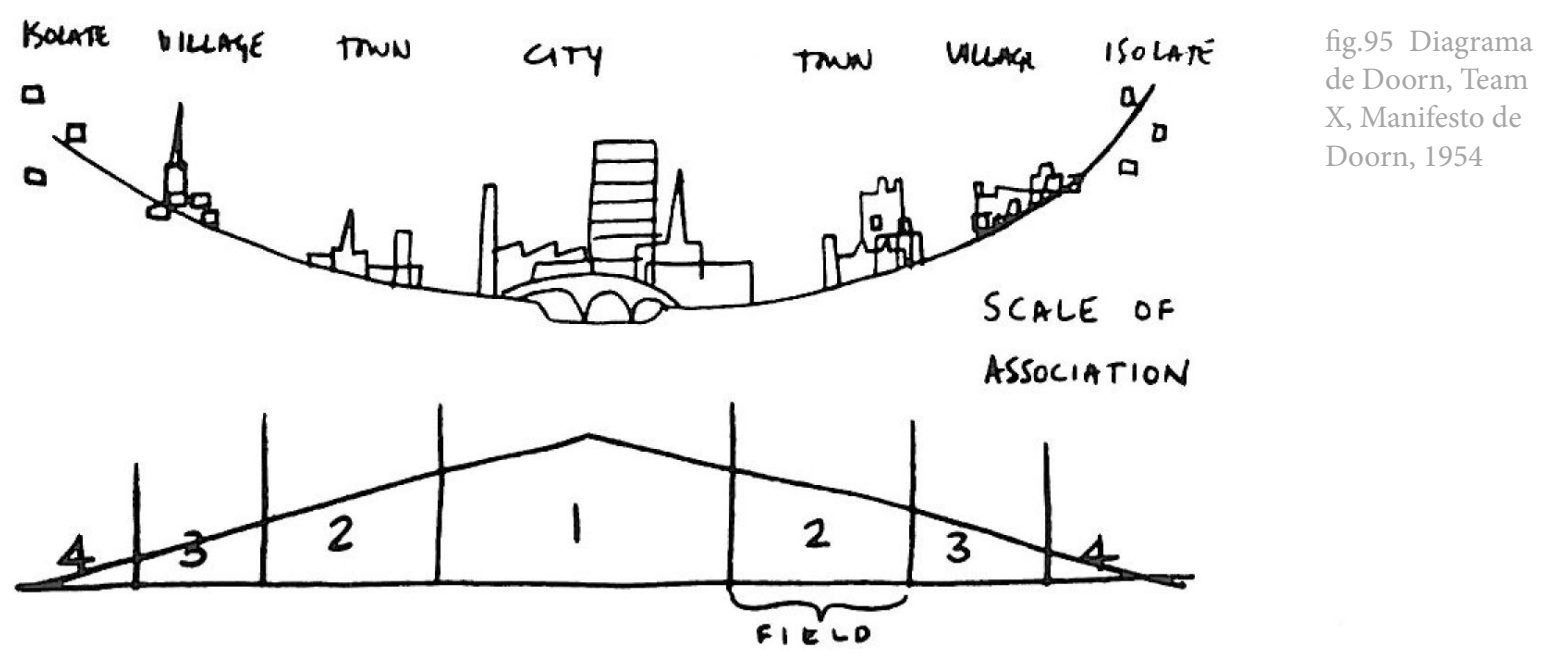

20 - SOSA, Marisol Rodrigues \& SEGRES, Roberto. Do Coração da Cidade a Otterlo (1951 - 1959): discussões transgressoras de ruptura, as sementes de novas direções pós CIAM. 2009 


\section{Centro Cívico vs Centro Comunitário}

Também é a partir do CIAM VIII que começou a se fazer mais palpável as diferenças de opiniões entre os mestres dos primeiros CIAM e a geração mais jovem sobre o núcleo das cidades. Enquanto aqueles defendiam a ideia de "grande centro cívico", espaço central da polis, os mais jovens estavam mais interessados na questão da comunidade e dos espaços públicos como lugares onde se davam as relações humanas. Em outras palavras, para a nova geração o foco da discussão não estava mais nas formas arquitetônicas e urbanísticas modernas que caracterizavam estes núcleos centrais, mas na análise desses espaços urbanos como lugar onde se processam as relações humanas, daí a importância dada às noções de comunidade e espaço público e humanização dos espaços urbanos.

\section{Quadra vs Rua}

Enquanto no debate da "Cidade Funcional" a solução do problema de habitação dependia da criação de protótipos geometricamente organizados sobre o território, criando conjuntos organizados e eficientes, para os jovens arquitetos a questão do habitat estava atrelada ao tratamento da comunidade e as relações humanas, assim como o reconhecimento das inter-relações entre as diferentes escalas na formação das comunidades. Nesse sentido, a noção de quadra como segunda escala de organização da cidade é substituída pela de rua, ou o espaço entre as formas construídas que organiza a vida urbana a partir da relação entre os moradores e o espaço. A terceira escala de organização seria, por sua vez, o bairro, o qual guardava a proporção territorial das comunidades urbanas. Dessa forma entre a escala da casa e da cidade, a rua e o bairro estabeleciam novas relações entre arquitetura e urbanismo, valorizando as inter-relações humanas com o espaço, assim como o reforço da identidade comunitária e do sentimento de pertencimento. 

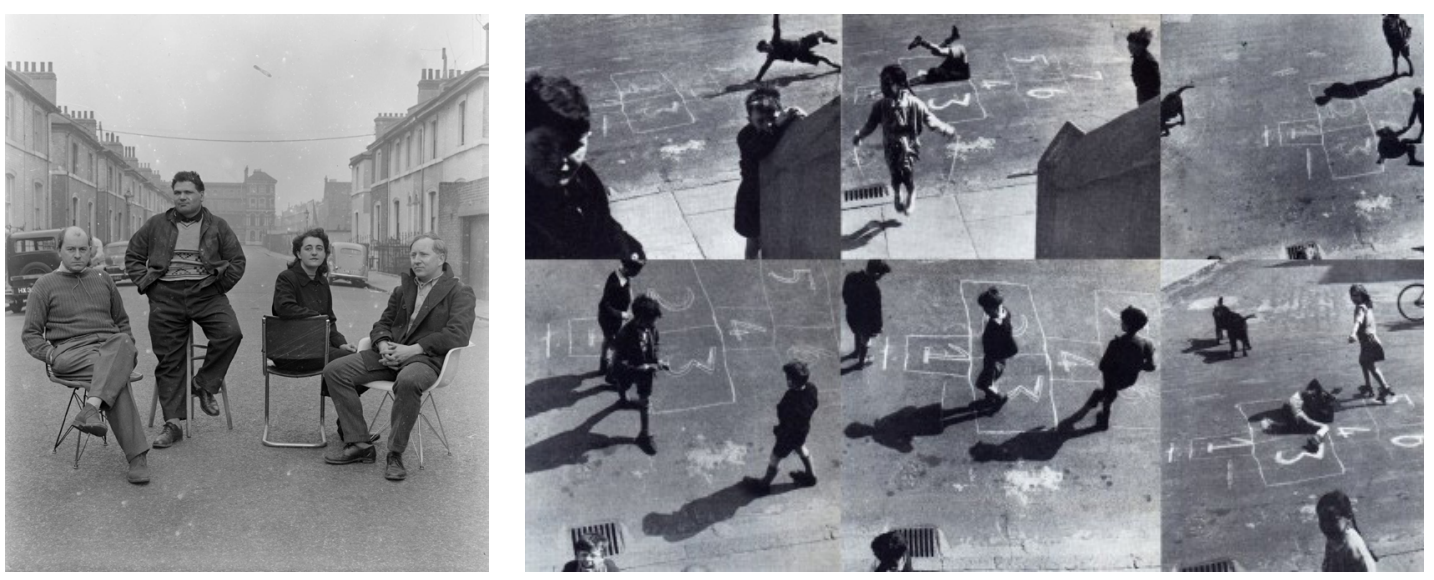

\section{Valores Funcionais vs Valores Culturais}

Com as discussões centradas em torno do tema do "núcleo urbano" a partir de 1951 surgiram também as discordâncias acerca dos valores que estes deveriam enfatizar e identificar. Como Richards coloca em sua sessão “The Humam Aspect of the Core", "o centro da cidade é o repositório da memória coletiva do grupo, o lugar onde reside a personalidade que distingue um lugar do outro". De fato, em 1956 no CIAM X, organizado pelo Team 10, as discussões se centrariam naqueles motivos pelos quais este grupo se criara, ou seja, na noção que o homem se organiza em comunidades e que por isso desenvolve a necessidade de se identificar, se identificar com o local que habita para criar vínculos sociais e apreender o espaço a partir de seus próprios valores culturais, de modo que o atributo essencial na relação homem-espaço era a constituição de lugares com identidade própria.

Voltando à análise das propostas de WKK e BZ, é possível identificarmos a presença destas abordagens baseadas nos aspectos comunitários também na maneira como estas equipes promovem a leitura, programação e ocupação do espaço do Vale.

Tomando a propostas de BZ notaremos, por exemplo, dois aspectos bastante correlacionados às práticas de arquitetos como Alisson e Peter Smithson no que diz respeito à leitura dos espaços. O primeiro reside na técnica e no enfoque do levantamento. Assim como era usualmente realizado pela dupla inglesa, BZ optaram por realizar o levantamento espacial do Vale não se baseando em suas estruturas físicas, tais como edifícios, viadutos, quarteirões, mas antes disso, nos usos e apropriações das áreas 
livres da região. Para tanto os autores utilizaram-se de um levantamento fotográfico realizado ao nível do chão que, destacadamente inserido na primeira prancha das três apresentadas, focaliza pessoas comuns relacionando-se em "cada viela, cada canto, cada piazzeta, cada esquina e cada rua". Neste levantamento os autores identificam também alguns elementos simbólicos que identificam o lugar, tais fachadas de edifícios, monumentos, bens tombados, mobiliários urbanos, etc.

Já o segundo aspecto nota-se na identificação de uma "estrutura espacial" particular e identificada com a região central de São Paulo, isto é, "uma sucessão crescente de espaços que vão da pequena largura de suas ruas, passando pelos alargamentos ocasionados pelas praças (Ramos de Azevedo, Patriarca Paysandu e São Bento) e culminam no espaço do Vale". Neste ponto os autores afirmam: "esses aspectos permitem uma leitura da história e forma de expansão da cidade, possibilitando ao cidadão, referenciar-se e identificar-se com seu espaço cotidiano"

É então a partir do cruzamento destas duas leituras os autores propõem, como em processo lógico, a ocupação do leito do Vale baseado em três momentos ou escalas de inter-relação entre seus usuários. A primeira, aproveitando-se das virtudes geográficas e simbólicas junto ao Viaduto do Chá, dedicar-se-ia as relações comunitárias mais abrangentes, ou seja, à ocorrência de eventos, reuniões e encontros excepcionais, de grande porte. Não por menos neste trecho os autores previram a realização de uma grande arena para eventos.

A segunda escala, igualmente aproveitando-se das condições pré-existentes, dedicar-se-ia ao suporte e acolhimento de relações pessoais mais intimas, realizadas individualmente ou em grupos pequenos. Neste trecho do Vale estariam dispostos, portanto, bancos, mesinhas, áreas sombreadas que conformariam assim uma área de estar.

A terceira escala, novamente aproveitando-se das condições locais verificadas, por sua vez dedicar-se ia às atividades de lazer e recreação, contando com a implantação de um playground, bancos, mesas de jogos e áreas sombreadas.

Um outro aspecto que podemos destacar da proposta de BZ que a difere enormemente das demais é o tratamento único que esta equipe deu aos circuitos e paradas de ônibus. Enquanto as demais equipes variam entre a distribuição em linha ao longo do Vale ou a criação de grandes terminais em suas cabeceiras (Terminal Bandeira e 
Terminal Pedro Lessa), BZ optam por não criar pontos específicos de destino, mas ao invés disso, criam um anel de contorno do centro que possibilita a distribuição pulverizada das paradas e com isso aproximando-as de seus usuários. Não é a lógica e a eficiência do sistema técnico que imperam, mas mais uma vez, as necessidades e as relações humanas que prevalecem.

Neste sentido é interessante notarmos que são exatamente estas relações humanas que são colocadas como a imagem síntese e monumento do Vale pretendido. Não por menos, ao observarmos as perspectivas e a planta de situação apresentada notaremos que o foco, o ponto central, dos desenhos encontra-se precisamente na arena de eventos, espaço mais simbólico e potente do ponto de vista das relações urbanas.

Passando para o projeto de WKK, apesar de mantida a mesma estrutura de levantamento (ida à campo, identificação in loco, reconhecimento presencial), notamos, entretanto, uma significativa mudança no enfoque dado. Como vimos anteriormente, enquanto BZ dedicaram-se a reconhecer as inter-relações humanas e a estrutura do lugar da região central, WKK, a partir do material levantado, dedicaram-se à identificação de problemas de ordem funcional e sistêmica presentes no Vale. Como descreve Rosa Kliass ${ }^{21}$ :

"os oito arquitetos que trabalharam no projeto partiram para a conferência de dados miúdos, como a verificação real das cotas, constatação do número e itinerários de ônibus, volume de tráfego e seus picos, correta disposição e situação as interferências existentes, etc. Não tínhamos nenhuma ideia preconcebida, mas esta começou a ser desenvolvida à medida em que analisávamos a situação verdadeira do Vale do Anhangabaú através de informações atualizadas".

Porém, se por um lado vemos enfoques tão distintos em seus levantamentos e leituras da região, não podemos deixar de notar que a proposta de ocupação defendida por WKK é muito semelhante, para não dizer idêntica, à proposta por BZ. Assim com a proposta terceira colocada, WKK propõem uma ocupação baseada na criação de espaços capazes de acolher e potencializar as inter-relações humanas de diversas escalas, sendo o primeiro dedicado à grandes eventos e comunidades alargadas

21 - Rosa Kliass in A Construção São Paulo, n. 1741 p.04 


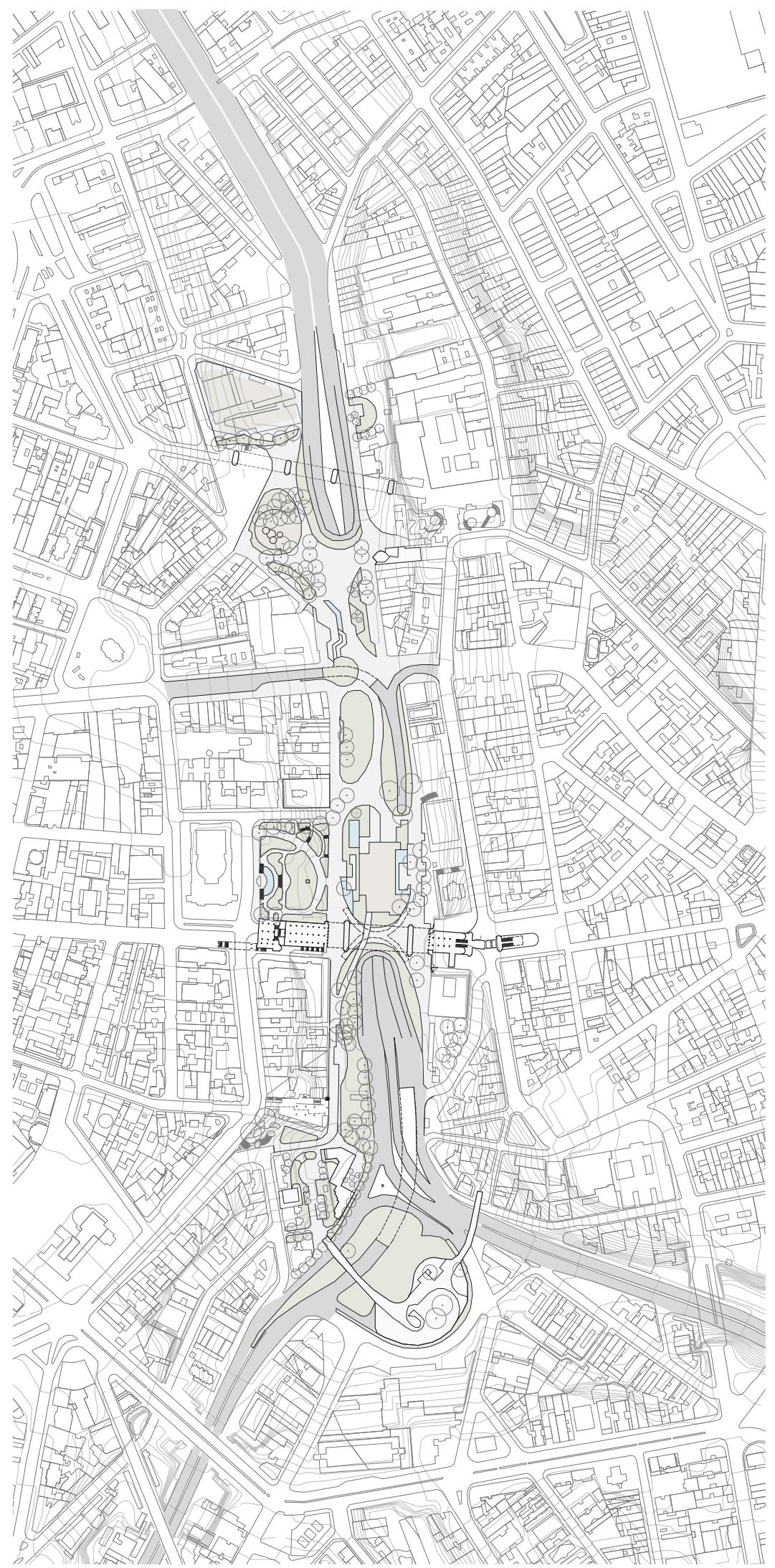

fig.97 Redesenho da propota de Jorge Wilheim, Rosa Kliass e Jamil Kfouri - Acervo do Autor
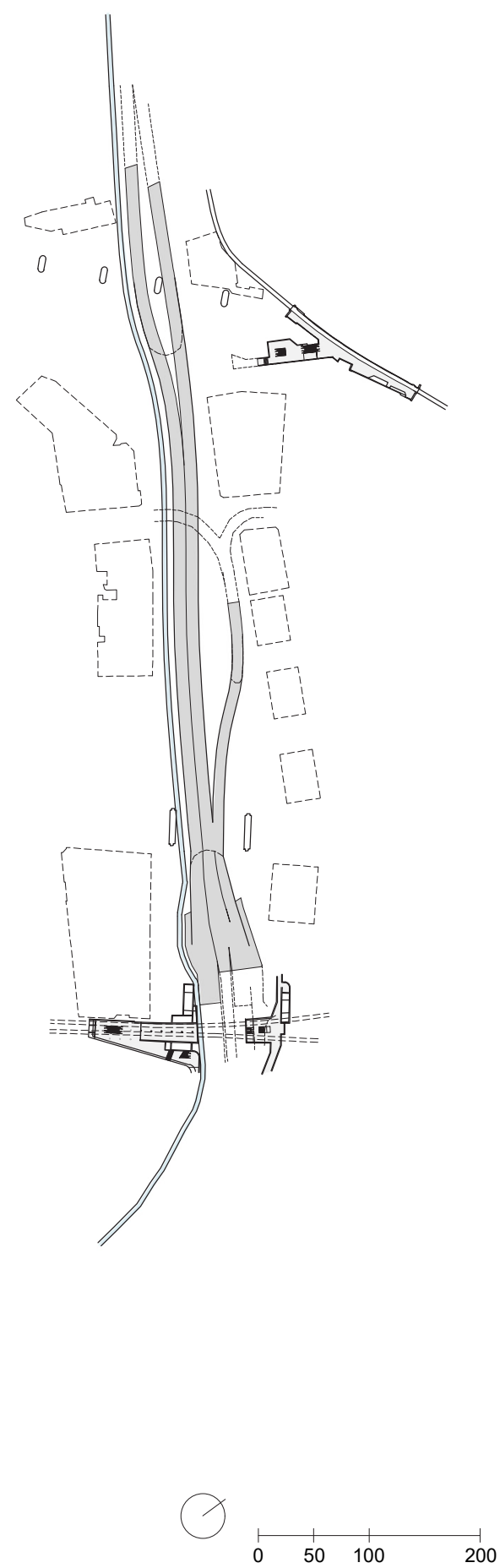


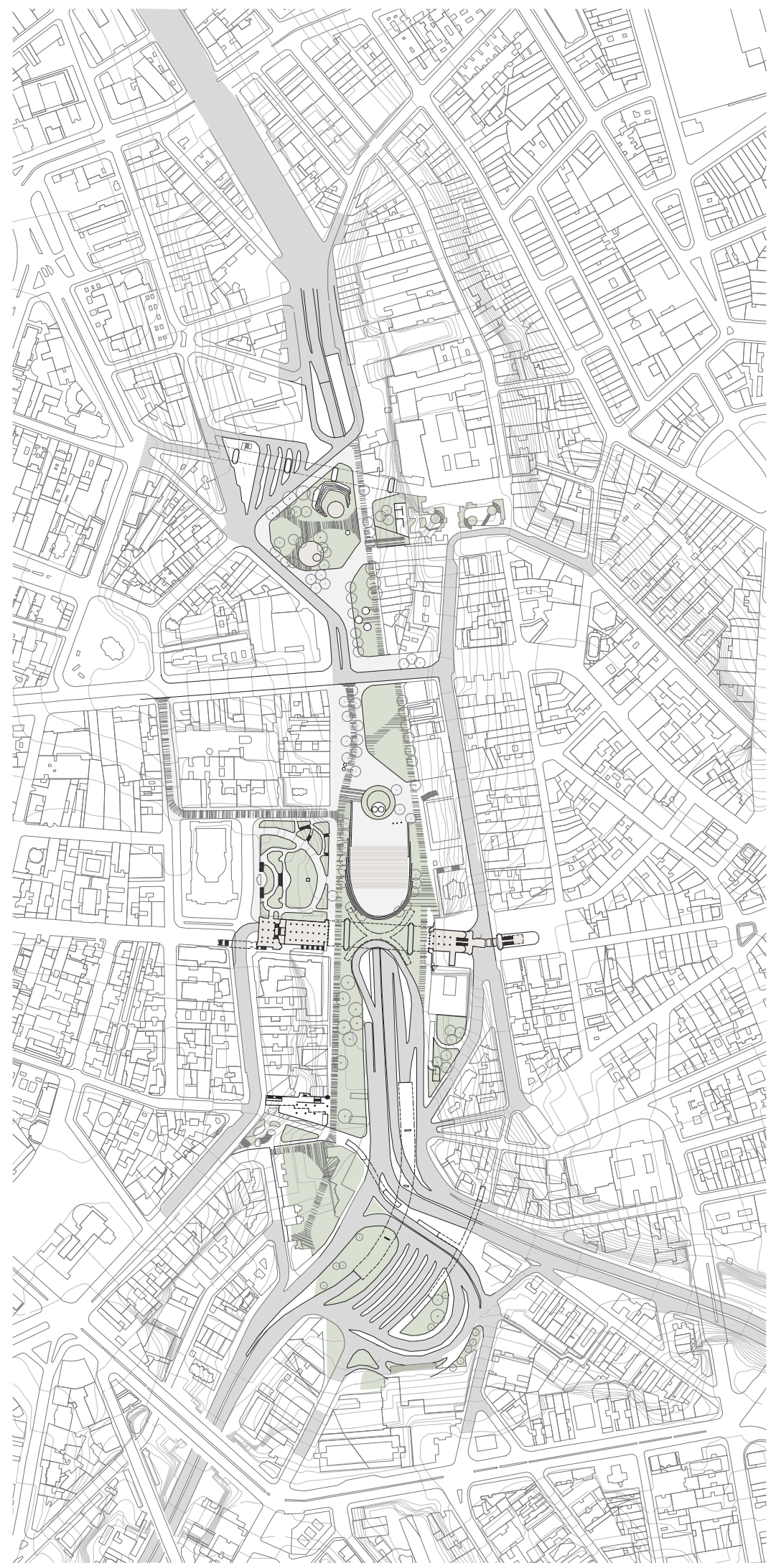

fig.98 Redesenho da propota de Siegbert Zanettini e Paulo BAstos Acervo do Autor

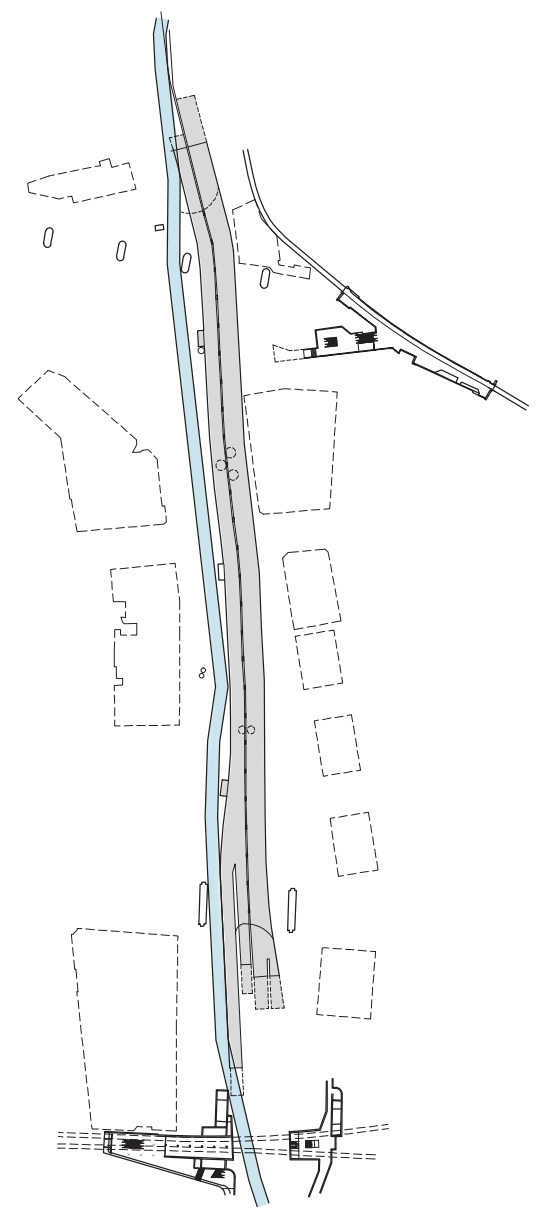

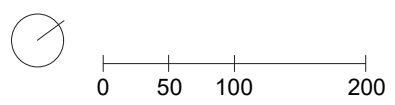


(arena), o segundo dedicado aos usos individuais e em pequenos grupos (estar) e o terceiro às atividades de lazer e recreação (playground). Não podemos deixar de notar também que mais do que os mesmos programas ambas as equipes se utilizaram dos mesmos locais para a suas implantações.

Neste ponto, sendo esta semelhança simples coincidência ou não, é importante fazermos aqui algumas considerações. Em primeiro lugar devemos nos questionar o quanto de fato estes autores utilizaram-se dos levantamentos realizados nos meses anteriores à entrega do concurso para formularem suas propostas e o quanto esses não se tornaram recursos de uma retórica própria para o Concurso? Em outras palavras, o quanto havia nestas propostas desenvolvidas em pouco mais de 60 dias de fato de conceituação e o quanto havia de pré-conceituação? Seria o Concurso um espaço para a realização de pesquisas e reflexões ou, antes disso, um espaço para justificativas e respostas?

Analisando os aspectos qualitativos desta proposta, destacamos como WKK, dentre todos os demais autores, são aqueles que buscam abordar de forma mais consistente as três escalas de relação propostas por LAMAS. Podemos fazer esta afirmação baseados tanto no detalhamento apresentado nas plantas da proposta quanto pela apresentação de perspectivas que são capazes de ilustras as relações de dimensão territorial, urbana e setorial.

Do ponto de vista da escala territorial, a equipe utiliza-se de uma perspectiva ao nível dos olhos realizada a partir da Praça da Bandeira e focalizando o Vale ao fundo. Com este ponto de vista único a equipe deixa claro sua intenção em fazer presente a paisagem do Vale não somente para aqueles que estão dentro dele, seus usuários de fato, ou por imagens que a reproduzam, mas também para aqueles se encontram a distância e que apesar de não a compreenderem totalmente podem intuí-la. Infelizmente, dado ao abandono desta parte do projeto e a realização de uma nova passarela bem em meio ao eixo do Vale não podemos saber se tal relação se concretizaria ou não.

Quanto à escala urbana, podemos destacar a perspectiva realizada à cavaleira focando o trecho junto ao pontilhão da Avenida São João. Nesta perspectiva os autores sugerem a utilização como uma promenade, uma rota alternativa tanto para os deslocamentos transversais quanto longitudinais cotidianos de seus usuários. Nesta imagem 
surge também a relação com as edificações vizinhas, os alargamentos e praças criados para acomodação das atividades pré-existentes na região.

Por fim, no que diz respeito à dimensão setorial ${ }^{22}$, novamente notamos um ponto de observação único em uma das perspectivas apresentadas por esta equipe, retratando o Vale não mais em seu sentido longitudinal ou obliquo, mas totalmente transversal ao seu eixo e com um enquadramento fechado. Aqui notamos que a eleição deste ângulo revela um ato projetivo, a identificação de potencialidades e oportunidades: neste caso a relação entre as encostas e a utilização dos jardins da praça Ramos de Azevedo como arquibancada natural (ou pano de fundo como aconteceria com o desenvolvimento do projeto) para a criação da "grande praça de eventos". Cabe aqui lembrarmos que desde o projeto desenvolvido por Bouvard em 1911 não havia uma proposta para o Vale onde as visuais transversais assumiam tamanho protagonismo, como se os trechos do vale compusessem, isoladamente, momentos específicos em meio à paisagem da cidade. Se no caso de Bouvard esta ideia se materializava pela criação dos terraços gêmeos dos Edifícios Prates, no caso de WKK, tal percepção de pequenas unidades paisagística seria reforçado, anos mais tarde, pelo desenvolvimento do desenho de piso ondulante e pelo posicionamento dos maciços-arquibancadas, bancos e belvedere da São João.

Mas se por um lado estes arquitetos identificariam estas oportunidades paisagísticas transversais, caso verificado na praça de eventos e na fonte que surgiria no eixo da Avenida São João, não podemos deixar de notar que tais paisagens continuam ocultas para a grande maioria da população. Não por menos, apesar do sentido proposto em projeto para a realização de eventos no Vale ser transversal a ele (tribuna com Teatro Municipal ao fundo, arquibancadas de frente) desde 1981, a maioria dos eventos que ocorrem no Vale são realizado na outra direção, posicionando o palco sob o Viaduto do Chá ou em oposição a ele e concentrando a população ao longo da curva descrita entre os jardins.

Um fato que talvez possa explicar o maior domínio escalar desta equipe em relação às demais seja que esta era a única entre as equipes premiadas que contava com a participação efetiva de arquitetos-paisagistas, destacadamente liderados pela figura 22 - Conforme Lamas (1993), dimensão setorial é "a mais pequena unidade ou porção do espaço urbano, com forma própria. Uma inifinidade de elementos que organizados entre si, definema forma urbana (edifícios, o traçado, estrutura verde, mobiliário urbano). 


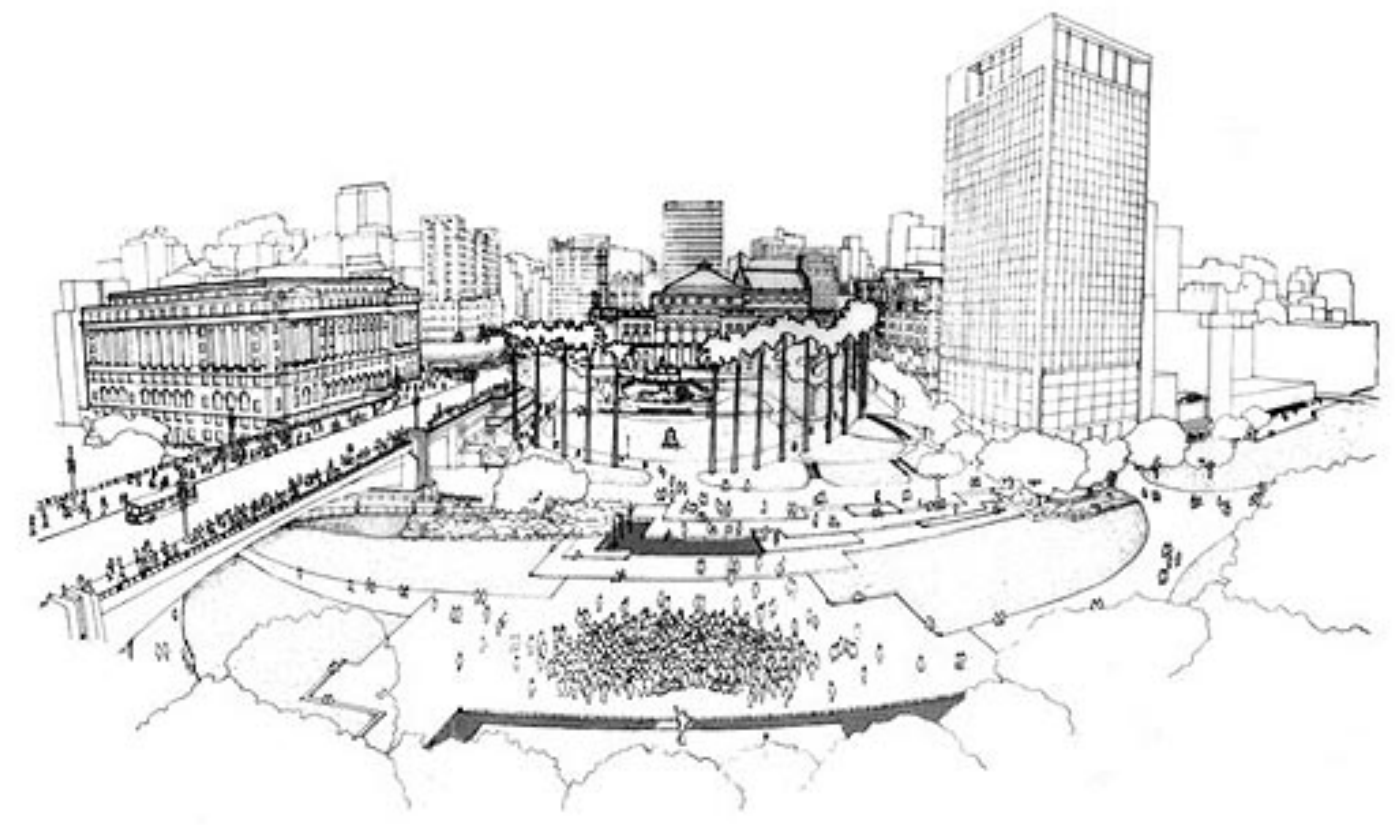

fig.100 Perspectiva do Vale do Anhnagabaú, prancha entregue ao concurso - retirado do site http://www. jorgewilheim.com. br/legado/Projeto/ visualizar/1835 em 04/07/2016

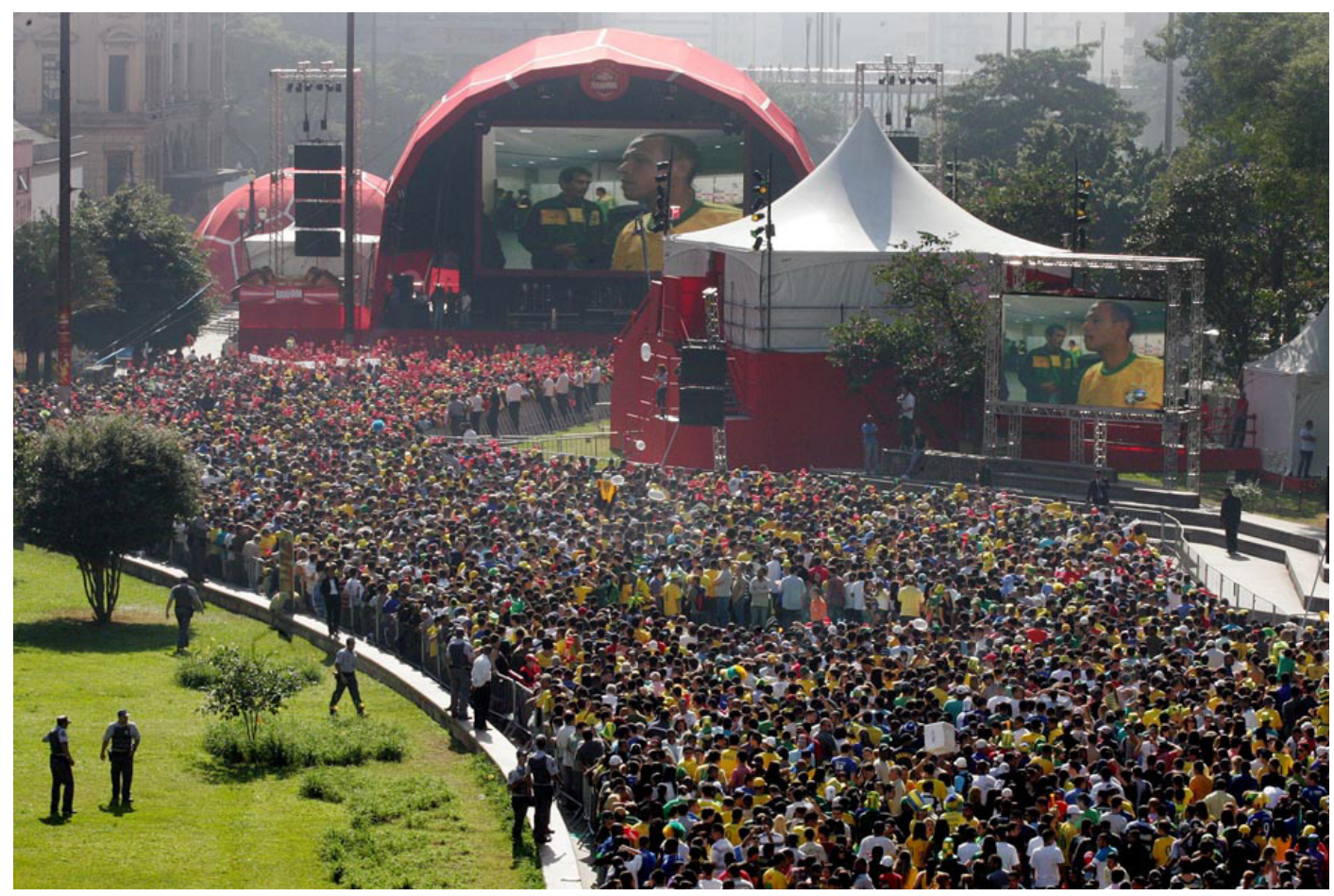

fig.101 Fan Fest realizada durante a Copa do Mundo de Futebol de 2010

fig.99 FIGURA

Reurbanização do Vale do Anhangabaú: propostas para recriação de uma paisagem 
de Rosa Kliass que à época já contava com mais de vinte e cinco anos de experiência neste tipo de projeto. Neste ponto é necessário constatarmos um índice preocupante: dentre os dezoito autores premiados pelo concurso apenas Rosa Kliass e Jamil Kfouri dedicavam-se ao paisagismo como atividade principal, ou seja apenas $11 \%$ do total dos arquitetos.

Para além da identificação destas oportunidades paisagísticas transversais ao Vale, cabe aqui também destacarmos algumas considerações acerca da arquitetura-paisagística proposta por WKK. Concebida sobretudo pela figura de Rosa Kliass e "de maneira a sempre lembrar um jardim"23, a proposta organiza-se em torno de um eixo longitudinal de articulação, que desenhado de forma sinuosa, rompe com a simetria a define alguns alargamentos ao longo do Vale. Neste ponto, segundo Macedo ${ }^{24}$, é possível identificar a influência de Roberto Cardozo, paisagista californiano que por indicação de Garret Eckbo seria convidado por Vilanova Artigas em 1954 para assumir a disciplina de Arquitetura-Paisagística, tornando-se, portanto, professor de Rosa Kliass no ano de 1955.

Um outro ponto onde podemos estabelecer paralelos entre a arquitetura-paisagística californiana e a proposta por WKK é na exploração da geometria, na composição e nos usos de materiais. Neste ponto destacamos as proximidades entre a proposta para o Vale do Anhangabaú e algumas proposta de Lawrence Halprin, destacadamente a Lovejoy Plaza e Ira Keller Fountain, ambas situadas na cidade americana de Portland e inauguradas respectivamente em 1966 e 1970.

Mas se dentro destas obras de Halprin para a cidade de Portland identificamos, segundo Martins ${ }^{25}$, a concretização de "uma experiência sensorial, emocional e sinestésica, especialmente pelo uso da água, tanto como elemento unificador da "ecologia" da paisagem, quanto pela maneira como interage com a tectônica das formas e estimula os sentidos simultaneamente", na proposta de WKK, ao considerarmos a qualidade estática dada a este elemento junto à grande praça de eventos, tornando-o antes um delimitador de espaços do que um ativador sinestésico, podemos dizer que as influências se dão muito mais do ponto de vista formal do que propriamente

23 - Rosa Kliass in A Construção São Paulo, n. 1741 p.06

24 - Comentário concedido por Silvio Macedo durante a banca de qualificação deste trabalho 25 - MARTINS, Talita Rocha. Lawrence Halprin: Contribuições para uma prática compreensiva na arquitetura da paisagem. São Paulo: FAUUSP, 2014 
conceitual.

Dentro desta análise, mesmo se considerarmos as duas fontes dinâmicas criadas ao longo dos dez anos que correram entre o Concurso e a conclusão das obras, uma localizada no eixo da Avenida São João aproveitando-se da abdicação da construção do pontilhão e outra entre a praça do correio e estação São Bento do Metrô, notaremos que, dado o distanciamento imposto pelos desníveis e jardins, a água persiste ainda antes como um elemento de ordenamento espacial e contemplação visual do que campo para experiências "sinestésicas" propostas por Halprin.

Acerca desta fonte criada no eixo da Avenida São João, cabe lembrarmos que esta surgira de forma imprevista, dado que a eliminação do pontilhão previsto no Concurso só ocorreria em 1990 e, portanto, as vésperas de inauguração do complexo do Vale. Neste sentido é importante destacarmos como algumas verdades técnicas colocadas à época do Concurso, com o passar dos anos, vieram por se tornar verdade históricas e, portanto, passíveis de questionamento e superação. No caso específico do pontilhão observamos que a verdade técnica superada foi a própria inquestionabilidade da conexão Sul-Oeste, porém se considerarmos todo o processo do Concurso notaremos também a superação de questões como 1) a incapacidade financeira do Estado em arcar com obras deste porte; 2) a inviabilidade técnica de se mexer no subsolo do Vale; 3) a identificação de um modelo único e ideal de transporte; 4) a incapacidade de arquitetos coordenarem equipes multidisciplinares em obras deste gênero; 5) o desleixo do Estado com a qualidade dos espaços públicos, etc. 


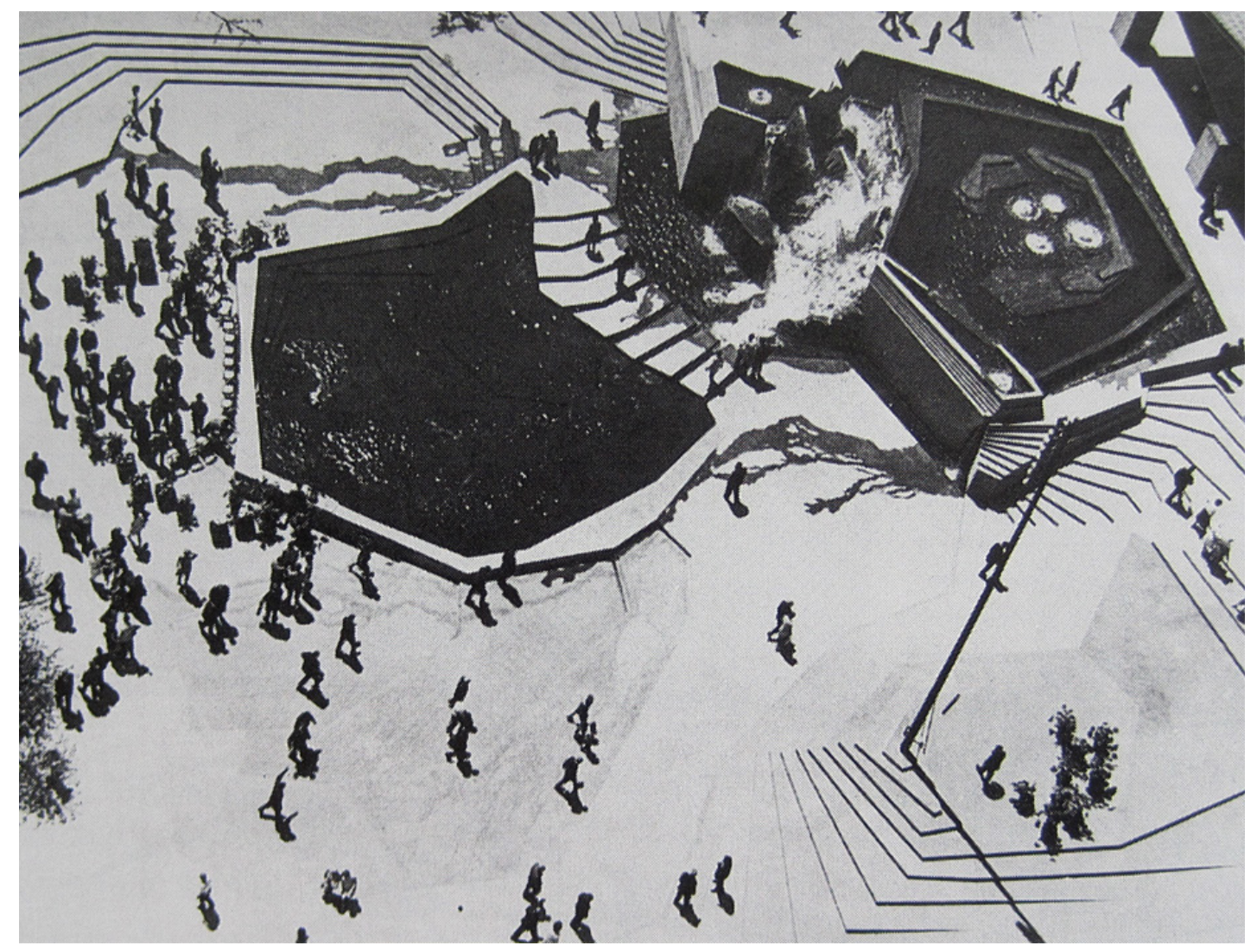

fig.102 Lovejay

ountain Park,La-

wrence Halprin,

1966

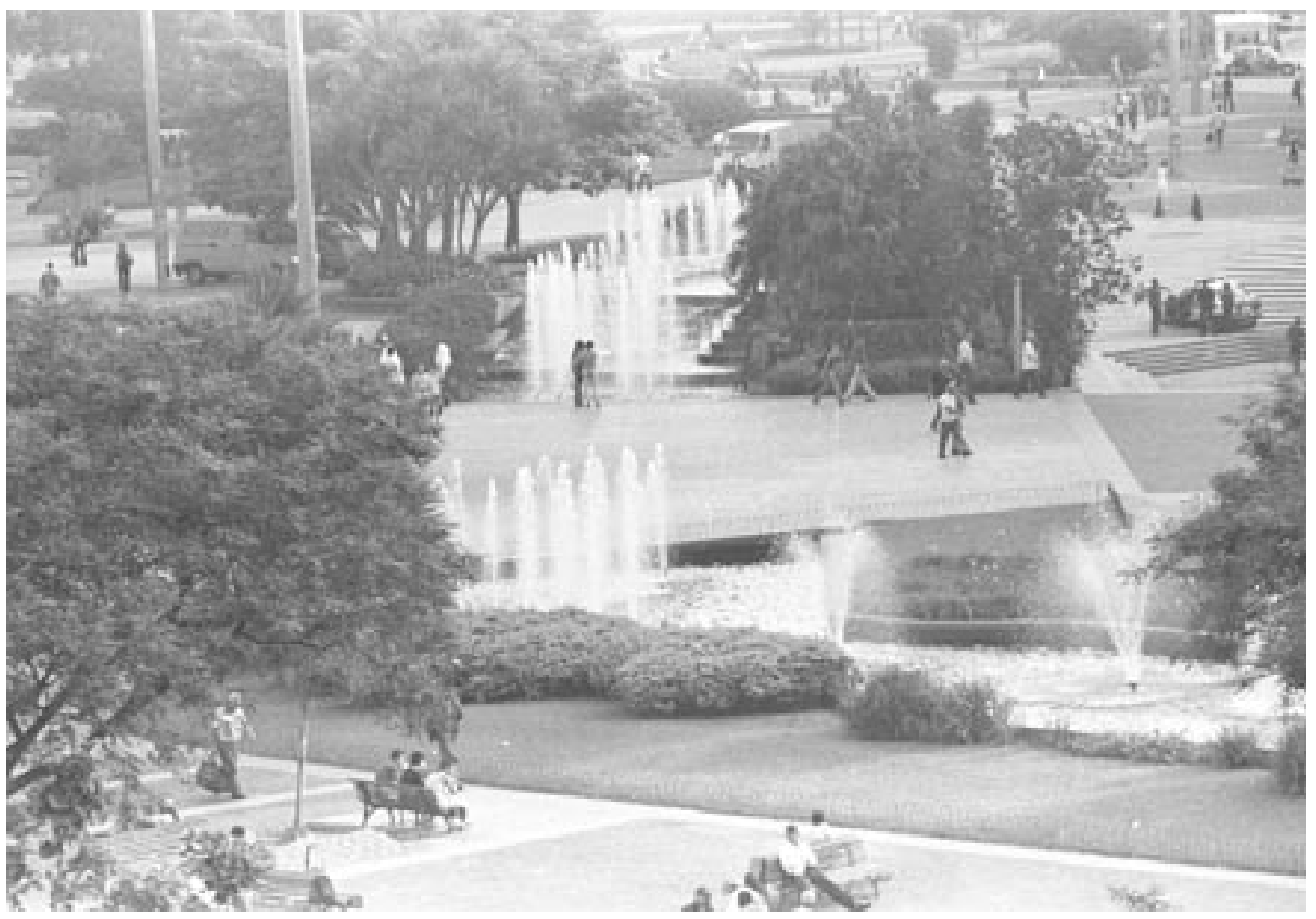

fig.103 Fonte Vale do Anhangabaú, Kliass e Kfouri, 1991 
Passando para a análise da proposta de EG, novamente podemos notar algumas rupturas em relação as demais equipes na maneira de conceber os aspectos funcionais dentro de sua proposta. Desta vez, porém, como demonstraremos a seguir, observa-se um salto temporal ainda maior do que aquele entre as propostas de CA\&G e WKK e BZ.

Antes de mais nada é preciso destacarmos aqui a conformação desta equipe "sui generis" conforme a descreve o próprio Gomes ${ }^{26}$. Diferentemente das demais equipes esta contaria em seus quadros com apenas dois arquitetos já formados, sedo um o próprio e Elgson Gomes, graduado em Engenharia Civil na UFPR em 1945 e em Arquitetura e Urbanismo pelo Mackenzie em 1958, e sua filha Maria Luiza Gomes, formada em 1979 pela UFPR. Todos os outros seis membros eram à época ainda quarto anistas do curso de Arquitetura da UFPR. Outra peculiaridade que esta equipe apresenta em relação as demais é o fato de seus membros não terem nascido e vivido em São Paulo, com a exceção de Elgson que nascido no interior de Santa Catarina residiu na capital paulista entre os anos de 1953 e 1958, período que cursou Arquitetura no Mackenzie e trabalhou nos em alguns escritórios paulistanos, entre eles o de Franz Heep que à época se situava próximo ao Vale.

No que diz respeito às intervenções propostas pela equipe de EG, notamos um movimento que oscila entre uma visão mais próxima das concepções de "Cidade Funcional” pré 1950, uma visão futurista de cidade difundida no final dos anos 70 e início dos 80 por filmes de grande sucesso, tais como Star Wars IV - Uma Nova Esperança (1977), Star Wars V - O Império Contra-ataca (1980) e Blade Runner, o Caçador de Androides (1982) e um desejo latente pela restituição da natureza perdida à paisagem paulistana.

Do ponto de vista projetivo, tal oscilação pode ser percebida sobretudo na maneira como EG sugere a ocupação dos espaços livres do leito do Vale e pelas proposições que faz acerca do uso da tecnologia, notadamente em sua aplicação nos meios de transporte e locomoção presentes no Vale.

Iniciando pelos usos e ocupações do solo, notamos que há por parte desta equi-

26 - Elgson Ribeiro Gomes in A Construção São Paulo, n 1745 p. 12 
pe, semelhantemente ao que vimos em $C A \& G$, a valorização dos aspectos viários e funcionais sobre as questões de relação comunitária e inter-pessoal. Neste ponto destacamos como a equipe utiliza-se de uma lógica de travessia para pedestres muito semelhante à elaborada pela EMURB, isto é, apoiada sobre os fluxos calculadamente tidos como mais eficientes, tornando esta questão antes uma equação sistêmica, uma travessia, do que uma questão de fruição, um passeio.

Outro ponto a se destacar é quanto à ocupação das áreas centrais do vale, mais propriamente do trecho compreendido entre Viaduto do Chá e Avenida São João. Enquanto vimos em WKK e BZ a preocupação de realizar diferentes espacialidades a fim de abrigar e potencializar as mais variadas formas de encontros humanos, em EG, apesar de em seu memorial o arquiteto mencionar a intenção de "propiciar a realização de encontros e eventos distintos”, notaremos a ocupação de extensas áreas por bosques e fontes, remanescendo aos usuários pequenas parcelas de solo, quase sempre desenhadas à maneira de caminhos. Conforme explica EG a criação destes bosques e fontes tinham como objetivo central realizar "o retorno, ao centro de São Paulo, da natureza original" e possibilitar "a participação do verde no dia a dia do paulistano"27.

A este "ecologismo" que observamos nas palavras de Elgson Gomes podemos fazer algumas considerações. Primeiro é importante lembrarmos que este autor nascera e criara-se em cidades pequenas do interior do sul do Brasil, até que em 1939, aos quinze anos de idade, saiu de Porto Amazonas-PR e mudou-se para Curitiba para cursar o ensino médio. Conforme relato de seu filho Péricles Varella Gomes, este seria um dos motivos pelos quais Elgson mantinha tanta proximidade e o gosto pela "natureza".

Mas se por um lado a experiência de vida do autor explica em parte sua abordagem "ecológica", por outro não podemos deixar destacar a influência do pensamento internacional da época. Fato é que desde meados dos anos 70 Gomes participava das reuniões da União Internacional do Arquitetos (UIA), as quais eram realizadas a cada biênio e abordavam temas referentes à Arquitetura e ao Urbanismo da época. É de se notar, portanto, que em 1981, ano de realização do Concurso, a partir do seminário intitulado Man - Architecture - The Enviroment a UIA publicaria a Decla-

27 - Elgson Ribeiro Gomes in A Construção São Paulo, n. 1745 p. 12 
fig.106 Cena do filme Star Wars IV - Uma Nova esperança 1977 fig.107 Cena do filme Star Wars V - O Império

Contra-ataca 1980

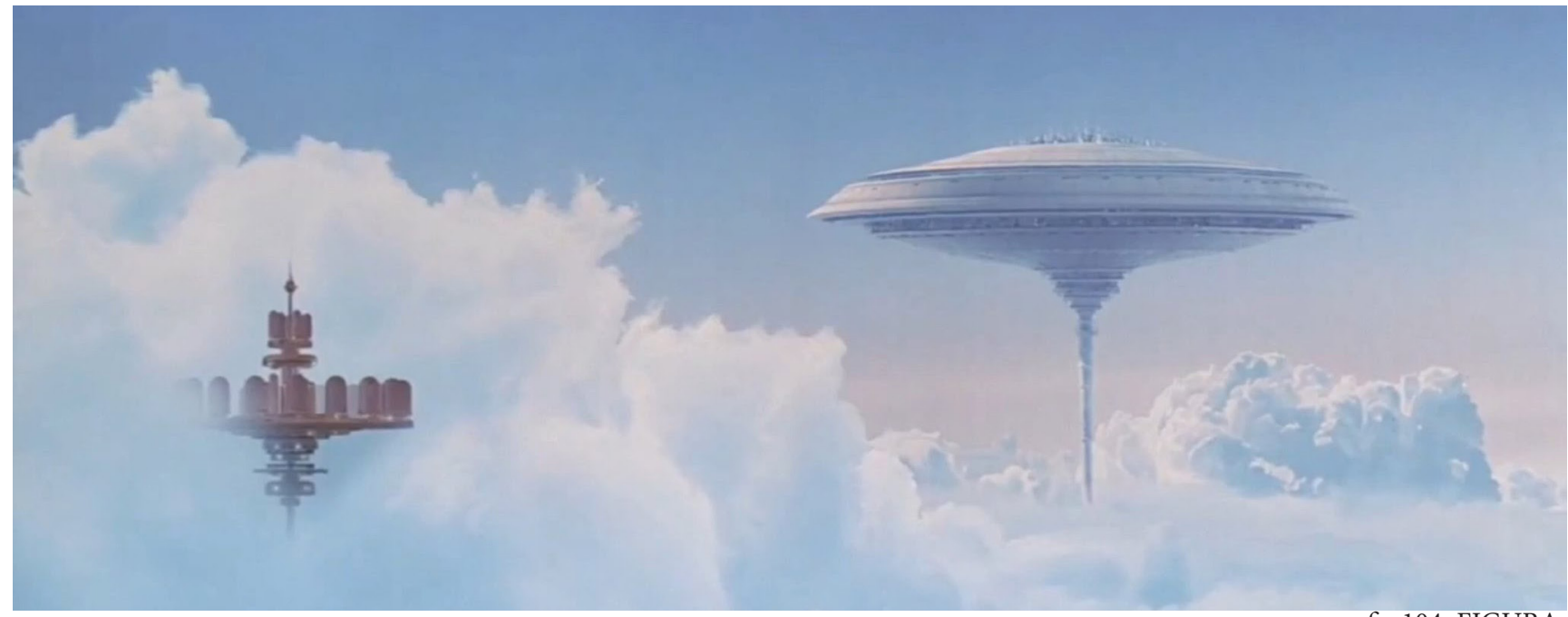

fig.104 FIGURA

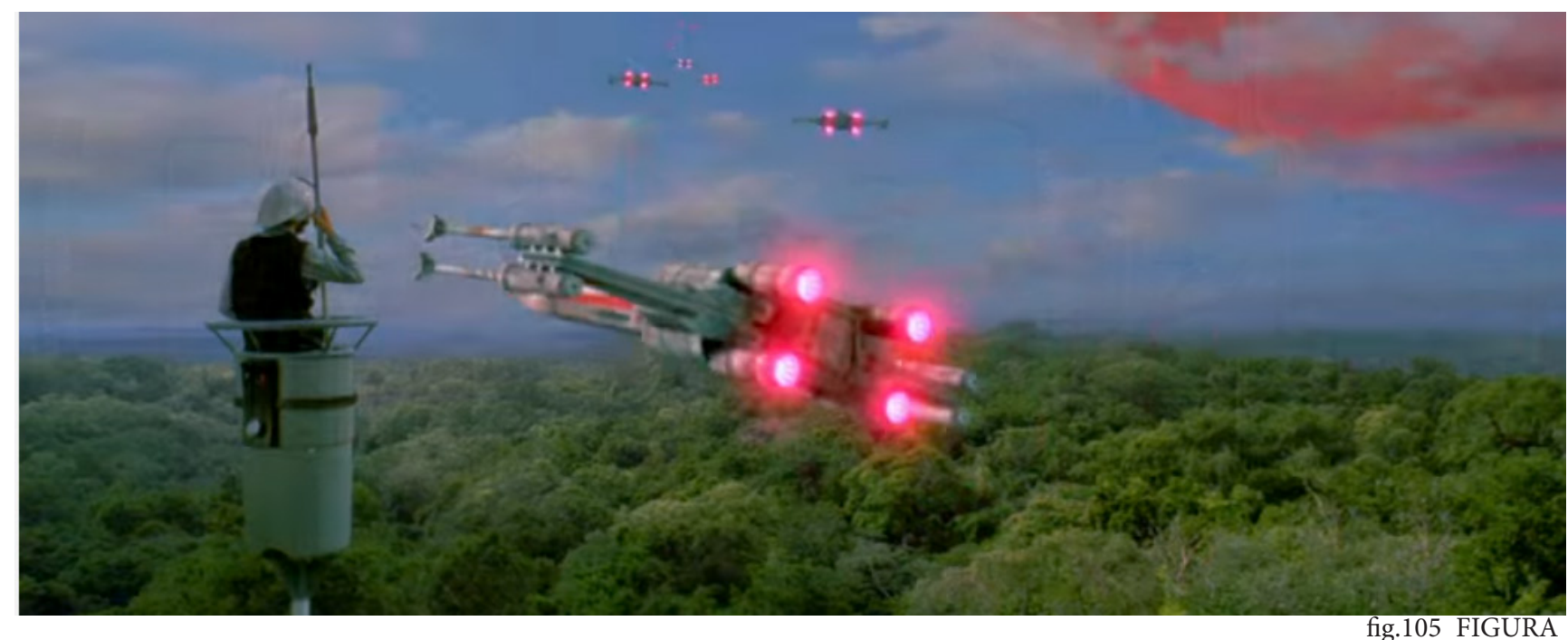

Reurbanização do Vale do Anhangabaú: propostas para recriação de uma paisagem 

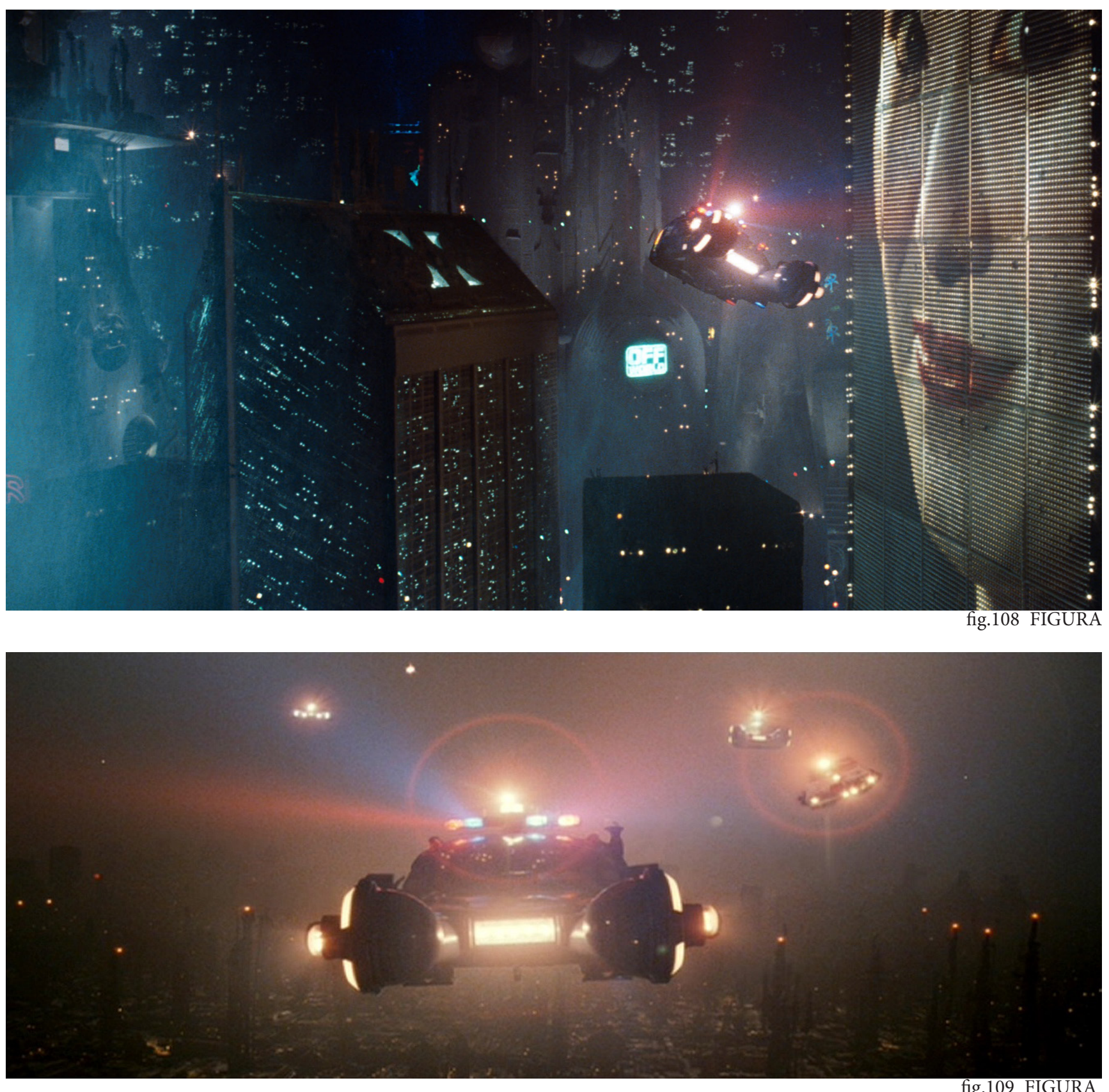
ração de Varsóvia dos Arquitetos, o qual destacamos as seguintes considerações feitas acerca do urbanismo da época:

- Apresenta desenvolvimento antropocentrista da terra, destruindo assim o equilíbrio da Natureza

- Realiza a inserção funcional da Natureza, não participativa nos aspectos emocionais das cidades e dos assentamentos humanos

E em sua continuação o documento ainda realiza a seguinte recomendação para os Arquitetos e Urbanistas:

- A Natureza deve dar maior valor aos assentamentos humanos, assim como estes devem também dar maior valor à Natureza: há continuidade de significado entre o Homem e a Natureza

A respeito da apropriação destes conceitos, é de se destacar como, do ponto de vista figurativo, Elgson parece sugerir que o Vale do Anhangabaú se torne uma espécie de repositório da Natureza original de São Paulo, dispensando as atividades e as estruturas comunitária da construção de sua paisagem. Enquanto nas demais equipes ao olharmos para o Vale identificaríamos praças, arenas, escadarias, arquibancadas, áreas recreativas, monumentos e vegetação ordenada, na proposta de Elgson identificaríamos o leito do Vale como uma terra naturalizada, quase intacta, uma memória da imagem original do Vale que por sua presença em meio à cidade busca reidentificar e requalificar a vida urbana.

Sobre esta valorização da "estética da Natureza" verificada a partir da segunda metade do século XX, Serrão ${ }^{28}$ faz a seguinte consideração:

"O aparecimento recente de um amplo conjunto de orientações subsumíveis (sic) numa "estética da natureza" não se limita, porém, a retomar um realismo e um naturalismo de origem e contornos antigos. Vem sobretudo enfrentar todo um conjunto de problemas novos.

A reabilitação geral do belo inscreve-se no desejo de reencontrar, finda a era das descontruções, um novo princípio de ordem, presente no gosto pelas pequenas coisas, no elogio do simples, na valorização do essencial. Como ingrediente de uma recuperação de uma

28 - SERRÃO,_Adriana Veríssimo. Filosofia e Paisagem: Aproximações a uma Categoria Estética. Lisboa, 2004 
vida boa e correlato de uma existência de prazer equilibrado, a fruição pacificadora da beleza adequar-se-ia mais do que o gigantismo do sublime à necessidade de reorientação de indivíduos perdidos em sociedades massificadas. Mas para a reabilitação do belo "da natureza" contribui decisivamente o elemento inteiramente específico que o nosso tempo vive com dramatismo: a forte consciência da natureza como uma realidade que se encontra em perigo. "

É neste sentido que notamos como para EG a Natureza assume uma existência autônoma em meio ao Vale, autolegitimando-se e assumindo uma consistência ontológica. À natureza é reclamado não só como um valor estético, mas também ético dentro da paisagem, uma maneira de reassumir o pacto entre o Homem, o indivíduo, e o Mundo.

Ao considerarmos o papel de restituidor de uma "ordem harmoniosa com o cosmos" e a experiência de EG em São Paulo, antes como um estudante, depois como um profissional e por fim como um viajante, não podemos deixar de lembrar os comentários de Serrão acerca dos pensamentos do filósofo Joachim Ritter:

"Ritter articula, de um ponto de vista histórico-social, o contraste marcante nas sociedades modernas entre a contemplação estética e a natureza objetivada, primeiro pela ciência, depois pelo trabalho. A formação da sensibilidade estética permitiu compensar a dimensão vital e significante da natureza que a razão da ciência desistiu de compreender e da qual estará, para sempre, afastada. O contemplador, o caminhante, e agora o turista, são os modernos sujeitos da paisagem, e a fruição que experimentam no plano do sentimento [é] a resposta à necessidade de recuperarem o que a sociedade, no processo de reificação do mundo, teve necessariamente de colocar fora dela: os condicionalismos naturais foram substituídos por restrições sociais; aos ritmos das estaçõese das colheitas sucederam-se os do labor, da profissão e do negócio. (...)

A estética da paisagem representa a possibilidade de restaurar interiormente uma unidade perdida, que foi outrora sentida como presença real, exterior e abrangente"29

Passando para a questão do uso da tecnologia, notamos que esta dava-se, conforme as palavras de Gomes, como um elemento capaz de tornar a proposta "voltada e

29 - SERRÃO,_Adriana Veríssimo. Filosofia e Paisagem: Aproximações a uma Categoria Estética. Lisboa, 2004, p. 93 
aberta para o futuro porvir" ${ }^{\prime 30}$. Neste sentido é possível estabelecermos um paralelo entre estas ideias e as defendidas pelo urbanista francês Eugene Henárd (1849-1923) que serviram de inspiração para Prestes Maia formular em 1930 seu Plano de Avenidas. Para Henárd ${ }^{31}$, autor do meta-projeto La ville de l'avennir (A cidade do porvir, do futuro - tradução livre do autor) era papel do urbanista "investigar a influência que o progresso da ciência moderna e da indústria pode exercer sobre o planejamento e, particularmente, sobre o aspecto, das Cidades do Futuro".

Assumindo esta postura EG propõe aa reformulação do então Terminal Bandeira em um terminal intermodal, onde seriam implantadas vagas de estacionamento, paradas para ônibus municipais e plataformas de embarque e desembarque de veículos expressos para os terminais aéreos de São Paulo, na época Congonhas, Viracopos e o então em obras Cumbica. Além desta possibilidade de embarcar e desembarcar de qualquer lugar do mundo em meio ao centro de São Paulo, EG sugeria que fossem criadas plataformas elevadas nos "topos dos prédios vizinhos ou em torre própria a ser construída" a fim de realizar a aterrissagem e decolagem de helicópteros e "outras tecnologias que estão por serem criadas."32

Não obstante estas abordagens que traziam para o espaço do Vale a conexão com todo o globo terrestre, Gomes sugere também a utilização da tecnologia para a realização de pequenos deslocamentos, inclusive aqueles internos ao próprio Vale. Para tanto o autor propõe a criação de um circuito de "monorail" ou, à semelhança do projeto da "Galeria de Pedestres" de Benno Peremutter de 1974³, de circuitos de esteiras rolantes que conectariam os diferentes pontos do Vale e do centro de São Paulo conforme sua importância e pertinência urbana, facilitando assim as trocas e as relações sociais. Para Gomes a requalificação do Vale do Anhangabaú parece surgir, portanto, como uma oportunidade de reconexão para São Paulo, seja ela com a ordem cósmica, com a Natureza, com o Mundo ou com seus próprios habitantes.

\footnotetext{
30 - Elgson Gomes in A construção São Paulo n.1755

31 - HENÁRD, E. (1910). The cities of the future. Transactions (p. 5). Londres: RIBA.

32 - Elgson Ribeiro Gomes in A Cosntrução São Paulo, n. 1745

33 - No início de 1974 Benno Peremutter apresentaria à Coordenadoria Geral de Planejamento (COGEP) o projeto da Galeria de Pedestres. Por esta galeria que se pelo arco sul do Perímetro de Irradiação seria possível conectar a Praça da República à Praça da Sé. Esta proposta seria incorporada por Artigas em seu plano para o Anhangabaú.
} 
Partindo para análise dos trabalhos de $\mathrm{BB}$ e ADK, ambos pertencentes ao grupo Terraço-Vala e liderados por arquitetos graduados no ultimo quartil de 1960, com exceção de Julio Katinsky graduado em 1957, notaremos também algumas peculiaridades e rupturas em relação às demais propostas no que diz respeito aos usos do espaço público e usos do solo.

Analisando primeiramente os usos destinados ao espaço público notamos duas abordagens bastante distintas nestes dois autores, tanto do ponto de vista funcional quanto organizacional.

Iniciando pela análise da proposta de $\mathrm{BB}$, notaremos que estes autores sugerem para o espaço central do Vale a criação de um "passeio público"34, sendo que para tanto determinam cinco faixas paralelas, sendo as duas externas compartilhadas entre veículos públicos e pedestres, as duas intermediárias levemente rebaixadas e destinadas a vias expressas de uso exclusivo de veículos particulares, e a central destinada para o passeio de pedestres.

Acerca da terminologia "passeio público" empregada por Carlos Bratke para a descrição de seu projeto é importante fazermos algumas considerações.

Como sabemos, na história do Paisagismo e do Urbanismo brasileiro, a primeira vez que tal termo foi utilizado para denominar um espaço público foi em 1783 na cidade do Rio de Janeiro, quando o então Vice-Rei Don Luís de Vasconcelos sob a influência das ideias iluministas da época ordenou o aterramento da lagoa do boqueirão para a construção de um "jardim de prazer, um jardim público para servir à população da cidade" 35 .

Conforme observa Segawa ${ }^{36}$ a organização paisagística deste "jardim” estruturava-se a partir de um eixo central balizado em seus extremos pelos agrupamentos escultóricos do chafariz das Marrecas e da fonte dos Amores: "o passeante caminharia desde o chafariz das Marrecas por uma rua reta, uma rua arquitetonicamente composta com "simetria"; ultrapassaria o portão do Passeio e se veria cercado pela vegetação, o am-

34 - Termo utilizado por Carlos Bratke para descreve seu projeto durante concedida a esta pesquisa 35 - TERRA, Carlos. Os Jardins no Brasil no século XIX: Glaziou revisitado. RJ: EBA/UFRJ, 2000. p. 42.

36 - SEGAWA, Hugo. Ao Amor do Público: Jardins no Brasil. SP: Studio Nobel/Fapesp, 1996 
biente sombreado e fresco, visualmente contido pelas plantas e pelos muros opacos do recinto, apenas orientado pela trajetória perspectivada, que aponta como ponto de fuga a gruta artificial". Segundo Gallerani ${ }^{37}$ esta descrição revela "certa afinidade entre a organização da área e os três princípios básicos do urbanismo clássico, apontados por Pierre Lavedan: a linha reta, a perspectiva monumental e o programa".

A historiadora Anna Maria Monteiro de Carvalho, acerca do projeto paisagístico do Passei Público faz a seguinte consideração: "é um jardim cortesão, organizado segundo a estética do barroco ${ }^{38}$, esses jardins compunham-se de canteiros e aleias ordenados num traçado geométrico em que predominava a linha reta, e submetidos a um eixo central cujo foco era, evidentemente, o palácio, e o ponto de fuga, em geral, um esplêndido panorama que ampliava os horizontes da propriedade e o olhar do dono"

Feitas estas observações não podemos deixar de notar, portanto, haver evidentes correlações entre a proposta de BB e alguns princípios clássicos de composição e programação dos espaços públicos: assim como no Passeio carioca do século XVIII e em tantos outros projetos da mesma época, havia na proposta de BB a criação de um eixo de simetria arquitetonicamente construído, reforçado por maciços laterais muito bem definidos por vegetação e maciços de terra (perfil U); a disposição de elementos escultóricos em pontos de interesse tais como as pirâmides e pavilhões de cristal propostas para o cruzamento com Avenida São João e junto à Praça da Bandeira; e no ponto de fuga da perspectiva monumental, de um lado, o "palácio", que no caso do Anhangabaú seria incorporado pela Câmara Municipal, e do outro, o horizonte.

Mas se por um lado notamos correlações do trabalho de BB com aspectos o urbanismo barroco, sobretudo na construção de seu "passeio público", ao analisarmos as faixas laterais de seu projeto, desenhadas com geometria sinuosa, bem arborizadas e destinadas ao uso compartilhado entre pedestres e o tráfego lento de veículos públicos, podemos traçar correlações entre esta proposta e as estratégias bem mais recentes, tais como as Woonerf holandesas dos anos 60, uma vez que os arquitetos sugerem transformar o espaço das ruas Formosas e sua simétrica, por meio do dese-

37 - GALLERANI, Maria Aimée Chaguri. O Ideário lluminista no Passeio Público de Mestre Valentim in Paisagem Ambiente: ensaios - n.18 p. 121. São Paulo, 2004 38 - Fernando Chueca Goitia observa que, em se tratando de Urbanismo, a palavra "clássico", utilizada pelos franceses, equivale a barroco nos demais países europeus in GALLERANI, Maria Aimée Chaguri. O Ideário Iluminista no Passeio Público de Mestre Valentim in Paisagem Ambiente: ensaios - n.18 


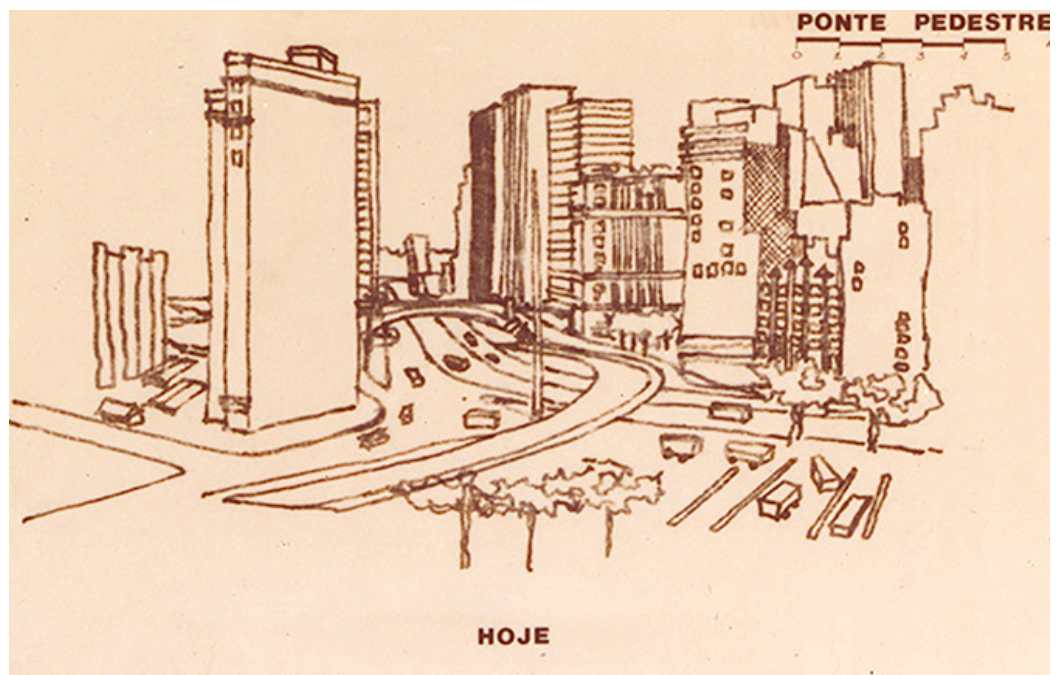

fig.112 Perspectiva comparativa antes-depois do Vale do Anhnagabaú, prancha entregue ao concurso - acervo Julio Gadelha Barreto
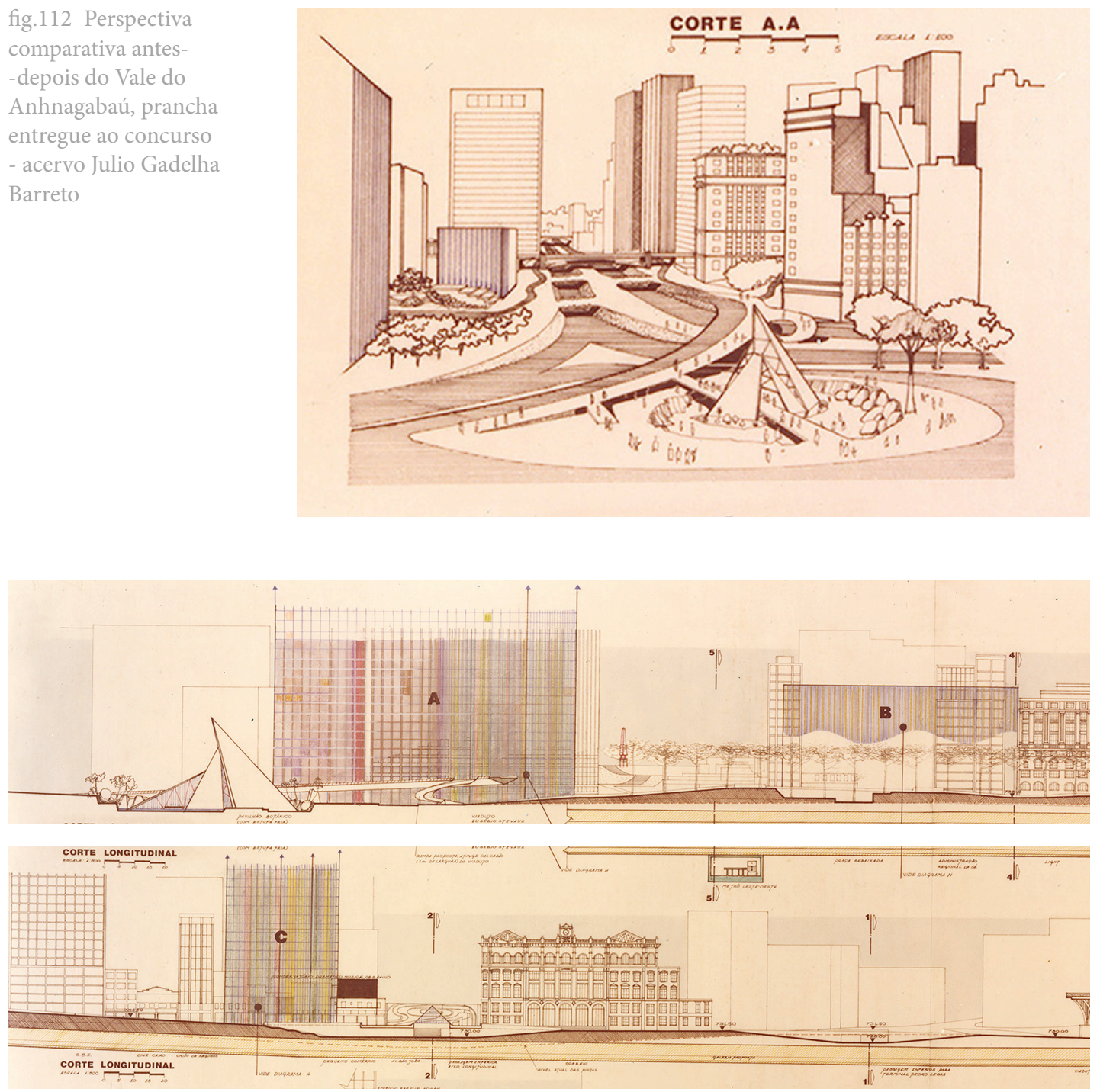

fig.113 Corte longitudinal do Vale do Anhnagabaú com destaque para os edifícios propostos, prancha entregue ao concurso - acervo Julio Gadelha Barreto 
nho de piso e ambientação, em um espaço social e de convivência, e não mais em um espaço destinado exclusivamente à eficiência da mobilidade veicular.

Neste ponto é importante lembrarmos que tanto Carlos Bratke quanto Joaquim Barreto eram arquitetos que durante os anos 1970 e 1980 buscaram expandir seus referenciais teóricos e projetuais, negando assim aos "dogmas e o modo de fazer" 39 preconizados pelo modernismo e, principalmente, pela Escola Paulista de Arquitetura. Deste período destacamos a exposição realizada na ocasião do $1^{\circ}$ Encontro Estadual de Arquitetos do IAB, sediado em Campinas em 1977, e a qual renderia a estes arquitetos o título de "não-alinhados" 40 . Antes do que adeptos à determinada escola ou movimento arquitetônico, estes arquitetos preservavam, portanto, uma postura crítica e aberta a experimentação.

Cabe destacarmos também a proposição que BB realizaram acerca da volumetria dos edifícios lindeiros ao Vale, expressivamente trabalhados nas pranchas de apresentação. A partir da identificação de alguns terrenos subutilizados os arquitetos propõem a criação de novas torres comerciais a semelhança daquelas que vinham sendo desenvolvidas por Bratke na virada dos anos 70 para 80 na região do Brooklin-Berrini. Com um princípio gerador comum à volumetria de todas elas, estas torres, mais do que reinserirem a região central na competição pela locação de áreas comerciais, buscavam garantir ao espaço do Vale uma legibilidade formal mais clara, conferindo ao espaço aéreo uma geometria precisa e reconhecível. Neste ponto, assim como Bouvard fizera setenta anos antes ao propor os “blocos gêmeos” dos Edifícios Prates, BB utilizam da construção dos edifícios lindeiros ao vale pra configurarem e orientarem sua paisagem.

Do ponto de vista figurativo, BB elegem alguns construções carregadas de simbologias para materializarem ao novo espírito que pretendem dar ao Vale. Ao Sul, junto à Praça da Bandeira, os arquitetos propõem a edificação de uma pequena estufa, um

39 - Carlos Bratke durante entrevista concedida à Julio Barretto in Joaquim Barreto - O exercício da Criação, FAUUSP, 2011

40 - O grupo dos "não-alinhados" foi um grupo que se formou espontaneamente, e era composto por Joaquim Barreto, Carlos Bratke, Tito Lívio, Vasco de Mello, Roberto Loeb, Pitanga do Amparo, Eduardo Longo e Artur Navarrete. Segundo Bratke este apelido apresentava um duplo sentido: por um lado expressava o sentido arquitetônico, ou seja, daqueles que não seguiam as mesmas literalmente as mesmas "linhas"; por outro expressava o sentido político, em referência aos países não-alinhados aos EUA durante a Guerra Fria. Entretanto, como o arquiteto revela, o surgimento deste grupo tem antes relações com a busca destes jovens arquitetos por seus "lugares ao sol" do que propriamente o desejo pelo embate com as gerações anteriores. 
"pavilhão botânico", no qual se realizaria o plantio e o estoque de sementes de espécie nativas do planalto paulista. A este pavilhão, além de um repositório de Natureza, estaria imbuída uma função educativa, uma vez que ele receberia visitações públicas individuais e coletivas.

Mas se ao "pavilhão botânico" recairia a função de origem da natureza, a função de origem urbana seria figurada pela Rosa dos Ventos instalada no cruzamento entre Avenida São João e Anhangabaú, numa clara alusão ao monumento do Marco Zero de São Paulo.
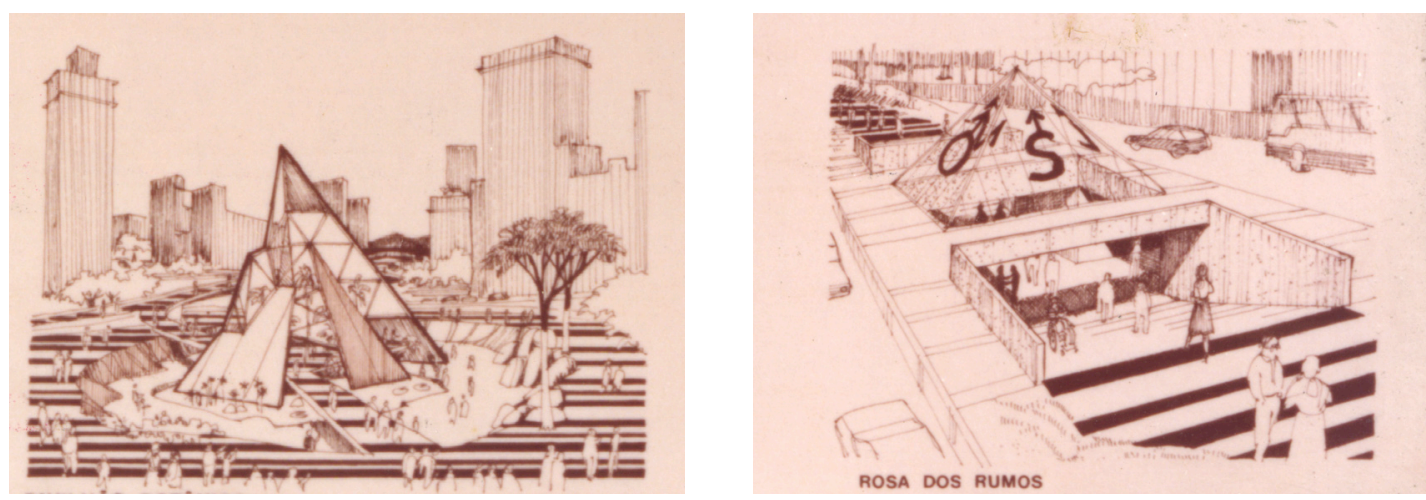

fig.114 Perspectiva

do Pavilhão botânico e da Rosa dos Ventos, prancha entregue ao concurso - acervo Julio Gadelha Barreto 
Mas se por um lado BB sugerem a criação de um "passeio público" no espaço central do Vale e organizam espacialmente sua proposta a partir de cinco faixas paralelas em planta, notaremos que ADK sugerem a criação de uma grande "esplanada, um vazio central"'l , possível graças à cuidadosa articulação, em corte, de três cotas de nível distintas. A primeira, subterrânea, constituiria uma grande "estação-central", zona compartilhada por veículos públicos e pedestres, mas sem o cruzamento direto de seus fluxos; a segunda, em posição intermediária, destinar-se-ia à esplanada principal, de uso exclusivo por pedestres; a terceira, mais superior, destinado à realização de vias expressas para o uso exclusivo de veículos particulares. Segundo os arquitetos o Vale do Anhangabaú passaria, assim, a "recuperar o cerne de sua área para o usufruto dos habitantes em suas manifestações cotidianas e especiais" e "a se constituir num elemento estrutural da rótula".

Ao tomarmos as definições e desejos apresentados por ADK, não podemos deixar de destacar como estas encontram paralelos nas propostas realizadas por Vilanova Artigas em 1974 para o Vale. Ao passo que Artigas apresentava como solução para o espaço do Vale a sua compreensão dentro de uma lógica sistêmica em função de todo o eixo viário Norte-Sul de São Paulo e, ainda, a construção de um vazio virtual capaz de articulá-lo e integrá-lo espacialmente, dar-lhe uma unidade, ADK repetem tal estratégia, porém desta vez radicalizando e aprofundando as intervenções. Ao invés dos terminais exclusivos de ônibus previstos em 1974, ADK sugerem a criação de uma estação intermodal, conectando assim o sistema férreo ao rodoviário e ainda concretizam o grande vazio, tornando-o não apenas um espaço virtual, intocável e compreendido à distância a partir dos terraços laterais, mas uma "esplanada" de fato, lugar a ser vivido, atravessado e ocupado.

Neste sentido é interessante notarmos como a ideia de "esplanada" de ADK se opõem e à noção de jardim apresentada por todas as demais equipes. Enquanto vimos em todos os demais trabalhos a utilização da natureza, domesticada com maior ou menor grau, como meio de mediação com o espaço construído, nesta proposta notamos a inexistência total de áreas vegetadas ou elementos naturais, tais como fontes, espelhos d’agua, etc. Ao invés disso, o que vemos é a conformação de uma praça totalmente

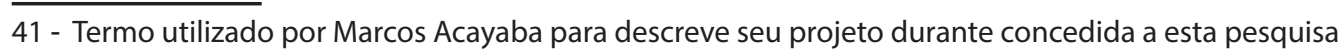


seca, ornamentada apenas por algumas esculturas abstratas e um intricado e abstrato desenho de piso, perceptível, sobretudo, dos topos dos edifícios vizinhos. A esplanada de ADK é um espaço utópico, racional, a ser conquistado, próprio para manifestações excepcionais e de grande porte. Se em todas as demais propostas a mensagem à população é o acolhimento e o convite às diferentes escalas comunitárias, aqui a mensagem é o encorajamento por uma ocupação verdadeiramente coletiva, um desafio à humanidade.
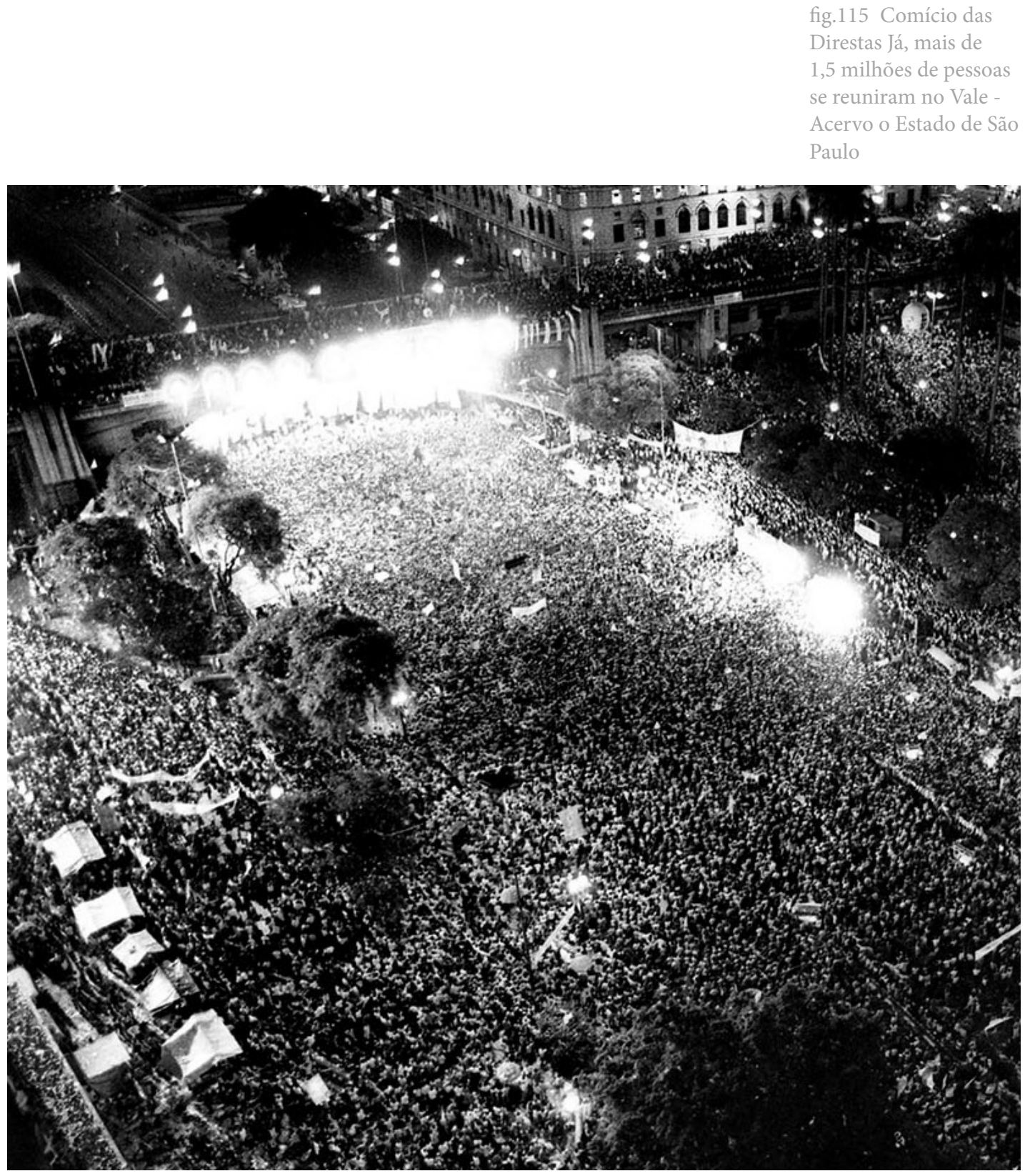
Outra característica notável da proposta de ADK que a distingue das demais é a afirmação do espaço do Vale como Centro Cívico e não Centro Comunitário, como abordado sobretudo em propostas como as de BZ e WKK. Neste sentido destacamos o tratamento dado por estes autores para a área da Praça da Bandeira, sugerindo a demolição do Viaduto Eusébio Stevaux e a realização de uma nova conexão viária, a qual permitiria um duplo exito: por um lado possibilitaria a realização do acesso dos motoristas ao espaço do Vale por meio de uma promenade architectural, um movimento ritualístico e preparatório para a revelação da magnutide própria daquele espaço; e por outro pemitiria a ligação direta entre o leito do Vale e o "anfiteatro natural” da Câmara de Vereadores., ampliando não só a área de "usufruto" da população como, também, encarnando a dimensão política à este espaço. Neste ponto cabe recordarmos as palavras de Giedon, Sert \& Leger, que em seu manifesto "Nove Pontos da Monumentalidade" de1943 dizem: "As pessoas querem que os edifícios que representam sua vida social e comunitária possam dar-lhes uma satisfação funcional maior. Querem satisfazer sua aspiração à monumentalidade, à alegria, ao orgulho e à comoção" 42 .

Vale lembrarmos que, como demonstra Gabriel ${ }^{43}$, durante os anos de 1950 e 1970 houve o "incremento significativo de projetos em vários programas, inclusive o de arquiteturas cívicas, (...) cujas propostas frequentemente se interessavam não apenas em atender os seus respectivos programas funcionais, mas igualmente, em ativar o potencial desses projetos como fator de renovação dos centros urbanos, onde o Centro Cívico teria também o papel de resgatar a centralidade e dar vida ao coração do conjunto urbano".

Mas se por um lado podemos estabelecer paralelos entre a proposta de ADK e algumas das obras realizadas no panorama arquitetônico brasileiro das décadas 1950 a 1970, não podemos deixar de notar também que esta equipe de arquitetos faz a sugestão de algumas práticas que fugiam a esta tradição. A mais notável delas seja talvez a inclusão e a utilização dos edifícios e lotes lindeiros ao Vale a fim de conferir e induzir ao seu espaço central algumas características, intenção que se revela com clareza se considerarmos o destaque dado à um novo edifício a ser implantado no 42 - SERT, Josep Lluis (1943) apud FRAMPTON, Kenneth. História Crítica da Arquitetura Moderna. São Paulo: Ed. Martins Fontes, 2003

43 - GABRIEL, Rachel Machado Marques. A Arquitetura Cívica Paulista - 1950-1970. X Seminário Docomomo, 2013 
corte transversal apresentado pelos arquitetos. A este esforço destacamos algumas ações de caráter programático e outras de caráter formal.

Do ponto de vista programático observamos duas propostas. A primeira concentrava-se na busca pelo aumento do potencial construtivo e o estabelecimento de cotas mínimas para a implantação de unidades habitacionais, sugerindo-se assim o incremento e variação da população residente na região. Neste ponto, entretanto, ao invés de sugerir a construção de novos conjuntos residenciais a semelhança daqueles recém-inaugurados na Região Metropolitana de São Paulo pela $\mathrm{COHAB}^{44}, \mathrm{ADK}$ sugerem a criação de empresas de capital misto para a construção de altíssimas torres que, dado seu caráter multifuncional, abrigariam espaços para comércio, serviços e unidades habitacionais de diferentes tamanhos e padrões. Assim como sugere Koolhas $^{45}$ dentro de sua Cultura de Congestão, notamos que estes três arquitetos paulistanos para além de conferirem à adição de pisos seu sentido econômico e quantitativo, buscam também a real multiplicação e condensação urbana.

Porém, se por um lado identificamos proximidades conceituais com algumas das teorias internacionais mais atuais da época (o conceito de Cultura da Congestão seria lançado nos Estados Unidos três anos antes), não podemos deixar de notar que do ponto de vista formal, pelo que podemos compreender a partir dos desenhos apresentados, as torres propostas aproximam-se muito mais das experiências Modernas dos anos 50 e 60 do que propriamente das tendências arquitetônicas posteriores. A divisão tripartite do edifício em embasamento, torre e ático; a orientação bilateral com empenas cegas nas faces menores; a fachada em pano de vidro sugerindo sua independência estrutural; o uso do ático como entablamento e a realização de faixas de transição ao longo do corpo do edifício ou então a torre cilíndrica com ático flutuante são, por exemplo, características verificadas também em edifícios sede da ONU, Copan e Athaydeville de Oscar Niemeyer.

44 - Sobre este processo Ana Cláudia Castilho Barone esclarece: “Em 1965, durante o regime militar, foram criados o Sistema de Financiamento da Habitação (SFH) e o Banco Nacional da Habitação (BNH). Desde então, a questão da habitacional urbana passou a ser financiada e gerida por um sistema de empréstimos do governo federal aos municípios. A partir dos anos 70, a centralização de recursos e decisões nas mãos do governo federal fez reduzir ao mínimo as realizações municipais independentes do BNH na área de habitação. No entanto o objetivo central perseguido pelo sistema não era a extinção do déficit de habitação no País, mas sim o desenvolvimento da economia por meio do estimulo à indústria de construção civil e da geração de empregos diretos e indiretos (Bolaffi: 1975)"

45 - KOOLHASS, Rem. Delirious New York, 1978 

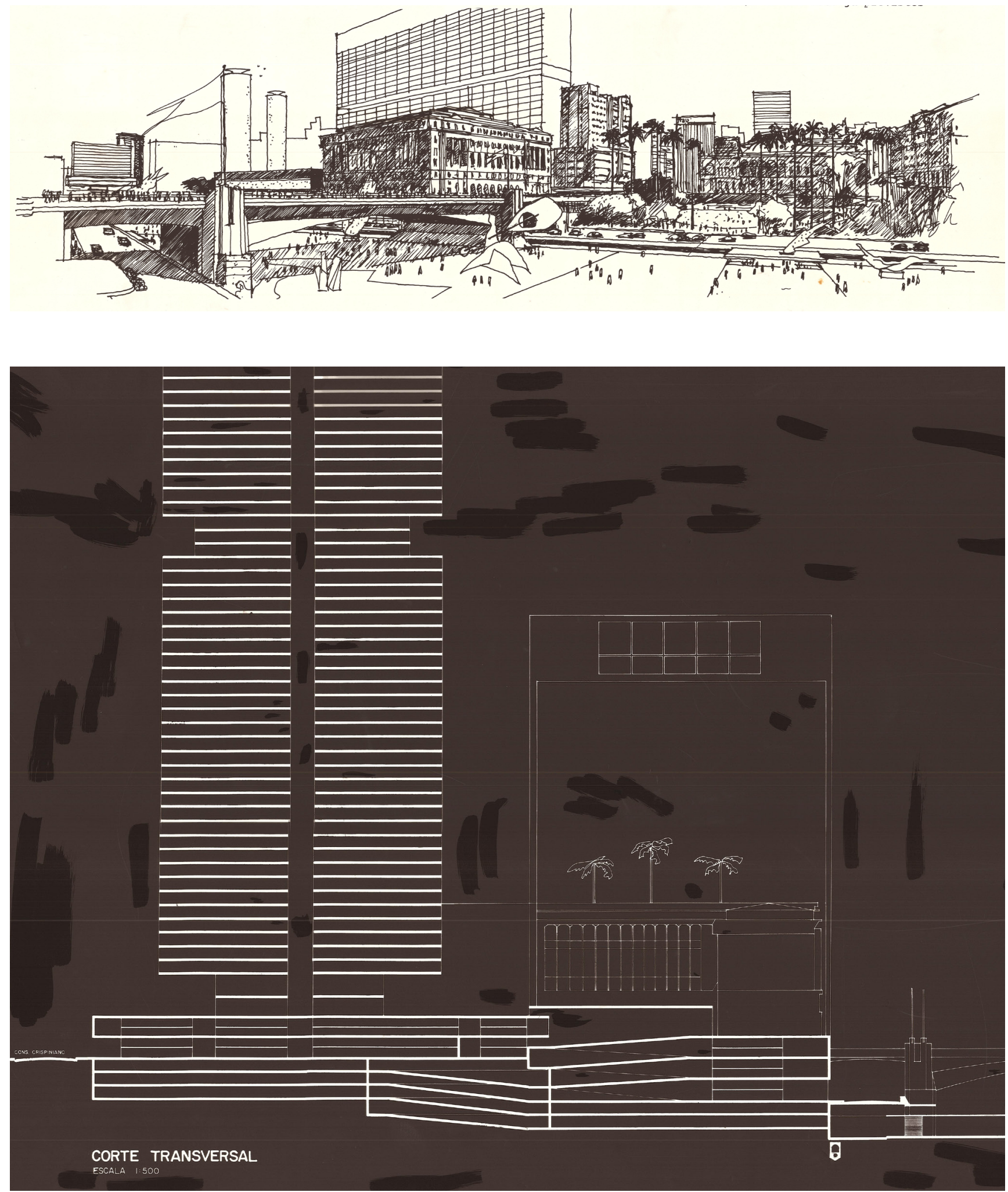

Reurbanização do Vale do Anhangabaú: propostas para recriação de uma paisagem 
A segunda proposta programática para o Vale apresentada por ADK consiste em promover em dois setores do seu entorno (Setor “C”) a nova Universidade Municipal de São Paulo e a recentralização dos Serviços Públicos Municipais, fato que permitiria por um lado a ativação da região econômica e culturalmente. Para tanto, os arquitetos sugerem a utilização da infraestrutura já instalada na região, tal como o Arquivo Histórico Municipal e Biblioteca Municipal Mário de Andrade.

Aqui é importante destacarmos como, assim como os demais programas, os arquitetos optam por distribuir tanto os novos edifícios educacionais quanto administrativos de forma perimetral à "esplanada”, conformando assim um anel programático que por oposição reforça o vazio central. Neste sentido salientamos como, do ponto de vista figurativo, são as próprias “manifestações” populares que são colocadas em destaque. O Monumento, torna-se assim, o próprio Povo.

\footnotetext{
fig.116 Página oposta, perspectiva apresentada ao concurso com destaque ao edifício proposto, acervo Marcos Acayaba 



\section{Considerações finais}

Ao analisarmos o Concurso do Anhangabaú à luz de suas contribuições históricas, sociais e culturais é possível fazermos algumas considerações acerca de sua validade, pertinência e falhas como processo de construção, debate e desenvolvimento do espaço público e da própria imagem da sociedade paulista.

A começar pelo processo em si do concurso, é de se destacar que este revelou-se uma forma legítima de produção e seleção para os projetos de um dos principais espaços públicos de São Paulo, permitindo uma competição aberta e igualitária mesmo que entre estruturas muito diferentes; entre as propostas premiadas encontraremos não somente figuras reconhecidas e os maiores escritórios de arquitetura da época, como também equipes formadas por estudantes, jovens arquitetos, escritórios pequenos, professores, etc.

Mas se por um lado o concurso permitiu esta abertura e intensa participação dentro do campo arquitetônico, não podemos dizer o mesmo no que se refere à participação popular e de extratos não técnicos da sociedade. Mesmo com todo o empenho e dedicação por parte do IAB na organização e realização dos debates abertos, fato é que não houve dentro do concurso espaço para aqueles que estavam para além dos domínios da Arquitetura participarem e contribuírem com a transformação e ressignificação do Vale.

Neste sentido é interessante notarmos como ao passo que o concurso tornasse um assunto próprio e auto referenciado da Arquitetura e afasta-se, portanto, de uma construção coletiva plena do espaço público, este revela-se, por conseguinte, um momento para a apresentação de possibilidades e alternativas, uma oferta de futuros possíveis, uma escolha entre opções. É neste interim que é lançado à classe dos arqui- 
tetos toda a responsabilidade pela a artialização in visu da paisagem, o papel de gênio inspirador das próximas gerações. Dado esse caráter singular dentro da produção cultural é preciso fazermos, portanto, o seguinte questionamento: seria a modalidade do concurso sempre a melhor opção para a produção do espaço público? Qual seria a consequência de uma civilização construída apenas a partir de concursos? E uma que nunca os tivesse?

Quanto às contribuições à cultura arquitetônica brasileira e paulista podemos fazer duas considerações. A primeira é que dado a heterogeneidade das propostas destacadas pela comissão julgadora, podemos dizer que o Concurso do Anhangabaú viria a contribuir com o processo de transição que se verificava desde meados dos anos de 1970 na arquitetura nacional, onde a arquitetura Moderna e Brutalista vinham perdendo força e grupos ditos "não-alinhados" conquistavam mais espaço. No caso específico do resultado do concurso destacamos os arquitetos Carlos Bratke, Joaquim Barreto e Marcos Acayaba como exemplos destes novos rumos que a arquitetura nacional começava a tomar.

Uma outra característica que podemos depreender da análise dos resultados do Concurso é a disposição por parte dos arquitetos formados pela FAU-USP em desenvolverem seus projetos manifestadamente de forma a possibilitar a ação política. Não por menos, o traço comum entre todos os ex-alunos desta instituição se revela na proposição de espaços centrais abertos e vazios, próprios para aglomerações e denominados como praças secas, tribunas ou esplanadas.

Mas se por um lado a partir destes resultados podemos afirmar que os arquitetos brasileiros da virada de 1980 apresentavam uma postura crítica e ao mesmo tempo comprometida, não podemos deixar de observar que a capacidade média destes autores de desenhar e dominar as escalas do espaço livre deixava a desejar. Fato é que mesmo estes sendo as melhores entre as noventa e três propostas entregues, ao nos aproximarmos de cada uma delas, redesenhá-las e medi-las, força e beleza das ideias à parte, não podemos deixar de notar que os aspectos dimensionais e qualitativos dos espaços propostos eram pouco trabalhados, aprofundados e desenvolvidos. Dentro desta linha poderíamos abrir certamente apenas três exceções: a proposta de WKK, a de $\mathrm{BZ}$ e a de $\mathrm{BB}$, autores que conquistaram por méritos próprios uma vasta experiência no campo do desenho da paisagem (caso de Rosa Kliass e Jamil Kfouri) ou no 
desenho e planejamento urbano (caso de Wilheim, Bastos e Bratke). Neste sentido faz-se necessário realizarmos aqui uma outra reflexão: dado a carência nacional por espaços livres públicos qualificados, como poderiam as instituições de ensino de Arquitetura e Urbanismo brasileiras desenvolverem em seus alunos as capacidades de desenhar e dominar as escalas do espaço livre independentemente das oportunidades que venham a surgir em suas carreiras? Seria necessário, dado a urgência por este domínio e a responsabilidade lançada à nós arquitetos em eventos como este do concurso, assim como sugere Kliass, criarmos faculdades específicas para este fim? Ou se não criarmos, quais seriam as alternativas para não só termos o domínio técnico do espaço, mas também a de significação e criação de paisagens?

Por fim, no que diz respeito ao legado cultural deixado por este concurso, apesar de sua maior contribuição fazer-se ainda hoje sensível em meio à cidade e ao cotidiano paulistano, é de se destacar como a falta de publicações, especializadas ou não, acerca deste processo parecem ter contribuído para o esquecimento paulatino de parte da população dos valores, conquistas e virtudes propostos à época do concurso. Coincidentemente ou não, o que vemos hoje é a sucessão de reformas e serviços de manutenção que, desreferenciadas, vão pouco a pouco transformando a atmosfera do Vale, tornando-o outro, metamorfoseando-o sem que percebamos. É neste "desaprender" que as relações com o espaço tornam-se menos profundas, sem raízes, e que vemos surgir de forma quase espontânea, como em um passe de mágica, soluções milagrosas, propostas salvadoras e novas verdades inquestionáveis. E neste sentido que o projeto dos espaços livres públicos devem ser, para além de belos, funcionais e bem construídos, acompanhados de um pacto social, uma ética própria à seu domínio, a qual deve ser renovada e reafirmada. 



\section{Referências}

\section{Livros}

AB'SABER, Aziz Nacib. Eckbo e o método de planejamento. São Paulo, 2006

ACAYABA, Marcos; KATINSKY, Julio Roberto. Marcos Acayaba. São Paulo: Cosac \& Naify, 2007.

ANDRADE, Mário de. Taxi e crônicas no diário nacional. São Paulo: Livraria Duas Cidades : Secretaria da Cultura, Ciência e Tecnologia, 1976.

ARAUJO, Demétrius Borges do S. G. de. Roberto Coelho Cardozo: Vida, Obra, Perpetuação e Resquícios de uma Produção Paisagística. Paisagem Ambiente: ensaios- 2006

ARTIGAS, J B V. Parque Anhangabahú. São Paulo: PMSP, 1974

ARTIGAS, J. B. Vilanova. Vilanova Artigas: arquitetos brasileiros. São Paulo, Instituto Lina Bo e P. M. Bardi, Fundação Vilanova Artigas, 1997

ATTOE, Wayne; LOGAN, D. American Urban Arquitecture. Catalysts in The Design of Cities, Berkeley: UCLA, 1992.

BARNETT, Jonathan. An introduction to urban design. New York Harper \& Row, 1982

BARRETO, Julio G. Joaquim Barreto: o exercício da criação. São Paulo: FAUUSP, 2011.

BESSE, Jean-Marie. Ver a Terra: seis ensaios sobre a paisagem e a geografia. (V. BARTALINI, Trad.) São Paulo: Perspectiva, 2014

BOLAFFI, Gabriel. Habitação e Urbanismo: o Problema e o Falso Problema. São Paulo: USP.

BORBA, Guilherme Galuppo. A paisagem dos lugares. Teoria e práticas na periferia da metrópole paulistana: o caso do Jardim Celeste e entoytrno. São Paulo: FAUUSP, 2014.

BUCCI, Ângelo. Anhangabaú, o Chá e a Metrópole. São Paulo: FAUUSP (Dissertação de Mestrado), 1998

CAMARGO, Odécio Bueno de. Jules Martin: artista, patriota, empreendedor. São Paulo: Edicon, 1996. 
CAMPOS NETO, C. M. Os rumos da cidade: urbanismo e modernização em São Paulo. São Paulo: Faculdade de Arquitetura e Urbanismo da Universidade de São Paulo, 1999

CAMPOS, E. Arquitetura paulista sob o Império. São Paulo: Faculdade deArquitetura e Urbanismos da Universidade de São Paulo, 1997

CASTRO, Luiz Guilherme Rivera de. São Paulo e sua área central: planos, políticas e programas recentes. in Revista Pós. São Paulo: AUUSP

CORAJOUD, Michel. A paisagem é o lugar onde o céu e a terra se tocam. Em SERRÃO, Adriana. Filosofia da Paisagem: uma antologia. Lisboa: Centro de filosofia da Universidade de Lisboa, 2011

ECKBO, Garret. People in a landscape. New Jersey Prentice Hall, 1998

ECKBO, Garrett. Urban landscape design. New York McGraw-Hill Book Co, 1964

FLORENCE, Luiz Ricardo Araújo. Planos para área Central : Análise crítica dos Planos de Intervenção e Operações Urbanas direcionados à área central da cidade de São Paulo. FAUUSP, 2001

FRAMPTON, Kenneth. História crítica da arquitetura moderna. São Paulo: Martins Fontes, 2003.

FRAMPTON, Kenneth. Megaform as Urban Landscape, 1999

FURTADO, Celso. Análise do "Modelo" Brasileiro, 1982, 7ª edição, Editora Civilização Brasileira, Rio de Janeiro,

GABRIEL, Raquel Machado Marques. Três Poderes: A Arquitetura Cívica Paulista, 1950-1970 . X Seminário Docomomo Brasil 2013

GALlERANI, Maria Aimée Chaguri. O Ideário Iluminista no Passeio Público de Mestre Valentim in Paisagem Ambiente: ensaios - n.18 p. 121. São Paulo, 2004

GOSLING, David. Concepts of urban design. London Academy Eds. New York St. Martin's Press 1984

Hall, P. (1996). Cities of tomorrow: An intellectual history of urban planning and design in the twentieth century. Oxford, UK: Blackwell Publishers.

HALPRIN, Lawrence. Freeways. New York : Reinhold Pub. Corp, [1966].

Halprin, Lawrence. The RSVP cycles: Creative processes in the human environment. New York: G. Braziller.

HENÁRD, Eugene. The cities of the future. Transactions (p. 5). Londres: RIBA, 1910

HEPNER, Alexandre. Desenho urbano, capital e ideologia em São Paulo: Centralidade e forma urbana na Marginal do Rio Pinheiros. 2010. Dissertação (Mestrado em Paisagem e Ambiente)

- Faculdade de Arquitetura e Urbanismo, Universidade de São Paulo, São Paulo, 2010.

HEREÑU, Pablo. Sentidos do Anhangabaú. São Paulo: Faculdade de Arquitetura e Urbanismo da Universidade de São Paulo, 2007

HOUGHTON-EVANS, William. Architecture and urban design. Lancaster New York [etc.] 
Construction Press, 1978

KLIASS, Rosa Grena. Evolução dos parques urbanos na cidade de São Paulo. São Paulo: FAUUSP, 1989

KLIASS, Rosa Grena. Planejamento dos espaços públicos. São Paulo: ABAP, 1983

KLIASS, Rosa Grena. Parques urbanos de São Paulo. São Paulo: Pini, 1993

KOOLHAAS, Rem. Delirious new york: a retroactive manifesto for manhattan. New York: Monacelli Press, 1994.

KRIEGER, Alex; SAUNDERS, William. Urban Design ,2009

LAMAS, José M. Rossano Garcia. Morfologia Urbana e Desenho da Cidade. Lisboa: Fundação Calouste Gumbelkian, 1993

LANG, Jon T. Urban design. A typology of procedures and products : illustrated with over 50 case studies. Oxford Architectural Press, 2005

LE GRAZIE, Vera Lucia. Renovação urbana São Paulo: Vale do Anhangabaú. São Paulo: FAUUSP, 1981

LEME, Iracy Squillaro Abranches.Os espaços livres de uso público no centro da cidade de São Paulo. São Carlos: EESC-USP, 2001

LIMA, Catharina P. C. dos Santos. Natureza e cultura: o conflito de Gilgamesh . Paisagem e Ambiente, São Paulo, n. 18, p. 7-57, 2004.

MACEDO, Silvio Soares. Paisagismo Brasileiro na virada do Século: 1990-2010. São Paulo: FAUUSP; Unicamp, 2012

MACEDO, Silvio Soares. Quadro do paisagismo no Brasil. São Paulo, Fauusp; Banco Itau, 1999

MAGNOLI, M. M. E. M. Paisagismo Não é Jardinagem (?)

MCHARG, Ian L. Design with nature. Garden City, N.Y. : Natural History Press, 1969.

MARTINS, Talita Rocha. Lawrence Halprin. Contribuições para uma prática compreensiva na arquitetura da paisagem. 2014. Dissertação (Mestrado em Paisagem e Ambiente) - Faculdade de Arquitetura e Urbanismo, Universidade de São Paulo, São Paulo, 2014.

MAYUMI, L. A Cidade Antiga nos CIAM, 1950-59. São Paulo: FAUUSP.

NOBRE, Eduardo Alberto Cusce. Políticas urbanas para o centro de São Paulo: renovação ou reabilitação? Avaliação das propostas da prefeitura do município de São Paulo de 1970 a 2004. in Revista Pós, número 25. Pag. 214-231. São Paulo: FAUUSP

OLIVEIRA, Fabiano Lemes de. Modelos Urbanísticos Modernos e Parques Urbanos: As Relações entre Urbanismo e Paisagismo em São Paulo na Primiera Metade do Século XX, 2008

OTAGA, Paulo Tomio. Vale do Anhangabaú. São Paulo: FAUUSP, 1981

PACHECO, Paulo Cesar Braga. O risco do Paraná e os concursos nacionais de Arquitetura entre 1962-1981. 2004. Dissertação de Mestrado - Pontifícia Universidade Católica do Paraná e 
Universidade Federal do Rio Grande do Sul

QUEIROGA, Eugenio Fernandes. A megalópole e a praça: o espaço entre a razão de dominação e a razão comunicativa. 2001. 351 p. Tese (Doutorado em Arquitetura e Urbanismo) Faculdade de Arquitetura e Urbanismo, Universidade de São Paulo, São Paulo, 2002.

QUEIROGA, Eugenio Fernandes. Dimensões públicas do espaço contemporâneo: resistências e transformações de territórios, paisagens e lugares urbanos brasileiros. São Paulo: FAUUSP, 2012

REIS FILHO, Nestor Goulart. Megaestrutura: solução para o Anhangabaú. São Paulo: Pini, 1972

RETTO, Adalberto. Modelos e Referências urbanísticas. A Cidade Vista pelo Vale. Uma Discussão do Espaço Público em São Paulo no Século XX, 1996

RICCA JUNIOR, Jorge. Anhangabaú: construção e memória. São Paulo: FAUUSP, 2004

RIO, Vicente del (org). Siembieda, William. Alcantara, Denise (trad). Desenho urbano contemporâneo no Brasil. Rio de Janeiro : LTC, 2013.

Introdução ao desenho urbano no processo de planejamento. São Paulo: Pini,

1990.

RITTER, Joachim. Paisagem: sobre a função do estético na sociedade moderna. Em SERRÃO, Adriana, 2011.

ROGER, Alain. Natureza e Cultura: a dupla artilização. Em SERRÃO, Adriana, Filosofia da Paisagem: uma antologia. Lisboa: Centro de Filosofia da Universidade de Lisboa, 2011

SANTOS, Milton. A natureza do espaço: técnica e tempo, razão e emoção. São Paulo: Hucitec, 1996.

SANDEVILLE, Euler. Miranda Martinelli Magnoli: contribuição fundamental para uma teoria e ação do arquiteto na paisagem brasileira. uma aproximação de seus escritos. Paisagem Ambiente: ensaios - n. 21 - São Paulo - p. 81 - 100 - 2006

SANTOS, Michelle Schneider. A moderna Curitiba dos anos 1960: Jovens arquitetos, concurseiros, planejadores. VIII Seminário Docomomo Brasil

. Do traço ao concreto: Arquitetura brutalista no Paraná. Curitiba: X Seminário Docomomo Brasil, 2013

SANTOS. Milton. Espaço e método. São Paulo: Nobel, 1985

SEGAWA, Hugo. Ao Amor do Público: Jardins no Brasil. SP: Studio Nobel/Fapesp, 1996

SERRÃO, Adriana Filosofia da Paisagem: uma antologia. Lisboa, 2011

SIMMEL, George. Filosofia da Paisagem. Em SERRÃO, Adriana. Filosofia da Paisagem: uma antologia. Lisboa, 2011

SIMÕES JUNIOR, José Geraldo. Anhangabaú: história e urbanismo. São Paulo: FAUUSP, 1995

SIMONDS, John Ormsbee. Earthscape: a manual of environmental planning. New York Mc- 
Graw-Hill, 1978.

SOLÀ-MORALES, Manuel de. Manuel de Espaços públicos e espaços coletivos. Barcelona, A la Vanguardia, 1992

TERRA, Carlos. Os Jardins no Brasil no século XIX: Glaziou revisitado. RJ: EBA/UFRJ, 2000. p. 42.

TOLEDO, R. (s.d.). A cidade da Solidão. São Paulo: Objetiva.

TOLEDO, B L. Anhangabaú. São Paulo: FIESP ,1989

WALL, Ed. Salvaterra, Alexandre (trad). Desenho Urbano. Porto Alegre Bookman, 2012

WATERMAN, Tim. The Fundamentals of Landscape Arquitecture, 2009

WILHEIM, Jorge. A obra pública de Jorge Wilheim. São Paulo: DBA, 2003

WILHEIM, Jorge. Projeto São Paulo: propostas para a melhoria da vida urbana. Rio de Janeiro: Paz e Terra, 1982

WILHEIM, Jorge. São Paulo: uma interpretação. São Paulo: Senac, 2011

ZEIN, Ruth Verde. Rosa Kliass: desenhando paisagens, moldando uma profissão. São Paulo:

Senac, 2006

ZUMTHOR, Peter. Atmosféras. Gustavo Gili, 2003

\section{Arquivos da EMURB}

Caixas 1 a 7 com correspondências e ofícios da época do Concurso e de desenvolvimento do Projeto

Edital para Concurso Público para Reurbanização do Vale do Anhangabaú

Ata do Júri

\section{Catálogos e Periódicos}

Aqui, o futuro do Anhangabaú. Jornal da Tarde, p. 26, São Paulo, 9 jun. 1981.

Assembléia de CIAM 8 - Congresso Internacional de Arquitetura Moderna. Hoddesdon, 1951

Cadernos Brasileiros de Arquitetura, número 16, p. 119.

Carta de Atenas de novembro de 1933 - Assembléia do CIAM - Congresso Internacional de Arquitetura Moderna - 1933.

Catálogo da Exposição dos Projetos do Concurso do Vale do Anhangabaú. Masp. São Paulo, SP, 1981.

Entrevista com o Paisagísta Jamil Kfouri: http://jovempan.uol.com.br/noticias/conheca- 
-mais-sobre-a-vida-e-a-obra-do-urbanista-e-paisagista-jamil-jose-kfouri.html

Eis o futuro. Jornal da Tarde, p. 13, São Paulo, 10 jun. 1981.

Folha de SP - Julho de 1980 - "O Aguangabaú em Obras"

Folha de SP - Dezembro de 1980 até fevereiro de 1981 - Coluna editorial "O Vale em discussão"

O Estado de São Paulo - Concurso para o Aguangabaú. 21 nov. 1980

O Estado de São Paulo - Em um ano e meio o novo Anhangabaú. 10 jun. 1981.

Revista A construção São Paulo. números 1725, 1731, 1741, 1745, 1751, 1755: Pini, 1981

SOSA, M R ; SEGRE, R . Do Coração da cidade - a Otterlo (1951-59): discussões transgressoras de ruptura, a semente das novas direções pós-CIAM.

Suplemento Especial: Projeto. Arquitetura, planejamento, desenho industrial e construção. Jul. 1981 No31 .Aguangabaú: uma conquista dos arquitetos e da população".

VALE do Anhangabaú: os critérios do julgamento na ata. Jornal do IAB/SP, São Paulo, jun. 1981.

WILHEIM, Jorge. Vamos preservar o Vale do Anhangabaú. Minha Cidade, São Paulo, ano 05, n. 059.02, Vitruvius, jun. $2005<$ http://www.vitruvius.com.br/revistas/read/minhacidade/05.059/1974>.

WILHEIM, J. De espaço a lugar. Arquitetura e Urbanismo. n42. São Paulo, jun-jul 1992

ŽIŽEK, S. Ecologia sem Natureza. Revista Centro. < http://revistacentro.org/index.php/zizek/>. Acessado em 07/04/2016

\section{Entrevistas}

Paulo J. V. Bruna [diretor da EMURB]

Michel Gorski e Jamil Kfouri [primeiro colocado]

Péricles Varella Gomes [segundo colocado]

Sigbert Zanettini [terceiro colocado]

Carlos Bratke [menção honrosa]

Roberto Aflalo Junior[menção honrosa]

Joel Ramalho Junior [menção honrosa]

Marcos Acayabamenção honrosa]

Paulo Kawahara [menção honrosa]

José Vitor Soalheiro Couto e Roberto Ezell Mac Fadden [Presidente e Vice-presidente

EMURB 1989-1992] 



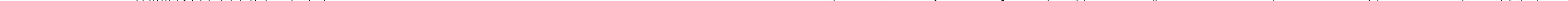




\section{Roberto Aflalo Filho}

(trecho da entrevista realizada em 23/05/2016)

Arquiteto Roberto, como você explicaria a proposta realizada pelo escritório Croce, Aflalo \& Gasperini em 1981?

Bom já faz muito tempo, eu não lembro de todos os detalhes, mas me lembro bem que nossa proposta buscava reaver ao máximo, naquele trecho central do Anhangabaú entre o Chá e Santa Efigênia, o espaço para os pedestres, aquele parque do começo do século XX.

Lembro que propusemos uma enorme "placa" com um rasgo no meio, lembrando a forma de um rio. Esta "placa" permitiria que o transito no sentido norte-sul fosse por baixo, desimpedido, e por cima teríamos um parque. A nossa ideia é que este espaço recriasse o antigo parque do Anhangabaú, com áreas ajardinadas, recantos para parada, para lazer e também conectasse as duas margens do Vale.

Por baixo a "placa" abrigaria ainda umas paradas de ônibus, que atenderiam as linhas de trólebus que a prefeitura tencionava implantar e as quais achávamos que deveriam circular por corredores exclusivos.

A ideia de criar aquele rasgo não sei ao certo de quem foi, acho que se deu naturalmente, uma vez que tínhamos de iluminar e ventilar os tuneis e paradas de ônibus e também queríamos criar uma imagem forte para o Vale, algo que marcasse bem a intervenção.

No entorno, em alguns terrenos que estavam vagos, propusemos criar algumas garagens verticais, integrada com o metrô. Na época o centro de São Paulo buscava se reerguer, tinham ocorrido uma série de intervenções, foram feitos calçadões, o próprio Concurso, enfim uma série de medidas que visavam resgatar e valorizar o centro, e achávamos que estas garagens seriam mais um atrativo além de irem de encontro com a ideia de pedestrianizar o maior número de ruas do centro. As pessoas chegariam pelo Anhangabaú, poderiam parar seus carros ali por perto, e então seguirem a pé pelos calçadões.

\section{Carlos Bratke}

(trecho da entrevista realizada em 01/11/2016)

Carlos Bratke, como se deu o desenvolvimento da proposta apresentadas por sua equipe no Concurso do Anhangabaú?

Inicialmente nossa proposta era muito diferente da que apresentamos no final o Concurso. O Joaquim Barreto e eu, logo que começamos a fazer o concurso, imaginámos que a melhor solução seria criar dois tuneis entre os viadutos do Chá e Santa Efigênia e assim liberar a superfície para criar um grande parque para a população no meio de São Paulo, muito parecido com o que a Rosa acabou fazendo. Chegamos inclusive a desenvolver um pouco esta ideia, alguns croquis e cortes, até o dia em que um colega calculista nosso, um italiano que tinha se mudado para São Paulo, veio nos visitar no escritório e vendo os desenhos sobre uma das mesas nos perguntou o que era aquilo.

Entusiasmados descrevemos nossa ideia, como o Vale daria espaço a um parque, ficaria livre dos carros, etc., porém ele não demonstrou muita animação. Pelo contrário disse que não gostava muito da ideia e que não via muito sentido em "esconder" os carros que por ali passavam. Para ele, lembro- me bem como ele dizia e gesticulava com as mãos, o Vale era exatamente aquela imagem vista dos viadutos onde os carros atravessando o centro formavam uma espécie de rio, aquela profundidade, aquele cruzamento...

Depois que ele foi embora conversei com o Joaquim, disse que achava que nosso amigo calculista tinha alguma razão, que talvez essa característica da travessia devesse de alguma forma tomar expressão, se revelar. Ele também concordou e então recomeçamos o trabalho. Talvez se tivéssemos seguido naquela ideia o resultado teria sido outro, quem sabe...

Quando recomeçamos assumimos como premissa a manutenção da calha viária e da profundidade original do Vale. Porém não queríamos perder totalmente aquele parque que tínhamos imaginado antes, nem a travessia facilitada para o pedestre, o que eram grandes ganhos da proposta anterior. Foi então que pensamos na solução de separar os transito de coletivos e automóveis privados, 
diminuir a área das faixas de rodagem no centro do vale e assim criar um novo canteiro central elevado capaz tanto de conectar as duas margens do Vale praticamente em nível quanto abrigar algumas áreas de encontro, contemplação, passeio e pequenos programas.

Esse canteiro central se estendia da Praça da Bandeira até depois do Viaduto Santa Efigênia, mas na prática esta ideia poderia se estender por todas as avenidas de São Paulo. Era uma ideia de caráter sistêmico que a partir da utilização de elementos pré-fabricados poderia ser realizada ao longo dos anos sem prejuízo. No extremo sul do Vale propusemos uma espécie de centro ecológico, uma estrutura para a educação ambiental da população no geral. No cruzamento da avenida São João também tinha alguns equipamentos de uso comunitário, mas estes de caráter mais cotidiano. Neste cruzamento, por ser para nós o ponto central do projeto, fizemos uma rosa dos ventos. No restante haviam alguns recantos protegidos por taludes, com bancos e área de estar.Os terminais de ônibus nós eliminamos a adotamos a circulação de linhas diametrais, conforme tinha sido anunciado no edital.

Do ponto de vista prático tínhamos bastante gente trabalhando no desenvolvimento do Concurso e por isso não tomou muito tempo para ser realizado. Lembro que neste processo a Lídia (Matiko) e o François (Guerin) foram imprescindiveis, realizando boa parte do trabalho de desenvolvimento e desenho. Eram uns desenhos bonitos, grandes, coloridos! Depois os originais foram pra exposição e nunca mais eu os vi.

\section{Marcos Acayaba}

(trecho da entrevista realizada em 05/07/2016)

Professor Acayaba, como foi que o senhor decidiu participar do Concurso para Reurbanização do Vale do Anhangabaú?

Bom, quando eu decidi que eu ia participar eu não tinha ainda nem a equipe formada, mas eu me interessei muito pelo tema do Concurso e resolvi me inscrever.

Sabe, quando eu era menino, como eu digo no meu livro, uma das coisas que eu mais gostava era quando saíamos de casa ali no Planalto Paulista, pertinho do Aeroporto, e íamos para o centro "dar uma volta na cidade". Chegávamos de carro pela Nove de Julho e então percorríamos o Vale do Anhangabaú, víamos os prédios, as palmeiras, o Teatro Municipal, o Viaduto do Chá e Santa Efigênia. Aquilo era maravilhoso, me dava uma sensação de cidadania tremenda! Ali era o centro da minha cidade, monumental...

Então foi por isso. Aí chamei dois amigos para fazerem comigo, o Katinsky e o Dente, professores da FAU também, e montamos a equipe. Tinha gente que achava que estávamos os três doidos, imagina...

E como se desenvolveu o trabalho da equipe?

Nós nos reuníamos à noite e passados uns dois meses, apesar de termos discutido muito as ideias, não havíamos produzido muitos desenhos. Tínhamos em mente recuperar o Vale como ele era nos anos 50, com as características daquela época. Achávamos que era importante manter a passagem de carros a céu aberto pelo Vale, para que todos pudessem participar daquela monumentalidade. Achávamos também que o problema não seria resolvido só dentro do Vale, mas que precisávamos olhar par o entorno, entender aquele espaço como parte de um sistema maior, por isso fizemos aquele diagrama com a rótula de irradiação. Mas apesar de tudo isso não produzíamos muitos desenhos finais, tínhamos uma porção de croquis, mas nenhum desenho final.

Aí, com o prazo quase acabando, o Katinskye o Dente estavam começando a pensar em desistir. Me lembro que era uma sexta-feira à noite, estávamos cansados, e eu falei para eles: "olha, eu vou embora e volto amanhã as 8 horas da manhã para desenhar este concurso até o fim. Se quiserem vir, venham". No dia seguinte estávamos os três lá e fizemos as três pranchas que apresentamos entre sábado de manhã e domingo à noite.

A verdade é que foi muito pouco tempo e por isso alguns desenhos estão tão pouco desenvolvidos enquanto outros estão muito desenvolvidos. Mas acho que conseguimos transmitir a ideia.

Falando especificamente da estratégia que vocês 
apresentaram de fazer uma grande estação de ônibus sob o Anhangabaú, da onde veio esta ideia.

Nós conhecíamos a proposta do Artigas, com os terminais e as passarelas, transformando aquilo tudo num único sistema. Sabíamos também que a prefeitura pretendia implantar um sistema de trólebus radial em São Paulo. Aí pensamos que a forma mais lógica seria então jogar o terminal para baixo e criar uma grande estação que se estendia da estação São Bento à estação Anhangabaú do metrô. Com isso a conexão entre os ônibus e entre os ônibus e o metrô se dariam mais facilmente, sempre cobertas. Sobre a estação criaríamos uma grande praça plana, dando uma unidade ao Vale. De cima desta praça seria uma espécie de tapeçaria para os prédios que estão no entorno.

Na entrada do Vale para quem vem pela Nove de Julho tem aquele viaduto que passa sobre a Vinte e três. Eu sempre achei que aquele viaduto fazia as pessoas entrarem de forma estranha no Vale, meio torto, meio de lado. Propusemos então que ele fosse demolido e que toda a geometria do encontro da Vinte e Três e da Nove de Julho fosse refeito. Com isso conseguimos chegar de fato o Anhangabaú até a Câmara, dando um sentido realmente cívico à praça. Para os motoristas também melhorava, porque a volta que eles teriam que fazer seria como uma preparação, uma anunciação, da entrada no Vale.

Depois o Maitrejean me disse que isso não pegou muito bem dentro do júri, que o acesso à Avenida Anhangabaú parecia muito indireto para alguns... enfim, nós achávamos que dessa forma era melhor

Na ponta norte previmos a criação de um túnel no encontro com a Avenida Senador Queiroz, o qual depois fariam. Como na época o fluxo da Avenida Anhangabaú cabia só de duas faixas para cada sentido, propusemos remanejar a circulação dos automóveis para as laterais, passando pelos vãos menores do Chá. Com isso estes veículos poderiam acessar diretamente os prédios do Vale.

Do ponto de vista do uso do solo a equipe de vocês também faz a proposições ousadas, como elas surgiram?

O Dente havia saído da Emurb fazia pouco tempo e ele conhecia bem a região do Vale e como o metrô poderia transformá-la. Além disso ele tinha participado dos projetos de reurbanização do Metrô para a linha Azul. Para ele era muito importante adensar as proximidades do metrô, então ele se colocou a pesquisar e a desenvolver os coeficientes ideais para a região do Anhangabaú. Se não me engano chegamos à conclusão que os terrenos deveriam ter coeficiente de 16. Por isso eram prédios altíssimos. Além disso deveriam ter uso misto, como comércio, serviço, habitação.

Além disso nós propusemos criar a Universidade Municipal, aproveitando-se da infraestrutura já instalada na região. Imaginávamos que os estudantes desta universidade circulariam pelo vale, utilizariam os bares, morariam na região, mais ou menos como era quando por exemplo a Politécnica era na avenida Tiradentes, a FAU em Higienópolis, etc. Nos parecia uma forma interessante de juntar educação e desenvolvimento urbano.

\section{Siegbert Zanettini}

(trecho da entrevista realizada em 03/02/2017)

Professor Zanettini, sobre a proposta apresentada pelo senhor e pelo professor Bastos, como esta se estruturava.

A partir dos anos 70, tanto eu quanto o Paulo, nós vínhamos buscando realizar uma arquitetura que fosse capaz de lidar com os problemas de uma forma integrada, abrangente, com uma visão holística. No caso específico deste projeto nós acreditávamos que a questão a ser resolvida era, portanto, a própria questão da cidade de São Paulo, que era, e ainda é uma cidade muito estranha. Eu costumo dizer que São Paulo não cresceu, mas inchou. É uma cidade onde as coisas não se deram de forma ordenada, onde o seu funcionamento, sua lógica, não se dá de maneira integrada. A proporção de espaços livres, o tamanho das ruas, a dimensão das coisas...tudo é pensado para uma razão que depois será ultrapassada em dez, quinze vezes. A avenida Anhangabaú, esta que propúnhamos cobrir e que o projeto vencedor cobria também, era um caso desses: havia muitos acidentes, vivia congestionada, não atendia à sua função.

Foi partindo desta lógica, desta vontade de resolver o projeto de uma maneira holística, que nos ocu- 
pamos do projeto. Buscamos compreender o Vale do Anhangabaú não só como uma passagem de veículos, uma artéria importante para o funcionamento da cidade, mas também como um lugar de São Paulo e uma oportunidade de restituir um pouco das áreas livres e do verde que fomos perdendo pouco a pouco.

Essa ideia de que o vale precisava voltar a ser um lugar propriamente dito era muito importante para nós. O centro de São Paulo sempre foi para nós o centro da vida, das atividades, da animação da cidade. Lembro-me de quando menino saíamos do Braz onde morava, pegavamos o bonde e íamos para a cidade. Lá passeávamos um pouco e, ali na São João, íamos ao cinema, tinha uma porção deles; íamos também à um restaurantezinho muito bom que tinha um sanduiche maravilhoso que comíamos no balcão. Era divertido, era bonito de ver. Era isso que queríamos resgatar, óbvio que um pouco diferente, sabiamos que nunca mais voltaríamos no tempo, mas esta animação, este fervilhar, era para nós essencial.

Foi por isso que o projeto de vocês aborda tanto a questão do desenho e da ocupação das ruas do entorno.

Sim, claro. Veja, para mim viver em comunidade em meio à rua é que era a coisa mais normal. Quando eu era criança e morava no Braz com minha família nós passávamos muito tempo na rua, nós e os vizinhos, pois as casas eram pequenas. De tempos em tempos, nas festas santas, cada família se organizava e cozinhava com a ajuda dos vizinhos a comida de sua região, cada uma de uma parte da Itália, para servir na festa, em meio à rua. Era uma maneira que tínhamos de conviver. Minha mãe, como éramos da região de Veneza, fazia um maravilhoso torteli.

Acho que talvez esta questão do uso das ruas venha daí, dessa minha memória, mas também desta vontade de pensar as coisas de forma integrada. A rua não poderia ser só um espaço funcional de passagem, mas precisava ser também lugar de encontro, de troca... acho que nesse ponto a nossa proposta se afastava um pouco da proposta do Jorge e da Rosa, pois nós saímos um pouco mais do Vale e nos aprofundávamos nas ruas do entorno.
Tocando neste assunto, realmente a propostas apresentadas por vocês eram muito semelhantes, apesar de terem desenhos diferentes tinham praticamente o mesmo programa. Houve em algum momento alguma troca de ideias, uma conversa entre vocês.

Não, nós não tivemos nenhum contato. Não saberia precisar porque existiam estas semelhanças mas confesso que até hoje não entendi como entre a proposta deles e a nossa, tão semelhantes entre si, foi classificado um outro projeto que, pelo que me lembre, não tinha nenhuma característica em comum com o que propusemos.

\section{Péricles Varela Gomes}

(entrevista realizada em 23/11/2016)

Professor Péricles, sobre a decisão de realizar o concurso e a montagem da equipe da onde surgiu a ideia? A participação entre todos os membros se deu de forma igual?

O papai (Elgson) e eu tínhamos um ótimo relacionamento. Estando no quarto ano, e com colegas interessantes, ele perguntou se eu gostaria de ajuda-lo neste concurso. (Apesar de um arquiteto consagrado, ele tinha esta frustração de não ganhar concursos, algo que o povo aqui de Curitiba era bom nesta época)

Assim sendo, eu convidei todos os componentes da equipe. Mesmo o Renato Brandao (formando em Engenharia Civil) era um grande amigo meu. Ele foi fundamental nas questões de engenharia de trafego e outros assuntos mais "engenheristicos" do projeto. E o Ricardo Zig, eu chamei quase no final para ajudar na produção fotográfica da maquete (mega-maquete, $1 \mathrm{~m}$ por $6 \mathrm{~m}$ creio era o tamanho dela)

Papai nem foi a Sao Paulo quando iniciamos os trabalhos, em marco nos viajamos de ônibus (cometa) e passados um fim de semana batendo perna e fotografando o Vale (chovia bastante nestes dias...)

Ah, fizemos uma visita ao escritório do Caminha e outros sócios do já falecido na época Roberto Zucollo (um grande amigo de Elgson) que nos deram 
uma feijoada no sábado e deram alguns palpites sobre a encrenca que era o Vale (em especial as estações de metrô, que eles conheciam bem)

Enfim, era uma equipe de alunos (de 21 a 24 anos) liderado por um Elgson Gomes bem veterano, 58 anos na época, as ideias centrais eram dele mesmo, mas ele sabia ouvir a rapaziada...

Nesta época, o escritório não tinha mais ninguém empregado (com exceção de minha irmã, recém-formada, Maria Luiza, que ajudou perifericamente, principalmente atendendo OUTRAS demandas do escritório nesta loucura que foi este concurso... alias a minha única participação em concursos de arquitetura e urbanismo)

Pude notar que a proposta de vocês trazia uma característica bem diferente das demais que era a de buscar repor ao centro de São Paulo e ao cotidiano da população a "participação do Verde" ao invés de simplesmente se preocupar com as questões de transporte por exemplo. Você poderia me dizer o porquê disso?

Esta era uma aspiração que o pai sempre teve na sua vida. Ele nascido em Florianópolis, mas que acabou se mudando para Curitiba aos 15 anos, sempre lamentou a perda do contato do a natureza. Mesmo o escritório dele aqui em Curitiba sempre foi em casas de bairros verdes.

Creio que também ele ficou bastante impressionado com os parques de Nova Iorque, Paris e Londres, cidades que ele gostava muito de visitar.

Outro ponto bem diferente que vocês apresentaram em relação aos demais concorrentes foi a previsão da conexão com os aeroportos e outros modais aéreos por meio de onibus expressos e plataformas de embarques em torres ou nos topos dos prédios da região. Você poderia comentar esta proposta?

Como mencionei, a partir de 1965 ele passa a viagem quase todo ano, participando dos congressos do iua (união internacional dos Arquitetos) e outros eventos. Em 1979, eu fui em viajem com ele a Madrid, e lembro ele me falando: veja aqui tem um ônibus do aeroporto para o Centro (porque São Paulo não ?)
Quanto a decisão de realizar a apresentação e o desenvolvimento da proposta por meio de maquetes da onde surgiu esta ideia? Havia algum motivo especial para isso?

Era uma marca registrada dele maquetes nos seus projetos, e nossa equipe de alunos era muito bom também em maquetes. Uma outra característica do Elgson era sempre projetar temas complexos em etapas... para demonstrar as etapas, maquetes são ótimas formas de comunicação.

\section{Jorge Wilheim}

(transcrição de trecho da entrevista contida em Jorge Wilheim: A obra pública de Jorge Wilheim)

Fale agora sobre o Concurso do Vale do Anhangabaú.

Em 1981, a prefeitura enfrentava o problema de alguns atropelamentos de jovens afoitos que atravessavam o Anhangabaú. Este havia se tornado um caudaloso rio de veículos, percorrendo o importante eixo norte-sul da cidade. O Viaduto do Chá canalizava um milhão de pedestres para a travessia do Vale, que permanecia sendo território do automóvel. A EMURB foi solicitada a resolver esse óbvio conflito entre pedestres e veículos, envolvendo multidões na área mais central de São Paulo. A primeira ideia foi aumentar o número de passagens para pedestres, e contrataram Vilanova Artigas para projetar passarelas suplementares que cruzassem o Vale, suscitando uma polêmica sobre a eficácia da medida.

Julio Moreno, então repórter do Jornal da Tarde, sugeriu ao prefeito Reynaldo de Barros que se fizesse um concurso para encontrar a melhor solução possivel, superando as polêmicas. Sob os auspícios do IAB, realizou-se o tal concurso, com 153 inscritos e 93 projetos entregues. Lá fui eu para mais uma participação...

Convidei a Rosa Kliass e depois o Jamil Kfouri para integrarem a equipe como paisagistas. Em meu escritório, trabalhavam naquele ano Jonas Birger e Michel Gorski. Embora o diagnóstico da situação não fosse difícil, a ficha demorou a cair, já que levamos um bom tempo para identificar a essência do problema: a reconquista para os pedestres de um vasto espaço central, totalmente 
ocupado pelo trânsito de veículos que nem sequer demandavam o centro, pois estavam de passagem. Eram 12.200 por hora. Em meu em tender, havia um enorme desperdício de espaço desfrutável! Criamos um parque de oito hectares para duas estações de metrô, a ser cruzado em todos os sentido, com liberdade, sendo capaz de receber atividades de todo tipo, espontâneas e organizadas. Numa extremidade, os ônibus previstos foram agrupados debaixo de uma laje que deveria servir de praça elevada no eixo do Vale, e a entrada neste, pela 23 de Maio e Nove de Julho, se fazia sob dois arcos que funcionavam como passarelas para alcançar a cobertura da estação de ônibus. Propusemos creches e sanitários ao lado das duas estações de metrô e um café ao lado do conjunto de repuxos, na então confluência da avenida São João, sítio da antiga praça do Correio.

Para criarmos esse espaço, recorremos ao afundamento do rio de trânsito, garantindo o fluxo indispensável da ligação norte-sul. Todos os problemas diagnosticados, mormente os de trânsito, foram resolvidos, resultando em pranchas de desenho bastante detalhadas. Foi a única vez em que, num concurso, terminamos a tarefa dois dias antes do encerramento do prazo! Depois de ter-me debruçado sobre as pranchas durante dias, escrevendo à mão as explicações do memorial descritivo, eu disse à equipe que me parecia havermos resolvido satisfatoriamente todos os problemas, mas que o resultado não era nada genial nem surpreendente - outros arquitetos certamente teriam chegado às mesmas conclusões, pois estas eram muito simples, muito óbvias...

Creio que a simplicidade foi o que nos garantiu a vitória, por que fomos os únicos a enxergar o óbvio...

\section{Michel Gorski}

(trecho da entrevista realizada em outubro de 2016)

Michel, você foi colaborador na proposta apresentada por Wilheim, Kliass e Kfouri, a qual podemos dizer é caracterizada pela criação de uma grande "tampa" sobre o Vale do Anhangabaú. Como você diria que esta ideia surgiu?
A ideia de "tampar" o Anhangabaú foi algo que foi se criando naturalmente, a partir de muitas e muitas conversas, muitos desenhos. Não foi algo que já imaginávamos à priori, mas uma ideia que foi se construindo aos poucos.

A partir de um consenso então...

Na verdade, não. A nossa equipe era bastante grande e ainda por cima composta por dois escritórios diferentes. De um lado tinha o escritório do Jorge, onde eu trabalhava, que tinha uma pegada mais "arquitetônica"; do outro o escritório da Rosa, que era especializado em paisagismo.

O processo de desenvolvimento se deu em paralelo, com as equipes trabalhando separadas e se reunindo para discutir. Discutíamos todos juntos, geralmente ao final do dia, quando depois do expediente todos podiam se reunir. Claro que o Jorge e a Rosa lideravam, mas no geral todos falavam alguma coisa, davam a sua contribuição. Por isso era um processo onde havia mais embate de ideias do que consensos absolutos.

E porque então tampar o vale?

Acho que todos nós concordávamos que era necessário resgatar o espaço do Vale para as pessoas, tornar a travessia delas mais segura e também garantir o fluxo ininterrupto de veículos. Além disso buscávamos um desenho forte, capaz de resgatar também o sentido de cartão postal que o Anhangabaú tinha. Lembro que a Carmem Lydia desenhou as perspectivas com muito esmero, cada folhinha das árvores, para ficar realmente bonito. Ela tinha um traço delicado...

Mas a questão viária foi muito importante também, sobretudo para nós da equipe do Jorge. Estudamos muito como as linhas de ônibus se organizavam, os pontos de engarrafamento, os retornos, fluxos, etc. É uma pena que o terminal da Bandeira não tenha sido realizado como tínhamos imaginado e no lugar dele tenham construído aquilo que construíram. 


\section{Jamil Kfouri}

(trecho da entrevista realizada em 01/11/2016)

Ao analisarmos e compararmos a proposta de 1981 com o projeto implantada dez anos depois notamos enormes diferenças em praticamente todos os pontos. Você poderia comentar isso?

Sim, exatamente, são dois projetos muito diferentes. Na verdade, são o mesmo projeto, mas em duas versões diferentes.

Quando nós estávamos realizando o concurso tínhamos pressa, as coisas tinham de se desenvolver rapidamente e por isso nos atemos sobretudo na estruturação dos espaços. Sabíamos que o mais importante era definirmos os espaços e os usos que queríamos que eles tivessem, mas o desenho este poderia mudar.

Em linhas gerais durante o desenvolvimento fomos totalmente fieis ao que havíamos proposto inicialmente: um terminal de ônibus em cada extremo do Vale, um ao sul e um ao norte, próximos ao metrô; uma praça de eventos, uma área de estar e uma área recreativa. Porém, do ponto de vista do desenho, isso mudou muito.

A começar pelo desenho da grande placa de quase 500 metros que ia do Chá à Santa Efigênia. O desenho daquele trecho não nos agradava nem um pouco então começamos a refazê-lo. Primeiro fomos traçando as linhas de força, os fluxos mais comuns, mais presentes, e disso surgiu a estrutura ondulada que ele possui hoje. Muita gente acha que esse gesto surgiu do movimento no sentido longitudinal do Vale, porém na verdade é o contrário: ele nasceu da somatória dos movimentos transversais, de travessia, do Vale.

Ai então, com esta ondulação definida fomos aos poucos ajustando os espaços menores. Primeiro acertamos a praça de eventos. Nós a invertemos, tornando o jardim do municipal o pano de fundo para sua tribuna. Se você pegar um compasso você notará que o centro desta curva cai exatamente na escultura do Ruy Barbosa que tem no jardim do Municipal. Partindo disso então criamos três gigantes, aquelas arquibancadas de granito, que serviriam com arquibancada aos espectadores.
Hoje vemos que há um certo descaso com estas estruturas que eram belíssimas. Se você reparar vai notar que o granito foi todo paginado em diferentes formatos...com o passar do tempo foram utilizando outros granitos para a manutenção, em formatos errados...isso quando houve manutenção.

Estes gigantes ainda conformavam pequenas áreas de eventos. Se você reparar no desenho de piso com a alteração do vermelho e do branco vai ver que isso fica muito claro. É uma pena, porém pouca gente sabe que esta praça de eventos foi desenhada para ser utilizada no sentido transversal do Vale, como se o Chá fosse uma tribuna e não um fundo de palco. Se ainda só as pessoas não soubessem disso tudo bem, mas a própria prefeitura não saber é que preocupa. Hoje a sombra do Chá é utilizada como fundo de palco, como coxia, e as pessoas que cruzam o Vale não vem o que acontece lá em baixo.

Um outro ponto que alteramos bastante foi a praça Pedro Lessa, mas esta não tanto por nosso desejo se não por necessidades mesmo. Nós queríamos aproveitar ao máximo as árvores que já existiam ali para criar um bosque e uma área de recreação. Entretanto o terminal que prevíamos para a Praça começou a crescer, tivemos de criar umas vias de acesso, alças de retorno, enfim um monte de coisa que acabou consumindo todo o espaço da praça.

Aliás esta questão das alças e vias de acesso é bem interessante. Quando começamos o projeto logo no início o CET não aceitou nossas alças de retorno e pediram alças muito maiores. O problema é que isto não cabia no projeto, extrapolavam em muito a área que havíamos previsto. Nós então nos debruçamos sobre este problema no escritório e o redesenhamos à exaustão. Não bastava simplesmente atender aos raios, tangentes e distâncias mínimas dos manuais. Nós queríamos desenhar estas vias como elementos da paisagem, coerentes com todo o espaço do Vale, do desenho do piso e mobiliário ao uso do espaço, e não só com suas próprias regras e lógicas. Foi assim que redesenhamos tudo, até mesmo as muretas de proteção.

Mas e no que diz respeito ao pontilhão curvo da São João? Como vocês conseguiram convencer o CET de não o executar? 
Na verdade, nós nunca tentamos removê-lo dali, apesar de nunca termos gostado dele. Nós sabíamos que ele não era bom, que atrapalhava a visual do eixo, que era uma obra meio estranha...porém sabíamos também que do ponto de vista dos fluxos e conexões era necessário. Isso que é o estranho de concurso: você sabe que aquela não é a melhor opção do ponto de vista do projeto, porém sabe também que tem algumas coisas que precisam ser feitas se você quer ganhar. Nesse caso, sabíamos que precisávamos manter a ligação com a São João se quiséssemos alguma colocação. A nossa equipe era comprometida, queríamos ganhar...

O projeto foi se desenvolvendo e o pontilhão manteve-se lá. Nós havíamos projetado e calculado toda a estrutura do pontilhão e as fundações e rampas de acesso já estavam executadas. Nós não gostávamos dele em absoluto, mas segundo nosso consultor de tráfego era uma necessidade do ponto de vista do fluxo esta ligação direta com a avenida São João, como poderíamos questionar?

Foi então quando um técnico da prefeitura depois de três anos de obra nos perguntou - "Vocês ainda querem fazer o pontilhão? A ligação com a Avenida São João já não existe há três anos e o trânsito do centro não parece ter demonstrado pioras, parece que se acomodou. ".

Era esse o motivo que precisávamos para removê-lo de lá. Retiramos o pontilhão, mas o buraco e toda a geometria para recebe-lo junto a avenida São João já estava feito...e o túnel já estava mais profundo do que precisava, não tinha mais volta. Então a Rosa e eu buscamos uma maneira de lidar com aquilo, foi aí que imaginamos aquela cascata e fonte que estão lá até hoje.

Foi assim então que surgiu aquele rebaixo no eixo da São João?

Sim. Quando nos vimos livres do pontilhão, mas já tínhamos o rebaixo do café definido nos preocupamos em como resolver aquele desnível. Levantamos duas possibilidades: a primeira, mais imediata, seria realizar uma passarela que atravessaria aquele vazio a semelhança de como o pontilhão o faria; e a segunda, a qual achamos mais interessante e acabamos escolhendo, a de criar um belvedere, um mirante, exatamente no eixo da São João, de onde as pessoas parassem no seu ponto mais baixo e avistassem, em primeiro plano uma bela cascata, $e$ ao fundo, em continuidade à ladeira oposta da São João, o prédio do Banespa e o Martinelli

A ideia, porém, de fazer o rebaixo naquele ponto sempre existiu. Na época achávamos importante criar um café naquele ponto, com sanitários e outros serviços também. Porém o café nunca veio, ficaram então só os sanitários e este tipo de programa sozinho acho que não tinha por onde se manter...então com o tempo, para evitar a manutenção, a prefeitura fechou os banheiros, o que piorou ainda mais a condição do rebaixo, tornando um espaço totalmente abandonado.

\section{José Victor Couto e Roberto Mac Fadden}

(presidente e vice-presidente da EMURB 89-92. Entrevista realizada em 18/01/2016)

Quando vocês chegaram a EMURB como estava a obra do Anhangabaú?

Couto - A EMURB encontrava-se praticamente desmontada. O Jânio Quadros, durante seu governo, a esvaziou. Só não a fechou, pois, para fechá-la, como ela foi instaurada por lei, por decreto não podia fechar. Tinha de ter uma outra leia que a fechasse. Ele até chegou a se mobilizar nesse sentido, porém não conseguiu...

Depois, ele descobriu que a EMURB podia captar empréstimo, e o seu interesse por ela voltou. Mas de qualquer forma a EMURB estava enfraquecida.

Mac Fadden - Mas, apesar deste sucateamento, a EMURB ainda era responsável por muitas obras. Pelo menos cinco grandes, a do Vale do Anhangabaú, a estrada do Jacu-Pêssego, o minianel viário, a Água Espraiada e o corredor Sudoeste-Centro, que era contituido pelos tuneis Pinheiros, Boulevard JK e tuneis Ibirapuera. Quando iniciamos nosso mandato, as construtoras envolvidas nestes projetos, reivindicaram uma dívida de 386 milhões de dólares. Nós contestamos, fizemos uma auditoria e chegamos a um valor de 172 milhões. Após isso ainda negociamos e chegamos num acordo de 103 milhões.

Do ponto de vista político nós tínhamos de decidir 
quais obras levaríamos a frente. Não casava com as ideias do partido, que pretendia atender sobretudo aos mais pobres, a periferia, gastar tanto dinheiro em obras que não privilegiariam a maioria. Esse era o caso do Boulevard JK, que nasceu dentro da Promon e só resolvia o problema deles. O Anhangabaú por outro lado, apesar de ser no centro de São Paulo, foi mantido como uma das prioridades, pois apesar de não estar na periferia, o centro é o lugar onde mais concentra todos os tipos de pessoas, ou melhor, quase todos, os mais ricos quase não circulam por lá.

Falando especificamente do Anhangabaú, quando recebemos a obra um dos tuneis já estava realizado, mas ainda faltavam o outro túnel e as obras de canalização do córrego. Digamos que a obra estava de 30 a 40\% realizada, mas já haviam gasto proporcionalmente muito mais. Nós então mudamos a forma de gerir aquela obra. O gerenciamento e fiscalização passou para as mãos da EMURB e com isso pudemos "segurar" as medições. Mudando isto pudemos, por exemplo, gastar 8 vezes menos no sistema de ventilação e 79 vezes menos no sistema de iluminação dos tuneis em comparação a gestão anterior. Outro exemplo foi na hora de comprar o granito para o calçamento do Vale: O primeiro orçamento que tínhamos, realizado por uma das gerenciadoras, era da ordem de 13 milhões de dólares. Quando nós os refizemos fomos para a casa dos 3,5 milhões.

É possível observar algumas diferenças entre o projeto original de 1981 e o projeto implantado em 1991. Como e porque, no período que estiveram à frente da EMURB, estas modificações se deram?

Couto - O projeto original previa um viaduto em alça que conectaria a avenida 23 de maio à avenida São João. Esta conexão havia sido prevista pelo Jorge em função das premissas que haviam sido passadas pelo concurso. Entretanto, os estudos mais recentes da época apontavam que esta conexão não mais se justificaria do ponto de vista do tráfego de veículos. Além disso, está conexão Sul-Oeste pelo Vale não fazia tanto sentido assim, sobretudo quando ela já se viabilizava de maneira muito confortável pela Praça Roosvelt e Minhocão.
Nós então conversamos com o Jorge, que achou a ideia muito boa e cortou do projeto dele aquele viaduto. Com isso foi possivel integrar a quadra do prédio do Correio e do conservatório ao desenho do Vale, o que depois chamaríamos de Boulevard da São João.

Nesse ponto é importante notar que graças a eliminação deste viaduto e a consequente diminuição no volume de tráfego naquele trecho da São João pudemos alargar as calçadas da avenida, entre a Conselheiro Crispiniano e a General Osório.

Quanto ao buraco que foi implantado pelo Jorge na posição do viaduto, ele sempre esteve lá. Desde o começo ele previa um café e um banheiro público naquela posição e preferiu mantê-los lá.

Outra modificação que ocorreu foi a supressão das paradas de ônibus nos tuneis. Nós até realizamos as bocas, mas eliminamos as paradas. O CET não concordava com aquilo e acabou barrando.

Talvez, uma terceira modificação que ocorreu nesta época foi a criação da Operação Urbana Anhangabaú. Quando nós assumimos a única operação urbana que estava em andamento era a Faria Lima, orquestrada pelo Júlio Neves e que, no nosso entendimento, atendia mais aos interesses do mercado do que população como um todo.

Por isso decidimos fazer as nossas, um pouco com o espírito de mostrar como deveria ser feito mesmo. Quem cuidou deste assunto foi o José Lefevre, fazendo um trabalho fantástico com todo um levantamento do patrimônio existente, estabelecendo os limites de crescimento e formas de ocupação possíveis. Mas infelizmente a operação não foi o sucesso que esperávamos. 


\section{Projeto 14 [menção honrosa]}

Autores:

Marcos Azevedo Acayaba - Arquiteto (São Paulo - SP)

Edgar Gonçalves Dente - Arquiteto (São Paulo - SP)

Julio Roberto Katinsky - Arquiteto (São Paulo - SP) 

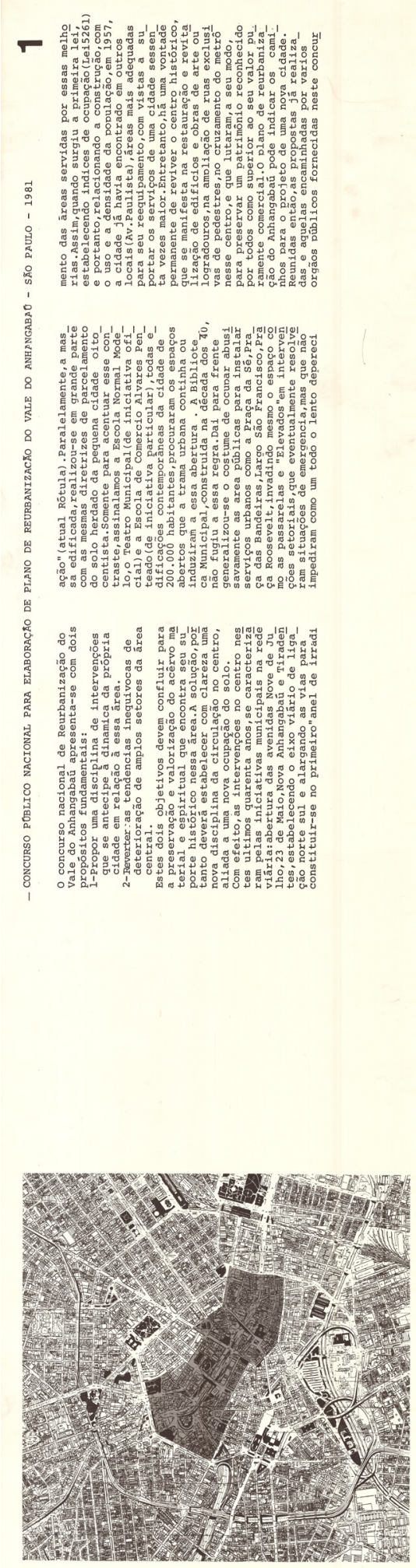
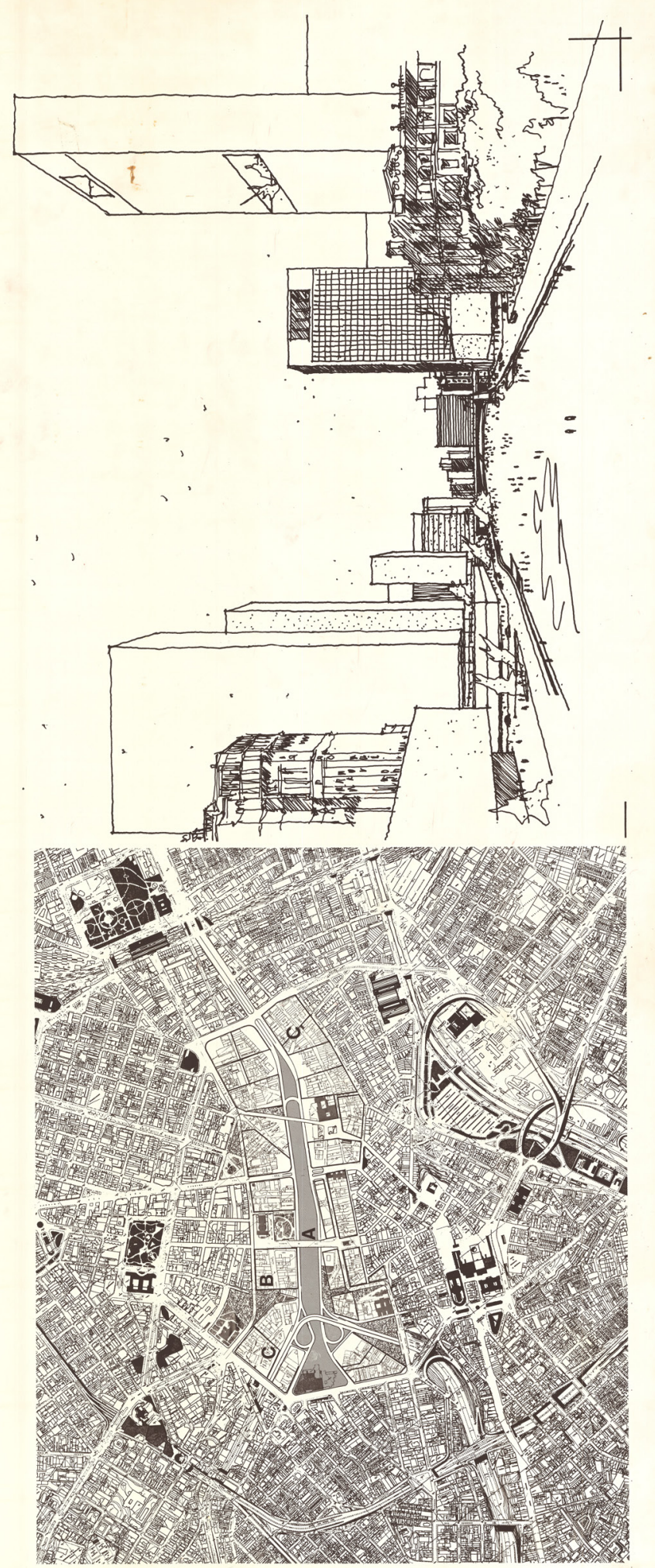


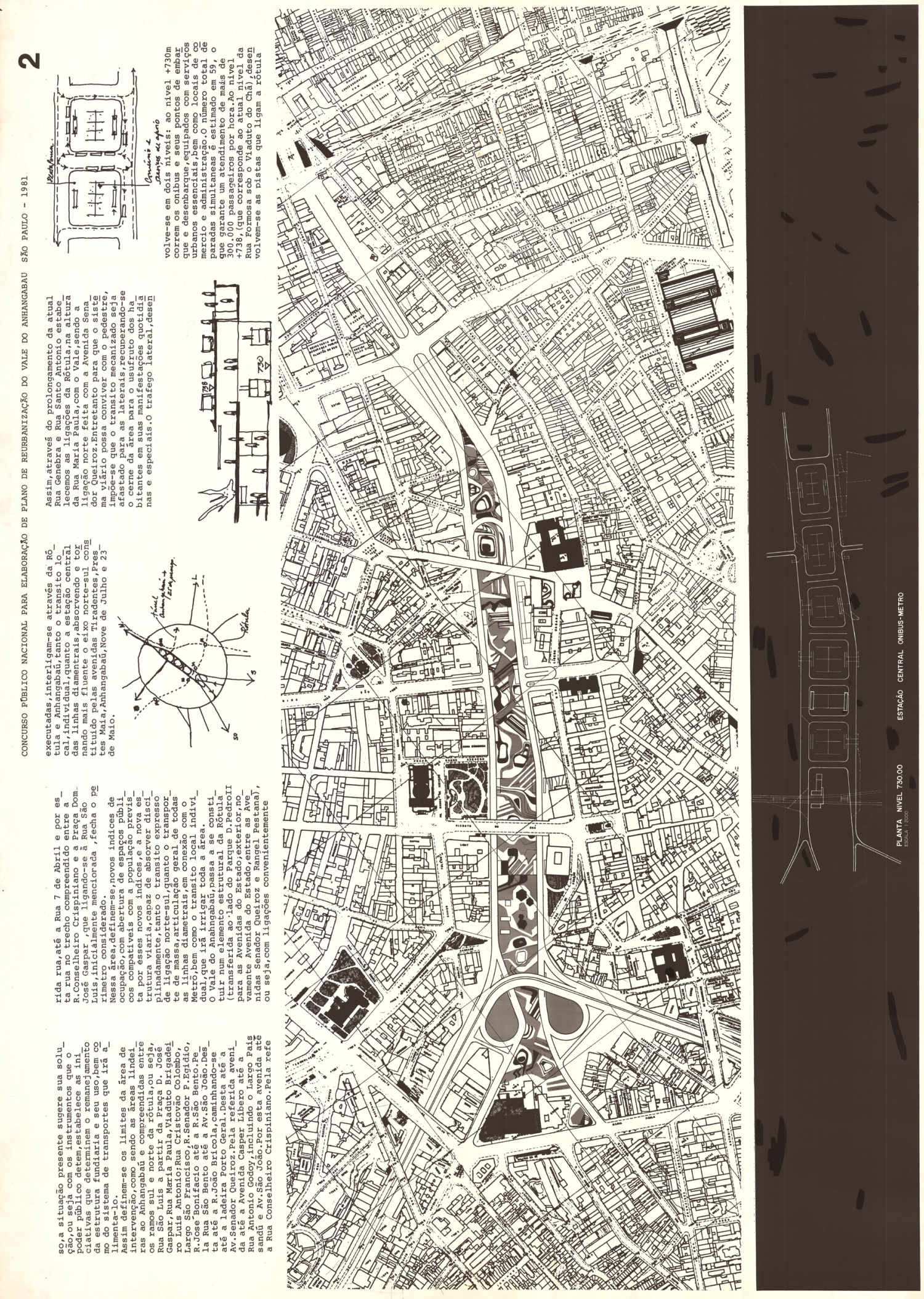

Reurbanização do Vale do Anhangabaú: propostas para recriação de uma paisagem 
(2)

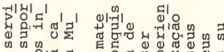

8.

等

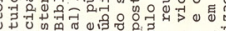

等

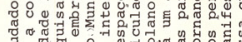

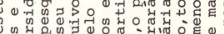

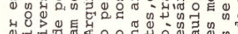

w

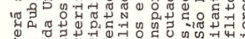

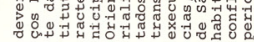

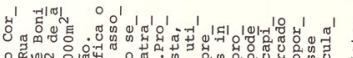

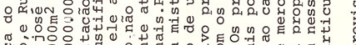

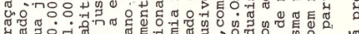
2.

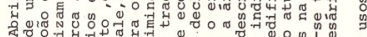
ข.

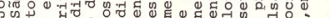

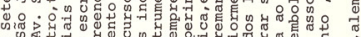

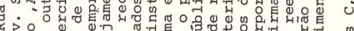

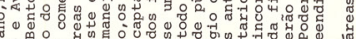

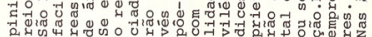

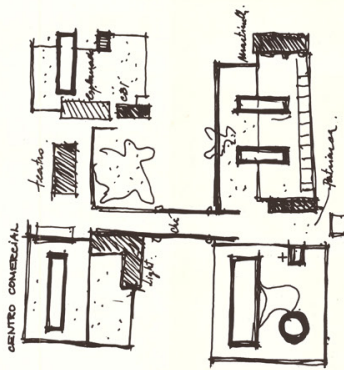

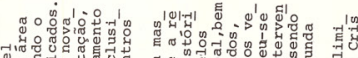

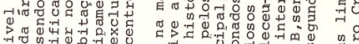

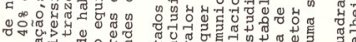

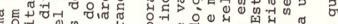

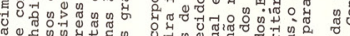

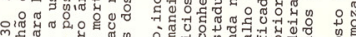
年

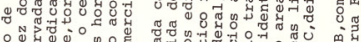

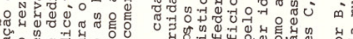

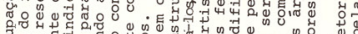

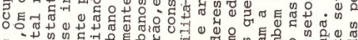

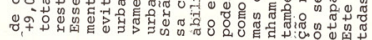

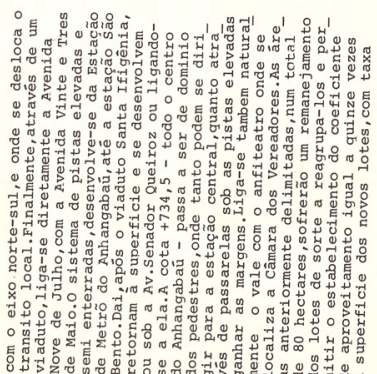

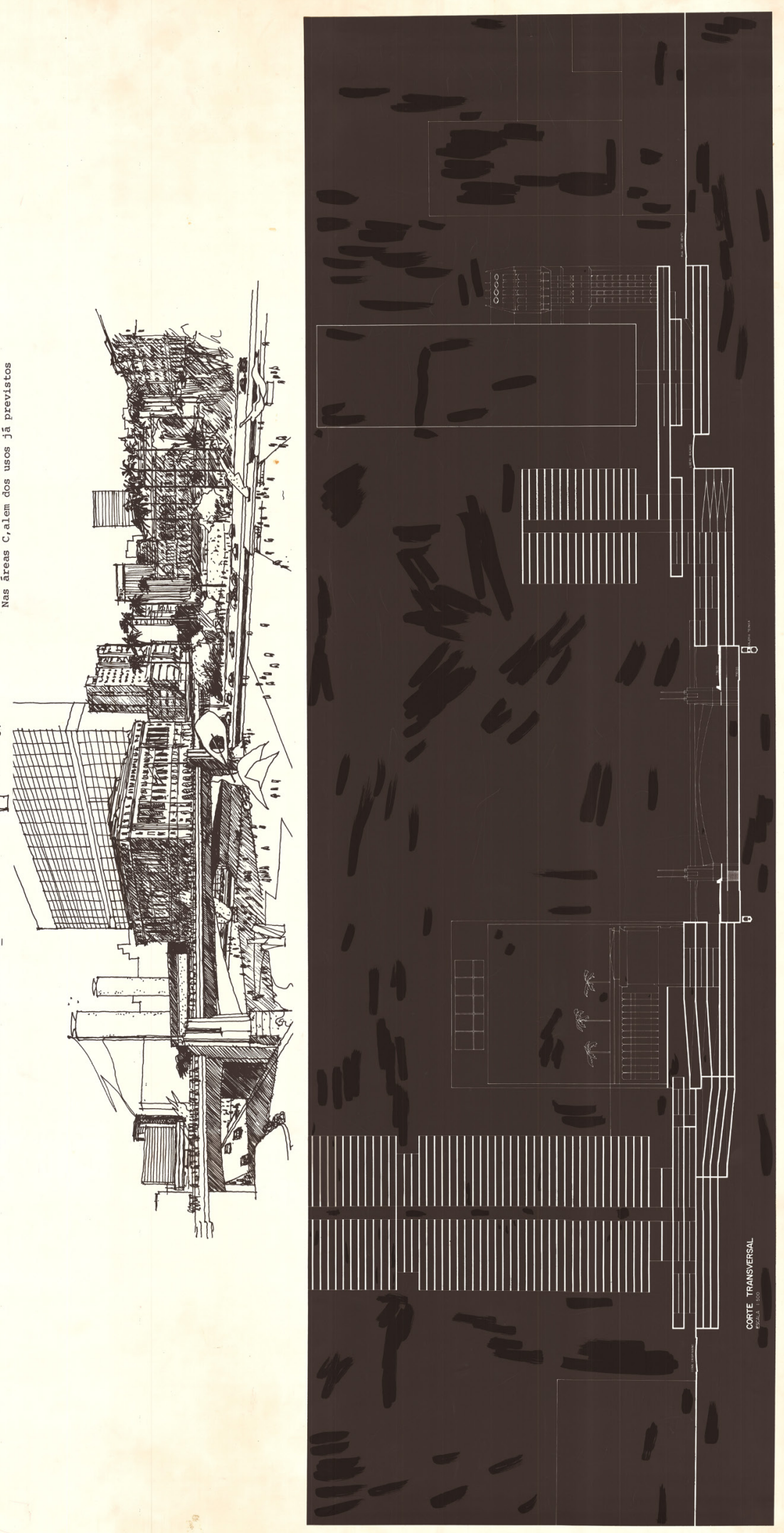

Pranchas do Concurso 


\section{Projeto 83 [menção honrosa]}

Autores:

Carlos Bratke - Arquiteto (São Paulo - SP)

Joaquim Cláudio de Oliveira Barreto - Arquiteto (São Paulo - SP)
Colaboradores:

Maria Luísa Giaroli de Oliveira Barreto - Socióloga

Luiz Domingues de Castro Filho - Arquiteto

José Carlos Caparica Olzon - Arquiteto

François Henri Louis Guerin - Projetista

Lídia Matiko Yamana - Arquiteta

Claudia Maria Lavieri Lapetina - Arquiteta

João Luís Marques - Projetista

Jorge M. Abussanra - Estagiário

Inês Cristina Santos Prette - Desenhista 


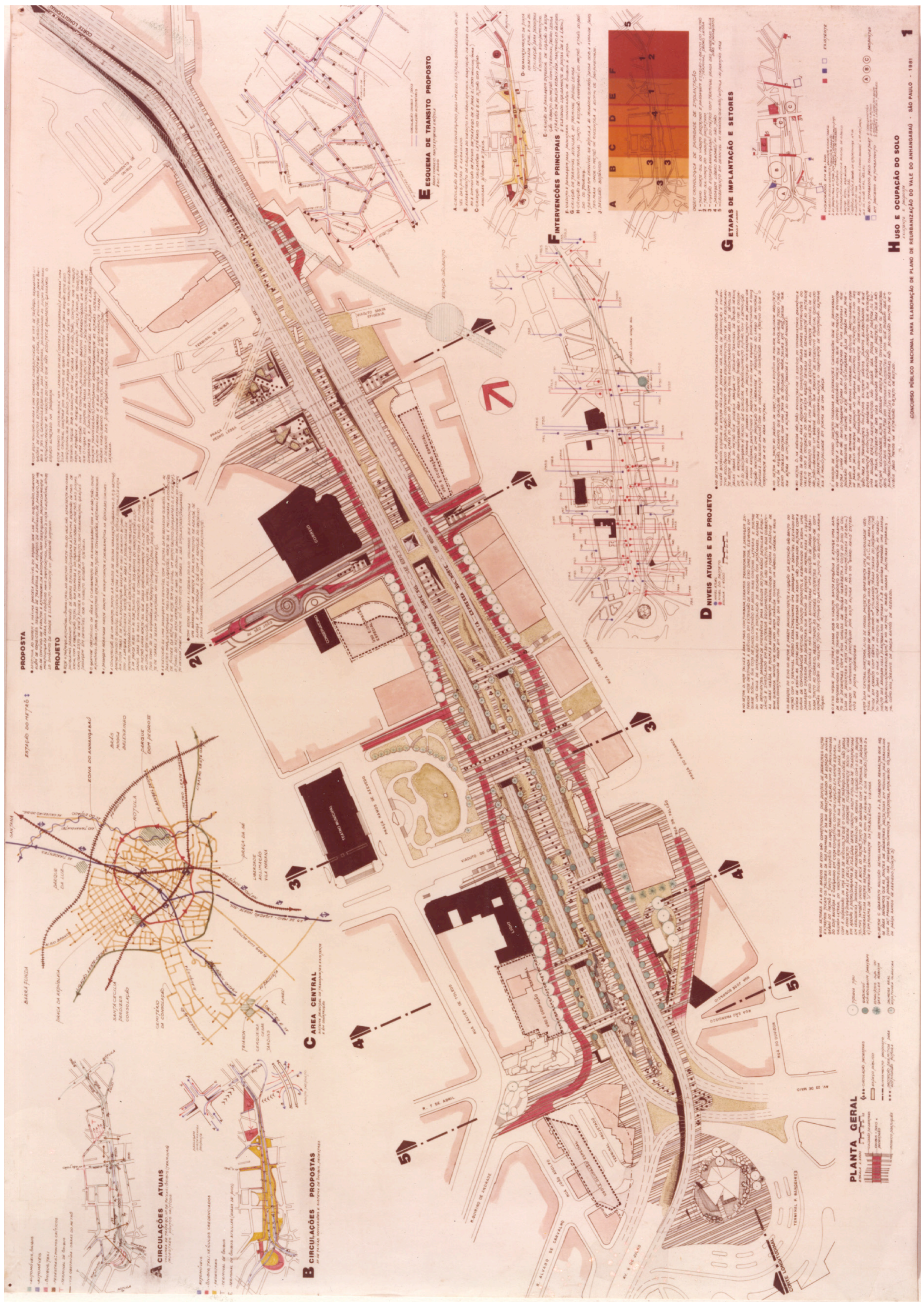




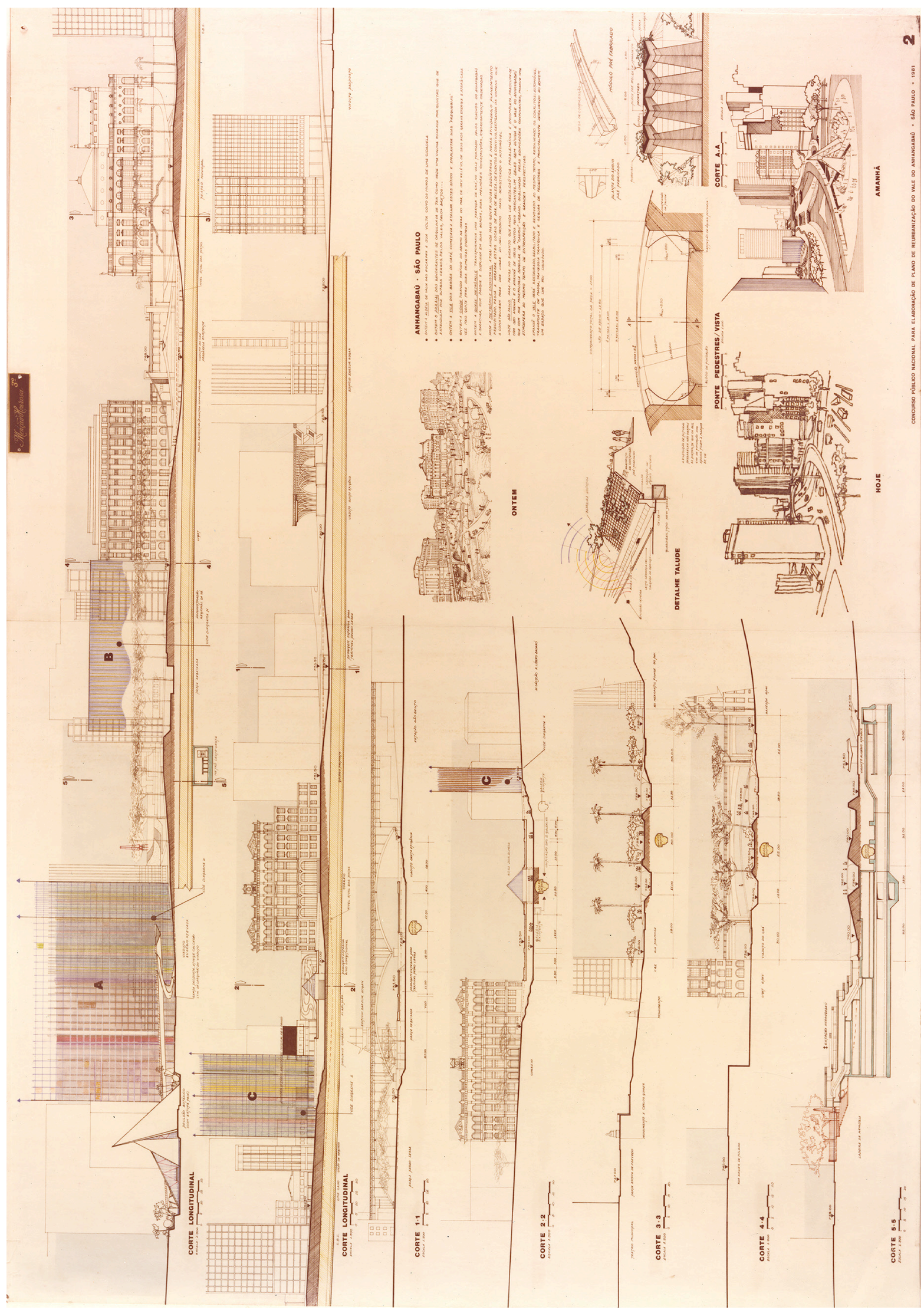




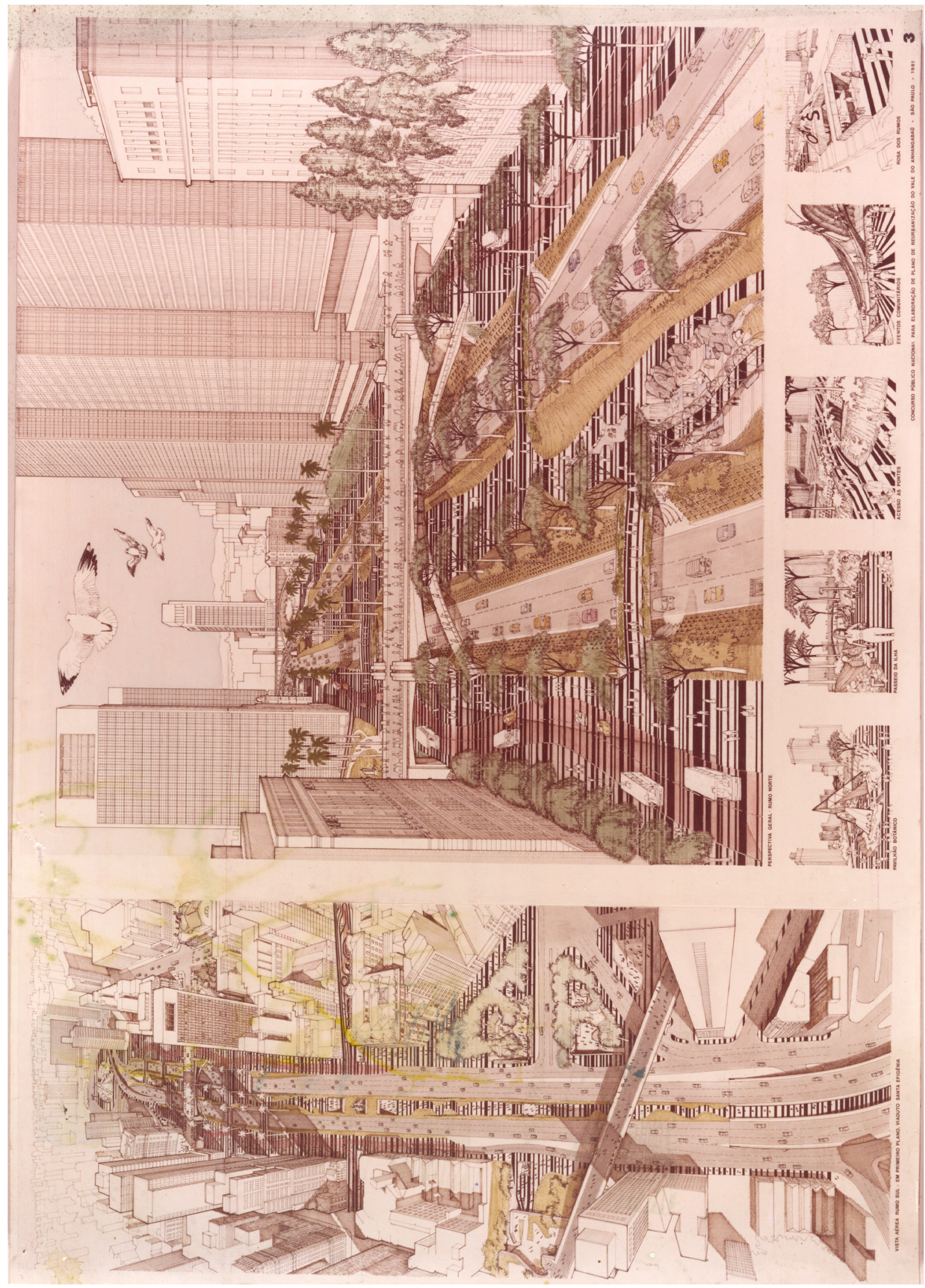




\section{Projeto 16 [ $3^{\circ}$ prêmio]}

Autores:

Paulo Bastos - Arquiteto (São Paulo - SP)

Siegbert Zanettini - Arquiteto (São Paulo - SP)
Colaboradores:

José Sales Costa Filho - Arquiteto

Newton Massafumi Yamamoto - Arquiteto

Maria de Fátima Araújo - Arquiteta

Roberto Israel Eisenberg Saruê - Arquiteto

Mirthes Ivany Soares Baffi - Arquiteto

Miriam Lobel - Arquiteta

Vanderlei Nunes Collange - Arquiteto

Antônio Brazão Rodrigues - Arquiteto

José Antônio Henrique - Arquiteto

Carlos David Nassi - Engenheiro / Transportes

Ana Lucia Brasil - Engenheira / Saneamento

Walter Vaccaro - Engenheiro / Ventilação

Aluísio Amaral Monteiro Leite - Engenheiro /

Custos

Luiz Morales Davila - Engenheiro / Técnica

Construtiva

Wagner Amodeo - Estagiário 


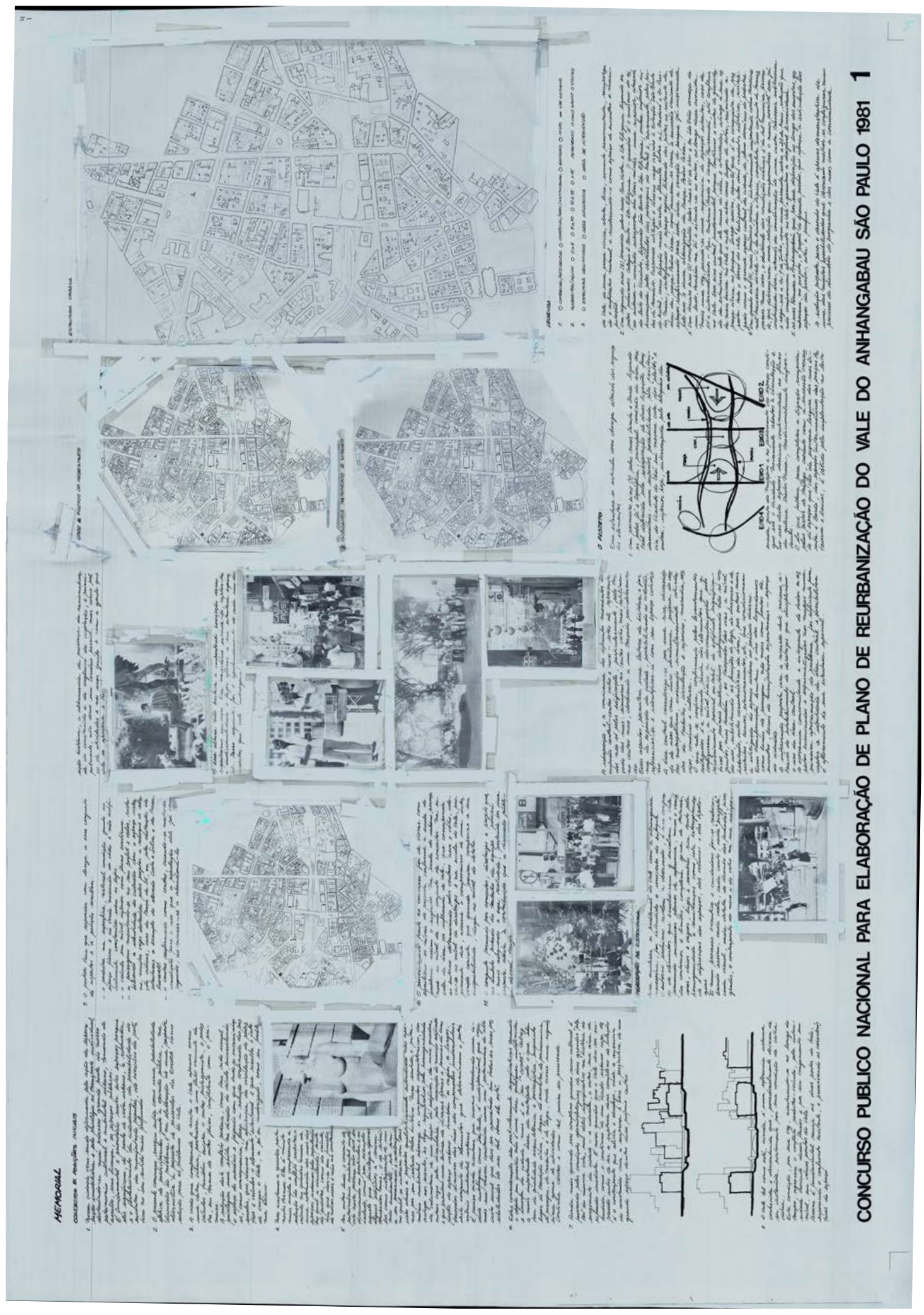




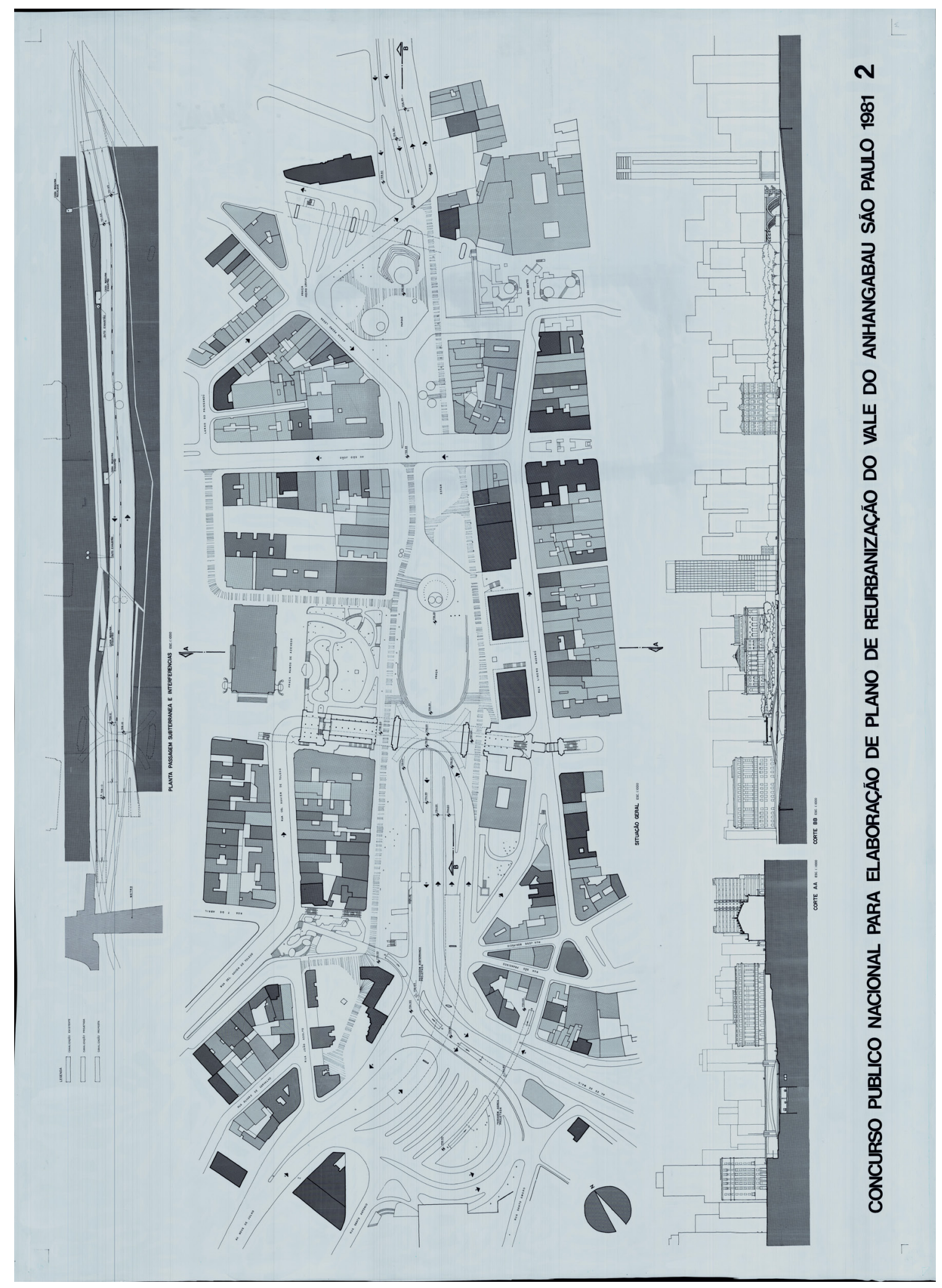




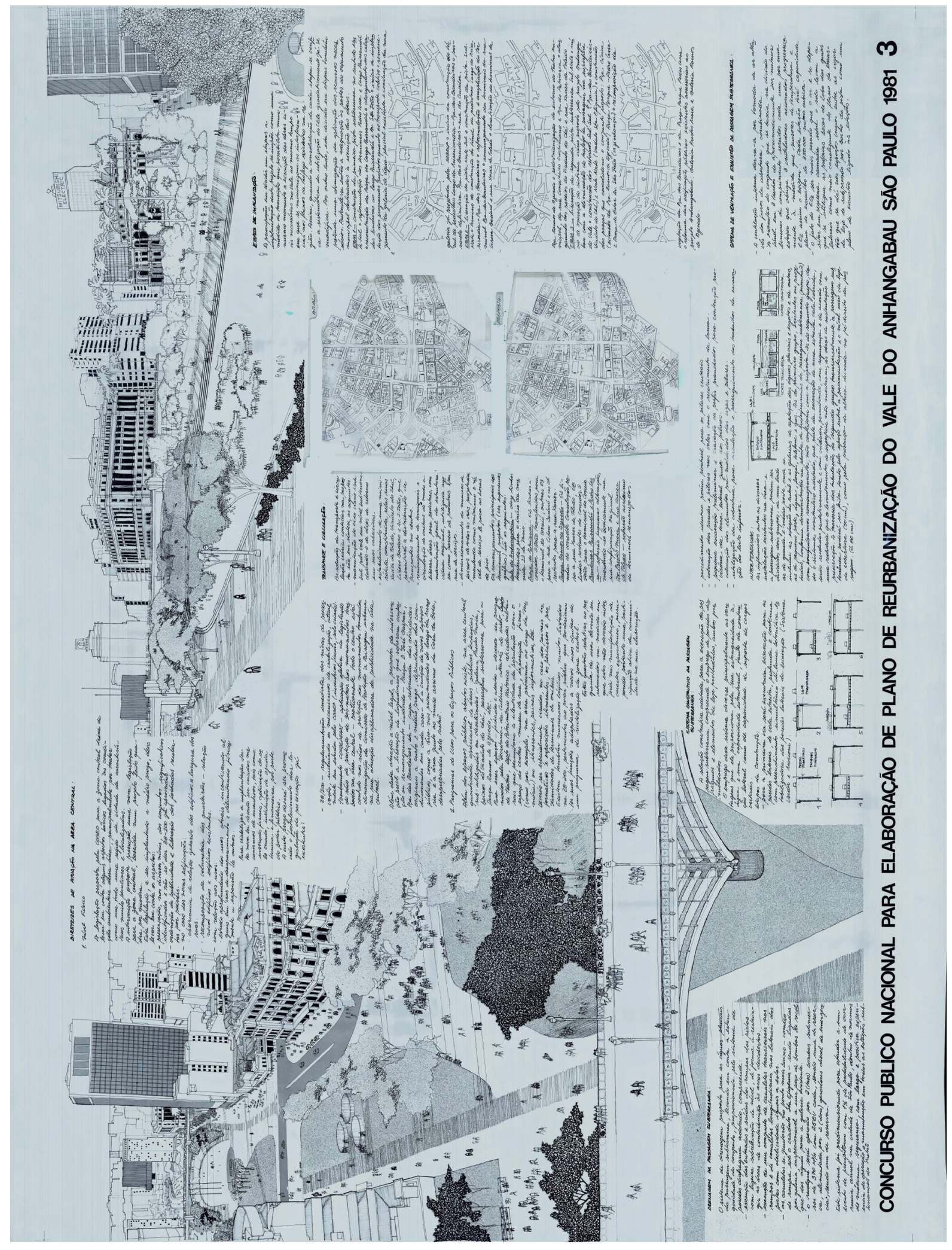

